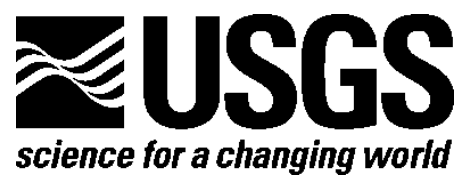

\title{
Geologic and Geophysical Maps of the El Casco 7.5' Quadrangle, Riverside County, Southern California, with Accompanying Geologic-Map Database
}

By J.C. Matti, D.M. Morton, and V.E. Langenheim

Pamphlet to accompany

Open-File Report 2010-1274

U.S. Department of the Interior

U.S. Geological Survey 


\section{U.S. Department of the Interior \\ SALLY JEWELL, Secretary}

\section{U.S. Geological Survey \\ Suzette M. Kimball, Acting Director}

U.S. Geological Survey, Reston, Virginia: 2015

For more information on the USGS-the Federal source for science about the Earth, its natural and living resources, natural hazards, and the environment-visit http://www.usgs.gov/ or call 1-888-ASK-USGS (1-888-275-8747).

For an overview of USGS information products, including maps, imagery, and publications, visit http://www.usgs.gov/pubprod/

To order USGS information products, visit http://store.usgs.gov/

Any use of trade, product, or firm names is for descriptive purposes only and does not imply endorsement by the U.S. Government.

Although this information product, for the most part, is in the public domain, it also may contain copyrighted materials as noted in the text. Permission to reproduce copyrighted items must be secured from the copyright owner.

Suggested citation:

Matti, J.C., Morton, D.M., and Langenheim, V.E., 2015, Geologic and geophysical maps of the El Casco 7.5' quadrangle, Riverside County, southern California, with accompanying geologic-map database: U.S. Geological Survey Open-File Report 2010-1274, 141 p., 3 sheets, scale 1:24,000, http://dx.doi.org/10.3133/ofr20101274.

ISSN 2331-1258 (online) 


\section{Contents}

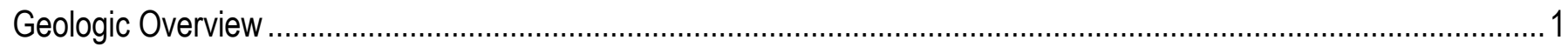

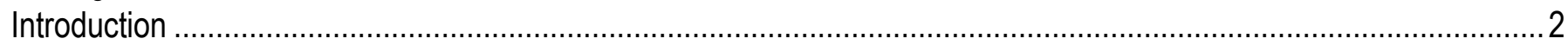

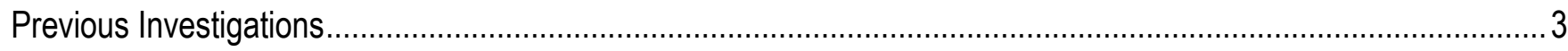

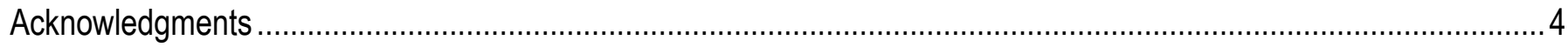

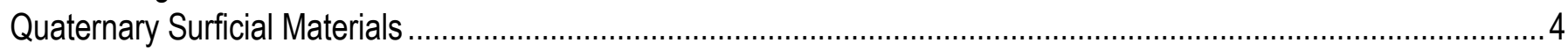

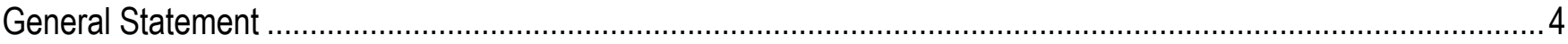

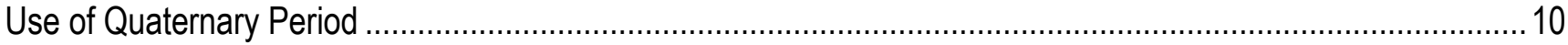

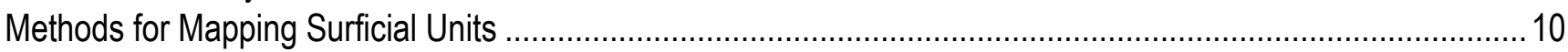

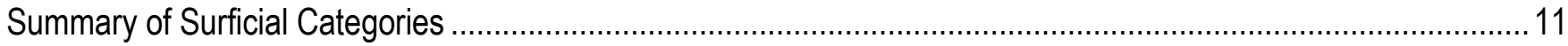

Very Young Deposits (Qvy Series) ......................................................................................................

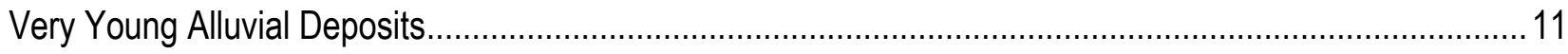

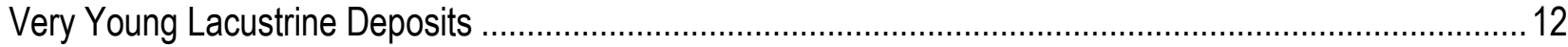

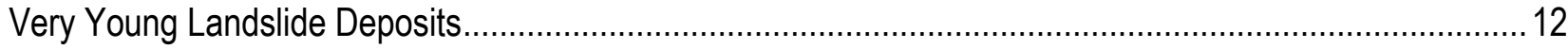

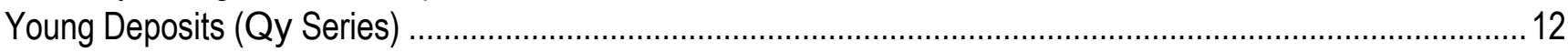

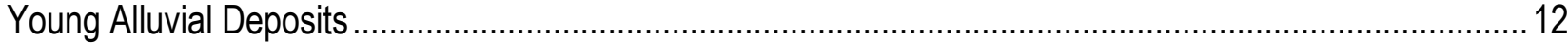

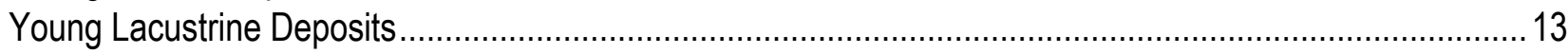

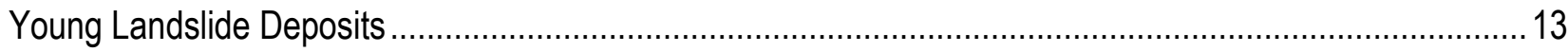

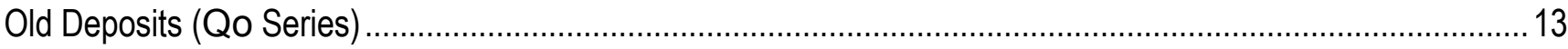

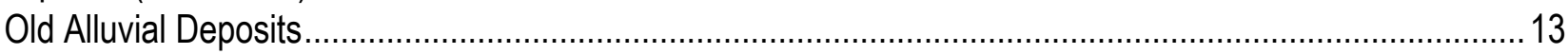

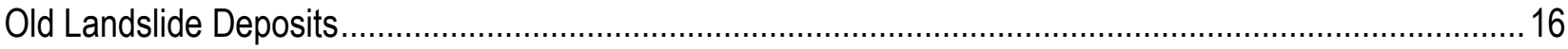

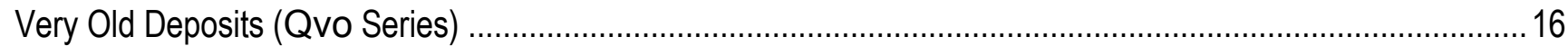

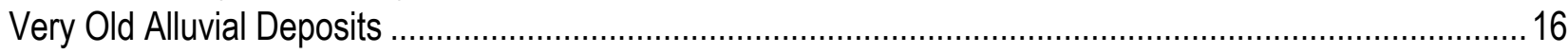

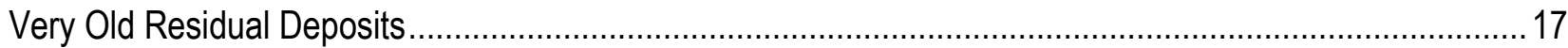

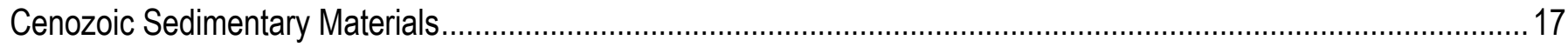

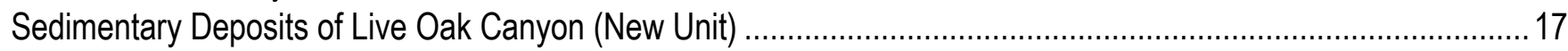

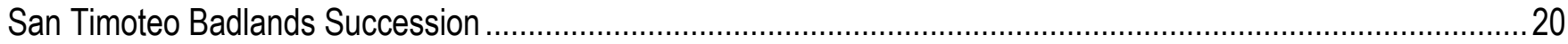

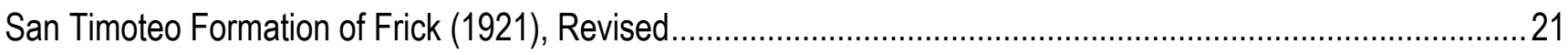

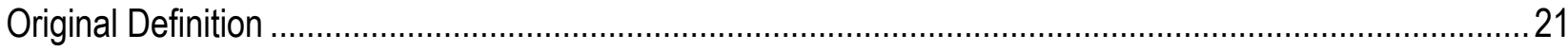

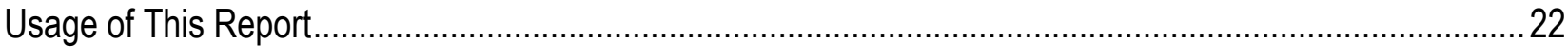

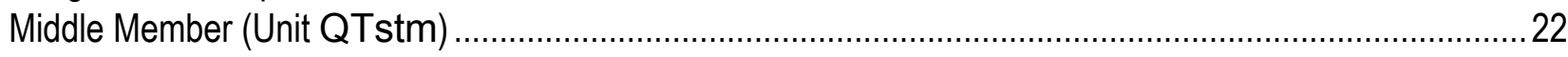

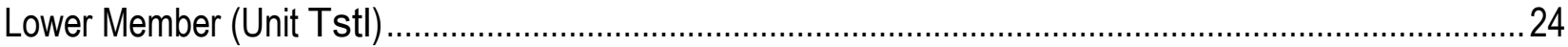

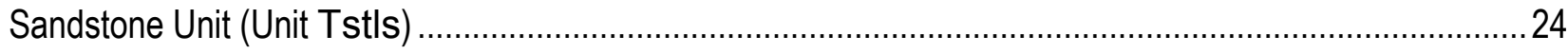

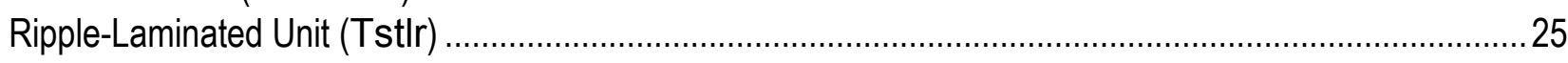

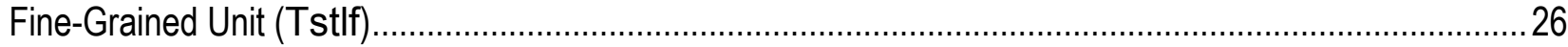

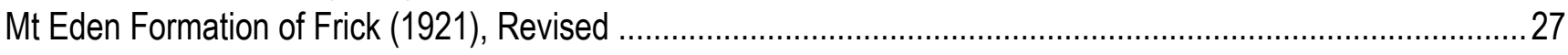

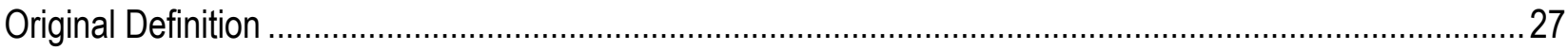

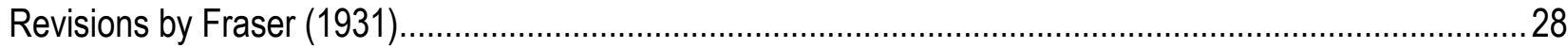

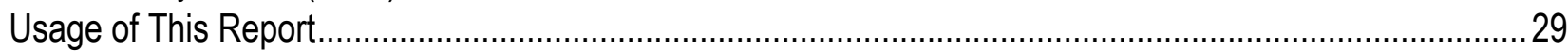

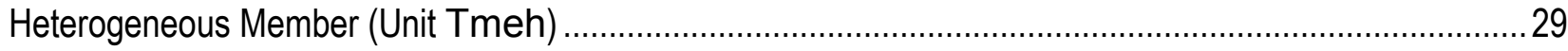

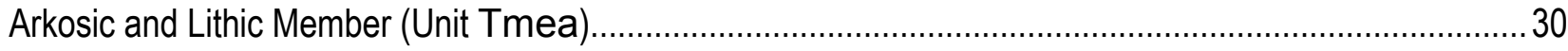

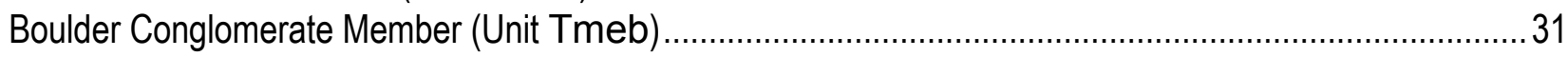

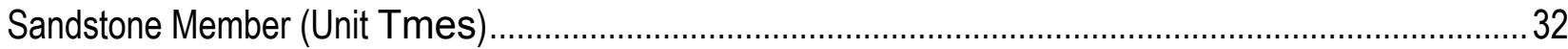

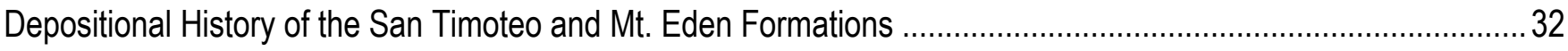

Depositional History, Mt. Eden Formation............................................................................................... 32 


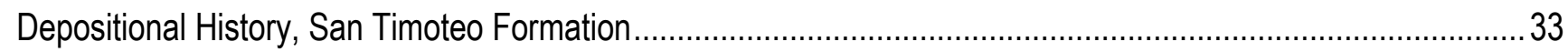

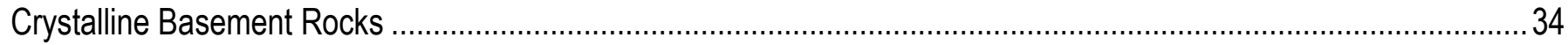

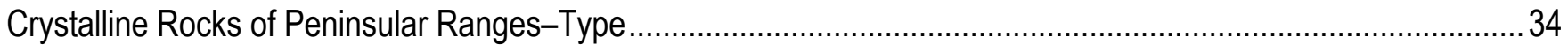

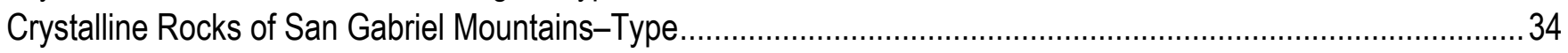

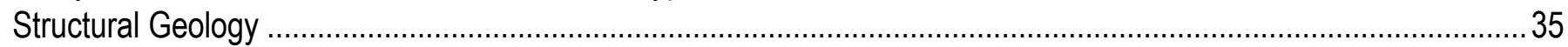

Folds

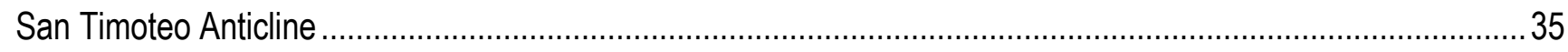

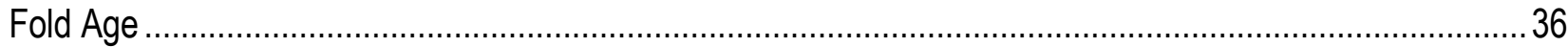

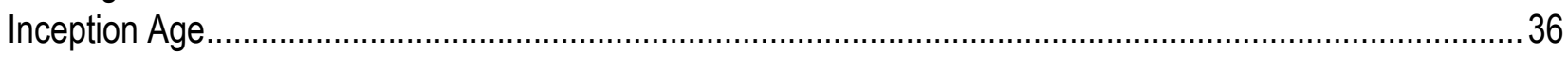

Folding Synchronous with Live Oak Canyon Deposition ....................................................................... 37

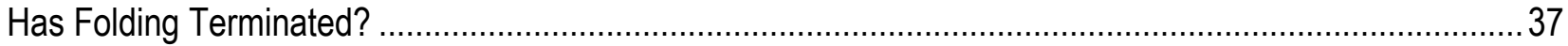

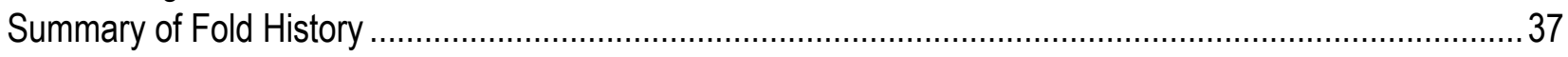

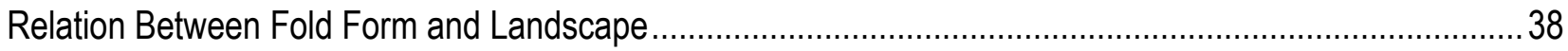

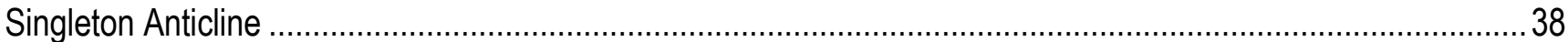

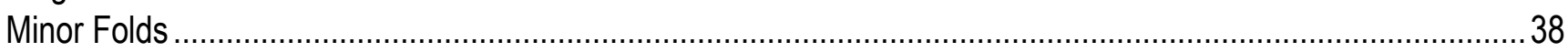

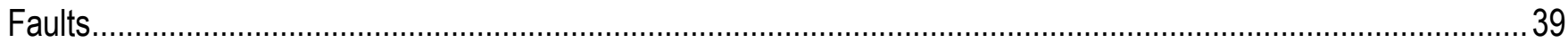

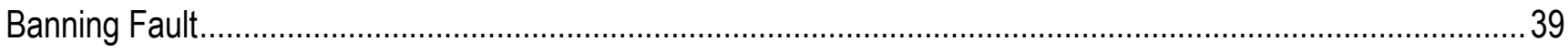

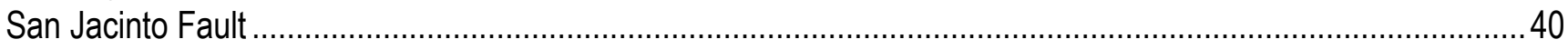

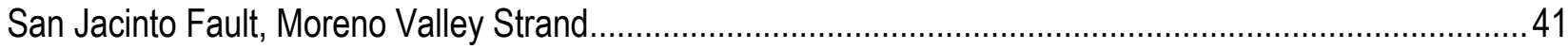

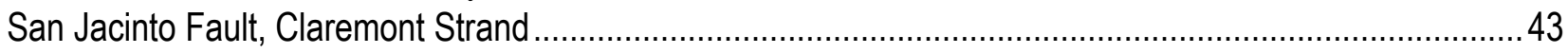

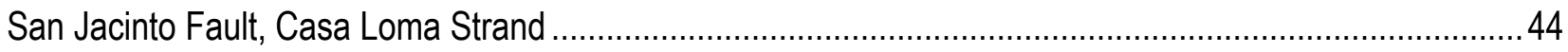

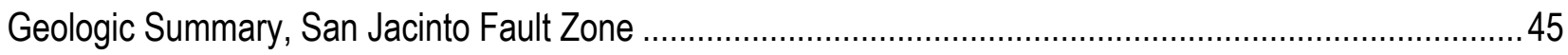

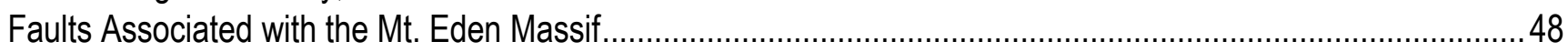

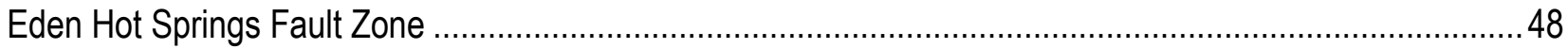

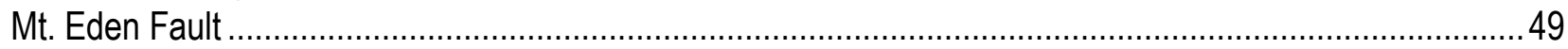

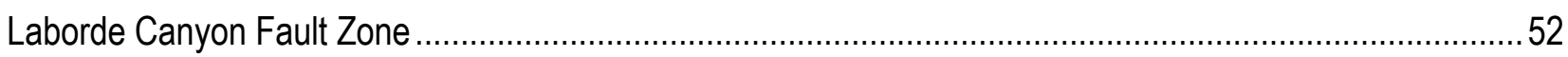

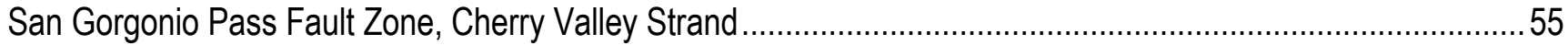

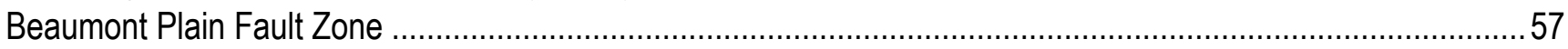

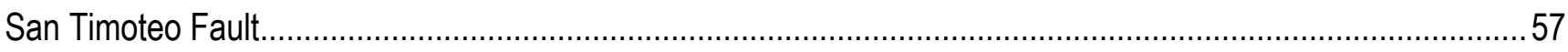

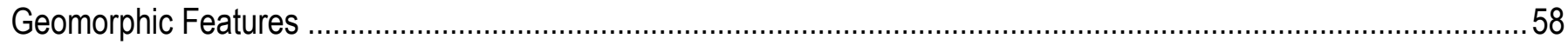

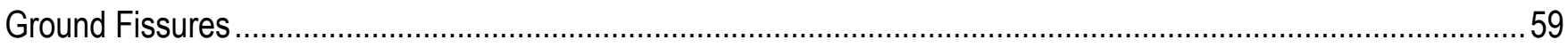

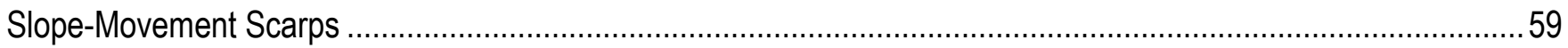

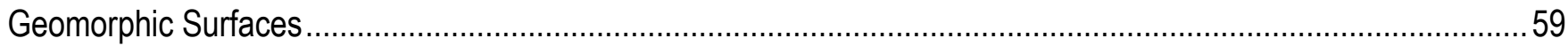

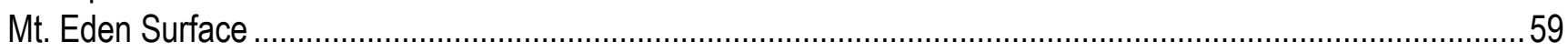

Relations Between Mt. Eden Surface and Other Landscapes..................................................................

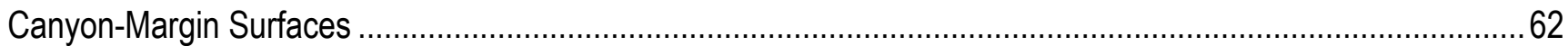

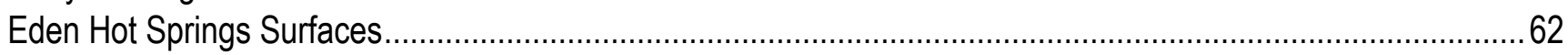

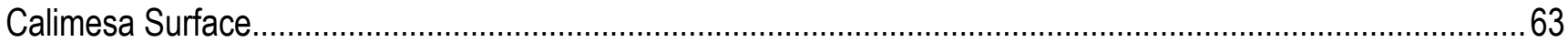

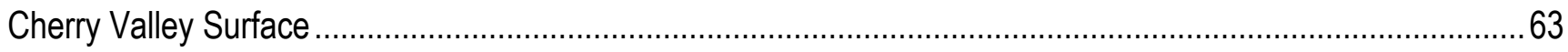

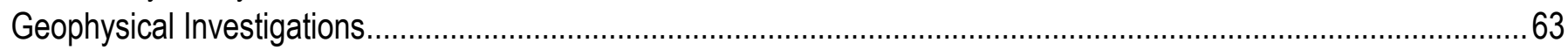

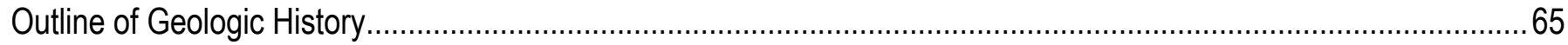

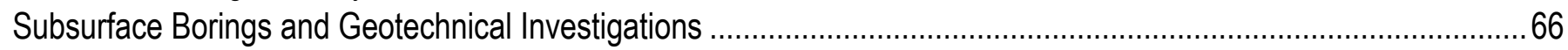

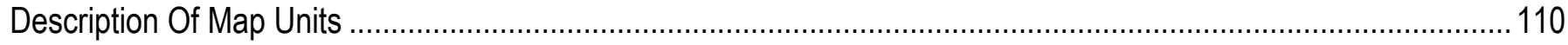

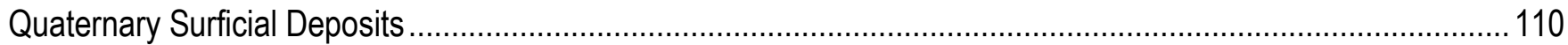

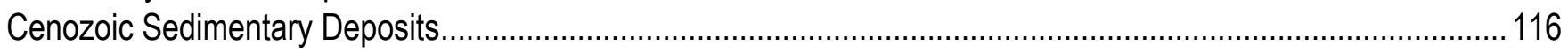




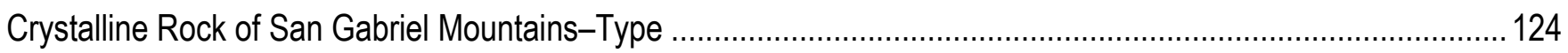

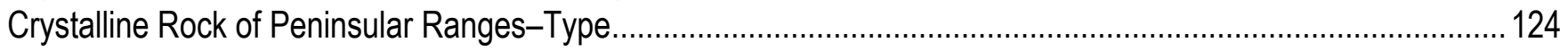

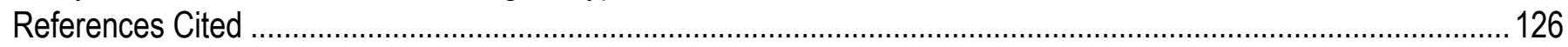

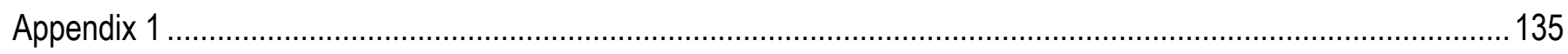

Boundary Between the San Timoteo and Mt. Eden Formations .................................................................. 135

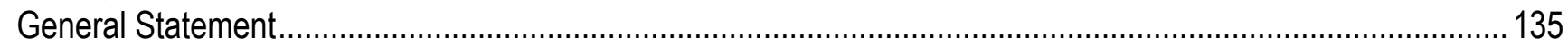

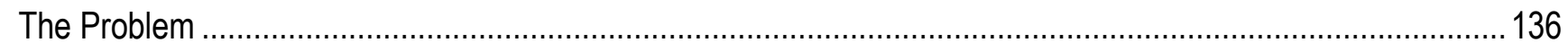

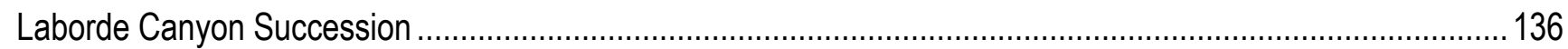

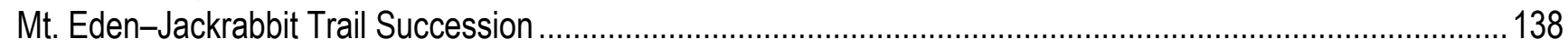

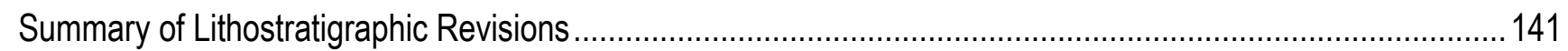

\section{Figures}

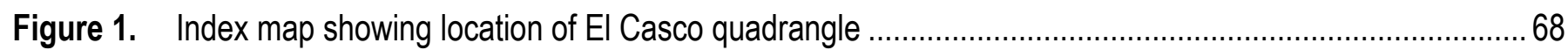

Figure 2. Map showing location of El Casco quadrangle relative to faults and basement-rock terranes in region... 69

Figure 3. Hierarchical classification of surficial materials for El Casco quadrangle and Inland Empire region

based on integration of materials genesis and geologic age ........................................................... 70

Figure 4. Chart showing relations among Quaternary time-rock divisions, marine oxygen-isotope stages, glacial events, and paleomagnetic chronology .....

Figure 5. Chart showing stratigraphic position of surficial geologic-map units mapped in this report (Qvy, Qy, Qo, Qvo) compared to alluvial-terrace units (T1-T9) and alluvial surfaces Q1-Q4b) defined by Bull

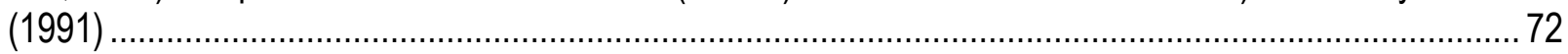

Figure 6. Chart showing stratigraphic position of surficial geologic-map units for uppermost Pleistocene and Holocene Series in El Casco quadrangle ................................................................................... 73

Figure 7. Diagram illustrating history of nomenclatural usage across boundary between the San Timoteo formation of Frick (1921) and the Mt. Eden Formation of Frick (1921) ...

Figure 8. Diagram showing late Cenozoic stratigraphic relations between San Timoteo Badlands region (left side of diagram) and San Gorgonio Pass region (right side of diagram) ................................................... 75

Figure 9. Photograph of the sedimentary deposits of Live Oak Canyon ..........................................................76

Figure 10. Typical bedding and fabric characteristics of ledge-forming conglomeratic beds in the sedimentary

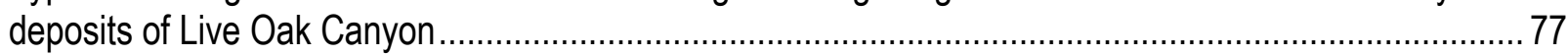

Figure 11. View looking north at white-colored rocks of San Timoteo formation (center middle ground) surrounded by brownish-colored beds of the sedimentary deposits of Live Oak Canyon...

Figure 12. Stratigraphic relations between the sedimentary deposits of Live Oak Canyon (Qlo) and middle member of the San Timoteo formation of Frick (1921) (QTstm) ..................................................... 79

Figure 13. View looking northwest from San Jacinto 7.5' quadrangle toward San Timoteo Badlands ........................80

Figure 14. Middle member of San Timoteo formation (unit QTstm) ............................................................ 81

Figure 15. Details of conglomeratic rock in middle member of San Timoteo formation (unit QTstm) in roadcut of Jackrabbit Trail

Figure 16. Lower member of San Timoteo formation, sandstone unit (Tstls)..................................................... 83

Figure 17. Lower member of San Timoteo formation, sandstone unit (Tstls) .................................................. 84

Figure 18. Ripple-laminated unit (Tstlr) of lower member, San Timoteo formation in roadcut of Jackrabbit Trail..... 85

Figure 19. Lithologic details and sedimentary structures, ripple-laminated unit (Tstlr) of San Timoteo formation lower member in roadcut of Jackrabbit Trail.

Figure 20. Lithologic details and sedimentary structures, ripple-laminated unit (Tstlr) of San Timoteo formation lower member; roadcut of Jackrabbit Trail..

Figure 21. Lithologic and structural details, ripple-laminated member of the San Timoteo formation (unit Tstlr) in roadcut of Jackrabbit Trail 
Figure 22. Boundary interval between the Mt. Eden formation of Frick (1921) (slope-forming unit in foreground) and the San Timoteo formation of Frick (1921) (more ledgy unit in middle ground) in vicinity of lower Lamb Canyon

Figure 23. Boundary interval between the Mt. Eden formation of Frick (1921) (greenish-gray slopes in foreground) and the San Timoteo formation of Frick (1921) (ledgy rocks in upper part of outcrop) in vicinity of lower

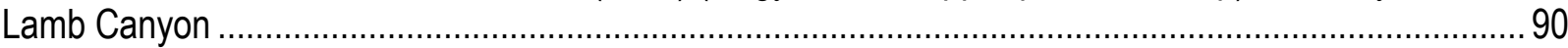

Figure 24. Heterogeneous member of the Mt. Eden formation (unit Tmeh) in roadcut of Jackrabbit Trail ............... 91

Figure 25. Heterogeneous member of the Mt. Eden formation (unit Tmeh) in roadcut of Jackrabbit Trail ............... 92

Figure 26. Heterogeneous member of the Mt. Eden formation (unit Tmeh) in roadcut of Jackrabbit Trail, close to boundary with underlying lithic and arkosic unit (Tmea) ............................................................... 93

Figure 27. Arkosic and lithic member of the Mt. Eden formation (unit Tmea) along access road to Eden Hot Springs

Figure 28. Arkosic and lithic member of the Mt. Eden formation (unit Tmea) along access road to Eden Hot

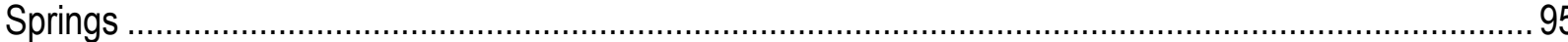

Figure 29. Details of arkosic and lithic member of the Mt. Eden formation (unit Tmea) in roadcut of Jackrabbit Trail

Figure 30. Details of arkosic and lithic member of the Mt. Eden formation (unit Tmea) in roadcut of Jackrabbit Trail .....

Figure 31. Boulder conglomerate member of the Mt. Eden formation (unit Tmeb) in lower Lamb Canyon.............. 98

Figure 32. Google Earth ${ }^{\odot}$ image looking east-northeast toward Mt. Eden massif (ME), showing various faults we map in Mt. Eden area.

Figure 33. Google Earth ${ }^{\odot}$ image looking southeast toward Mt. Eden massif (ME), showing various faults we map in Mt. Eden area

Figure 34. Google Earth ${ }^{\odot}$ image looking north toward Mt. Eden massif (ME), showing faults we map in Mt. Eden area.....

Figure 35. Google Earth ${ }^{\odot}$ image looking east-southeast toward Mt. Eden massif (ME), showing Mt. Eden surface (red short-dashed line) and faults we map in Mt. Eden area ........................................................... 102

Figure 36. View looking northwest at Laborde Canyon Fault on north slope of Mt. Eden ..................................... 103

Figure 37. Close-up view of Laborde Canyon Fault shown in figure 36 ........................................................... 104

Figure 38. View of Cherry Valley Fault, showing topographic scarp and trench excavated by Petra Consultants (2004)

Figure 39. Closer view of trench exposures of figure 38

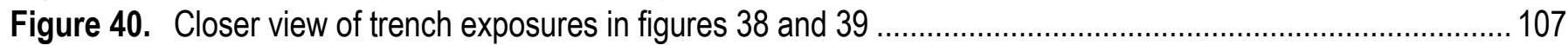

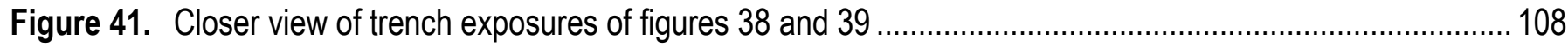

Figure 42. Map of isostatic gravity for El Casco 7.5' quadrangle (derived from map sheet 3 of 3 ). White lines are faults

Tables

Table 1. Terms for degree of consolidation in surficial materials, together with threshold definitions (modified from table 13.2.6.1 in North American Geologic-map Data Model Sedimentary Science Language Technical Team, 2004, p. 87, which cites Bowles, 1984, p. 151-152).

Table 2. Time-stratigraphic intervals (Qvy, Qy, Qo, Qvo) recognized in Inland Empire region of southern California; also see figure 5 .

Table 3. Possible scenarios for evolution of Mt. Eden surface in El Casco quadrangle. ........................................60

Table 4. Outline of geologic events affecting map units in El Casco quadrangle................................................. 65

Table 5. Listing of deep exploratory subsurface borings drilled in greater San Timoteo Badlands area (derived from Shuler, 1953, p. 78). 


\title{
Geologic and Geophysical Maps of the El Casco 7.5' Quadrangle, Riverside County, Southern California, with Accompanying Geologic-Map Database
}

\author{
By J.C. Matti, D.M. Morton, and V.E. Langenheim
}

\section{Geologic Overview}

The El Casco 7.5' quadrangle is located in a geologic region where contractional deformation in the San Gorgonio Pass area of southern California gives way westward to transtensional deformation associated with the right-lateral San Jacinto Fault zone (figs. 1, fig. 2).

The El Casco quadrangle is traversed by several important fault zones, including: (1) the Banning Fault, a late Miocene fault that once formed a strike-slip strand of the right-lateral San Andreas system and since has been the locus of periodic contractional reactivation; (2) several strands of the Quaternary San Jacinto Fault zone, a northwest-trending right-lateral strike-slip fault zone that is an important component of the modern San Andreas transform-fault system in southern California. The San Jacinto strands occur in the southwest corner of the quadrangle, where they form a complex series of en echelon faults that have contributed to growth and subsidence of the San Jacinto Valley graben; (3) the Cherry Valley Fault, a middle to late Quaternary thrust fault that is the westernmost projection of the San Gorgonio Pass Fault zone; (4) the San Timoteo Fault, a previously unrecognized northwest-trending normal dip-slip fault beneath the San Timoteo drainage system that played an important role in the deposition of lower and middle Quaternary deposits north of the San Timoteo Badlands; and (5) the Beaumont Plain Fault zone, a northwest-trending normal-slip fault complex in the northeast corner of the quadrangle that forms east- and west-facing scarps in upper Quaternary alluvial deposits.

Crystalline basement rocks underlie all of the quadrangle, but are exposed only in two areas: (1) in the northeast corner of the quadrangle, north of the Banning Fault (rocks of Transverse Ranges-type); and (2) in the south part of the quadrangle (rocks of Peninsular Ranges-type); these presumably extend in the subsurface north to the Banning Fault, which is thought to separate the two regionally extensive basement suites (fig. 2; Matti and others, 1992a).

Much of the El Casco quadrangle is underlain by sedimentary materials that are late Miocene to middle Pleistocene in age. These crop out in the San Timoteo Badlands and in low hills north of San Timoteo Canyon. The deposits accumulated during a period of sedimentation that began in late Miocene time (probably about 7 or 8 million years ago) and continued into the middle Pleistocene ( $\sim 00 \mathrm{ka})$. In the Badlands, older parts of these deposits are deformed into a major anticlinal fold (San Timoteo Anticline) that for much of its length plunges gently to the northwest. Due to this gentle plunge, older strata in the sequence crop out in the southeastern part of the El Casco quadrangle, whereas progressively younger strata crop out to the northwest.

The late Miocene to middle Pleistocene sedimentary sequence is divided into three major map units: (1) the Mt. Eden formation and (2) the overlying San Timoteo formation, both defined originally by Frick (1921), and (3) the sedimentary deposits of Live Oak Canyon, newly introduced in this report. Sandy and conglomeratic sediment in the Mt. Eden formation was derived from local Peninsular Ranges sources and deposited in alluvial environments adjacent to those sources; mudrock and limestone represent playa and lacustrine deposits. Muddy, sandy, and conglomeratic sediment in the San Timoteo formation was derived from San Gabriel Mountains-type sources north of the El Casco quadrangle and 
shed south and southeast onto the Peninsular Ranges landscape; the transition between the Mt. Eden and San Timoteo depositional cycles thus represents an important paleogeographic shift in the Inland Empire region of southern California. Ultimately, inselbergs of Peninsular Ranges rock in the El Casco quadrangle were completely buried by sediment of the San Timoteo formation; the inselbergs currently are being exhumed and re-exposed. The San Timoteo depositional regime terminated about 1.2 Ma with inception of the San Jacinto Fault, and was succeeded by deposition of sandy and conglomeratic sediment of Live Oak Canyon that accumulated in alluvial environments ponded north of a growing ridge that developed in the San Timoteo Badlands.

Quaternary surficial deposits occur locally throughout the El Casco quadrangle, but are extensive in two main areas: (1) the San Jacinto Valley in the southwest part of the quadrangle and (2) the San Timoteo Creek drainage basin in the north part of the quadrangle. In San Jacinto Valley, surficial deposits form a thick fill of muddy and sandy sediment deposited mainly by alluvial fans that head north and northeast into canyons dissecting the San Timoteo Badlands. The alluvial-fan deposits interfinger with overbank alluvial and lacustrine deposits of the San Jacinto River system (fig. 1). In the north part of the quadrangle, San Timoteo Creek and its distributaries form a long-lived fluvial system that has evolved over the last several hundred thousand years. This system has been the site of repeated dissection and alluvial aggradation-geomorphic cycles that alternately have eroded the landscape into valleys and ridges and then back-filled the valleys with multiple alluvial-fan and axial-valley sequences. The latter periodically have filled tributary valleys and buttressed unconformably against landforms developed on the San Timoteo formation of Frick (1921). Throughout middle and late Quaternary time, the San Jacinto and San Timoteo Creek depositional systems have evolved independently from one another, separated by high ground formed by the San Timoteo Badlands.

Late Cenozoic depositional and structural events within the El Casco quadrangle provide insight into the evolution of the San Andreas Fault system. The San Timoteo formation of Frick (1921) records a long-lived period when alluvial-fan and braidplain sediments derived from basement rocks of San Gabriel Mountains-type encroached southeastward and southward onto a landscape underlain mainly by crystalline rocks of Peninsular Ranges-type. This paleogeographic regime persisted until about 1.2-1.5 million years, when the regime was disrupted by inception of the San Timoteo Anticline and initiation of new depositional patterns within the San Timoteo sedimentary sequence. The new regime developed north of the San Timoteo Badlands, within a synformal depositional basin that formed in association with the San Timoteo Anticline to the south; basin formation appears to have been facilitated by downto-the-north normal-slip displacements on the San Timoteo Fault. Sediment that formed in this basin buttressed unconformably against older beds of the San Timoteo sequence that were being arched by the San Timoteo Anticline into a higher standing landscape. The syntectonic sedimentary sequence locally exceeds $366 \mathrm{~m}$ (1,200 ft) in thickness, but mainly is concealed beneath upper Quaternary deposits of the Beaumont Plain. These syntectonic deposits are more permeable than the San Timoteo sequence, and form an extensive groundwater reservoir. All of these sedimentary and structural events are associated with the inception and movement history of the San Jacinto Fault zone.

\section{Introduction}

Earth materials and structures in the El Casco quadrangle provide considerable information about the late Cenozoic geologic evolution of southern California's Inland Empire region (fig. 2). Important structural and stratigraphic elements include (1) modern traces of the right-lateral San Jacinto Fault zone, (2) older traces of the San Jacinto Fault zone, and (3) sedimentary materials and geologic structures that formed during the last eight million years or so and that record interactions within the San Andreas Fault system. These materials, and the structures that deform them, provide a geologic context 
for investigations of groundwater recharge and subsurface flow (Waring, 1919; Burnham and Dutcher, 1960; Bloyd, 1971; Rewis and others, 2006).

This geologic database of the El Casco 7.5' quadrangle was prepared by the Basins and Landscape Co-Evolution Project (BALANCE), a regional geologic-mapping project sponsored jointly by the U.S. Geological Survey and the California Geological Survey. The database was developed as a contribution to the National Cooperative Geologic Mapping Program's National Geologic Map Database, and provides a general geologic setting of the El Casco quadrangle. The database and map provide information about earth materials and geologic structures, including faults and folds that have developed in the quadrangle due to complexities in the San Andreas Fault system.

Geologic information contained in the El Casco database is general-purpose data applicable to land-related investigations in the earth and biological sciences. The term "general-purpose" means that all geologic-feature classes have minimal information content adequate to characterize their general geologic characteristics and to interpret their general geologic history. However, no single feature class has enough information to definitively characterize its properties and origin. For this reason the database cannot be used for site-specific geologic evaluations, although it can be used to plan and guide investigations at the site-specific level.

\section{Previous Investigations}

In an early hydrogeologic investigation of the greater San Bernardino Valley region, Mendenhall (1905, p. 68) briefly discussed sedimentary materials of the San Timoteo Badlands (his "older alluvium"), and provided a simplified geologic section that spanned the Badlands near the northwest corner of the El Casco quadrangle. Following a series of earthquakes in the San Jacinto Valley region in the late $19^{\text {th }}$ and early $20^{\text {th }}$ Centuries, various workers discussed the San Jacinto Fault along the southwest edge of the San Timoteo Badlands (Arnold, 1918; Hamlin, 1918; Rolfe and Strong, 1918; Townley, 1918). In his study of groundwater in the San Jacinto Valley region, Waring (1919, p. 9) briefly described the geology of the San Timoteo Badlands, and discussed the chemistry and temperature of hot springs in the Mt. Eden area of the El Casco quadrangle (Waring, 1919, p. 11). Frick (1921) provided the first stratigraphic classification of sedimentary materials in the San Timoteo Badlands, and described fossil vertebrates he collected from the Mt. Eden area. Fraser (1931) mapped the San Jacinto quadrangle southeast of the map area, including sedimentary materials that extend into the El Casco quadrangle. As part of his study of South Coastal hydrogeologic basins, Eckis (1934) briefly discussed geologic and hydrologic relations in the San Timoteo Badlands region. Dudley (1936) referred to the San Timoteo Badlands sedimentary succession in his discussion of the geomorphology and physiography of the Perris block. Axelrod (1937) described fossil plants collected in the Mt. Eden area studied previously by Frick (1921). Unpublished undergraduate theses have been conducted in the Mt. Eden area (Beyer, 1959; Blacet, 1960; MacLeod, 1961), and three graduate theses in the 1950s and 1960s investigated the stratigraphy and structure of the San Timoteo Badlands, including rocks and geologic structures in the El Casco quadrangle (English, 1953; Shuler, 1953; Larsen, 1962). Burnham and Dutcher (1960) described the geology and hydrogeology of the region mainly north of San Timoteo Canyon, but some of their observations are applicable to the El Casco quadrangle.

More recently, Fett (1968) conducted a geophysical investigation of the San Jacinto Valley region, mainly south of the El Casco quadrangle. Knecht (1971) mapped pedogenic soils in the El Casco quadrangle as part of a regional soils-mapping investigation of western Riverside County; soils in the San Bernardino County part of the quadrangle were mapped by Woodruff and Brock (1980). Sharp (1972) mapped geologic and geomorphic features associated with strands of the San Jacinto Fault. Morton (1972) mapped the geology of the Lakeview quadrangle directly south of the El Casco quadrangle, and later (Morton, 1977) examined geomorphic and structural features associated with rapid 
subsidence of the San Jacinto Valley. Land subsidence in the San Jacinto Valley also has been discussed by Lofgren and Meyer (1975) and by Lofgren (1976). Recent paleontologic investigations in the El Casco quadrangle and in the greater San Timoteo Badlands region include those by May and Repenning (1982), Reynolds and Reeder (1986, 1991), and Albright (1997, 1999). The paleontologic investigations have been integrated with magnetostratigraphic studies (Hehn and others, 1996; Albright, 1999).

Seismic-imaging investigations were conducted in the El Casco quadrangle (Park and others, 1995) and in the southern San Jacinto Valley (Lee and others, 1996) in order to clarify the distribution of strands of the San Jacinto Fault zone. Sanders and Magistrale (1997) examined seismic evidence for segmentation of the northern San Jacinto Fault zone. Regional seismicity has been evaluated by Hauksson (2000) and by Magistrale and others (2000)). Langenheim and others (2004) discussed geophysical and isotopic evidence for the origin of the San Jacinto Fault zone.

\section{Acknowledgments}

Geologic mapping for this study was sponsored by two U.S. Geological Survey (USGS) programs: the National Cooperative Geologic Mapping Program and the Earthquake Hazards Program. The mapping was coordinated with the California Geological Survey. Digitization of version 1.0 was cost-shared with the San Gorgonio Pass Water Agency and the U.S. Forest Service (San Bernardino National Forest). The U.S. Geological Survey’s Photogrammetric Plotter Laboratory in Denver, Colorado (James Messerich, photogrammetrist) provided Kern PG-2 stereographic plotters that enabled high-precision, high-accuracy transfer of geologic linework and point data from aerial photographs to a scale-stable cartographic base. A.H. Christensen (USGS) kindly provided an ArcGIS file of water-well locations in the El Casco quadrangle derived from USGS Water Resources data. Mr. Mark Knorringa of Oak Valley Partners, L.P., kindly granted access to lands under development by them north of San Timoteo Canyon. Jay Martin of CHJ, Inc., kindly loaned us a digital version of the image in figure 12. The map and report benefited from technical reviews by W.A. Reeder (San Bernardino County Geologist), G. Saucedo (California Geological Survey), and G. Treiman (California Geological Survey); the digital database was reviewed by E. Thoms (USGS).

\section{Quaternary Surficial Materials}

\section{General Statement}

Quaternary surficial materials - geologic materials that have accumulated at the land surface over the last 750,000 years or so - are widespread throughout the El Casco quadrangle. These are mainly unconsolidated materials that locally mantle the surface of hillslopes and that form the uppermost fillings of valleys and alluvial fans.

The boundary between sediment and sedimentary rock is not widely agreed to. The North American Geologic-map Data Model Sedimentary Science Language Technical Team (2004, p. 28-29, 86-89) provided the following discussion and guidelines:

"The transition between 'unconsolidated' and 'lithified' is not easy to define. In general, sedimentary materials that have begun to lithify will have some degree of cementation and (or) compaction that yields a stiff, firm, or coherent mass that resists breakage. This consolidation process leads to decreased pore space and increased relative density. The consolidation (lithification) process is influenced by sediment grain size, sorting, cohesiveness (cohesionless materials versus cohesive materials), overburden load, and circulating fluids. With increased consolidation, lithification and progressive hardening (induration) results, along with increase in relative density $* * *$. 
Recently deposited sediment is converted into consolidated rock that progressively hardens into indurated rock through a continuum of processes that include reduction of pore space through particle packing, rearrangement of sedimentary particles, deformation and flattening of particles under overburden loads, and chemical precipitation of cement that binds particles together. [text-fig. 1] illustrates schematically the sequence of consolidation and induration states that accompany these processes, and [table 1] defines science concepts associated with consolidation and induration.

Distinction between "unconsolidated" and "consolidated" sedimentary materials is blurred even more if weathering is introduced into the equation: even well cemented and indurated sedimentary rock may become friable due to intense weathering. Thus, weathered sedimentary rock that is friable needs to be distinguished conceptually from unconsolidated sediment $* * *$.
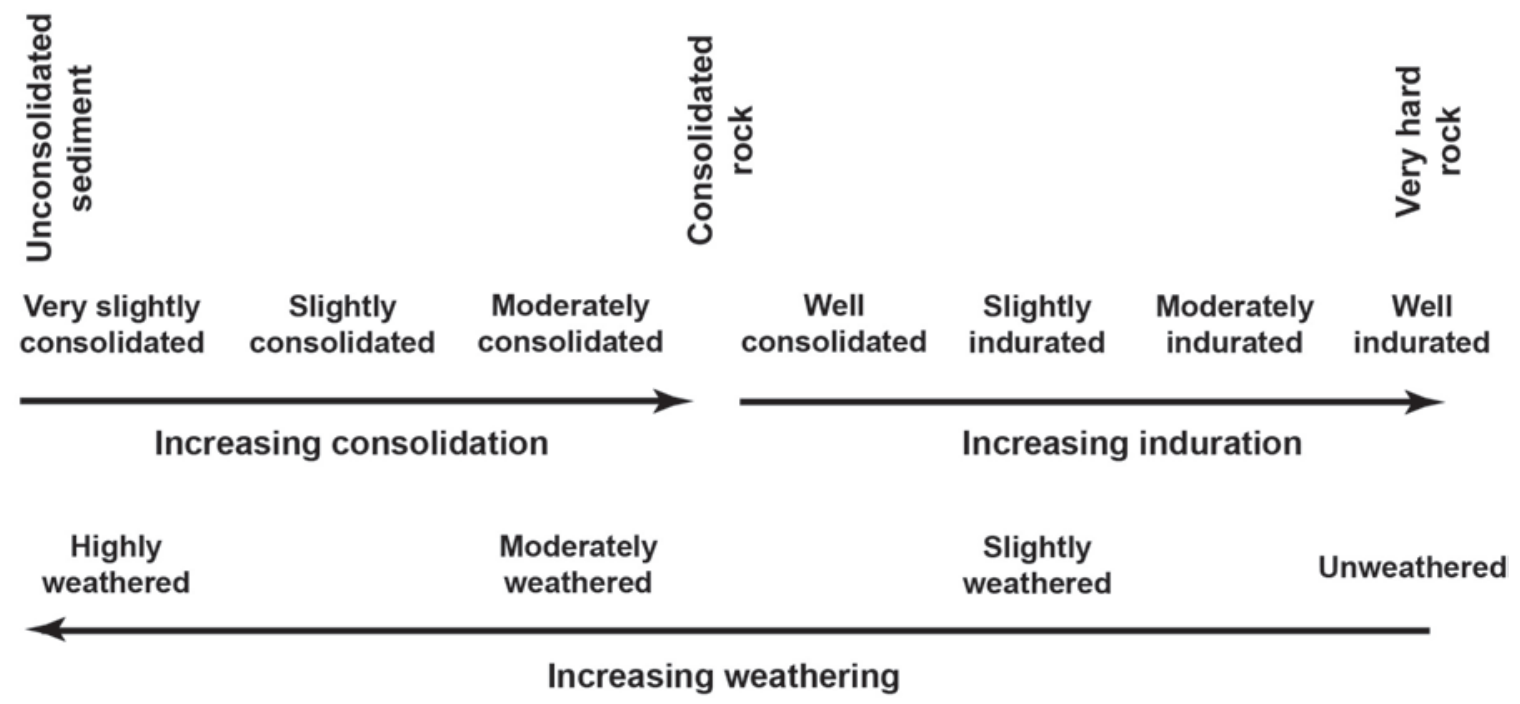

Text-Figure 1.--Pathways of prograde consolidation and retrograde weathering, with attendant science language (adapted from North American Geologic-map Data Model Science Language Technical Team, 2004, p. 28, Text-figure 1)

For discussion purposes, [we view] consolidation as a linear process that leads from loose unconsolidated sediment to hard indurated rock [text-fig. 1]. By contrast, weathering is a process that reverses the consolidation state-whatever consolidation state was achieved originally. A given outcrop or volume of sedimentary material will reflect a sort of equilibrium between prograde lithification (that tends to consolidate a sedimentary material) and retrograde weathering (that tends to disaggregate a sedimentary material). [text-fig. 1] attempts to convey this equilibrium. Two sets of vocabulary must be developed to reflect the two competing processes, and the mapping geologist must diagnose which process is dominant for a particular sedimentary volume and use the appropriate vocabulary to communicate this diagnosis.

This document can explore issues pertaining to consolidation and can suggest guidelines for distinguishing unconsolidated from consolidated materials but, bottom line, it still will be the decision of the data producer as to whether a specific sedimentary material is "lithified" or "unlithified" according to his or her judgment. Such decisions should follow the guidelines in [table 1]." 
Table 1. Terms for degree of consolidation in surficial materials, together with threshold definitions (modified from table 13.2.6.1 in North American Geologic-map Data Model Sedimentary Science Language Technical Team, 2004, p. 87, which cites Bowles, 1984, p. 151-152).

\begin{tabular}{|c|c|c|c|}
\hline & Consolidation state & Field criterion & Relative Density $\left(D_{r}\right)^{1}$ \\
\hline \multirow{3}{*}{ 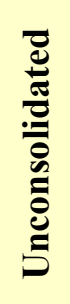 } & $\begin{array}{l}\text { Very slightly } \\
\text { consolidated }\end{array}$ & Easily indented with fingers & $0.00-0.20$ \\
\hline & Slightly consolidated & $\begin{array}{l}\text { Somewhat less easily indented with } \\
\text { fingers. Easily shoveled }\end{array}$ & $0.20-0.40$ \\
\hline & $\begin{array}{l}\text { Moderately } \\
\text { consolidated }\end{array}$ & Shoveled with difficulty & $0.40-0.70$ \\
\hline \multirow{2}{*}{ 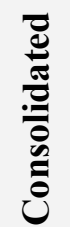 } & Well consolidated & $\begin{array}{l}\text { Requires pick to loosen for } \\
\text { shoveling }\end{array}$ & $0.70-0.90$ \\
\hline & Indurated & $\begin{array}{l}\text { Requires blasting or heavy } \\
\text { equipment to loosen }\end{array}$ & $0.90-1.00$ \\
\hline
\end{tabular}
report.

The terminology and guidelines in table 1 seem as good as any, and they are adopted for this

Note in table 1 that the boundary between "unconsolidated" and "consolidated" ("not-rock" and "rock") falls where sedimentary materials are so coherent that a pick is required to disaggregate the material before its constituents can be shoveled; in other words, the mass of materials resists breaking. The North American Geologic-map Data Model Sedimentary Science Language Technical Team applies the term "well consolidated" to such materials, which by definition are "rock". Map units of surficial materials by and large consist of very slightly to moderately consolidated sediment, although they locally may contain lithified material as defined in table 1.

We use three kinds of information to classify surficial materials in the El Casco quadrangle:

- geomorphic setting (physiographic setting) and mode of origin (alluvial-fan, colluvial, slope movement, and so forth);

- age (as interpreted mainly from pedogenic-soil characteristics, but also by degree of erosional dissection and from sparse radiocarbon-age determinations);

- physical properties and lithologic features (including consolidation, depositional fabric, particle size and particle sorting, particle composition, matrix support versus grain support).

Our inclusion of genesis as a factor in mapping surficial materials runs counter to the way map units of consolidated materials are classified. According to the North American Stratigraphic Code (North American Commission on Stratigraphic Nomenclature, 1983), surficial geologic-map unitssuch as map units of consolidated materials - should be defined on the basis of descriptive lithologic and stratigraphic features (lithostratigraphic units) or bounding unconformities (allostratigraphic units); highly interpretive and derivative criteria such as genesis typically should be avoided. Despite these

\footnotetext{
${ }^{1}$ As translated by Bowles (1984, p. 151-152), relative density is an engineering parameter that relates void space determined in the laboratory to a ratio involving index values of minimum and maximum void space for specified materials under specified sediment. Void space in turn is related to in situ dry unit weight.
} 
guidelines, use of genetic criteria as a basis for classifying and mapping surficial materials seems inescapable: the materials for the most part are so similar lithologically that factors other than physical stratigraphy need to be used if any sort of stratigraphic classification and interpretive framework are to be achieved. Because the surficial materials have formed so recently - and in some cases are actively forming on the modern landscape - their physical properties and overall stratigraphic characteristics can be linked clearly to their genesis and physiographic setting. Thus, it is useful to use genetic factors in the mapping of these materials, and in the El Casco quadrangle surficial materials that have the same genesis are candidates for inclusion within the same geologic-map unit-assuming they are about the same age (discussed below).

Figure 3 illustrates the hierarchical basis for classifying surficial geologic-map units in the El Casco quadrangle, showing how physiographic setting and genesis figure into naming the units. Most surficial units in the quadrangle are classified into two major alluvial categories: (1) axial-valley materials deposited in lowlands by throughgoing rivers and streams that flow longitudinally down valley axes (units of Qvya, Qya, Qoa, and Qvoa) and (2) alluvial-fan materials deposited as cone-shaped aprons that flank the margins of hills and mountains or that build down onto throughgoing axial-valley plains from lateral tributaries (units of Qvyf, Qyf, Qof, and Qvof). Additional categories include lacustrine materials deposited in lakes (units of Qvyl and Qyl) and slope-movement materials formed by landslides and other kinds of slope-movement processes (units of Qvyls, Qyls, and Qols).

Axial-valley and alluvial-fan deposits both are categories of alluvium: that is, sediment deposited mainly by stream flows (although alluvial-fan deposits can include sediment-gravity flow deposits). Because of their similar origin, the two alluvial deposit types have generally similar lithologic characteristics and physical properties (for example, bedding attributes, sedimentary structures). How, then, can alluvial deposit types be distinguished other than by original physiographic setting and genesis, especially considering that physiographic setting can be difficult to reconstruct for older deposits that have undergone information loss due to erosion, deformation, or burial by younger units?

In general, axial-valley and alluvial-fan deposits differ in the following general ways:

- alluvial-fan sequences typically are coarser grained, more poorly sorted, and more crudely stratified than axial-valley sequences, and commonly having more gravel-size sediment;

- axial-valley sequences typically have more layers of clay, silt, and organic-rich material (peat) than do alluvial-fan sequences;

- alluvial-fan sequences tend to have matrix-supported sediment-gravity flow deposits (debris flows, mud flows) that are relatively uncommon in axial-valley sequences;

- where axial-valley and alluvial-fan sequences are traced in a known or inferred upstream direction, alluvial-fan deposits tend to coarsen and lose fine-grained interbeds more rapidly than do their axial-valley counterparts.

Although the general character of each alluvial unit persists throughout the map area, in detail the units vary both laterally and vertically. For example, between localities only a few tens of meters apart, specifics of sediment interlayering, consolidation, and grain-size variation for a given map unit may differ markedly. This results from three factors: (1) local channel networks that yield local sediment bodies have different bedloads, different stream power, and different source characteristics; (2) channel networks migrate from season to season and year to year, leading to unpredictable lateral variations; and (3) the interface between different alluvial environments (for example, axial valley versus alluvial fan) can change location rapidly within short time periods. Similar variations occur vertically: at a given site, physical properties observed in the upper few meters of a unit may not extend very far into the subsurface, and it may be underlain after only a few meters by materials having different properties, or even by an older unit. Such vertical variability results because surficial settings and their resulting 
deposits may not persist at one location long enough to yield a thick accumulation of sediment having consistent physical properties. These factors all contribute to lithologic variability both laterally and vertically within and between map units of alluvial materials.

In addition to genesis and physiographic setting, the recognition and naming of surficial geologic-map units in the El Casco quadrangle incorporates geologic age (fig. 3). This also runs counter to the rules by which map units of consolidated materials are recognized and classified. According to the North American Stratigraphic Code (North American Commission on Stratigraphic Nomenclature, 1983) geologic age should play no role in the definition, characterization, and classification of bodies of earth material. However, because surficial materials form during relatively short time spans that can be measured and grasped comfortably (a few thousand years can be envisioned, a few million years seems unimaginable), the distribution of surficial materials across the landscape takes on geospatial patterns that clearly can be related to time. Throughout the Inland Empire region can be found many examples of time-arrayed surficial units. For example:

- Mountain canyons display flights of alluvial terraces, each formed by different pulses of canyon-filling alluvium or by down-cutting stream events;

- Alluvial fans flanking the mountains form different-aged units nested one into another;

- Nested terraces underlain by deposits of various ages flank the channels of Santa Ana River and Lytle and Cajon Creeks.

These sequences develop because geologic and climatic conditions vary over time, and such variations trigger responses in the geologic, biologic, and geomorphic processes that operate at Earth's surface. Because surficial materials are linked directly to these processes, one deposit of such materials can give way abruptly to another deposit as ambient conditions change. If the deposits have not been stripped away by erosion or concealed by younger materials, a succession of stacked alluvial sequences will be result that can be subdivided into map units on the basis of relative age. As part of the geologicmapping process, the geologist interprets how the unit sequence in one area relates temporally to that in another area. Thus, as a classification factor, geologic age is useful to the recognition and mapping of surficial earth materials, and materials of the same age are candidates for inclusion within the same geologic-map unit - provided genetic and physical stratigraphic criteria are met.

Figure 4 illustrates regional and global chronologies within which surficial materials of the El Casco quadrangle can be compared. Figure 5 and Figure 6 indicate where we think surficial map units in the El Casco quadrangle fit within this chronology, especially in comparison with the succession of alluvial-terrace fills recognized by Bull (1991) in the San Gabriel Mountains and in the desert regions of southern California. Our classification scheme breaks out four major age-based surficial families (table 2):

Table 2. Time-stratigraphic intervals (Qvy, Qy, Qo, Qvo) recognized in Inland Empire region of southern California; also see figure 5.

\begin{tabular}{|c|l|}
\hline Series & \multicolumn{1}{c|}{ Description } \\
\hline $\begin{array}{c}\text { Very young } \\
\text { series } \\
\text { Qvy units) }\end{array}$ & $\begin{array}{l}\text { The geologically most recent suite of deposits; they formed essentially in equilibrium with modern } \\
\text { climatic and landscape conditions. The map units include unconsolidated modern deposits that are } \\
\text { active, as well as those that are intermittently active during major flood events or those that appear to } \\
\text { have been abandoned by all but the most extreme flood events. The deposits generally lack } \\
\text { pedogenic-soil profiles, and they are not dissected. The lower age boundary of Qvy units is not well } \\
\text { constrained, but appears to range from about 250 to as much as 500 yr b.p. }\end{array}$ \\
\hline
\end{tabular}


Table 2. Time-stratigraphic intervals (Qvy, Qy, Qo, Qvo) recognized in Inland Empire region of southern California; also see figure 5.-Continued

\begin{tabular}{|c|c|}
\hline Series & Description \\
\hline $\begin{array}{l}\text { Young series } \\
\text { (Qy units) }\end{array}$ & 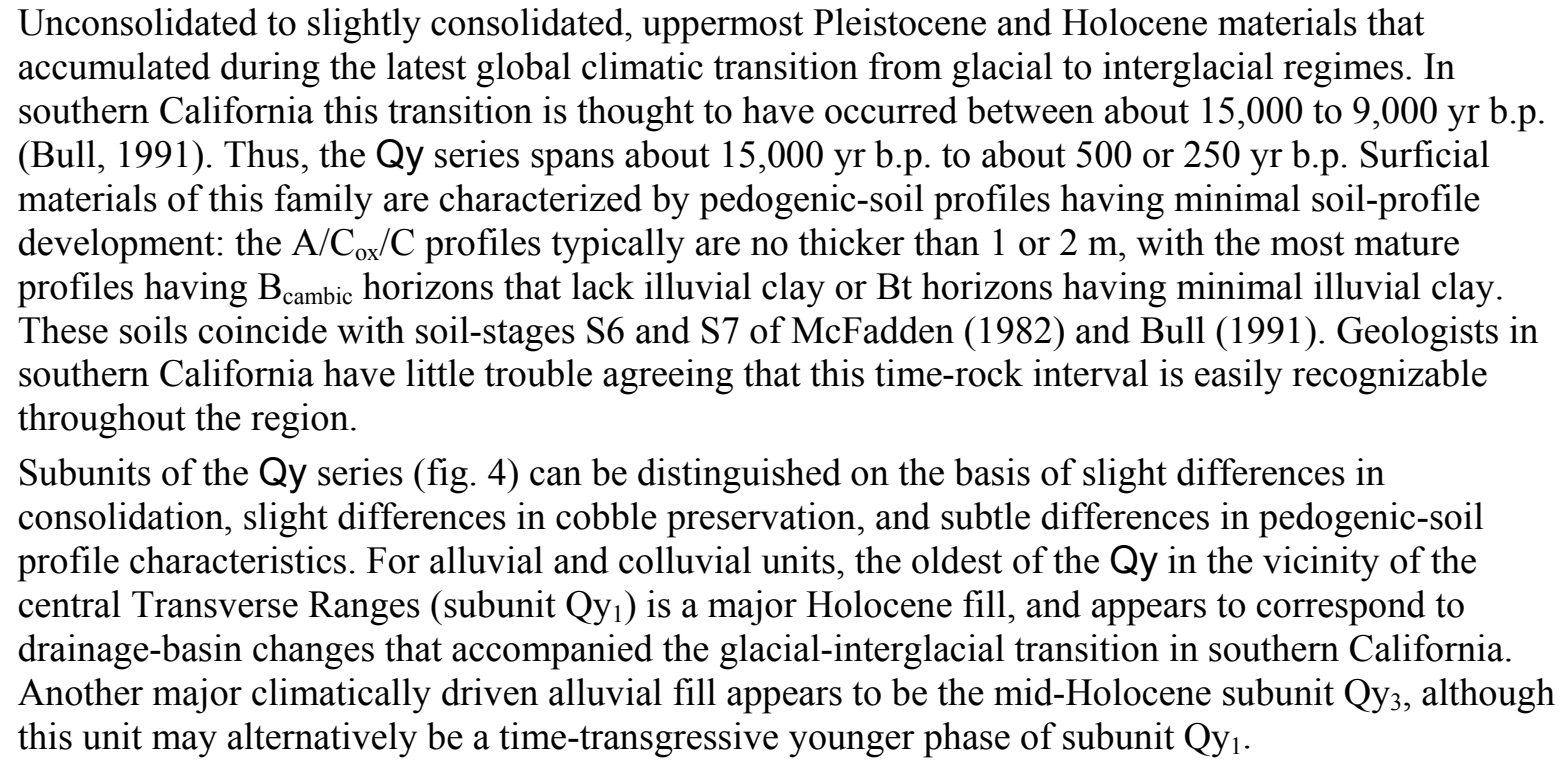 \\
\hline $\begin{array}{l}\text { Old series } \\
\text { (Qo units) }\end{array}$ & $\begin{array}{l}\text { Moderately to well-developed argillic or calcareous soil profiles, are dissected but not too } \\
\text { extensively, and their original landforms and physiographic relations can still be deciphered from } \\
\text { geomorphic and geologic evidence. These are surficial materials that formed during the last few } \\
\text { hundred thousand years, although age control for the map units currently is not good. Surficial } \\
\text { materials of this age are characterized by pedogenic-soil profiles having red B horizons as thick as } 2 \\
\text { m; soils having this degree of rubification are comparable to soil-stages S3, S4, and S5 of McFadden } \\
\text { (1982) and Bull (1991), and probably are between 15,000 and 500,000 years old. }\end{array}$ \\
\hline $\begin{array}{c}\text { Very old } \\
\text { series } \\
\text { (Qvo units) }\end{array}$ & $\begin{array}{l}\text { Moderately to well-consolidated deposits that formed in middle to early Pleistocene time from about } \\
500,000 \text { yr b.p. to about } 750,000 \text { yr b.p.. Undoubtedly, global-climate events during this period } \\
\text { contributed to cycles of nonmarine sediment accumulation or erosional dissection in the Inland } \\
\text { Empire region. However, we have not worked out linkages between such global events and the Qvo } \\
\text { surficial succession. Surficial deposits of this series in the Inland Empire region either have well- } \\
\text { developed argillic or calcareous soil profiles (very red B horizons as thick as } 3 \text { m comparable to soil- } \\
\text { stage S2 and S1 of McFadden, 1982; and Bull, 1991), or their soil profiles have been completely } \\
\text { removed by long-continued erosion. The deposits typically are so dissected by erosion that their } \\
\text { original landforms and physiographic relations cannot be easily deciphered from geomorphic and } \\
\text { geologic evidence. Defined in this fashion, deposits of the Qvo series are distinguished from Qo } \\
\text { units not because they have a unique set of climatic drivers of different duration or intensity, but } \\
\text { because they are not as well preserved in the southern California landscape. There is nothing magical } \\
\text { about the } 500 \text { ka boundary between the Qvo series and the Qo series: this boundary simply separates } \\
\text { generally well dissected surficial materials having very well developed soils (Qvo series) from less } \\
\text { dissected materials having moderately developed soils (Qo series) }\end{array}$ \\
\hline
\end{tabular}

Currently, we cannot confidently correlate surficial geologic-map units in the El Casco quadrangle with a global climatically driven chronology. For one reason, our principal method of estimating geologic age is the textural and compositional character of pedogenic-soil profiles that cap many of the surficial deposits. In general, this allows us to compare the age of the surficial units relative to each other, and to speculate about where each unit falls relative to the provisional chronology developed by Bull (1991). Unfortunately, soil profiles in the El Casco quadrangle have been analyzed 
carefully only in a few areas (Kendrick, 1996, 1999; Kendrick and others, 1994, 2002; also see Knecht, 1971); moreover, during our geologic mapping we examined soil profiles only in a perfunctory way.

Until careful investigations of pedogenic soils are conducted, or until numerical geochronologic data are obtained using radiometric-age determinations, our mapping and correlation of surficial materials in the El Casco quadrangle is provisional and subject to modification and revision.

Surficial map units in the El Casco quadrangle constitute a subset of many such units recognized in the Inland Empire region (see Morton and Miller, 2006). We have tried to correlate the El Casco units with what we believe to be their counterparts within the regionwide surficial classification hierarchy (see Correlation of Map Units; figs. 5 and 6 summarize principal components of the regionwide classification). This correlation process means that some map units identified in the quadrangle appear to be out of sequence: for example, we recognize unit Qvof ${\text { but not older units } Q v f_{2} \text { and } Q v \text { of }}_{1}$, and units Qya 3 , Qya, and Qyas, but not units Qya 1 or Qya.

\section{Use of Quaternary Period}

A beginning age for the Quaternary Period has varied historically as the global scientific community has struggled with how to define the boundary between the Quaternary and the preceding Tertiary Period. Many geologic maps published for southern California over the last 30 years or so use an age of $\sim 1.7 \mathrm{Ma}$ for this boundary (following Berggren and others, 1995). Recently, the global community has adopted an older age for this boundary at about 2.6 Ma (Gradstein and others, 2004; Ogg and others, 2008; see U.S. Geological Survey Geologic Names Committee, 2010). This revised boundary lengthens the Quaternary Period by almost a million years.

This revision has no impact on issues discussed in this report, however: as discussed above, in the Inland Empire region sedimentary materials older than $~ 1$ Ma no longer qualify as "surficial" because they typically have been converted from "not rock" to "rock" (see figs. 4 and 5). Thus, whether the base of the Quaternary is 1.7 Ma or 2.6 Ma does not matter except as this boundary determines the duration and boundaries of such qualifiers as "late", "middle", and "early"-which have different meanings for a lengthened Quaternary Period than they do for a shorter one.

\section{Methods for Mapping Surficial Units}

The mapped distribution of surficial materials is based mainly on interpretation of aerial photographs. The primary photography source is 1953-vintage 1:24,000-scale black-and-white photographs (Agricultural Stabilization and Conservation Service, ASCS symbol AXM and AXL). Interpretations based on this photo series were evaluated, refined, and (or) modified using the following photography resources: (1) 1938-vintage, 1:24,000-scale black-and-white photographs (ASCS symbol AXM and AXL); (2) 1972-vintage, 1:30,000-scale U.S. Geological Survey (USGS) black-and-white photographs (symbol GS-VBNS); and (3) 1975-vintage, 1:24,000-scale true-color photography flown for the USGS in May and June 1975 by Pictorial Crafts, Inc.

Aerial-photographic interpretation was augmented with field observations by the authors, and with a variety of subsurface-borehole investigations conducted by various entities, including:

- California Department of Transportation (Caltrans) in support of highway overpass and underpass installations. NOTE: in Caltrans borings, the terms "poorly graded" and "well graded" equate with well-sorted and poorly sorted, respectively;

- U.S. Geological Survey (Rewis and others, 2006) in support of groundwater investigations in cooperation with the San Gorgonio Pass Water Agency. 
Locations for selected subsurface investigations are depicted on the geologic map. All locations for trenching and borehole investigations used to make the geologic map are contained in the digital coverage elcs_obs_points (see accompanying Database User Guide).

\section{Summary of Surficial Categories}

Quaternary surficial materials occur throughout the El Casco quadrangle, but are common only in two areas: (1) in the north half of the quadrangle in drainages of San Timoteo Creek, and (2) in the southwest corner of the quadrangle in the San Jacinto Valley.

San Timoteo Creek drainage-San Timoteo Creek is a major intermittent stream situated north of the San Timoteo Badlands (fig. 1). The trunk canyon and its tributary canyons have been incised into surficial deposits of various ages, into the sedimentary deposits of Live Oak Canyon (new unit), and into sedimentary rocks of the San Timoteo formation of Frick (1921). San Timoteo tributaries that head northward and northeastward are extensive and form a regionally integrated drainage network, only part of which is represented in the El Casco quadrangle (fig. 1). Tributaries that head southward into the Badlands commonly are short relative to their width, and many are beheaded by aggressive headward erosion from steams that drain southward into the San Jacinto Valley. Morton and others (1990) and Kendrick (1999) describe the history of these drainage systems. San Timoteo Creek heads southeast into the Beaumont quadrangle as a minor watercourse that ends abruptly. At the east margin of the quadrangle, however, San Timoteo Creek is joined by Little San Gorgonio Creek, a major tributary that heads northeast into the San Bernardino Mountains and extends the San Timoteo Creek drainage basin well beyond the bounds of the El Casco quadrangle. This drainage basin has evolved over the last several hundred thousand years in response to tectonism within the San Andreas Fault system and influenced by various glacial and interglacial climatic regimes that affected this part of southern California.

San Jacinto Valley - The San Jacinto Valley is a major sediment sink that occupies the southwest corner of the El Casco quadrangle. Here, the Valley slopes gently to the southeast and, just beyond the quadrangle, forms the flood plain of the San Jacinto River (fig. 1). Sediment of the San Jacinto Valley in the El Casco quadrangle largely is derived from headward erosion into the San Timoteo Badlands. Canyons and arroyos incised into the Badlands cannibalize easily eroded sedimentary materials of the San Timoteo formation of Frick (1921) and feed detritus into the San Jacinto Valley, where it accumulates mainly as alluvial-fan deposits. One well-formed alluvial fan debouches from the unnamed canyon directly west of Jackrabbit Trail (fig. 1); other less-distinct fans debouche from canyons to the northwest, and these largely have coalesced into a fan complex that forms the southeast-sloping floor of San Jacinto Valley. Where this sloping surface meets the relatively flat floodplain of the San Jacinto River, subsidence within the San Jacinto graben (Lofgren and Meyer, 1975; Lofgren, 1976) has produced a closed depression (Morton, 1977) that commonly fills with a standing body of water known locally as "Mystic Lake".

\section{Very Young Deposits (Qvy Series)}

Surficial deposits of this family consist of sandy and gravelly deposits that are no older than a few hundred years, and generally lack pedogenic-soil profiles.

\section{Very Young Alluvial Deposits}

Very young wash deposits - These occupy modern channels of axial-valley streams and alluvial fans. The deposits occur in variety of physiographic settings: (1) sediment in channels and arroyos incised into older map units; (2) sediment in networks of narrow, anastomosing channels distributed around terraces of older units; and (3) sediment forming thin, continuous to discontinuous veneers that 
mantle older units. The deposits are most extensive in the drainage basin of San Timoteo Creek, where they commonly occur in channels and washes incised into slightly older valley alluvium. Very young wash deposits also occur on the San Jacinto Valley floor and in canyons that head northward into the San Timoteo Badlands.

Very young alluvial-fan deposits - These are undissected deposits of sandy and gravelly sediment that form the active parts of alluvial fans. The deposits occur only locally in the quadrangle, mainly along the boundary between the San Timoteo Badlands and the San Jacinto Valley.

\section{Very Young Lacustrine Deposits}

In the southwest corner of the El Casco quadrangle, where the southeast-sloping San Jacinto Valley floor merges with the floodplain of the San Jacinto River, overbank-flood events from the river spill northward into the El Casco quadrangle and form a standing body of lake water known locally as "Mystic Lake". The lake can persist for multiple seasons, and yields fine-grained lacustrine sediment deposited on the alluvial-valley floor. Over geologic time this leads to interstratification of alluvial and lacustrine sediment that comprises the sedimentary fill of the valley floor. To emphasize the recent lacustrine genesis of sediment on this part of the valley, we map uppermost surficial deposits here as lacustrine unit Qvylm.

\section{Very Young Landslide Deposits}

We map very young landslide deposits (unit Qvyls) here and there throughout the El Casco quadrangle; in the vicinity of U.S. Highway 60 many of these along with others not mapped by us are recognized by Manson and others (2002). We assign these deposits to the Qvy series of surficial materials (uppermost Holocene) because they are not dissected and because their landslide geomorphology (scarps, hummocky ground, rumpled toes) is well preserved.

\section{Young Deposits (Qy Series)}

Surficial materials of the Qy series are Holocene to uppermost Pleistocene in age (between $\sim 15,000$ and a few hundred years old). Alluvial sediments of the series are sandy and gravelly deposits characterized by pedogenic-soil profiles having minimal soil-profile development; the deposits are capped by $\mathrm{A} / \mathrm{C}_{\mathrm{ox}} / \mathrm{C}$ pedogenic-soil profiles no thicker than 1 or $2 \mathrm{~m}$, with the most mature profiles having $\mathrm{B}_{\text {cambic }}$ horizons that generally lack illuvial clay. These soil profiles coincide with soil-stages S6 and S7 of McFadden (1982) and Bull (1991) (figs. 5, 6). The sedimentary units are slightly to moderately consolidated and slightly to moderately dissected.

\section{Young Alluvial Deposits}

Young axial-valley deposits - Young axial-valley deposits (unit Qya ${ }_{5}$ ) occur extensively in the San Timoteo Creek drainage basin. There, the deposits commonly form the uppermost capping of valley-floor alluvium, and consist of fine-grained sandy sediment containing variable amounts of gravel particles. Deposits of unit Qya 5 commonly are incised by arroyos and gullies containing active-wash deposits (unit Qvyw), and probably are overtopped only during maximum-flood events. Canyons that head northward into the San Timoteo Badlands from San Jacinto Valley also are floored by deposits we map as unit Qya5, and these, too, commonly are heavily incised by arroyos containing active-wash deposits.

Young alluvial-fan deposits - We map young alluvial-fan deposits (units $\mathrm{Qyf}_{5}, \mathrm{Qyf}_{4}, \mathrm{Qyf}_{3}$ ) extensively in the San Jacinto Valley, where alluvial fans debouche from canyons in the San Timoteo Badlands. There, the deposits consist of sandy and gravelly sediment in various proportions. We have very poor age control on the sequence of units here: soil-profile characteristics (Knecht, 1971) suggest 
that they mainly are middle and late Holocene in age, although they could locally be as old as early Holocene. The units are distinguished mainly on subtle variations and differences in their upper-surface characteristics as determined from aerial-photographic interpretation.

\section{Young Lacustrine Deposits}

Along the south-central margin of the El Casco quadrangle, a subtle geomorphic surface stands slightly above the modern footprint of "Mystic Lake" and downslope from alluvial-fan surfaces that slope gently valleyward from the San Timoteo Badlands. Fine-grained sediment underlying this level surface consists of interlayered fine sandy and muddy sediment that we suspect originated as interlayered lacustrine and fluvial deposits similar to, but older than, those of the modern "Mystic Lake" (unit " $Q v_{\mathrm{sc}}$ " of Morton and Matti, 2001a). We map these deposits as lacustrine unit Qyl 5 to emphasize their lacustrine component.

\section{Young Landslide Deposits}

We map young landslide deposits (unit Qyls) here and there throughout the El Casco quadrangle; in the vicinity of U.S. Highway 60 many of these along with others not mapped by us are recognized by Manson and others (2002). We assign these deposits to the Qy series of surficial materials (Holocene and uppermost Pleistocene) because their landslide geomorphology (scarps, hummocky ground, rumpled toes) is well preserved. Many of the landslide masses are undissected, although older slides in the family are slightly to moderately dissected. Deposits of unit Qyls are inactive under current climatic and tectonic regimes, but could be re-activated under appropriate meteorological and groundshaking conditions.

Young slope-movement deposits are especially well-developed along the southern flanks of San Timoteo Canyon. There, north-dipping strata of the San Timoteo formation of Frick (1921) are especially prone to slope failures, and have shed large displaced bedrock blocks as well as rock slumps and earth slumps (terminology follows Varnes, 1978, fig. 2.1). We suspect that many young landslide deposits in the San Timoteo Badlands are related to base-level changes that lowered canyon bottoms during Holocene time, leading to failure of adjacent hillslopes.

\section{Old Deposits (Qo Series)}

Surficial materials of the Qo series are late to middle Pleistocene in age (probably between 20,000 and 500,000 years old). Alluvial sediments of the series are sandy and gravelly deposits. Where their upper surfaces are well preserved, they are capped by $\mathrm{A} / \mathrm{AB} / \mathrm{B} / \mathrm{C}_{\mathrm{ox}}$ pedogenic-soil profiles having red argillic horizons as thick as $2 \mathrm{~m}$. These soils are comparable to soil-stages S3, S4, and S5 of McFadden (1982) and Bull (1991) (our figs. 5, 6) and to soils capping surfaces Q1 and Q2 of Kendrick (1999; Kendrick and others, 2002). The units are slightly to moderately consolidated and slightly to moderately dissected.

\section{Old Alluvial Deposits}

Old alluvial deposits are most common in the north part of the El Casco Quadrangle, where they form extensive bodies in the drainage basin of San Timoteo Creek. Elsewhere in the quadrangle old alluvial deposits crop out sparsely, although in the San Jacinto Valley they likely constitute much of the subsurface sedimentary fill.

Old alluvial-fan deposits of the Beaumont Plain-San Timoteo Creek and its tributaries have incised into thick bodies of brownish sandy and gravelly sediment (alluvial-fan units Qof 2 and Qof 1 ) that stand well above the valley bottoms. The deposits are capped by a widespread alluvial-terrace surface that forms the Beaumont Plain of Young and others (1941). This surface once extended as a 
continuous feature from the Beaumont area westward through the El Casco quadrangle to Calimesa and Yucaipa (fig. 1), but it has been fragmented by late Pleistocene and Holocene incision of tributaries of San Timoteo Creek. Geologic and geophysical logs from subsurface borings indicate that sediment beneath the Beaumont Plain ranges up to a few hundred feet thick (Rewis and others, 2006). This body of sediment thus is extensive both areally and stratigraphically, and records a depositional history that affected the entire western San Gorgonio Pass region.

The geologic and geomorphic scope of such a regional system is difficult to envision in view of the incised and geomorphically fragmented modern landscape (fig. 1). Today, this landscape is traversed by throughgoing streams that flow south and southwest from long intramontane canyons that dissect the crystalline foothill terrane upstream from the Beaumont Plain (figs. 1, 2; for example, the canyons of Noble Creek and Little San Gorgonio Creek northeast of the El Casco quadrangle, the canyons of Yucaipa Creek and Oak Glen Creek in the Yucaipa quadrangle). Today, sediment in these streams is being transported through and beyond the El Casco and Yucaipa quadrangles. This was not the case

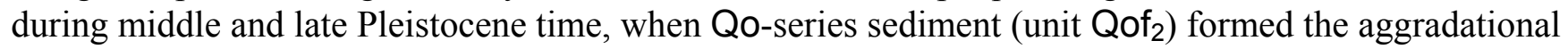
Beaumont Plain north of the San Timoteo Badlands. We interpret this setting as a braidplain formed by coalescing alluvial fans that radiated from the mouths of intramontane canyons like Noble and Little San Gorgonio Creeks and Yucaipa and Oak Glen Creeks.

This paleogeographic model may explain how Qo-series sediment accumulated on the Beaumont Plain, but it raises questions about the regional drainage pattern, hydraulic capacity, and sediment budget of streams that fed the braidplain complex. Such questions arise because the Qo sediment volume beneath the braidplain is so large: ostensibly, its accumulation required an extensive sedimentdelivery system that could spread alluvium across much of the El Casco, Yucaipa, and Beaumont quadrangles. Streams flowing down several intermontane canyons upgradient from the braidplain obviously could funnel sediment through the crystalline foothills, but as conduits for Qo-series sediment these canyons are problematic (see Matti and others, 2003a, p. 15): in the modern landscape they do not appear to have catchment basins large enough to (1) generate streamflows powerful enough to transport sediment down the canyons and distribute it across the braidplain or (2) supply the prodigious volume of sediment represented by Qo-series deposits underlying the braidplain and filling the canyons themselves. Moreover, the intramontane canyons appear beheaded by the San Bernardino strand of the San Andreas Fault (fig. 1). Matti and others (2003a) reasoned that any reconstruction of middle Pleistocene paleogeography in the western San Gorgonio Pass region needs to take into account dextral slip on the San Bernardino strand in late Pleistocene time, reckoned to be about $3 \mathrm{~km}$ in the last $\sim 125 \mathrm{ka}$ years (Matti and others, 1992b; Matti and Morton, 1993, fig. 7K).

Restoration of about $3 \mathrm{~km}$ of dextral slip positions the intramontane canyons near the headwaters of San Gorgonio River, which suggests that this drainage may have been the delivery system for Qoseries sediment beneath the Beaumont Plain. Today, San Gorgonio River flows south through a deeply entrenched canyon and then east through San Gorgonio Pass and into the Salton Trough (figs. 1, 2); the river heads northward into the Yucaipa Ridge block. For it to have once supplied sediment southwest and west into the Beaumont Plain braidplain complex via intramontane canyons like those now occupied by Noble, Little San Gorgonio, and Oak Glen Creeks requires that the landscape during middle Pleistocene time ( $\sim 600 \mathrm{ka}$ to $\sim 150 \mathrm{ka})$ must have looked much different than it does today. We envision the following paleogeographic elements:

1. At one time or another during middle Pleistocene time, streamflows of San Gorgonio River coursed down intramontane canyons in the El Casco and Yucaipa quadrangles (Matti and others, 2003a). Conceivably, more than one of these canyons could have been occupied by coeval tributaries of the River, but this seems improbable. 
2. More likely, the initial fluvial pathway was down the northwesternmost intramontane canyon - the valley of modern Oak Glen Creek; this pathway would have fed Qo-series sediment into the Yucaipa quadrangle, but probably not into the El Casco quadrangle.

3. Ultimately, the Oak Glen Valley pathway was abandoned, and San Gorgonio River probably flowed sequentially down canyons now occupied by Little San Gorgonio and Noble Creeks. This led to the accumulation of Qo-series sediment in the El Casco quadrangle.

4. If valid, this scenario suggests that, during middle Pleistocene time, the path of San Gorgonio River downstream from its head in the Yucaipa Ridge block progressively migrated counterclockwise - that is, from west to southwest to south.

5. If maintained, this counterclockwise trend would culminate in today's landscape, where the San Gorgonio River flows south and southeast through San Gorgonio Pass (fig. 1, fig. 2).

If this paleogeographic scenario is valid, the landscape of western San Gorgonio Pass has been modified considerably from that of middle Pleistocene time. This probably can be attributed to late Quaternary dextral slip on the San Bernardino strand. Any former route of San Gorgonio River southwestward toward the El Casco and Yucaipa quadrangles has been disrupted by late Quaternary fault movements that significantly reorganized landscapes in the western San Gorgonio Pass region.

In the El Casco quadrangle, old alluvial-fan unit Qof $_{2}$ in the San Timoteo Creek drainage is compatible with this paleogeographic model:

- In the east part of the quadrangle, Qof $_{2}$ was deposited from streams that headed into foothills north of Cherry Valley in the adjacent Beaumont quadrangle, and almost certainly flowed down canyons of ancestral Little San Gorgonio River and Noble Creek (fig. 1).

- In the Calimesa area, unit Qof 2 was deposited from streams that headed northeast into Wildwood Canyon in the Yucaipa quadrangle (fig. 1; Matti and others, 2003a), which in turn connects to the canyon of Little San Gorgonio Creek.

- Pleistocene sediments in all of these canyons are interconnected, and contain pebbles, cobbles, and boulders derived from crystalline rocks of both San Gabriel Mountains-type and San Bernardino Mountains-type (fig. 2).

- In the El Casco quadrangle these sediments fanned out downstream from the intramontane canyons and spread out south and southwest onto older units. In some instances the latter consist of the San Timoteo formation of Frick (1921) that are capped by a residual soil (unit Qvors); unit Qof 2 clearly occupies paleovalleys incised into these older units, and buttresses unconformably against highground underlain by them. In other instances the older units consist of very old alluvial-fan deposits of unit Qvof 3 that represent an earlier alluvial cycle similar to that of the Qo series. Clearly, unit Qof $_{2}$ in the north part of the El Casco quadrangle represents alluvial sediment that backfilled an erosional landscape carved by ancestral streamflows of San Timoteo Creek and its tributaries. To the north and northeast, this drainage basin probably was integrated with that of San Gorgonio River.

Therefore, although we map Qo units in the San Timoteo Creek drainage as alluvial-fan deposits, these should not be viewed as isolated paleogeographic features unique to the El Casco quadrangle but rather as elements of a widespread depositional regime that appears to have developed in the western San Gorgonio Pass region during middle Pleistocene time.

Other old alluvial-fan deposits - In the Mt. Eden area, we map small bodies of Qof that rest on geomorphic surfaces beveled onto sedimentary rock of the Mt. Eden formation of Frick (1921). The deposits consist mainly of angular gravelly and sandy material derived from crystalline rock of the Mt. 
Eden inselberg as well as material derived from the underlying Mt. Eden formation. We have no age control on these deposits, although locally they have reddened argillic horizons that suggest they should be grouped within the Qo series. Clearly, they are part of the complex landscape that has evolved in the Mt. Eden area associated with faulting and uplift of the Mt. Eden inselberg.

In the San Jacinto Valley, alluvial bodies of the Qo series occur only locally, along the margin of the San Timoteo Badlands and around the margins of Peninsular Ranges inselbergs. The San Jacinto graben has been subsiding so rapidly throughout Pleistocene and Holocene time (Lofgren and Meyer, 1975; Morton, 1977) that deposits of the Qo series largely have been concealed by overlying deposits of the Qy series. The older deposits are exposed only along the margins of the Valley, where they are preserved in isolated uplifts.

\section{Old Landslide Deposits}

Old landslide deposits (unit Qols) occur locally in the El Casco quadrangle. We assign these deposits to the Qo series of surficial materials (middle to upper Pleistocene) because their original landslide geomorphology has been heavily modified by weathering and erosion. The deposits are moderately dissected to well dissected; in some instances, landslide bodies have developed residual pedogenic-soil profiles having reddened argillic horizons. Deposits of unit Qols are inactive under current climatic and tectonic regimes, but could be reactivated under appropriate meteorological and ground-shaking conditions.

One old landslide complex directly west of the unnamed canyon west of Jackrabbit Trail (center of Section 22, T $3 \mathrm{~S}, \mathrm{R} 2 \mathrm{~W}$ ) merits comment. The complex consists of multiple slide masses containing both intact blocks and disorganized rubble derived from the San Timoteo formation of Frick (1921) directly to the north; individual landslide masses are separated by distinct crown scarps. The complex is dissected extensively by arroyos and gullies heading northward from San Jacinto Valley, and some of these contain young alluvial deposits of probable Holocene age. These geomorphic and geologic relations testify to the overall age and relative stability of most of the old landslide complex. That said, young topographic scarps along Gilman Hot Springs Road west of the slide complex (see discussion of geomorphic features, below) not only break Holocene alluvial deposits but also the leading edge of the older slide complex. We do not know whether these young scarps resulted from reactivation of the older complex, or whether they are unrelated to it. We suspect that the old landslide mass in Section 22 was generated in an area of tectonic and landscape instability where a left step evolved in the San Jacinto Fault zone (discussed below): the landslide occurs on the moderately to steeply dipping south limb of the San Timoteo Anticline, and may have evolved where that structure encountered contractional strain associated with the left-stepping fault zone.

\section{Very Old Deposits (Qvo Series)}

Surficial materials of the Qvo series are middle to early Pleistocene in age (probably between 500,000 and 700,000 years old). In the El Casco quadrangle, alluvial sediments of the series are sandy and gravelly deposits. Where their upper surfaces are well preserved, they are capped by $A / A B / B / C_{o x}$ soil profiles having red argillic horizons as thick as $3 \mathrm{~m}$. These soil profiles are comparable to soil-stage S2 of McFadden (1982) and Bull (1991) (figs. 5, 6) and soils capping surface Q3 of Kendrick (1999; Kendrick and others, 2002). The sedimentary units are slightly to moderately consolidated and moderately to well dissected.

\section{Very Old Alluvial Deposits}

The only very old alluvial deposits we map in the El Casco quadrangle are alluvial-fan deposits (unit Qvof 3 ). These occur in the drainage basin of San Timoteo Creek where Qvof 3 is buttressed 
unconformably against highground underlain by the sedimentary deposits of Live Oak Canyon. In outcrops, the very old deposits are not easy to distinguish from alluvium of the younger Qo series (unit Qof $_{2}$ ), but the latter generally is somewhat less consolidated, and underlie widespread terrace surfaces

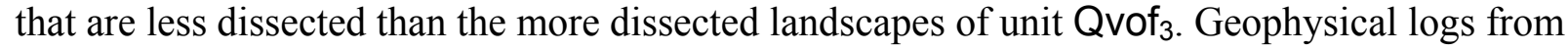
subsurface borings (Rewis and others, 2006) indicate that unit $\mathrm{Qvof}_{3}$ is on the order of several hundred feet thick beneath the alluvial-terrace surface of the Beaumont Plain. Buttressing relations with underlying units indicate that deposits of unit Qvof ${ }_{3}$ accumulated on and backfilled an erosional landscape carved by ancestral streamflows of San Timoteo Creek and its tributaries. To the north and northeast, this drainage system probably was integrated with that of San Gorgonio River (see preceding discussion of Qof series).

\section{Very Old Residual Deposits}

North of San Timoteo Creek, highground underlain by the sedimentary deposits of Live Oak Canyon (unit Qlo) locally is capped by reddish argillic material and associated nodules, stringers, and irregular layers of white calcium carbonate (caliche and calcrete). From a distance, occurrences of this reddish zone appear to be a younger alluvial deposit overlying unit Qlo. However, we are not able to document two separate alluvial units: instead, we interpret the reddish clay-rich material and carbonate as a zone of deep weathering and pedogenesis that has affected the upper surface of unit Qlo. The zone is residuum and pedogenic soil (unit Qvors) developed on a landscape surface that formed on top of unit Qlo after its deposition and before and during deposition of alluvial deposits of unit Qvof 3 . This weathering zone has been dropped into the subsurface northeast of the inferred position of the San Timoteo Fault (discussed below).

\section{Cenozoic Sedimentary Materials}

Cenozoic sedimentary units in the El Casco quadrangle consist of consolidated rock and unconsolidated sediment that crop out mainly in two areas: within the San Timoteo Badlands, and in low hills and mesas north of San Timoteo Canyon (fig. 1). These materials are important for several reasons: (1) the stratigraphic succession is nearly continuous between the late Miocene and middle Pleistocene, and thus provides a remarkable depositional record of sedimentation and tectonics within the San Andreas Fault system for the last 6 or 7 Ma (Matti and Morton, 1993; Morton and Matti, 1993; Albright, 1999; Kendrick and others, 2002); (2) vertebrate fossils collected from various parts of the stratigraphic succession (Frick, 1921; May and Repenning, 1982; Repenning, 1987; Reynolds and Reeder, 1986, 1991; Albright, 1997, 1999) are important elements of the late Neogene North American land-mammal chronology; and (3) the sedimentary materials are the host for groundwater storage units beneath growing population centers in the Yucaipa-Calimesa-Beaumont-Banning region (Rewis and others, 2006). For these reasons, we describe in detail the stratigraphic nomenclature (fig. 7), stratigraphic relations (fig. 8), lithology, and depositional history of Cenozoic map units within the El Casco quadrangle.

\section{Sedimentary Deposits of Live Oak Canyon (New Unit)}

We informally apply the new name "sedimentary deposits of Live Oak Canyon" to the sequence of sandy and conglomeratic rock that crops out in low hills and mesas north of San Timoteo Canyon. These materials previously have been mapped as "older alluvium" (Burnham and Dutcher, 1960, p. 64-66) or as the upper member of the San Timoteo formation (Morton, 1978b, 1999; Matti and others, 1992a,b, 2003a,b; Albright, 1997, 1999; Morton and Miller, 2006; many unpublished consulting reports). The unit is named for Live Oak Canyon in the Yucaipa 7.5' quadrangle, where the formation is exposed in roadcuts and in low hills flanking the canyon. 
Lithology — The sedimentary deposits of Live Oak Canyon consist of both unconsolidated and consolidated sedimentary materials (see table 1 for distinctions between these two consolidation states). As discussed by Burnham and Dutcher (1960, p. 57-63, their older alluvium), lithologic details in the sedimentary deposits of Live Oak Canyon vary from place to place, although viewed from a distance the unit overall has a fairly uniform appearance. It generally crops out poorly and forms smooth brushy and grassy slopes punctuated intermittently by well-cemented beds that form prominent ledges (fig. 9). In general, coarser grained materials (gravel- and sand-bearing) are more abundant than finer grained materials (mud-bearing). Finer grained materials are yellowish to brownish to light-gray, whereas gravelly and conglomeratic strata are light-gray to very pale-brown; the upper part of the sequence tends to be more yellowish and brownish, thus complicating distinction between unit Qlo and overlying alluvial map units. Sandier sedimentary materials range from thin to very thick bedded and are texturally massive to flat laminated to cross laminated. Gravelly and conglomeratic intervals are thin to thick bedded (figs. 10A, 10B) and mainly have imbricated clasts, although matrix-supported fabrics occur locally; many beds have channelate bases. Clasts in conglomerate and gravel layers include pegmatitic rock and foliated and mylonitic granitoids derived from the upper plate of the Vincent Thrust, Pelona Schist from the lower plate of the Vincent Thrust (mainly greenstone but also minor muscovite schist), and granitoid and gneissic rocks of San Bernardino Mountains-type. Locally, erosion slopes of unit Qlo are littered with resistant cobbles and small boulders of white pegmatite and aplite. The top of the Live Oak Canyon interval is marked by two features: reddish beds that represent buried paleosols (fig. 11), and local unconformities and packets of sedimentary deposits that represent short-lived depositional sequences; these unconformity-bounded intervals are transitional into overlying alluvial units of the Qvo and Qo series.

Stratigraphic boundaries - The upper contact of unit Qlo varies from place to place within the El Casco quadrangle. Along northern tributaries of San Timoteo Canyon, this boundary is an erosion surface that forms the modern landscape. Locally this surface is capped by reddish, clay-rich material that we interpret as a residual soil (unit Qvors). Beds of unit Qlo directly beneath the erosion surface commonly contain ribbons, nodules, and irregular layers of $\mathrm{CaCO}_{3}$ (calcrete); fractures are coated with or filled by caliche. Locally, the erosion surface is overlain with slight angular unconformity by various alluvial deposits: (1) in the vicinity of Calimesa, these consist of unit Qof $_{2}$; (2) in the east-central part of the quadrangle, they consist of unit $\mathrm{Qvof}_{3}$. The unconsolidated units not only were deposited on top of the erosional surface (as with unit Qof ${ }_{2}$ ) but also in paleovalleys eroded into it (unit Qvof $_{3}$ ). The latter relation can be observed best in the east-central part of the quadrangle, where deposits of unit Qvof 3 not only buttress against high-standing hills underlain by unit Qlo but also occupy low areas in between.

The contact between the sedimentary deposits of Live Oak Canyon and the underlying San Timoteo formation probably everywhere is unconformable, although this relation can be observed only in the northeast corner of the El Casco quadrangle. There, in the hills between the Banning and Cherry Valley Faults, folded strata of the San Timoteo formation (middle member, unit QTstm) are overlain with angular unconformity by strata we assign to the sedimentary deposits of Live Oak Canyon. This contact mostly is not well exposed. However, it once was displayed spectacularly in the east-facing wall of an excavation a hundred meters or so west of the right-angle bend in Singleton Canyon Road, north of Interstate Highway 10 (figs. 12A, 12B; courtesy of Jay Martin, CHJ, Inc.). Unfortunately, this outcrop has been destroyed by grading activities related to road construction, and the photographs in figure 12 are the sole record of this critical outcrop. Stratigraphic relations here are consistent with (a) those between the Cherry Valley and Banning faults and (b) those we have observed at the boundary between the El Casco and Yucaipa quadrangles. There (fig. 11), a buttressed unconformity separates the sedimentary deposits of Live Oak Canyon from white to light-gray sedimentary rock that we assign to the upper member of the San Timoteo formation; the latter appears to have formed a low inselberg against which the sedimentary deposits of Live Oak Canyon buttressed unconformably. 
South of outcrops illustrated in figure 11, stratigraphic relations between the sedimentary deposits of Live Oak Canyon and older units have been interpreted differently by previous investigators. In this vicinity, San Timoteo Canyon and its young valley-bottom deposits intervenes between gently dipping sedimentary rocks to the north and strata to the south that unquestionably are part of the San Timoteo formation of Frick (1921). Previously, strata north of the Canyon were thought to be part of the San Timoteo formation, with sequences south and north of the Canyon occupying the upper part of the formation (its upper member as used by recent workers; see Morton and Miller, 2006). To the south in the Badlands, the upper member is known to conformably overlie the middle member of the San Timoteo formation (Morton, 1978, although he did not map individual members of the formation; Morton and Matti, 2001b); here, the boundary interval wraps around the nose of the gently northwestplunging San Timoteo Anticline (Morton and Miller, 2006). As interpreted by earlier workers (English, 1953; Shuler, 1953; Matti and Morton, 1975; Morton, 1978b,c; Matti and others, 1992, 2003a,b; Albright, 1997, 1999; Morton, 1999; Matti and others, 2003a,b; Morton and Miller, 2006), strata north of San Timoteo Canyon are structurally and stratigraphically continuous with the San Timoteo succession where it wraps around the anticline nose in the Sunnymead quadrangle - even though San Timoteo Canyon intervenes between the two successions and its incision has obliterated evidence for a direct stratigraphic connection between them.

We interpret these relations differently. Evidence available to us in the El Casco quadrangle and in adjacent quadrangles suggests that the sedimentary sequence on the north side of San Timoteo Canyon is not part of the San Timoteo formation, but rather is a distinct and separate sedimentary unitour sedimentary deposits of Live Oak Canyon. We conclude that strata of this unit do not occur south of San Timoteo Canyon, but are confined to the low hills to the north. We also conclude that an unconformity separates the two sedimentary formations, and that initial deposits of the Live Oak Canyon sequence buttressed against a landscape surface that developed on the San Timoteo formation as the latter was warped by the San Timoteo Anticline — an event that occurred sometime after about 1.4 $\mathrm{Ma}$, the age of the youngest known fossils obtained from the San Timoteo formation (see summaries in Morton and Matti, 1993, Matti and Morton, 1993, and Albright, 1999). Although the unconformable contact is concealed beneath alluvium of San Timoteo Canyon, caliche-rich and reddened zones locally developed on upper surfaces of the San Timoteo formation south of the Canyon probably represent the exhumed landscape surface against and on which the Live Oak Canyon sequence was deposited.

The sedimentary deposits of Live Oak Canyon appear to be extensive in the subsurface from Calimesa east to Beaumont, and coincide with sedimentary materials that are more permeable and hydrologically more transmissive than tighter rocks of the underlying San Timoteo formation (Rewis and others, 2006). The subsurface distribution of the Live Oak Canyon sequence, together with its gentle structural dips and confinement to outcrops north of San Timoteo Canyon, suggest that the formation is not involved in the plunging San Timoteo Anticline, but rather accumulated in a depression north of the fold as it was growing and developing a landscape uplift.

Depositional origin - Depositional structures, sand:gravel ratios, and lithologic associations indicate that the sedimentary deposits of Live Oak Canyon represent fluvial braidplain deposits. Paleocurrent indicators generally point to the south and southwest, and are consistent with streamflows sourced from north of the El Casco quadrangle. Pebbles and cobbles in the sedimentary layers are similar to basement rocks of San Gabriel Mountains-type in local hills of the El Casco and Yucaipa quadrangles (Matti and others, 2003a), especially large white clasts of aplite and pegmatite (fig. 11). Equally abundant are clasts of San Bernardino Mountains-type similar to bedrock on Yucaipa Ridge in the Yucaipa and Forest Falls quadrangles (quartz-biotite gneiss and foliated granitoids). Streams depositing these sediments probably flowed south through ancestral Yucaipa Valley and southsouthwest through ancestral canyons of Little San Gorgonio River and Noble Creek in the Beaumont and Forest Falls quadrangles (Matti and Morton, 1993, fig. 7I). This depositional regime appears to have 
developed north of the San Timoteo Badlands within a synformal basin that subsided north of highground formed by the evolving San Timoteo Anticline. Older beds of the sedimentary deposits of Live Oak Canyon dip more steeply than younger beds (fanning dips), suggesting that older Live Oak beds have been more affected by tilting associated with the San Timoteo Anticline than have younger beds.

Age and correlation - In the El Casco quadrangle, no fossils have been reported from the sedimentary deposits of Live Oak Canyon, but the unit probably ranges from about 1.2 Ma to younger than $780 \mathrm{ka}$. This interpretation follows from the stratigraphic and structural position of outcrops in the El Casco quadrangle relative to those to the west and northwest, where the unit's age can be constrained.

1. In the Redlands quadrangle directly northwest of the El Casco quadrangle, magnetostratigraphic data (Albright, 1997, 1999) indicate that uppermost beds of the Live Oak Canyon unit postdate the Brunhes-Matuyama magnetic reversal, and thus are younger than about $780 \mathrm{ka}$ (see Matti and others, 2003a, for location of the magnetostratigraphic profile. Note: these workers included the sedimentary sequence within their upper member of the San Timoteo formation of Frick, 1921).

2. Also in the Redlands quadrangle, the lower Live Oak Canyon unit stratigraphically overlies beds of the San Timoteo Formation that contain the middle Pleistocene (Irvingtonian-I) Olive Dell local fauna dated at about 1.3-1.5 Ma (Morton and others, 1986; Repenning, 1987; Morton and Matti, 1993, p. 221). Although San Timoteo Canyon intervenes between the two sequences, the basal Live Oak Canyon beds must be younger than 1.3-1.5 Ma.

3. In the Yucaipa quadrangle, the upper part of the Live Oak Canyon unit contains the middle Pleistocene (Irvingtonian-II) Shutt Ranch vertebrate local fauna dated as about 780 to $990 \mathrm{ka}$ (Reynolds and Reeder, 1986; Albright, 1999; see our fig. 11 for the approximate location of the fossil-collection site).

The sedimentary deposits of Live Oak Canyon in the El Casco quadrangle are along strike with those to the west and northwest, and thus are comparable in age. The unit is lower to middle Pleistocene in age $(<1.3 \mathrm{Ma}$ to $<780 \mathrm{ka})$.

\section{San Timoteo Badlands Succession}

The San Timoteo Badlands parallel the San Jacinto Fault, and extend more than $40 \mathrm{~km}$ from the San Jacinto Mountains northwest to Loma Linda (figs. 1, 13). Canyons and arroyos eroded into the Badlands during the last million years or so (Morton and others, 1990; Kendrick, 1999; Kendrick and others, 2002) reveal a gently dipping to moderately dipping sequence of nonmarine sedimentary materials. The deposits accumulated during a period of sedimentation that began in late Miocene time (probably about 7 or 8 million years ago) and continued into the early Pleistocene (about 1.3 million years ago). In the Badlands, these deposits are warped into a major anticlinal fold that for much of its length plunges gently to the northwest (Morton and Miller, 2006). Due to this gentle tilting, older strata in the sequence crop out in the southeastern San Timoteo Badlands and progressively younger strata crop out to the northwest.

The San Timoteo Badlands sequence first was examined by Frick (1921), who separated it into his "upper San Timoteo deposition" and "lower San Timoteo deposition" (Frick, 1921, p. 317, 335). To the upper part of the sequence Frick (1921, p. 283) applied the name San Timoteo formation; to the lower part of the sequence Frick (1921, p. 283) applied the name "Eden Formation", although elsewhere in his report he referred to these as the "Eden beds" (Frick, 1921, p. 335). Frick's main focus was the classification of fossil vertebrates from the San Timoteo Badlands sequence; accordingly, he did not make a detailed geologic map, nor did he designate type sections for his formational units or document 
their internal and lateral stratigraphic relations. From the outset, then, no solid foundation was established for lithostratigraphic classification of sedimentary materials in the San Timoteo Badlands.

Subsequent to Frick's work, stratigraphic interpretations in the San Timoteo Badlands have varied from worker to worker (see appendix 1). Despite these many investigations, a type section and formal stratigraphic names have not been documented for sedimentary units in the Badlands sequence. Moreover, previous workers have not agreed about stratigraphic relations among these units or internally within them. For this reason, in the El Casco quadrangle we use all stratigraphic nomenclature informally.

Our mapping in the quadrangle and in the adjacent Beaumont, San Jacinto, and Lakeview quadrangles leads to the nomenclature and stratigraphic relations indicated in figures 7 and 8 . This scheme recognizes two major stratigraphic packages - the San Timoteo formation [revised] and the Mt. Eden formation [revised], each having unique lithologic features, depositional histories, and sediment provenances. Our usage conforms to that of some previous workers but departs from that of others, especially with regard to the boundary between the Mt. Eden formation and the overlying San Timoteo formation. Appendix 1 describes the history of stratigraphic interpretation across this important interval.

\section{San Timoteo Formation of Frick (1921), Revised}

\section{Original Definition}

Frick (1921, p. 283) applied the name "San Timoteo beds" to sedimentary rocks in his "upper San Timoteo deposition" (Frick, 1921, p. 335). He (1921, p. 318) provides the following description of the formation [text in square brackets indicate comments by us]:

[The description in the following paragraph applies to the "San Timoteo beds" along a N-S transect that lies in the west part of the El Casco quadrangle].

"The lower hills on the San Jacinto-Moreno Valley side [of the axis of the San Timoteo Anticline] are formed of a series of fine and coarser sandstone interstratified with layers of clay. North across the strike [but south of the San Timoteo Anticline] the latter are followed by the sharp south-dipping beds of the central area, remarkable for their broad layers of heavily cemented fanglomerate, which, more resistant to erosion than the interbedded graybrown and yellow clay sands and sandstones, project in bold weathered bands [thick sheetlike conglomerate layers of our middle member, San Timoteo formation]. Still more to the north the sharply dipping beds of the midelevation [of the Badlands landscape] are followed first by a more gently dipping series and then by a broken indeterminate area that apparently represents the axis of the anticline [San Timoteo Anticline of our usage]. The present crest of the ridge [the Badlands skyline] lies 500 feet higher, and in the midextent of the Badlands a quarter of a mile to the northwest of the axial line. The upper and more recent beds of the north-dipping layers of the crest are more brightly colored and sandy than the older beds lying immediately below both to the north and the south, tending to pink-reddish instead of yellowish tones. They lack, too, the great gray interstratified bands of cemented angular rock fragments so prominent in the lower southern area. [Note: Our observations do not match with Frick's final sentence: in the area north of Interstate Highway 10 to which Frick refers ("north-dipping layers of the crest"), we have observed many thick-bedded conglomerate beds within the stratal succession containing his "pink-reddish" intervals].

The San Timoteo deposit as a whole is strongly characterized by the coarse sand and cobble beds which appear running through the yellowish and pinkish bands of the bluffs, as well as by fragments of the same which form a characteristic litter throughout much of the top soil. The constituent cobbles of the coarser layers while considerably worn on the edges are 
hardly as uniformly rounded as the average resultant of stream deposition. Their angularity as well as the prevalence of mica and occasional considerable amounts of gypsum

[presumably in the mudrock intervals], forbid the consideration of the deposit as of purely alluvial formation. The evidence points rather to its origin as the great slopewash of a semiarid region, the formation for which Professor Lawson has proposed the term 'fanglomerate'."

This description is somewhat generic, but does emphasize the "broad layers of heavily cemented fanglomerate" that characterize the middle part of the San Timoteo interval (our middle member of the formation, unit QTstm). Frick (1921) did not identify a boundary between his "San Timoteo beds" and the underlying "Eden beds", although it is clear from his text and from his plate 44, figure 3, that Frick included within his "Eden beds" a ripple-laminated sandstone sequence. By contrast, we include this sequence in the lower part of our San Timoteo formation, and discuss this revision and its implications in appendix 1.

\section{Usage of This Report}

We apply the name "San Timoteo formation of Frick (1921)" to generally the same sequence of sedimentary materials that Frick (1921, p. 283) grouped within his San Timoteo beds, but with some differences at the base of the formation. The unit is widespread throughout the San Timoteo Badlands region. We separate it regionally into six informal map units (figs. 7, 8), five of which occur in the El Casco quadrangle (an upper member occurs northwest of the El Casco quadrangle in the Sunnymead and Redlands 7.5' quadrangles; Morton and Matti, 2001b; Matti and others, 2003b).

\section{Middle Member (Unit QTstm)}

The middle member forms the middle part of the San Timoteo formation of Frick (1921). In the El Casco quadrangle the unit crops out mainly in the San Timoteo Badlands, where it is traversed by U.S. Highway 60. An isolated outlier of the member occurs in the northeast corner of the quadrangle, between the Banning and Cherry Valley Faults. Here, the conglomerate-rich sequence is isolated from the main San Timoteo sequence but lithologically seems most like the middle member as developed in the Badlands.

Lithology - The middle member consists of four lithologies that distinguish the unit from other members of the formation:

1. sheetlike intervals as much as $10 \mathrm{~m}$ thick of light-gray pebble-cobble conglomerate containing rounded to subrounded clasts of granitic, gneissic, mylonitic, and hypabyssal rock of San Gabriel Mountains-type (figs. 14, 15). Pelona Schist (greenstone variety) occurs in stratigraphically higher parts of the middle member. The sheetlike conglomerate beds are the most characteristic lithology in the middle member;

2. medium- to thick-bedded, light-gray to very pale-brown intervals of well sorted, fine- to coarse-grained sandstone. These are texturally massive to flat-laminated to trough crosslaminated (figs. 14, 15);

3. reddish-colored intervals of siltstone and fine sandstone that locally are clay rich. Some of these intervals may be paleosols, but most appear to be eolian in origin.

4. Greenish-gray siltstone, very fine sandstone, and mudstone are not common, although they occur locally in the middle member sequence.

Stratigraphic boundaries - Depending on location within the El Casco quadrangle, the middle member of the San Timoteo formation is overlain by different units. In the northeast part of the quadrangle, between the Banning and Cherry Valley Faults, an angular unconformity separates the 
member from the overlying sedimentary deposits of Live Oak Canyon (unit Qlo; see fig. 12). In the San Timoteo Badlands the middle member is overlain transitionally by the upper member (Matti and Morton, 1975), but this boundary occurs northwest of the El Casco quadrangle in the Sunnymead Quadrangle (Morton and Matti, 2001b; Morton and Miller, 2006). There, sheetlike conglomeratic beds that typify the middle member give way gradually to a sandier sedimentary sequence where conglomeratic rocks occur mainly as singular beds or sets of beds rather than as thick sheets. In the central part of the El Casco quadrangle the middle member transitionally overlies the lower member (discussed below): the contact is difficult to map, and is marked by gradually increasing conglomeratic beds that characterize the middle member.

Depositional origin - Sheetlike conglomeratic rock containing imbricated clasts interlayered with texturally massive to flat-laminated and trough-laminated sandy rock indicates fluvial sedimentation, with gravel-bed deposition alternating with sand-bed deposition. To us, this suggests a high-energy braidplain setting. Finer grained sandstone and mudstone intervals represent slack water deposits and (or) overbank deposits. Reddish eolian sediment accumulated on subaerial surfaces between channels, and these surfaces locally may have developed paleosols. Paleocurrent indicators (clast imbrications, cross laminations) indicate the braidplain paleoslope was inclined to the southeast, with sediment sourced from crystalline rocks of San Gabriel Mountains-type (Matti and Morton, 1993, fig. $7 \mathrm{H}$ ). It is unlikely that the San Gabriel Mountains themselves were this sediment source, because distinctive mylonitic and granulitic rock types that occur along the south margin of the range (Morton and Matti, 1987) do not occur in middle-member conglomerates. The most likely source for middlemember clast types is crystalline rocks of San Gabriel Mountains-type now concealed beneath Quaternary sediment of San Bernardino Valley.

Age and correlation-Paleontologic and magnetostratigraphic investigations by Albright (1997, 1999; also see Hehn and others, 1996) indicate that the middle member of the San Timoteo formation ranges from a maximum of $\sim 4.0 \mathrm{Ma}$ (early Pliocene) to at least $1.4 \mathrm{Ma}$ (early Pleistocene; fig. 8; Albright, 1999, fig. 12). The basal contact appears to be time-transgressive: from a maximum age of at least 4.0 Ma in the northwest part of the El Casco quadrangle, the contact youngs southeastward to about 3.1 Ma in the vicinity of Jackrabbit Trail (Albright, 1999, p. 1290, fig. 13). Decreasing age to the southeast is compatible with progradation of middle-member deposits down a southeast-dipping paleoslope. Recent paleontologic investigations by Reynolds and others (2013) indicate that middle member strata east of Albright's 1.4 Ma El Casco fauna are somewhat older (1.7 Ma), which is consistent with their lower stratigraphic position.

An upper age for the middle member is not known with certainty. Paleontologic and paleomagnetic data (Albright, 1999, fig. 13 and 17, p. 1285) suggest that it is younger than about 1.2-1.4 Ma. Paleontologic constraints derive from the northwest part of the El Casco quadrangle where Albright (1997; 1999, fig. 4) documented the El Casco local fauna. This important microvertebrate fossil assemblage occurs near the top of the middle member, no more than a hundred meters or so below its boundary with the upper member as mapped in the adjacent Sunnymead quadrangle (Morton and Matti, 2001b; Morton and Miller, 2006). Sediment of the middle member thus continued to accumulate for an unknown — but presumably short_-period after 1.2-1.4 Ma.

This age raises questions about stratigraphic relations among various members of the San Timoteo formation in this part of the Badlands - specifically, relations between (1) the formation's middle and upper members and (2) a third member mapped originally by Morton (1978b). The latter is a sequence of quartzite-clast-bearing conglomeratic rocks in the Redlands quadrangle that Matti and others (2003b) and Morton and Miller (2006) designate as the quartzite-clast member of the San Timoteo formation (unit QTstcq). In the upper part of this unit, Repenning (1987) identified the vole Microtus as the guide taxon for his Olive Dell local fauna. Microtus probably is middle Pleistocene in age (1.3-1.5 Ma). The Microtus-bearing rocks have important implications not only for (a) palinspastic 
reconstruction of the San Andreas Fault (Morton and others, 1986; Morton and Matti, 1993, p. 221; Matti and Morton, 1993, figs. 7G, H) but more prosaically for (b) stratigraphic relations among various lithofacies of the San Timoteo formation.

At issue here is how two distinct sequences of the San Timoteo formation that are about the same age fit into the Badlands stratigraphic succession — given that (1) they are about $10 \mathrm{~km}$ apart, (2) they have markedly different clast assemblages, and (3) they are separated by a fault of undocumented displacement sense and amount. If Albright (1999) and Repenning (1987) both are correct, then the El Casco local fauna near the top of the middle San Timoteo member (Albright, 1999) is about the same age as the Olive Dell local fauna near the top of the quartzite-clast conglomerate member of the formation (Repenning, 1987).

Why is this a problem? Although they are approximately time-correlative, a stratigraphic context for the two sequences has not been demonstrated: they cannot be related within a coherent stratigraphic framework. In the Redlands quadrangle, the quartzite-clast unit is separated from strata directly to the east - presumably the upper member of the San Timoteo formation — by a major northwest-trending fault. Existing mapping (Morton and Matti, 2001b; Morton and Miller, 2006) suggests that the eastern strata are stratigraphically continuous with - and overlie - middle-member beds in the El Casco quadrangle that contain the 1.2-to-1.4 Ma El Casco local fauna. These relations require the following:

1. Fact: In the Redlands quadrangle, strata east of the major fault must be younger than underlying middle-member beds in the El Casco quadrangle (1.2 to $1.4 \mathrm{Ma})$.

2. Consequence: These strata must be younger than San Timoteo beds west of the fault (unit QTstcq) containing the Olive Dell local fauna of Repenning (1987; 1.2 to $1.4 \mathrm{Ma})$.

3. Conclusion: The fault in the Redlands quadrangle juxtaposes older strata on the west (unit QTstcq) against younger strata on the east (unit Qstu). Thus, the fault either has reverse displacement (up on the west) or strike-slip displacement (dextral, most likely). Either slip style has important implications for Pleistocene stratigraphic correlation and paleogeography.

How does this bear on stratigraphic interpretation in the map area? Until a stratigraphicstructural framework is documented for sedimentary rocks in this part of the San Timoteo Badlands, stratigraphic relations among units in the upper San Timoteo formation remain uncertain. Moreover, regional paleogeographic reconstructions for this part of the Badlands succession (for example, Matti and Morton, 1993; Morton and Matti, 1993; Albright, 1999) remain speculative.

\section{Lower Member (Unit Tstl)}

The lower member crops out extensively in the south part of the El Casco quadrangle, where it forms the lower part of the San Timoteo formation of Frick (1921). We include within the lower member three lithologic intervals that - although mappable at 1:24,000 scale — are represented best as informal units of the lower member: (1) a unit dominated by fine-grained sandstone (Tstls); (2) a finegrained unit dominated by mudrock (Tstlf); and (3) a unit of interbedded mudrock and ripple-laminated sandstone (Tstlr).

\section{Sandstone Unit (Unit Tst/s)}

Lithology - The sandstone unit is dominated by one major rock type: sandy rock (silty sandstone, sandstone, and slightly conglomeratic sandstone) that is light-colored, thin- to thick-bedded, well consolidated to indurated, and texturally massive to laminated and cross laminated (fig. 16). Interbedded sparsely with the sandy rocks are thin- to medium-bedded lenticular layers of pebble to small-cobble 
conglomerate containing clasts of San Gabriel Mountains-type crystalline rocks. Siltstone and greenishgray mudstone occur locally (fig. 17).

Stratigraphic boundaries - In the Laborde Canyon area, the sandstone unit abruptly overlies the ripple-laminated unit (Tstlr), but elsewhere the boundary interval is not well exposed. In the Mt. EdenJackrabbit Trail area, we map this boundary as a moderate-angle normal fault of the Laborde Canyon Fault zone. We observed this fault boundary clearly north of Mt. Eden (see figs. 36, 37), but in the Jackrabbit Trail area and southwest of Mt. Eden its location only can be inferred.

The sandstone unit is overlain transitionally by the middle member of the San Timoteo formation. The contact is difficult to map, but is marked by gradually increasing conglomeratic beds that are thicker and laterally more extensive than those typical of the lower member. On the geologic map this contact is located very approximately. In the southeast part of the quadrangle, the lower member buttresses nonconformably against granitoid rock of unit Ktlc that formed a local inselberg (island mountain) rising above the floodplain; lower-member sediment ultimately buried the granitoid inselberg completely. In the southeast corner of the quadrangle, lower-member beds interfinger with a tongue of fine-grained sediment of unit Tstlf.

Depositional origin - Depositional structures and high sand:gravel ratios indicate that the sandstone unit largely is fluvial in origin, probably forming on a braidplain. The depositional setting appears to be lower energy and more distal than that of the overlying middle member of the San Timoteo formation, indicating either greater distance from sediment source areas or, equally likely, lower fluvial-discharge rates and (or) lower sediment availability. The sandstone unit demonstrably interfingers with low-energy lacustrine deposits of the fine-grained unit (Tstlf) and probably with the ripple-laminated unit (Tstlr), although this would have to occur in the subsurface. Paleocurrents generally point southeast and south, and are consistent with streamflows sourced from rocks of San Gabriel Mountains-type located northwest and north of the El Casco quadrangle (Matti and Morton, 1993, figs. 7F, 7G).

Age and correlation - Magnetostratigraphic investigations by Albright (1997, 1999; also Hehn and others, 1996) indicate that the sandstone unit of the San Timoteo formation in the vicinity of Mt. Eden and Jackrabbit Trail is early to late Pliocene (Blancan) in age (about 4.5 Ma to about 3.1 Ma; Albright, 1999, fig. 12). However, the top of the member (and base of the overlying middle member) probably is time transgressive throughout the El Casco quadrangle, as Albright (1999, p. 1290, figs. 12 and 13) notes that at the west edge of the map area the upper part of the lower member has to be older than at least 4.0 Ma in contrast with its $3.5 \mathrm{Ma}$ age in the Mt. Eden area.

\section{Ripple-Laminated Unit (Tstlr)}

The ripple-laminated unit crops out in the south part of the El Casco quadrangle, where it occurs in the basal part of the San Timoteo formation of Frick (1921). The unit is exposed best in roadcuts of Jackrabbit Trail and in the Laborde Canyon area.

Lithology - The ripple-laminated unit consists of two lithologies (fig. 18):

1. yellowish-gray to light olive-gray, well consolidated, ledge-forming, thin- to mediumbedded, very fine-grained to fine-grained sandstone that is texturally and compositionally mature by comparison with sandstones in the underlying Mt. Eden formation. The sandstone beds commonly are ripple-laminated and flat-laminated, and their bases locally have loadand-founder structures (figs. 19, 20, 21).

2. greenish-gray to olive, recessive interbeds of mudstone and calcareous mudstone that are fissile weathering to blocky weathering (figs. 18, 19, 22, 23). These interbeds commonly have mudcracks and raindrop impressions, and locally are gypsiferous. 
Southeast of Laborde Canyon, the ripple-laminated unit is a very distinctive orange-red color (figs. 22 and 23), which probably reflects oxidation or staining by iron-charged groundwater that percolated through the unit during or after its deposition.

Stratigraphic boundaries - The lower contact of the ripple-laminated unit with underlying unit Tstlf is exposed in roadcuts of Jackrabbit Trail and in natural exposures in Laborde Canyon (fig. 7). At both localities, fissile-weathering greenish-gray mudstone of underlying unit Tstlf continues upsection as interbeds in unit Tstlr, and we arbitrarily map the contact between the two units at the first occurrence of ledge-forming ripple-laminated sandstone. For a discussion of how this usage compares to that of previous workers, see the section in appendix 1, "Boundary between the San Timoteo and Mt. Eden formations".

In the Jackrabbit Trail area the contact of the ripple-laminated unit with the overlying lower member (unit Tstls) is not well exposed, but we believe the two units here are separated by a moderateangle normal fault of the Laborde Canyon Fault zone. To the southeast in Laborde Canyon, the contact between the two units appears to be conformable. There, across a stratigraphic interval of a few meters, ripple-laminated and convolute-laminated sandstone of unit Tstlr gives way to sandstone and conglomeratic sandstone of unit Tstls, and mudstone interbeds disappear.

Depositional origin - Depositional structures and rock types in the ripple-laminated unit indicate deposition on a fine-grained distal flood plain marginal to a lake or playa. Gypsiferous mudstone of the underlying fine-grained unit (discussed below) clearly is lacustrine in origin, and the occurrence of this lithology as interbeds between sandstones of unit Tstlr indicates persistence of the lacustrine-playa environment during Tstlr time. Small-scale tabular, trough, and climbing-ripple laminations in the finegrained sandstones suggest low-energy fluvial conditions. Interlayering of mud and ripple-laminated fine sand would be expected at the boundary between lacustrine and floodplain settings. Convolute lamination (figs. 19 and 21) probably reflects load-and-founder structures resulting from dewatering and overburden load, but for some convolute structures, soft-sediment deformation in response to earthquake shaking cannot be ruled out.

We believe that the ripple-laminated unit in the Mt. Eden area represents the initial impulse of sandy sediment derived from crystalline rocks of San Gabriel Mountains-type and deposited on distal parts of the southeast-dipping paleoslope on which the San Timoteo sequence formed; ripple laminations in the member indicate south and southeast-directed streamflows. The southeast-oriented regional braidplain complex replaced local depositional settings that, during deposition of the underlying Mt. Eden formation, radiated from inselbergs of Peninsular Ranges-type rock (discussed below).

Age and correlation - No vertebrate fossils have been reported from the ripple-laminated unit. It clearly is younger than uppermost Miocene-early Pliocene (late Hemphillian-early Blancan) fossils collected from the Mt. Eden formation by Frick (1921) and reexamined by May and Repenning (1982) and Albright (1997, 1999). Magnetostratigraphic data indicate that the ripple-laminated unit is about 4.5 to 4.0 Ma (early Blancan; Albright, 1999, fig. 12; Hehn and others, 1996).

Rocks similar to unit Tstlr occur on the opposite side of San Jacinto Fault in the Reche Canyon area, $30 \mathrm{~km}$ northwest of El Casco quadrangle (unit "Tstlr" of J.C. Matti and others, unpub. geologic mapping, in preparation). Outcrops in Reche Canyon probably have been displaced from those in the Mt. Eden area by strike-slip displacements on the San Jacinto Fault (discussed below).

\section{Fine-Grained Unit (Tst/f)}

The fine-grained unit crops out in the south part of the El Casco quadrangle, where it occurs at two different stratigraphic levels in the sedimentary sequence (fig. 8): (1) as a tongue that interfingers with the sandstone unit of the lower member and pinches out westward (fig. 17), and (2) as an eastward thickening interval that forms the basal part of the formation (figs. 22, 23). 
Lithology - The fine-grained unit consists mainly of light-gray to greenish-brown mudstone and calcareous mudstone that are fissil-weathering to blocky-weathering, and that form recessive slopes prone to downslope movements (figs. 19, 22, 23) although those examples occur in the overlying ripplelaminated unit). These intervals commonly have mudcracks and raindrop impressions, and locally are gypsiferous. The dominant lithology is mudstone, but other lithologies include claystone, silty claystone, siltstone, and very fine biotitic sandstone.

Stratigraphic boundaries - Our inclusion of the fine-grained unit as a basal member of the San Timoteo formation differs from previous workers, who generally include it within the underlying Mt. Eden formation. For a discussion of this problem, see appendix 1, "Boundary between the San Timoteo and Mt. Eden formations".

Depositional origin-Mudrock of the fine-grained unit accumulated under low-energy conditions, and most likely is lacustrine in origin. We envision a playa setting that periodically was flooded with shallow water that persisted long enough to yield suspension deposits of fine clay and silt. Shallow conditions are suggested by mudcracks and by periodic sandy and silty interbeds that probably are fluvial; evaporative conditions are suggested by gypsum that occurs in the mudstone as needles, clots, and blades. Pinchout westward and northwestward of both the basal and higher mudstone intervals indicates that the lacustrine-playa setting was confined to the southeast part of the regional paleoslope; lake expansion probably would occur only when fluvial-discharge rates were large enough to allow the lake strandline to migrate up the paleoslope.

Age and correlation-Magnetostratigraphic investigations by Albright $(1997,1999)$ indicate that the fine-grained unit of the San Timoteo formation probably is early Pliocene (early Blancan) in age (about 5.0 to 4.5 Ma; Albright, 1999, figs. 8, 12). However, complications exist in the magnetostratigraphic record along Jackrabbit Trail (see Albright, 1999, fig. 8, the stratigraphic interval spanned by paleomagnetic samples 143-143B), and the age for the fine-grained unit here may not be completely resolved (also see problems in local lithostratigraphic correlation, discussed in appendix 1, "Boundary between the San Timoteo and Mt. Eden formations").

\section{Mt Eden Formation of Frick (1921), Revised}

The "Mt. Eden formation of Frick (1921)" occurs in the southeast corner of the El Casco quadrangle, in the vicinity of Mt. Eden. Although Frick did not specify a type section, the area around the Mt. Eden massif contains partial stratigraphic sections that, together, provide essential reference sections for the formation.

\section{Original Definition}

Frick (1921, p. 335) applied the name "Eden Formation" to sedimentary rocks in his "lower San Timoteo deposition" (Frick, 1921, p. 283, p. 335, also referred to these as the "Eden beds"). Frick (1921, p. 335-336) provides the following description of the formation [text in square brackets indicate comments by us]:

"Throughout a considerable area, in the southwest quarter of the Badlands, deposits characterized by greater induration and the prevalence of calcareous bluish and greenish shales appear unconformably underlying the San Timoteo beds. They are designated here as the Eden Formation $* * *$

In its most northwesterly extension the Eden occurs in two low outcroppings of northdipping, blue shales at the base of the west wall, a half mile above the mouth of Outlaw Cañon [the unnamed large canyon directly west of Jackrabbit Trail]. At the opposite side of the same cañon the formation may be seen in the north-and-south-dipping series in the cut for the new Rabbit Grade [Jackrabbit Trail]....Southeastward the outcroppings of the Eden 
Formation may be followed for some five miles across Eden Mountain, Laborda Cañon, and Lamb Cañon to the vicinity of the coarse underlying arkosics of the San Jacinto foothills and Lamb Mountain. The largest and finest exposures are to the immediate east of Rabbit Grade, in the region about the western base and upon the higher northwestern corner of the mountain whose name has been given to the formation. There faulted ledges of indurated Eden sands and shales intermixed in lower planes with limestone breccia rest against the metamorphic limestone of the basement complex. These ledges have yielded much of the best [fossil] material. They extend a fifth of a mile along the mountain face, and are capped by bluish shale slopes, thickly grown with brush. To the immediate east they [Eden beds] disappear in the neighborhood of an overreaching arm of the San Timoteo formation. [In the SW part of Section 24 (T. 3 S, R. 2 W.), our map interprets this "overreaching arm of the San Timoteo formation" to be in fault contact with the "Eden formation"].

The Eden beds in the Rabbit Cut lie in a sharp northeast- and southwest-dipping anticline unconformably overlain by similarly dipping beds of the San Timoteo deposit. The section is believed to represent the more general structure of the region. In the vicinity of the mountain itself the strata are much disturbed, the dips tending away from the schists. Immediately east of the Rabbit Cut the northeast dip is replaced by a northwestern. A particularly well marked break occurs in the 150-foot cliff in the hillside opposite the northwest corner of Eden, a forty foot ledge of dark indurated sandstone intervening between the typical Eden shales and overlying San Timoteo. A similar indurated sandstone may be seen both a quarter mile to the south, capping an end of one of the typically low-lying blue ridges, and again above the blue Eden shales in the Rabbit Grade cut. The aspect of unconformity between the two San Timoteo formations [Mt. Eden formation and San Timoteo formation] has been generally heightened by faulting."

From this description we conclude that Frick (1921) characterized his "Eden Formation" using the following criteria [square brackets denote our interpretation of Frick's statements]:

1. "bluish and greenish shales" [greenish to greenish-gray slope-forming mudrock];

2. "limestone breccia" [white nodular and lenticular freshwater limestone];

3. sandstone of various kinds, including an interval of "dark indurated sandstone" that Frick (1921, p. 336) believed to occur in the upper part of the unit at both Mt. Eden and Jackrabbit Trail;

4. an unconformable contact between the Mt. Eden formation and the San Timoteo formation (see Frick, 1921, p. 286, 335, 337);

5. stratigraphic transition southeastward and downsection into redbeds of his "Potrero Creek deposits" [distinctive reddish sandy and conglomeratic rocks in the Beaumont and San Jacinto quadrangles].

\section{Revisions by Fraser (1931)}

In a report describing the geology directly southeast of the El Casco quadrangle, Fraser (1931) introduced stratigraphic revisions that clarified some of Frick's interpretations but confused others.

1. Because the name "Eden" is preempted by its application to Ordovician rocks elsewhere in the United States, Fraser renamed Frick's "Eden Formation" to "Mt. Eden formation" (Fraser, 1931, p. 512). We follow this nomenclatural revision.

2. To strata directly southeast of the El Casco quadrangle that Frick assigned to his "Potrero Creek deposits", Fraser (1931, p. 511-512) applied the name "Red Bed Member of the Mt. Eden 
formation". These rocks demonstrably occupy the same stratigraphic interval as the type Mt. Eden formation (Matti and others, unpublished mapping); therefore, we accept their inclusion within that unit as advocated by Fraser.

3. Fraser (1931) applied the name "Mt. Eden formation" (without member designation) to all remaining Tertiary sedimentary rocks from the top of his "Red Bed Member" northward to the Beaumont Plain (Fraser, 1931, p. 513 and geologic map). This last step clearly conflicts with Frick's original stratigraphic interpretations, because much of this stratigraphic interval clearly can be mapped westward into strata Frick (1921) assigned to his San Timoteo formation (figs. 22, 23; Matti and others, unpub. mapping). Thus, Fraser applied the name "Mt. Eden" to a broader lithologic sequence than Frick (1921) originally intended. We do not adopt Fraser's interpretation for this stratigraphic interval.

\section{Usage of This Report}

We apply the name "Mt. Eden formation of Frick (1921)" to approximately the same sedimentary sequence that Frick (1921, p. 335) relegated to his "lower San Timoteo deposition", although we interpret the unit's upper boundary differently than Frick (discussed in appendix 1). In the vicinity of Mt. Eden, the formation occurs in the core and on both flanks of the San Timoteo Anticline. Frick (1921) did not break out individual members of his "Mt. Eden formation", although later workers have separated the sequence into various mappable units. We map four members of the formation (figs. $7,8)$ :

\section{Heterogeneous Member (Unit Tmeh)}

The heterogeneous member crops out in the Mt. Eden area, but is absent in Laborde Canyon where the unit is missing presumably due to facies changes. North, west, and south of Mt. Eden the heterogeneous member forms the uppermost part of the formation.

Lithology - The heterogeneous member includes several distinct lithologies, two of which Frick (1921) emphasized in his original characterization of the "Eden formation": (1) greenish-gray mudstone that weathers into chips and thin wafers ("calcareous bluish and greenish shales" of Frick, 1921, p. 335; our figs. 22, 23); and (2) white, nodular to lenticular beds of limestone ("limestone breccia" of Frick, 1921, p. 335; our fig. 24). Additional lithologies include (3) greenish-gray siltstone and fine biotitic sandstone (fig. 25), (4) arkosic and lithic sandstone and conglomeratic sandstone (figs. 26A, 26B) similar to rocks in the underlying arkosic and lithic member (unit Tmea), and (5) well-indurated ledgeforming sandy rock that occurs in the member on the north slopes of Mt. Eden (referred to in caption for fig. 33). These lithologies occur in varying proportions throughout the heterogeneous member, although the finer grained rock types appear to predominate in the upper part of the unit adjacent to its contact with the overlying fine-grained unit of the San Timoteo formation (figs. 22, 23). The sandy and conglomeratic rocks contain angular to subangular particles of aplite, schist, gneiss, metaquartzite, marble, and granitoids (figs. 26A, 26B) - all derived from crystalline rocks of Peninsular Ranges-type. We observed no particles of Transverse Ranges-type in the unit. Most of the vertebrate fossils collected by Frick (1921) are from the heterogeneous member where it crops out on the north slope of Mt. Eden (referred to in caption for fig. 32).

Stratigraphic boundaries - West and south of Mt. Eden, the heterogeneous member rests conformably on sandy and conglomeratic rock of the arkosic member (unit Tmea; figs. 7, 8). The contact is fairly abrupt, and is marked by the initial occurrence of greenish-gray mudstone of the heterogeneous member. On the north slope of Mt. Eden the member locally rests directly on crystalline rock, and the lower contact here is a buttress unconformity. 
The stratigraphic makeup of the Jackrabbit Trail-Mt. Eden area differs significantly from that in the Laborde Canyon area: the heterogeneous unit (Tmeh) in the western area is missing to the east, either (1) because of facies changes, stratigraphic pinchouts, and (or) stratigraphic onlap, or (2) because the heterogeneous member in the Laborde Canyon area is cut out by faulting (discussed below). Structural elimination seems unlikely, however, and we attribute differences in stratigraphic sequence throughout the Mt. Eden district to nonstructural factors.

We map the boundary between the heterogeneous member and overlying lithostratigraphic units differently than did Frick (1921) and later workers (English, 1953; Shuler, 1953; May and Repenning, 1982). This difference and its implications are discussed in appendix 1.

Depositional origin-Mudstone of the heterogeneous member (figs. 22, 23, 24) accumulated under low-energy conditions, and most likely has a lacustrine origin similar to that of mudstone in the overlying fine-grained unit of the San Timoteo formation. For both units, we envision a playa setting that periodically was flooded with shallow water that persisted long enough to yield suspension deposits of clay, silt, and very fine sand. Limestone interlayered with the mudstone (fig. 24) probably is lacustrine, but some limestone bodies that have irregular nodular and concretionary shapes may be travertine deposits associated with hot or cold springs within the playa or along its margins. Fine biotitic sandstones and siltstones (fig. 25) probably are low-energy fluvial deposits. Coarser grained sandy and conglomeratic rock (figs. 26A, 26B) locally have channelate beds and cross-stratification that indicate a higher energy fluvial genesis. Clast compositions and paleocurrent indicators indicate sediment derivation exclusively from crystalline rocks of Peninsular Ranges-type.

Age and correlation-Most of the vertebrate fossils collected by Frick (1921, p. 337-409) from the Mt. Eden formation were collected from beds of the heterogeneous member on the north slopes of Mt Eden (the "Eden ledges" of Frick, 1921, p. 337-338, p. 339, locality 3269). The fossils and their age and correlation were reevaluated by May and Repenning (1982), Reynolds and Reeder (1991, p. 46), and Albright (1997, 1999), and are thought to be uppermost Miocene in age (late Hemphillian Land Mammal age). Albright (1997, 1999; also see Hehn and others, 1996) conducted magnetostratigraphic investigations within the heterogeneous member that indicate an age range of 5.7 Ma to about 4.5 Ma; the member thus ranges in age from uppermost Miocene to earliest Pliocene.

\section{Arkosic and Lithic Member (Unit Tmea)}

The arkosic and lithic member constitutes most of the Mt. Eden formation. The member crops out extensively west of Mt. Eden in the core of the San Timoteo Anticline, and south of Mt. Eden where it is disrupted by the Moreno Valley strand of the San Jacinto Fault and by the Mt. Eden Fault. The member also crops out on the summit of Mt. Eden itself - confirming that the Mt. Eden basement inselberg was completely buried not only by encroaching sediment of the San Timoteo formation but even earlier by sediment of the Mt. Eden formation presumably derived from Peninsular Ranges-type basement rock south of the San Jacinto Fault zone. The member also crops out extensively in lower Laborde Canyon, but there its lithologic character differs somewhat from that farther to the west.

Lithology - At any one location, the arkosic and lithic member is fairly homogeneous in lithology (fig. 27), although subtle facies changes occur from west to east. In the Mt. Eden area the unit tends to be more brownish than in the Laborde Canyon area, where rock tends to be more grayish. We attribute these color differences to the greater amount of metamorphic particles in the Mt. Eden area than in the Laborde Canyon area, where granitoid particles (quartz, feldspar, biotite, granitoid lithics) predominate. Traced from Laborde Canyon to the summit of Mt. Eden, predominantly grayish beds progressively are interstratified with light-brownish beds, suggesting a facies change from granitoiddominated to metamorphic-dominated sources. In all instances (figs. 28, 29, 30), the rock is well consolidated, is recessive and slope forming rather than ledge forming, is thin bedded to very thick bedded to crudely stratified, ranges from coarse sandstone to conglomeratic sandstone, and contains 
angular to subrounded particles derived exclusively from crystalline rocks of Peninsular Ranges-type (aplite, gneiss, metaquartzite, marble, schist, and granitoids; figs. 29, 30). We observed no particles of Transverse Ranges-type in the unit.

Stratigraphic boundaries - Stratigraphic relations between the arkosic member of the Mt. Eden formation and other map units vary throughout the El Casco quadrangle. Fundamentally, the unit was deposited nonconformably on crystalline basement rocks of Peninsular Ranges-type, represented locally by the Mt. Eden massif. This relationship is seen best adjacent to the inselberg, where unit Tmea locally buttresses depositionally against the crystalline rocks. Ultimately, the Mt. Eden inselberg was completely buried by encroaching sediment of the arkosic member, as demonstrated by the thick sequence of unit Tmea that rests depositionally on the summit of the inselberg. This suggests that much of the Peninsular Range-derived sediment in the arkosic member was sourced from south of the San Jacinto Fault zone, rather than from the Mt. Eden inselberg itself. This conclusion is consistent with sparse paleocurrent indicators we have measured, which typically indicate streamflows toward the northwest to northeast.

Southeast of the El Casco quadrangle, the arkosic member of the Mt. Eden formation overlies redbeds of the Potrero Creek deposits of Frick (1921, p. 338-339) (red bed member of the Mt. Eden formation of Fraser, 1931). Our mapping in the Beaumont, Lakeview, and San Jacinto quadrangles (J.C. Matti and others, unpub. mapping; Morton and Matti, 2001a) indicates that the arkosic member interfingers with the redbeds as well as overlying them (fig. 8).

Depositional origin - The arkosic and lithic member of the Mt. Eden formation mainly is fluvial in origin, but massive depositional fabrics locally may reflect deposition by overland flow and (or) by colluvial processes involving downslope movement under the influence of gravity and sheetwash.

Age and correlation - Where it crops out in roadcuts of Jackrabbit Trail, youngest parts of the arkosic member appear to be no younger than about $6 \mathrm{Ma}$; in this section, Albright determined a magnetostratigraphic age of about $6.3 \mathrm{Ma}$ for somewhat older beds, and collected microvertebrate fossils indicating a late Miocene age (see Albright, 1999, p. 1284, fig. 12). The upper part of the arkosic and lithic member in the Mt. Eden area thus is late Hemphillian in age (about $6 \mathrm{Ma}$ ), but probably ranges downward to as old as 7 or $8 \mathrm{Ma}$ considering the thickness of the unit in lower Laborde Canyon and areas to the southeast.

\section{Boulder Conglomerate Member (Unit Tmeb)}

Although some workers have mapped the boulder conglomerate member of the Mt. Eden formation as granitoid basement rock (for example, Shuler, 1953, p. 25-27, figs. 28, 37-40; Blacet, 1960), a sedimentary origin for the unit was recognized by Larsen (1962, p. 25-32) and by Morton (1972; Morton and Matti, 2001b, their "boulder breccia" unit).

Lithology - The boulder conglomerate member consists of lenticular bodies of monolithologic conglomerate. Particle size ranges from pebbles to boulders as much as $6 \mathrm{~m}$ in dimension that are angular to rounded (figs. 22, 31; Larsen, 1962, figs. 14-16). Clasts exclusively are hornblende-biotite tonalite identical to tonalite of Lamb Canyon (unit Ktlc). Like Larsen (1962) and Morton and Matti (2001b), we conclude that clasts in the boulder conglomerate were derived from that bedrock unit.

Depositional origin -Depositional textures, bedding geometry, clast compositions, and stratigraphic relations indicate that the boulder conglomerate member was deposited as debris flows and (or) as a long-runout rock avalanche (sturzstrom) sourced from bedrock outcrops of unit Ktlc. The deposits were shed southward from the Mt. Davis area onto the alluvial valley floor where the arkosic member of the Mt. Eden formation was accumulating. This contrasts with sediment sources for the arkosic and lithic member (unit Tmea) which appears to have been derived from sources south of the San Jacinto Fault (discussed above); thus, this part of the Mt. Eden formation received sediment sourced from north and south of the future fault. 
Age and correlation - The boulder conglomerate member occurs in the upper Miocene (late Hemphillian) upper part of the arkosic and lithic member of the Mt. Eden formation (fig. 22), and probably is on the order of about $6.3 \mathrm{Ma}$ or slightly younger (see age of arkosic member, discussed above).

\section{Sandstone Member (Unit Tmes)}

We map the sandstone member of the Mt. Eden formation only in a fault-bounded wedge on the south side of Mt. Eden. It occurs at the top of the arkosic member of the Mt. Eden formation.

Lithology - The sandstone member forms a discontinuous, thin interval of lithified, ledgeforming, light-gray, laminated to cross-laminated and crossbedded, moderately sorted to well sorted sandstone and slightly conglomeratic sandstone with minor granule conglomerate. Grains and clasts are granitic (quartz, feldspar, biotite, granitoid lithics, aplite) and minor metamorphic rocks.

Stratigraphic boundaries - The sandstone member of the Mt. Eden formation is underlain abruptly by the arkosic and lithic member of the formation (unit Tmea) and overlain equally abruptly by the fine-grained unit of the San Timoteo formation (unit Tstlf). One or the other (or both) of these boundaries may be an unconformity, judging from the discontinuous nature of the sandstone member. Alternatively, one or both boundaries could be a bedding-plane fault. We cannot rule out faulting, but our map shows the boundaries as stratigraphic contacts.

Depositional origin - The sandstone member of the Mt. Eden formation is a fairly clean wellsorted sandstone body that was deposited by fluvial processes. Its stratigraphic position between the texturally and compositionally more diverse arkosic member (Tmea) and heterogeneous member (unit Tmeh) suggests that a more homogeneous alluvial environment temporarily established itself on the Peninsular Ranges landscape on which other members of the Mt. Eden formation accumulated under the influence of local alluvial and playa settings.

Age and correlation - The sandstone member is uppermost Miocene (upper Hemphillian), given its stratigraphic position between two map units that are about that age (arkosic and lithic member of the Mt. Eden formation and fine-grained member of the San Timoteo formation).

\section{Depositional History of the San Timoteo and Mt. Eden Formations}

Our geologic mapping in the El Casco, Beaumont, and San Jacinto quadrangles leads to a stratigraphic and depositional model in which the boundary zone between the Mt. Eden and San Timoteo formations marks a major transition between contrasting paleogeographic regimes. We conclude that differences in lithostratigraphic interpretation across the formational boundary (Frick, 1921; English, 1953; Shuler, 1953; Larsen, 1962 Matti and Morton, 1975, 1993; Albright, 1999; this report) reflect not only geologic complexity and outcrop ambiguity but also transitional lithologic changes that accompanied this major paleogeographic transition.

\section{Depositional History, Mt. Eden Formation}

The Mt. Eden formation accumulated on a landscape where inselbergs like ancestral Mt. Eden and Mt. Davis stood above lowlands on which late Miocene sediment was deposited. This former landscape must have looked much like the modern landscape around Perris, Hemet, and San Jacinto, where inselbergs of Peninsular Ranges rock stand above lowlands on which sediment currently accumulates by fluvial, sheetwash, and colluvial processes. Sediment in the Mt. Eden formation was derived from the Peninsular Ranges uplands, as indicated by clast compositions (granitoid and metamorphic rock types of obvious Peninsular Ranges-type), paleocurrent indicators (clast imbrications indicating stream flow away from known and inferred Peninsular Ranges inselbergs and highlands), and clast angularity (indicating short transport distance). 


\section{Depositional History, San Timoteo Formation}

The transition from the Mt. Eden formation to the San Timoteo formation marks a major paleogeographic shift from localized depositional centers receiving sediment from nearby Peninsular Ranges uplands (Mt. Eden setting) to a major braidplain system (San Timoteo setting). The braidplain developed on a regional paleoslope inclined to the southeast, as evidenced by paleocurrent indicators (clast imbrications, cross bedding) and by facies relationships. San Timoteo sediment was sourced from crystalline rock of San Gabriel Mountains-type, as indicated (in the lower member) by clasts of distinctive hypabyssal rock and dike rock of various kinds along with nondiagnostic Transverse Rangestype granitoids, and (in the middle member) by clasts of Pelona Schist, Lowe Granodiorite, and mylonitic rocks from the upper plate of the regionwide Vincent Thrust. All of these rock types occur in the San Gabriel Mountains proper. Missing from the San Timoteo formation, however, are clasts of metasedimentary rock, granulitic rock, and "black-belt" mylonite that occur along the southeast margin of the San Gabriel Mountains (Morton and Matti, 1987). For this reason, Matti and Morton (1993) proposed that sediment in the San Timoteo Formation was derived not from the San Gabriel Mountains proper but from similar rocks that apparently formed a highland northwest of the El Casco quadrangle in the region now occupied by the low-standing San Bernardino Valley (see discussion by Morton and Matti, 1993). Upper-plate rocks of this highland were eroded away and transported southeastward onto the San Timoteo braidplain. Ultimately, stream erosion excavated through the Vincent Thrust and exposed Pelona Schist, the first clasts of which occur within the middle member of the San Timoteo formation.

The San Timoteo floodplain was a network of braided sandy and gravelly streams separated by overbank areas of finer sandy and muddy sediment. For parts of this history, the streams emptied into standing bodies of water (ponds and lakes) that are represented now by greenish-gray mudrock of the fine-grained and ripple-laminated units (units Tstlf and Tstlr). The mudrock intervals thicken significantly southeastward and, in the Beaumont quadrangle, expand into a thick sequence of finegrained rock that forms much of the lower part of the San Timoteo formation (figs. 22 and 23; J.C. Matti and others, unpub. geologic mapping in preparation). This body of lacustrine and (or) playa mudrock buttresses against rocks of Peninsular Ranges-type, including those of the San Jacinto Mountains massif, suggesting that the latter formed a highland that ponded streamflows of the San Timoteo braidplain.

Magnetostratigraphic data (Albright, 1999) indicate that braidplain deposition continued for at least 3.5 Ma from earliest Pliocene through early Pleistocene time, and led to a geographically widespread sediment blanket that extended from western San Gorgonio Pass to perhaps as far west as the Jurupa Mountains region of western Riverside County. There, exotic pebbles of San Gabriel Mountains-type basement rock (including Pelona Schist) occur as lags perched on Peninsular Rangestype rock of the Jurupa Mountains. Morton and Matti (1989) thought that this "vanished fan deposit" was Pliocene in age, and Matti and Morton (1993) interpreted this feature as a vanished remnant of the San Timoteo formation that was displaced away from the San Timoteo Badlands region by about $24 \mathrm{~km}$ of right slip on the San Jacinto Fault.

In early Pliocene time sediment of the San Timoteo braidplain complex encroached southeastward toward Peninsular Ranges inselbergs and highlands. The San Timoteo deposits gradually buried the inselbergs until, ultimately, many of them were entirely overlapped by the encroaching braidplain complex. Granitic outcrops such as those on Mt. Eden and on Mt. Davis south of Beaumont only now are being exhumed as erosion by late Quaternary streams strips away sedimentary material of the San Timoteo Badlands succession. Buried inselbergs similar to Mt. Eden no doubt lie beneath much of the terrane now covered by sedimentary materials of the San Timoteo Badlands, but their presence can be detected only by geophysical techniques (for example, Langenheim, this report; Langenheim and 
others, 2005, 2006) or by borings that penetrate basement rock at unexpectedly shallow subsurface depths (for example, the Moreno boring on sheets 1 and 2).

\section{Crystalline Basement Rocks}

In the vicinity of the El Casco quadrangle, crystalline basement rocks represent three distinctive packages that are widespread in southern California (fig. 2):

- crystalline rocks of Peninsular Ranges-type

- crystalline rocks of San Gabriel Mountains-type

- crystalline rocks of Mojave Desert-type

Rocks of Peninsular Ranges-type and San Gabriel Mountains-type crop out in the El Casco quadrangle and are concealed in the subsurface. Rocks of Mojave Desert-type are represented only as pebbles and cobbles that occur in certain sedimentary and surficial map units; this regional suite crops out in the San Bernardino Mountains north of the map area (fig. 2).

\section{Crystalline Rocks of Peninsular Ranges-Type}

These rocks crop out in southern and northeastern parts of the El Casco quadrangle, and are generally similar to rocks elsewhere in the Peninsular Ranges Province (in the sense of Jahns, 1954).

Granite of Mt. Eden - A body of pale-brown, coarse-grained monzogranite (unit Kmeg) occurs on the south flank of Mt. Eden. The unit was mapped by Beyer (1959) and MacLeod (1961) as alaskite, and is characterized by its distinctive leucocratic garnet-muscovite composition. Age relations with tonalite of Lamb Canyon (unit Ktlc) are not known, but unit Kmeg probably is older based on its pervasive foliation and based on sequencing relations elsewhere in the San Jacinto Mountains.

Tonalite of Lamb Canyon - A distinctive body of biotite and hornblende-biotite tonalite (unit Ktlc) named for exposures at the head of Lamb Canyon in the Beaumont Quadrangle occurs northeast of Mt. Eden. The unit forms outcrops covered by rounded boulders, and consists of homogeneous white to light-gray, medium- to coarse-grained tonalite that is massive to slightly foliated and in most places contains large euhedral sphene crystals; some outcrops are biotite bearing, others contain both biotite and hornblende. This rock originally was described by Fraser (1931), and is part of the Cretaceous San Jacinto intrusive complex described by Hill (1984, 1988; Hill and Silver, 1988; Hill and others, 1988). Zircons from rock at the head of Lamb Canyon have $\mathrm{Pb} / \mathrm{U}$ ages of $94 \mathrm{Ma}$; sphene yields a $\mathrm{Pb} / \mathrm{U}$ age of 92.8 Ma (W. Premo, written commun. to D.M. Morton, 2002). The unit originally was completely buried by the San Timoteo formation of Frick (1921) but now is being exhumed by headward erosion related to Laborde Canyon and Lamb Canyon.

Metasedimentary rocks - In the vicinity of Mt. Eden, plutonic rocks have intruded prebatholithic metasedimentary rocks (unit $\mathrm{ms}$ ) that consist of pendants and screens of quartzofeldspathic biotite gneiss, coarse-grained white to light-gray limestone marble, and minor quartzite; larger bodies of marble are mapped separately (unit $\mathrm{m}$ ). Locally these rocks are intermingled with intrusive granitoid rock to form migmatitic structures. These rocks represent metamorphosed sedimentary rocks whose protolith age probably is Paleozoic.

\section{Crystalline Rocks of San Gabriel Mountains-Type}

These rocks crop out in the northeastern corner of the El Casco quadrangle. They generally are similar to rocks in the southeastern San Gabriel Mountains that form the upper plate of the regionwide Vincent Thrust (Ehlig, 1968, 1981, 1982; Morton, 1975; Matti and others, 1985, 1992a). We have mapped them throughout the greater San Gorgonio Pass region, where they invariably occur north of the 
Banning Fault (Matti and others, 1992a; Matti and Morton, 1993). In the El Casco quadrangle we recognize two map units of San Gabriel Mountains-type:

Foliated crystalline rocks - This unit (fcr) is compositionally and texturally heterogeneous. The rock mainly is mesocratic, but mafic zones are common and leucocratic rocks occur locally. The rock generally is granodioritic to tonalitic in composition. Biotite typically occurs without hornblende, although the latter occurs locally. The rock mainly is equigranular, averaging medium grain size but ranging from fine to coarse. Large potassium-feldspar crystals occur in some outcrop sequences, and we interpret these as deformed phenocrysts (porphyroclasts) in a rock fabric that originally was porphyritic.

The most distinctive attribute of unit fcr is penetrative fabrics that range from textural foliation to cataclastic and mylonitic foliation to gneissose compositional layering. In the El Casco quadrangle, gneissose zones consist of greenish colored, chloritic, biotite-rich layers alternating with quartzofeldspathic layers, some of which are very quartz rich. Some gneissose zones appear to be screens and pendants of prebatholithic metamorphic rock intermingled with the foliated plutonic rock; other zones may represent highly deformed granitoids that have developed mafic and felsic gneissose layering. Still other gneissose zones appear to result from intermingling of mafic plutonic rock and leucocratic dike rocks. The gneissose layers locally have small-scale tight to isoclinal folds having hingeline lineations oriented parallel to mineral-aggregate lineations in the foliated and mylonitic rocks.

Judging from their composition and relict textures, rock in unit fcr is plutonic in origin.

Throughout the unit, however, pervasive foliation and gneissose layering indicate that the plutonic rock has been transformed into high-strain metamorphic rocks by ductile deformation and recrystallization during or subsequent to their intrusive origin. On a regional basis, this is characteristic of rock that overlies the Vincent Thrust (Morton, 1975; Ehlig, 1982).

Diorite-In the northeast corner of the El Casco quadrangle, a body of texturally massive to slightly foliated, medium- to coarse-grained biotite-hornblende diorite (unit \}d) appears to intrude mylonitic rocks of unit fcr. Intrusive relations between the two units are ambiguous, however. Unit \}d appears to contain xenoliths of unit fcr, and locally appears to crosscut that unit. In addition, unit $\} d$ is less deformed than the foliated and mylonitic unit fcr, and overall appears to be more oval in body plan rather than sheetlike as are intervals of unit fcr. Cross-cutting relations between the two units locally are contradictory, however, and fabric contrasts between them cannot necessarily be used to demonstrate sequencing relations. The dioritic rocks could be older than unit fcr and be less deformed due to their lower quartz content; quartz-rich rocks of unit fcr could be more strongly deformed even though they may be younger.

\section{Structural Geology}

Cenozoic geologic structures (faults, folds) in the El Casco quadrangle formed within the San Andreas Fault system (Crowell, 1981) - a family of geologic structures in southern California that interact as an integrated complex (Matti and others, 1992a; Matti and Morton, 1993).

\section{Folds}

\section{San Timoteo Anticline}

A major northwest-trending anticline is traceable throughout much of the San Timoteo Badlands (fig. 13), affecting all rock units in the Badlands sequence (English, 1953; Shuler, 1953; Morton and Miller, 2006). The anticline is asymmetric, with a shallowly dipping northeast limb and a southwest limb that dips as steeply as 65 degrees. For much of its extent the fold plunges gently to the northwest, and its hinge line is broadly curved and locally sinuous. 
The distribution and geometry of the San Timoteo Anticline suggest that its genesis may be linked in part to uplift of crystalline rocks exposed in the Mt. Eden massif. From Jackrabbit Trail, the anticline axis extends southeast to the massif and, although the intervening Mt. Eden Fault locally complicates relations, the fold axis can be recognized in sedimentary materials atop the inselberg in its summit area (fig. 13; also see fig. 33). From there, the fold continues to the south edge of the El Casco quadrangle and extends southeastward into the adjacent Lakeview and San Jacinto quadrangles (figs. 13, 33; see Morton and Matti, 2001a, although they do not show the fold's axial trace). In all these areas, the crest of the anticlinal fold coincides with a ridge of crystalline basement rocks like those in the Mt. Eden massif. This ridge is expressed as a NW-trending high in the regional isostatic gravity signature (fig. 42, and map sheet 3); the low is recognizable northwest of the Mt. Eden massif even though no crystalline rocks are exposed there, suggesting that the basement ridge continues in the subsurface beyond the massif.

Basement rocks of Mt. Eden themselves do not appear to be folded: ductile metamorphic foliations throughout the massif retain their homoclinal northeast dips, and we have not observed young, brittle microstructures that presumably would be required to accommodate distributive strain in basement rocks deformed by a shallow-level late Neogene fold. Instead, the crystalline rocks appear to have been uplifted passively, and the sedimentary materials that originally covered them appear to have been drape-folded across the flanks of the rising basement core. During this process, sedimentary materials on the fold's north limb apparently detached from the growing fold along the Laborde Canyon Fault zone (discussed below). Locally, the fold's axial plane appears to have been truncated and displaced to the northeast by low-angle faults of the Laborde Canyon zone.

\section{Fold Age}

To reconstruct an age for deformation associated with the San Timoteo Anticline we integrate two data sets: structural relations between the San Timoteo formation and the sedimentary deposits of Live Oak Canyon, and paleontologic and paleomagnetic data (Albright, 1999).

\section{Inception Age}

The San Timoteo Anticline affects to the same degree all members of the San Timoteo formation, requiring that folding began after sediment in these units accumulated. Youngest strata involved in the fold are in the upper part of the middle member (unit QTstm), dated by paleomagnetic measurements and by fossil vertebrates at $\sim 1.4 \mathrm{Ma}$ (Albright, 1999). Northwest of the El Casco quadrangle, younger beds of the formation (its upper member, unit Qstu) are strongly deformed also (Morton and Matti, 2001b; Matti and others, 2003b; Morton and Miller, 2006). These strata are younger than 1.4 Ma, but their exact age has not been determined. Moreover, it is not clear that their structural attitude can be associated with the San Timoteo Anticline because its northwestward extent beyond the El Casco quadrangle has not been documented (the fold axis here is not depicted by Morton and Matti, 2001b, or by Morton and Miller, 2006). As best we can determine, warping associated with the San Timoteo Anticline initiated sometime after 1.4 Ma.

How much younger than 1.4 Ma can be deduced from stratigraphic and structural relations between the folded San Timoteo formation and beds of the overlying sedimentary deposits of Live Oak Canyon. The latter occur entirely northeast of the San Timoteo Anticline, and the succession is tilted gently to the northeast presumably as part of the fold's northeast limb. Dips in the Live Oak Canyon succession are shallower than those in the San Timoteo formation, and are progressively more shallow northeast away from the fold crest. We interpret this to mean that, although Live Oak Canyon beds have been tilted by the anticlinal fold, they have not been deformed as severely as beds of the San Timoteo formation. Moreover, the Live Oak Canyon beds do not wrap around the NW-plunging nose of the San 
Timoteo Anticline as do members of the San Timoteo formation; instead, Live Oak Canyon strata are confined to the fold's northeast limb. These structural relations suggest that the anticline began to develop prior to initial deposition of Live Oak Canyon beds, thereby restricting their accumulation to a structural downwarp that developed northeast of the growing anticlinal fold (see Rewis and others, 2006, Rewis and others, 2006, figs. 5 and 6).

The Live Oak Canyon succession probably is as old as 1.2 Ma. The oldest exposed beds occur on the north side of San Timoteo Canyon, where Albright (1999, figs. 4, 11) reports a fossil mammoth that may be as old as $900 \mathrm{ka}$ to $1.0 \mathrm{Ma}$ (Albright, 1999, fig. 14). Subsurface occurrences of Live Oak Canyon strata to the northeast are stratigraphically beneath the mammoth locality (e.g., Rewis and others, 2006, figs. 5 and 6, their unit "Qsl"), and therefore are somewhat older. Given (1) that beds of the upper San Timoteo member are 1.4 Ma or younger, (2) that a depositional hiatus probably accompanied the initial phase of anticlinal folding and associated landscape evolution, and (3) that basal beds of the Live Oak Canyon succession probably are not much older than $900 \mathrm{ka}$ to $1.0 \mathrm{Ma}$, then the San Timoteo Anticline probably originated in a narrow time window between about 1.4 Ma and about 1.1 to 1.2 Ma.

\section{Folding Synchronous with Live Oak Canyon Deposition}

Oldest beds of the Live Oak Canyon sequence dip slightly more steeply than beds stratigraphically higher in the sequence, which suggests that the San Timoteo Anticline was actively developing as Live Oak Canyon deposits accumulated. Tilted beds include the Shutt Ranch vertebrate local fauna dated at about 780 to $990 \mathrm{ka}$ (middle Pleistocene, Irvingtonian-II; Reynolds and Reeder, 1986; Albright, 1999; our fig. 11 indicates the approximate location of the Shutt Ranch local fauna). Live Oak Canyon beds spanning the Brunhes-Matuyama magnetic reversal $(780 \mathrm{ka})$ also are tilted away from the anticline, indicating that folding continued into the middle Pleistocene. However, youngest Live Oak Canyon beds are only slightly tilted to the northeast, suggesting that the rate of warping on the San Timoteo Anticline may have slowed by about $700 \mathrm{ka}$.

\section{Has Folding Terminated?}

Stratigraphic and structural relations between the San Timoteo Anticline and unconsolidated deposits of the Qvo and Qo series in the San Timoteo Canyon drainage suggest that anticlinal warping may have continued until as recently as a few hundred thousand years b.p. For deposits of the Qvo series we do not have many structural-orientation measurements, but those we do have suggest that the deposits are variably tilted to the north and northeast. By contrast, alluvium of the Qo series does not appear to be back-tilted; in fact, these deposits lap unconformably against highground underlain by Qvo alluvium, and fill paleovalleys eroded into the latter. These relations suggest that the San Timoteo Anticline may have continued to grow during Qvo time ( $\sim 50$ to $500 \mathrm{ka})$, but terminated during Qo time $(<500 \mathrm{ka})$. Alluvial deposits in the San Timoteo Canyon drainage younger than $100 \mathrm{ka}$ (for example, Kendrick and others, 2002) appear to have accumulated in stable paleogeographic settings, suggesting that fold growth had terminated before that time.

\section{Summary of Fold History}

An inception age of 1.2 Ma for the San Timoteo Anticline is not unreasonable, based on what we know or suspect about the age of the youngest San Timoteo formation and oldest deposits of the Live Oak Canyon sequence. Of interest, this age coincides with when the San Jacinto Fault is thought to have initiated in the Inland Empire region (Matti and Morton, 1993), which may indicate a causal relationship between the two structures. Fanning dips in the Live Oak Canyon succession (steeper dips for older beds, shallower dips for younger beds) suggest that folding continued as the Live Oak Canyon succession accumulated during the interval $\sim 1.2 \mathrm{Ma}$ to $\sim 750 \mathrm{ka}$, and probably as unconsolidated 
surficial deposits of the Qvo and Qo series accumulated during the interval $700 \mathrm{ka}$ to $<500 \mathrm{ka}$. Surficial deposits of the younger Qo and Qy series do not appear to be affected by the anticline.

\section{Relation Between Fold Form and Landscape}

Paradoxically, landscapes associated with the San Timoteo Anticline do not match what might be expected for a youthful anticlinal fold. Intuitively, the highest elevations for an anticlinal landform should coincide with the structural crest of the fold, with the land surface declining in elevation down both limbs. Ideally, this elevation maximum would form a drainage divide separating headward-eroding streams working up both fold limbs toward the fold crest. In the El Casco quadrangle, however, the highest terrain occurs on the anticline's northeast limb as much as $4 \mathrm{~km}$ northeast of the axial crest (fig. 13). This is true even where the Mt. Eden crystalline massif cores the fold: here, the massif and associated sedimentary rocks on the fold crest might be expected to form topographic maxima. This is not the case, however: even here, where the fold crest attains its maximum elevation, the topographic crest of the Badlands lies a few km to the north.

Throughout much of the San Timoteo Badlands the overall landform crest not only lies north of the anticlinal crest, it also forms a relatively flat skyline (fig. 13) that —in the El Casco quadrangletrends west-northwest. Generally, this landscape crest converges northwestward toward the fold's structural crest, but the two do not merge for several kilometers into the Sunnymead quadrangle. This suggests that, in early stages of its structural development, the evolving fold crest in fact may have coincided with a topographic maxima, as it does in the Sunnymead quadrangle. However, as fold growth continued, headward erosion by streams flowing south into the San Jacinto Valley excavated drainages that have expanded northward beyond highground that once may have coincided with the Anticline's axial (see geomorphic surfaces).

\section{Singleton Anticline}

Southeast of Calimesa, in the low foothills between the Banning Fault and the Cherry Valley Fault, the middle member of the San Timoteo formation of Frick (1921) has been warped into an anticlinal fold whose sinuous axial trace plunges as much as 10-13 degrees west. The fold is asymmetric, with a shallowly dipping north limb and steep south limb that is vertical to overturned adjacent to the Cherry Valley Fault. The Singleton Anticline occupies the hanging wall of the Cherry Valley Fault (Rewis and others, 2006, their figs. 5 and 6), and appears to reflect contractional deformation that formed that structure.

\section{Minor Folds}

Minor synclinal and anticlinal folds and warps occur on the shallow north limb of the San Timoteo Anticline. In the central part of the quadrangle between U.S. Highway 60 and Jackrabbit Trail, we map the approximate location and shape of these folds. We attribute this deformation to lowamplitude warping that affected the hanging wall of the Laborde Canyon Fault as the San Timoteo formation detached from the San Timoteo Anticline (discussed below). Similar warps may have affected the San Timoteo formation north of Mt. Eden in the area between Jackrabbit Trail and Laborde Canyon. This rumpled stratigraphy coincides with the highest part of the San Timoteo Badlands (fig. 13, dashed white line), and in part may be responsible for creating topographically elevated landscapes on the north limb of the San Timoteo Anticline that occupy higher elevations than landscapes at the crest of that fold. 


\section{Faults}

\section{Banning Fault}

The Banning Fault is a major right-lateral strike-slip fault that was part of the San Andreas Fault system in late Miocene time (Matti and others, 1992a; Matti and Morton, 1993). In the El Casco quadrangle and to the east in the San Gorgonio Pass region, the fault juxtaposes rocks of San Gabriel Mountains-type on the north against various Tertiary sedimentary deposits on the south (fig. 2). Since late Miocene time the Banning Fault has not been a major tectonic element.

Nomenclature and previous usage-Vaughan (1922) first mapped faults later referred to the Banning Fault; in the east part of San Gorgonio Pass, his map shows these as unnamed faults that extend west from their juncture with the San Andreas Fault. It is clear from Vaughan's text (1922, p. 399-401) that he attached no particular significance to these unnamed faults that he recognized west of the San Andreas; he viewed the latter as the dominant structure. Hill (1928) reinterpreted fault relations in San Gorgonio Pass and introduced the name "Banning Fault" for the fault segments that Vaughan (1922) first identified. Although on his map Hill (1928, plate II) did not specifically designate the Banning Fault, he evidently applied the name to a fault he shows extending from the east part of San Gorgonio Pass west to the San Jacinto Fault and beyond.

Allen (1957) clarified many of the geologic and nomenclatural problems associated with the Banning Fault zone, and his report forms the basis for all later investigations. Allen recognized that the Banning Fault not only is an important zone of crustal convergence, as indicated by thrust and reverse faults associated with the fault in San Gorgonio Pass, but also is an important strike-slip fault having as much as 11 to $19 \mathrm{~km}$ of right-lateral offset. Reexamination of the Banning Fault by Matti and others (1992a; Matti and Morton, 1993) enlarged on Allen's studies by refining the geologic history and tectonic role of the fault zone and proposing $\sim 44 \mathrm{~km}$ of right-lateral offset.

Distribution and geologic setting - Regionally, the Banning Fault can be identified or inferred over a distance of about $100 \mathrm{~km}$ between the Indio Hills and the San Jacinto Fault (fig. 2). The fault zone consists of western, central, and eastern segments, each having a unique geologic and geomorphic setting and each recording a distinctive tectonic and depositional history (Matti and others, 1992a; Matti and Morton, 1993). The fault originally formed a single continuous trace throughout the three geographic segments, but Quaternary structural and depositional events have obscured this continuity.

The El Casco quadrangle lies within the central, or San Gorgonio Pass, segment of the Banning Fault. Within the quadrangle, the fault is exposed intermittently in the foothills that extend eastward from Calimesa. There the fault either is vertical or dips steeply to the north, and forms a distinct plane between a zone of crushed and sheared crystalline rock to the north and deformed sedimentary rock to the south. The crush zone in crystalline rocks locally is as much as $30 \mathrm{~m}$ wide, and forms a prominent white to greenish-white zone best observed at the north end of Singleton Road (for example, Shuler, 1953, fig. 23; Burnham and Dutcher, 1960, p. 99). Westward to Calimesa, the Banning Fault is buried by upper Quaternary deposits, and its position must be inferred. Burnham and Dutcher (1960, fig. 3) report an outcrop of crystalline rock in the SE $1 / 4$ of Section 13, within the Garden Air Golf Course (now the Calimesa Golf Course); we reoccupied this site and observed poorly exposed rock that probably is basement of San Gabriel Mountains-type (shown on the geologic map). These outcrops help constrain the position of the Banning Fault, which must occur south of them. According to Burnham and Dutcher (1960, p. 245-247), the Banning Fault in the El Casco quadrangle may or may not form a barrier to groundwater flow.

Age of faulting - The Banning Fault was an active dextral strike-slip structure during late Miocene time ( $\sim 10 \mathrm{Ma}$ to $\sim 5 \mathrm{Ma})$, when the fault was an eastward continuation of the San Gabriel Fault in the San Gabriel Mountains (Matti and Morton, 1993; our fig. 2). With inception of the San Andreas 
Fault at $\sim 5 \mathrm{Ma}$, dextral slip on the Banning Fault diminished and terminated. However, because it is a significant zone of crustal weakness, the fault has been susceptible to reactivation during subsequent tectonic episodes. This appears to have been the case during Quaternary evolution of the San Gorgonio Pass Fault zone (discussed below). Evidence for this occurs in the northeast corner of the El Casco quadrangle, where the north-dipping Banning Fault juxtaposes crystalline rocks of San Gabriel Mountains-type against folded sedimentary rocks we assign to the middle member of the San Timoteo formation. Here, Woodward-Clyde Consultants (1993, cited by Treiman, 1994, p. 19) observed what they interpreted as Holocene fractures associated with the Banning Fault. In addition, Treiman (1994, Plate IIa) observed what he interpreted as right-deflected stream gullies and other geomorphic features that led California Geological Survey (1995) to zone this part of the Banning Fault as "active", with the potential for surface rupture.

We appreciate the conservative position adopted by California Geological Survey (1995). However, we doubt that fractures and geomorphic features associated with the Banning Fault in the northeast corner of the El Casco quadrangle are the result of throughgoing dextral-slip ruptures on the fault. More likely, these features reflect local movements on the Banning Fault in response to regional strain associated with the San Gorgonio Pass Fault zone. We base this conclusion on our geologic mapping east and west of the area addressed by Woodward-Clyde Consultants (1993) and Treiman (1994): specifically, the Banning Fault in these areas is concealed not only by Holocene alluvial deposits but also by Pleistocene deposits as old as $500 \mathrm{ka}$. Moreover, fault scarps in these alluvial materials in all cases can be associated with strands of the San Gorgonio Pass Fault zone. Thus, we discount the possibility that the Banning Fault during Quaternary time has been the locus of throughgoing dextralslip earthquakes.

\section{San Jacinto Fault}

Nomenclature and previous usage-The San Jacinto Fault is a major element of the San Andreas Fault system in southern California. The name "San Jacinto Fault" first was used by early workers who associated it with earthquakes in 1899 and 1918 that occurred in the vicinity of the San Jacinto Valley and San Jacinto Mountains (Lawson and others, 1908; Rolfe and Strong, 1918; Arnold, 1918; Townley, 1918; Waring, 1919; Hill, 1920, 1928). Later, Noble (1926, 1927, 1932) recognized the fault as a major branch of the San Andreas "rift" in southern California. In the El Casco quadrangle as in the greater San Jacinto Valley region, two strands of the San Jacinto Fault traditionally are recognized: the Claremont Fault and the Casa Loma Fault (Sharp, 1972; Kahle, 1987). The two faults have an en echelon geometry (for example, Morton, 1972, 1977), and many workers propose that a right step from the Casa Loma Fault to the Claremont Fault has led to extensional subsidence of the San Jacinto Valley (Morton, 1977; Matti and others, 1992a, Park and others, 1995). Seismicity associated with the San Jacinto Fault in the San Jacinto Valley region is discussed by Sanders (1993), Sanders and Kanamori (1984), Sanders and Magistrale (1997), and Magistrale and others (2000).

In the El Casco quadrangle we refer to faults of the San Jacinto zone as strands ${ }^{2}$ of the zone, including the Claremont strand, the Casa Loma strand, and the Moreno Valley strand (new).

${ }^{2}$ strand _-"1. one of a number of fibers or threads that are twisted together to form a rope, cord, etc. 5. a thread or thread-like part of anything: the threads of a plot...." (Webster's Encyclopedic Unabridged Dictionary of the English Language, 2001, p. 1879). By analogy, a fault strand is a discrete structure that is associated with other discrete structures within a zone of associated deformation. 


\section{San Jacinto Fault, Moreno Valley Strand}

We apply the new name "San Jacinto Fault, Moreno Valley strand" to a major fault that is best exposed at the west edge of the El Casco quadrangle in the vicinity of U.S. Highway 60. This fault is coextensive with one mapped by Morton (1978c) in the adjacent Sunnymead quadrangle crossing Redlands Boulevard east of the San Jacinto Fault (fig. 1; Morton and Matti, 2001b). There, the fault separates the middle and upper members of the San Timoteo formation (to the east) from sedimentary rocks (to the west) that are quite different. This fault was recognized by English (1953, p. 77, his "Moreno Road fault") and, although he interpreted relations somewhat differently, he recognized that the fault we map at the west edge of the El Casco quadrangle is continuous with the one he mapped in the Sunnymead quadrangle.

Distribution-From the west edge of the El Casco quadrangle, we map the Moreno Valley Fault southeastward across U.S. Highway 60 and thence to the margin of the San Timoteo Badlands. There, the fault could truncate against the Claremont strand of the San Jacinto. Alternatively, we infer that it curves southeastward as a concealed structure that, in the Jackrabbit Trail-Mt. Eden area, connects with faults that we map along the southwest base of the Mt. Eden basement massif (discussed below).

Structural role - We interpret the Moreno Valley Fault as a right-lateral strike-slip strand of the San Jacinto zone, based on how it displaces map units of the San Timoteo formation. Both English (1953) and Morton (1978c) recognized that the fault separates sedimentary materials of the San Timoteo formation that lithologically are quite different. We concur: rocks east of the fault belong to the middle and upper members of the San Timoteo formation, whereas rocks west of the fault belong to a different sequence that we assign to the lower member of the formation (unit Tstls). Thus, the Moreno Valley Fault juxtaposes younger rocks on the east against older rocks to the west. If this stratigraphic interpretation is correct, then the Moreno Valley Fault could be (1) a normal fault having down-to-theeast dip-slip displacement, (2) a reverse fault having up-on-the-west displacement, or (3) a strike-slip fault juxtaposing various members of the San Timoteo formation by right-slip displacement. English (1953) advocated the normal dip-slip interpretation (that is, down to the east). Alternatively, we propose that the Moreno Valley Fault is a strike-slip structure having as much as 8 to $10 \mathrm{~km}$ of right-slip displacement. This interpretation suggests that the fault is a heretofore unrecognized strand of the San Jacinto Fault zone.

Our interpretation is based on the simplest explanation for stratigraphic relations on either side of the fault. Significant down-to-the-east normal-slip on the fault conceivably could account for these relations. However, this scenario seems unlikely for three reasons:

1. The fault plane dips westward (at least in the Sunnymead quadrangle), as indicated by outcrop measurements (English, 1953) and by trench excavations and subsurface borings. Assuming no subsequent rotation of the fault surface, a west dip is not compatible with down-to-the-east normal-slip.

2. A west dip is compatible with a reverse fault having up-on-the-west displacement. However, tectonic geomorphology across the fault zone indicates lower ground to the west, not higher - as would be expected for an up-on-the-west fault. Assuming this geomorphology reflects the entire movement history of the Moreno Valley Fault, and is not just a recent topographic reversal, then the landscape is not compatible with up-on-the-west reverse-slip (or, for that matter, down-tothe-east normal-slip). By contrast, a strike-slip origin for the Moreno Valley Fault would not necessarily lead to predictable patterns of high ground and low ground on either side of the fault.

3. Sedimentary strata within the tectonic slice between the Moreno Valley Fault and the Claremont Fault to the west are deformed into a series of tight folds (Shuler, 1953, p. 56; Michael, 1956; Morton, 1978c); this suggests that the slice has been subjected to contractional deformation. Contraction here is consistent with strain patterns throughout the San Timoteo Badlands region, 
judging from features like (a) the asymmetric San Timoteo Anticline and (b) a left bend in the San Jacinto Fault north of Moreno Valley (Kendrick and others, 2002). A normal-slip origin for the Moreno Valley Fault is not compatible with regional contraction in the Badlands region, although reverse-slip would be-and strike-slip as well, especially if the Moreno Valley Fault was deformed into its current sinuous trace during or after its strike-slip history; discussed below).

Our proposal of as much as $10 \mathrm{~km}$ of right-slip on the Moreno Valley strand is based on reconstructing displaced elements of the San Timoteo formation that occur west of the fault. If our assignment of these strata to the lower member is correct, then lower member beds outboard (west) of the fault need to be restored palinspastically to a prefaulting position compatible with the distribution of San Timoteo map units. The nearest occurrence of the lower member is in the Jackrabbit Trail-Mt. Eden area, some 8 to $10 \mathrm{~km}$ to the southeast. Lower member beds in the western El Casco-Sunnymead area can be reunited with those in the greater Mt. Eden area by restoring 8 to $10 \mathrm{~km}$ of right slip on the Moreno Valley Fault.

This requires that the Moreno Valley Fault continues southeastward and truncates beds of the lower member; the geologic map (sheet 1) adopts this interpretation. Unfortunately, direct evidence for the fault is concealed beneath young alluvial deposits that flank the southwest margin of the San Timoteo Badlands from the west edge of the quadrangle all the way to Mt. Eden. Thus, even though we show a dotted-where-concealed trace of the Moreno Valley strand along this extent, the fault just as easily could be truncated by the younger Claremont strand (as suggested by reviewer W. Reeder). Whether coextensive with the Claremont strand or truncated by it, the essential point is that the Moreno Valley strand has a sinuous trace that probably indicates it was deformed prior to being succeeded by the Claremont strand. Either way, lower San Timoteo member beds (unit Tstls) have been displaced rightlaterally by the Moreno Valley strand from their original position in the Jackrabbit Trail-Mt. Eden region.

This suggests that the strand should be recognizable in the Mt. Eden area as part of the San Jacinto Fault zone. There, in roadcuts of Jackrabbit Trail, a poorly exposed fault significantly disrupts the San Timoteo formation. Northwest of the road in the south half of Section 22, the fault is concealed beneath a large landslide complex; southeast of the road, the fault can be mapped to near the base of the Mt. Eden massif, where it interacts with — or is truncated by - a fault we name the Mt. Eden Fault (fig. 32; discussed below). Although in this area we are not certain of fault assignments and correlations, we propose that the Moreno Valley Fault is truncated by the Mt. Eden Fault, but just southeast continues on via a sinuous structure that traverses sedimentary rocks outboard (west) of the Mt. Eden Fault (sheet 1; magenta line in figs. 32, 33). We considered other fault correlations for this sinuous structure, including that it might be a continuation of a fault that trends southeast from Eden Hot Springs in Sec. 26 (yellow line in figs. 32, 33). However, the latter is a reverse fault (discussed below), whereas the fault along the south margin of Sec. 25 does not have reverse slip: instead, it juxtaposes various members of the San Timoteo formation (to the north) against the arkosic and lithic member of the Mt. Eden formation (to the south) in a manner that reflects either normal-slip or strike-slip. We favor the latter, and thus interpret the sinuous fault along the south margin of Sec. 25 as a continuation of the right-lateral Moreno Valley strand of the San Jacinto Fault. The fault has been interrupted locally by the Mt. Eden Fault (discussed below; sheet 1; figs. 32, 33, 34).

Thus interpreted, the Moreno Valley strand of the San Jacinto Fault extends from the Mt. Eden area northwest into the Sunnymead quadrangle. Between the Mt. Eden area and U.S. Highway 60, the strand's trace largely is concealed beneath landslide deposits and beneath young Quaternary alluvial deposits; hence, the fault's continuity throughout the El Casco quadrangle cannot be proved. However, the sinuous distribution of exposed segments and its relation with map units of the San Timoteo 
formation are compatible with a throughgoing structure. Throughout its observed extent this structure is associated with highly deformed slices of the San Timoteo and Mt. Eden formations.

\section{San Jacinto Fault, Claremont Strand}

The name "Claremont Fault" apparently was introduced by Fraser (1931) in a report describing the geology southeast of the El Casco quadrangle. Frasier's text is ambiguous, because he refers to the Claremont Fault and the nearby Hot Springs Fault as though they are one and the same structure ("...the Hot Springs or Claremont fault lies along the northeastern edge of [the San Jacinto fault zone]"; Frasier, 1931, p. 518). Frasier's geologic map implies that his Claremont Fault continues northwest from its junction with the more easterly Hot Springs Fault. We conclude that Frasier viewed the Claremont Fault as a major strand of the San Jacinto Fault flanking the northeast side of the San Jacinto Valley (also see Sharp, 1972; Sanders and Kanamori, 1984; Park and others, 1995; Lee and others, 1996; Sanders and Magistrale, 1997). We project the Claremont strand along the margin of the San Timoteo Badlands, continuing the fault northwestward from where Frasier (1931) mapped it along the east margin of San Jacinto Valley.

Along this reach, the location of the Claremont Fault is not obvious. Just southeast of the El Casco quadrangle, a conspicuous scarp traversing the Laborde Canyon alluvial fan (figs. 32, 33) presumably represents the Claremont strand (Sharp, 1972; Morton and Matti, 2001a). This scarp can be traced northwest to Bridge Street (Morton and Matti, 2001a), but northwest of this datum it is not obvious that the Claremont strand can be associated with primary fault features - either because they have been obscured by agricultural activities or because they do not exist. Morton and Matti (2001a) queried the fault here, indicating that its existence where shown is not certain.

To the northwest in the El Casco quadrangle, primary features associated with the Claremont strand have not been documented. In this vicinity, some workers have associated the fault with a northwest-trending series of scarps developed along the margin of the San Timoteo Badlands (fig. 32; for example, Shuler, 1953, fig. 21; Sharp, 1972). However, we interpret these topographic features as crown scarps of low-angle slope-movement masses (discussed below, under geomorphic features). Discounting these scarps as tectonic features, we infer the position of the Claremont strand essentially beneath Gilman Hot Springs Road.

Along its northwestern reach in the El Casco quadrangle, the Claremont strand forms scarps that extend intermittently to the western edge of the quadrangle. The scarps are straight to arcuate, face alternately southwest and northeast, and are developed in alluvial deposits we map as unit Qyf $_{3}$ (although we do not have good age control on these deposits); the fault's trace is concealed by alluvium we assign to unit $\mathrm{Qyf}_{5}$. The Claremont strand exits the west edge of the El Casco quadrangle near the intersection of Gilman Hot Springs Road and U.S. Highway 60 (fig. 1).

Southeast of Section 21, the Claremont strand cannot be located confidently because scarps that occur to the northwest do not continue along trend to the southeast. Several features in this vicinity may help clarify what happens to the Claremont strand here:

1. A large Pleistocene landslide complex (unit Qols) in Section 22 bulges the margin of the San Timoteo Badlands southwestward toward the San Jacinto Valley.

2. Coincident with this landslide complex, scarps we associate with the Casa Loma strand of the San Jacinto Fault diagonal across the San Jacinto Valley (discussed below); these become more prominent southeastward in the Lakeview quadrangle (Morton and Matti, 2001a).

3. At the intersection of Jackrabbit Trail and Gilman Hot Springs Road (fig. 1) the largest drainage basin in this part of the San Timoteo Badlands debouches a well-formed Holocene alluvial fan into the San Jacinto Valley; this fan has no fault scarps, and the fan body has not been displaced away from its canyon source. 
Together, these features can be used to infer the distribution of the Claremont strand in the southeastern corner of the El Casco quadrangle.

In this part of the San Jacinto Valley it is likely that the Claremont and Casa Loma strands participate in sequential left and right steps. The left step involves the Claremont strand as it trends northward from the Lakeview quadrangle (Morton and Matti, 2001a) into the map area. Extrapolated northwestward from the scarp that crosses the Laborde Canyon fan in the Lakeview quadrangle, the Claremont strand lies concealed along the edge of the San Timoteo Badlands and almost directly beneath Gilman Hot Springs Road (figs. 32, 33). No primary fault features occur here (contrast with Shuler, 1953, fig. 21; Sharp, 1972), and the inferred trend of the concealed fault points directly at the Pleistocene landslide complex in Sec. 22. This complex does not appear to be displaced or otherwise disturbed by fault traces, and it is old enough that the youthful Claremont strand should cut the mass. Hence, the fault either is concealed beneath the landslide complex, or it steps left in this vicinity. We adopt the left-step hypothesis. Concomitantly, late Holocene displacements on the San Jacinto Fault appear to step right from scarps of the Claremont strand in the northwest corner of the El Casco quadrangle to scarps of the Casa Loma strand where it diagonals across San Jacinto Valley (discussed below). This right step occurs at about the location of the Pleistocene landslide complex in Sec. 22, and is coextensive with the left step in the Claremont strand in the same vicinity. Both left and right steps probably are related responses to the fundamental structure of the San Jacinto Fault zone in this vicinity, and may have yielded a tectonic setting that led to the large landslide complex, the longevity of the unfaulted alluvial-fan cone at the mouth of the large drainage basin in the San Timoteo Badlands, and the subsidence of the San Jacinto Valley to the southeast (Morton, 1977).

\section{San Jacinto Fault, Casa Loma Strand}

According to Treiman (written commun. to J.C. Matti, 4/08/08), the name "Casa Loma Fault" appears to have been introduced by California Department of Water Resources (1959). Frasier (1931) did not use the name, instead referring to this structure as the "San Jacinto Fault". Proctor (1962) is one of the earliest uses of the name. Sharp $(1967,1972)$ referred to the structure as the Casa Loma Fault (also see Morton 1972, 1977; Park and others, 1995; Lee and others, 1996). Most workers view the fault as a component of the San Jacinto Fault zone. Morton and Matti (2001a) emphasized this concept with the name "Casa Loma Fault of the San Jacinto Fault zone", although this usage is awkward etymologically. We herein refine this usage to "San Jacinto Fault, Casa Loma strand", although we use the terms "strand" and "fault" interchangeably.

In the El Casco quadrangle the location of the Casa Loma strand is not established with certainty for two reasons: (1) in valley-floor areas, primary fault features have been obscured by active alluvial and lacustrine sedimentation within the San Jacinto River system; and (2) the land surface has been modified extensively by agricultural activities. For the same reasons, geologic relations in adjacent parts of the Lakeview and Sunnymead quadrangles are not much help in projecting the fault into the El Casco quadrangle. To overcome these difficulties, two seismic-imaging investigations recently were conducted: one in the Lakeview quadrangle (Lee and others, 1996) and the other in the El Casco quadrangle (Park and others, 1995). These investigations shed light on some fault relations, but add uncertainty to others.

In the Lakeview quadrangle, seismic-refraction and -reflection studies by Lee and others (1996) imaged several fault strands. One of these (offset II of Lee and others, 1996, figs. 1 and 4, p. 1263) has acoustic characteristics compatible with significant down-to-the-east displacements expected if the Casa Loma Fault is the western boundary of the extensional San Jacinto Valley graben. Oddly, the location of this acoustic fault does not coincide with the surface trace of the Casa Loma Fault mapped on the basis of east-facing topographic scarps (Sharp, 1972; Morton, 1977, fig. 3; Morton and Matti, 2001a). Scarps attributed to the Casa Loma Fault that cross seismic Line P9 of Lee and others (1996) coincide with 
another acoustic fault (offset III of Lee and others, 1996, figs. 1 and 4), but it has displacements opposite from those indicated by the topographic scarps. These geologic and seismic-imaging incompatibilities bear on the location of the Casa Loma Fault farther northwest in the El Casco quadrangle.

In the map area, seismic-reflection studies by Park and others (1995) imaged several fault strands. Their Line SJ3 along the unnamed east-trending road about $1.6 \mathrm{~km}$ south of Allesandro Boulevard imaged two fault zones that bear on discussion of the Casa Loma Fault: (1) a fault zone near the middle of Line SJ3 (Park and others, 1995, p. 694-695, fig. 4, Station 230) and (2) a fault zone near the west end of Line SJ3 (Park and others, 1995, fig. 4, their "flower structure" between stations 124 and 170). Park and others (1995, p. 694) refer to the former as the "Farm Road strand" and the latter as the projected trace of the Casa Loma Fault (see text and additional figures in Park and others, 1995, for how the seismic interpretations in Line SJ3 are compared and correlated with data from their other seismic lines). Park and others (1995, fig. 3) cite Rogers (1965) for the surface location of the Casa Loma Fault.

The "Farm Road strand" of Park and others (1995) is an interesting feature that may be relevant to surface features we map farther south in Section 28 of the El Casco quadrangle. There, we recognize a north-northwest-trending series of subtle, east-facing topographic scarps in the vicinity of ground fissures documented by Morton (1977, fig. 4, especially fig. 4C). This feature may just be another in a series of cracks and fissures associated with ground subsidence in this part of the San Jacinto Valley (Morton, 1977). However, its spatial continuity and the slight elevation differences across it (down-tothe-east) suggest that its origin is unrelated to the subsidence-related features described by Morton (1977).

We tentatively attribute the topographic scarps in Section 28 to a strand of the San Jacinto Fault zone (also see Sharp, 1972). Specifically, we propose that they represent a continuation of the Casa Loma strand northward from the Lakeview quadrangle into the El Casco quadrangle. The scarps have a more central position within the San Jacinto Valley than do scarps attributed to the Casa Loma strand farther south (Sharp, 1972; Morton, 1977; Morton and Matti, 2001a), which suggests that the Casa Loma strand in the El Casco quadrangle is stepping right (east) from a more westerly position farther south in the San Jacinto Valley. Of interest, the Section 28 scarps point toward the projected trace of the acoustic "Farm Road strand" of Park and others (1995), although we cannot connect the two geologic features and the acoustic fault has no surface expression observed by us. We tentatively conclude that, in the El Casco quadrangle, most recent activity on the Casa Loma strand of the San Jacinto Fault steps right onto the Claremont strand. The scarps in Section 28 record this stepover.

Unresolved by our work is the relation between the Section 28 scarps, which we interpret as tectonic, and the seismic-imaging results reported by Lee and others (1996) in the Lakeview quadrangle to the south. The scarps in Section 28 point southward toward queried fault traces recognized by Morton and Matti (2001a), but not toward offset II of Lee and others (1996, figs. 1 and 4, p. 1263). Further work is required to resolve these discrepancies.

\section{Geologic Summary, San Jacinto Fault Zone}

Displacement - The San Jacinto Fault is a major component of the San Andreas Fault system in southern California. Its multiple strands have generated on the order of 20-26 km of right-lateral displacement since its inception (Sharp, 1967; Matti and Morton, 1975, 1993; Morton and Matti, 1993; Dorsey, 2002). In the El Casco quadrangle, sedimentary materials of the San Timoteo and Mt. Eden formations provide clues into the amount of right slip within the San Jacinto zone.

In his study of the San Timoteo Badlands, English (1953) discussed two geologic occurrences in and near the El Casco quadrangle that he cited as evidence for about $18 \mathrm{~km}$ of right slip within the San Jacinto Fault zone: 
1. English (1953, p. 81-84, fig. 27) suggested that greenish-gray fine-grained sedimentary materials in roadcuts of U.S. Highway 60 at its intersection with Gilman Hot Springs Road (fig. 1) are lithologically and stratigraphically similar to outcrops on the opposite side of the San Jacinto Fault in the Reche Canyon area of the San Bernardino South 7.5' quadrangle, about $11 \mathrm{mi}$ (18 $\mathrm{km}$ ) northwest of the El Casco quadrangle (Morton, 1978a, unit "Ts"). English proposed that the two outcrop sequences have been displaced by right-slip on the San Jacinto Fault. Burnham and Dutcher (1960, p. 63) also recognized the potential importance of the distinctive Reche Canyon beds, and concluded that "possibly they were brought into their present position relative to the rest of the unit [San Timoteo formation] by large-scale movements on the San Jacinto Fault". Burnham and Dutcher (1960) do not point to a specific area on the opposite side of the San Jacinto Fault from which the Reche Canyon beds might have been displaced.

2. English proposed that quartz diorite boulders associated with the Mt. Eden formation near Jackrabbit Trail (English, 1953, p. 40-41) may have been sourced from similar basement rocks of Peninsular Ranges-type that crop out on the opposite side of the San Jacinto Fault near Reche Canyon (English, 1953, p. 84-85, fig. 27).

Our mapping suggests other interpretations that can explain the observations by English (1953). Matti and Morton (1975) independently recognized the significance of the Reche Canyon sedimentary rocks, but concluded that they compare not to fine-grained mudrock near the intersection of Gilman Hot Springs Road and State Highway 60 (compares to English, 1953) but to rocks in the Mt. Eden area that we assign to the fine-grained and ripple-laminated units of the San Timoteo formation (units Tstlr and Tstlf). We restate this cross-fault correlation here, and emphasize that it calls for $\sim 25 \mathrm{~km}$ of cumulative right-slip on all strands of the San Jacinto Fault.

As additional evidence for displacement on the Claremont Fault, English (1953, p. 40-41) cited boulders associated with his "lower member of the Mt. Eden formation" (our arkosic member of the Mt. Eden formation, unit Tmea). The significance of these boulders is open to interpretation.

Unquestionably, the boulders are exotic to the Jackrabbit Trail-Mt. Eden area; they also are quite different from tonalite boulders in the Laborde Canyon area that occur as conglomerate (our unit Tmeb) interbedded with the Mt. Eden formation. The latter are identical with the tonalite of Lamb Canyon (unit $\mathrm{Ktl}$ ), and undoubtedly were sourced from outcrops of that unit during the late Miocene depositional history of the Mt. Eden formation (discussed above). The boulders near Jackrabbit Trail are quite different: they consist of foliated, coarse-grained hornblende-biotite tonalite to quartz diorite unlike any basement units exposed in the southeastern San Timoteo Badlands area. We are not convinced, however, that the boulders actually are interbedded with the Mt. Eden formation, as interpreted by English (1953): the boulders typically occur at various levels on hillslopes underlain by the Mt. Eden formation, and we did not observe any actually incorporated within these beds. It appears to us that most, if not all, of the boulders have been let down to their current positions during erosion of the Badlands landscape.

Whether interbedded within the Mt. Eden sequence or let down onto the sequence by erosion, the quartz-diorite boulders are exotic to the Jackrabbit Trail area and, as suggested by English (1953), must be derived from a source now removed from the area by right-slip displacements within the San Jacinto Fault zone. Like English, we believe the boulders are similar to bedrock south of the Reche Canyon area of the Sunnymead quadrangle (Morton and Matti, 2001b, unit "Kt"). We suspect that the boulders bounced and tumbled down a bedrock hillside and landed in the vicinity of Jackrabbit Trail when it was positioned adjacent to the Reche Canyon bedrock massif. However, rather than invoking this event in late Miocene time ( $>5$ million years ago) while the Mt. Eden formation was accumulating, we propose that the boulders bounced downslope during Quaternary time as the Reche Canyon terrane was sliding northwestward past the Jackrabbit Trail area from an original position farther southeast. By this scenario, the boulders landed not on a late Miocene landscape on which the Mt. Eden formation was 
accumulating but rather on a Quaternary landscape developing on the San Timoteo and Mt. Eden formations. Continued erosional modification of that landscape has let the boulders down to their current positions as observed by English (1953, p. 40-41). This accounts for why the boulders appear to be resting on the land surface rather than interbedded within the Mt. Eden formation.

Displacement age-The exact age for inception of the San Jacinto Fault long has been debated. Traditional interpretations call for fault inception at about $2.5 \mathrm{Ma}$, based on considerations of long-term slip rates and total fault displacement. Many kinematic models for the San Jacinto Fault (for example, Weldon and Sieh, 1985; Weldon and Humphreys, 1986 Humphreys and Hager, 1990; Humphreys and Weldon, 1994) assume a long-term slip rate of about $10 \mathrm{~mm} /$ year based on geologic studies by Sharp (1981) and based on geodetic-strain determinations for the San Andreas Fault in the Salton Trough region. Using widely cited estimates of about $25 \mathrm{~km}$ for total right-slip on the San Jacinto zone and assuming a steady long-term rate of $10 \mathrm{~mm} /$ year, faulting traditionally is inferred to have initiated about 2.5 m.y. ago. Thus, a long-lived San Jacinto Fault traditionally is viewed as a branch of the San Andreas system that has shared $10 \mathrm{~mm} / \mathrm{yr}$ of the total plate rate in southern California for the last $2.5 \mathrm{~m} . \mathrm{y}$.

Alternatively, Matti and others (1985, 1992a; Matti and Morton, 1993; Morton and Matti, 1993) argued for inception of right-slip on the San Jacinto zone no earlier than 1.2 to $1.5 \mathrm{~m}$.y. ago, based on (1) the history of the San Andreas Fault in the San Gorgonio Pass region and (2) the depositional history of Pliocene through middle Pleistocene sediments in the San Timoteo Badlands (Morton and others, 1986; Morton and Matti, 1993). We adopt this hypothesis here. Although not yet confirmed, a younger inception for the San Jacinto Fault (and faster long-term slip rate) is suggested by two independent lines of evidence:

1. The San Jacinto Fault in the Moreno Valley area is accumulating about $25 \mathrm{~mm} /$ year of rightlateral shear strain, assuming the fault is locked to depths of $20 \mathrm{~km}$ (Savage and Prescott, 1976).

2. Morphometric and kinematic analyses by Kendrick and others (2002) of the San Jacinto Fault in the vicinity of its left bend southeast of the San Bernardino South quadrangle suggests minimum long-term Quaternary strike-slip rate on the San Jacinto of 20+ mm/yr.

If correct, elevated long-term rates of $20-25 \mathrm{~mm} / \mathrm{yr}$ in the vicinity of the El Casco quadrangle are twice the long-term rate of about $10 \mathrm{~mm} / \mathrm{yr}$ usually attributed to the fault. This requires that inception of right-slip on the zone may have begun no earlier than about 1.2-1.5 Ma, instead of about 2.5 Ma.

Strand sequencing and cumulative history - In the El Casco quadrangle, the San Jacinto Fault zone consists of at least three strands that have contributed to cumulative right-slip displacement within the zone. These strands have the following geometric and kinematic relations:

1. The Moreno Valley strand is the oldest strand, judging from its sinuous trace. We interpret this sinuosity to be the result of contraction that occurred when the Moreno Valley strand was deformed and abandoned by the San Jacinto Fault zone, at which time the younger Claremont and Casa Loma strands were initiated. The Moreno Valley strand has $\sim 8-10 \mathrm{~km}$ of right-slip, depending on the exact match-up between outcrops in the Sunnymead quadrangle and cross-fault counterparts in the Mt. Eden area.

2. Relations between the Casa Loma and Claremont strands suggest that, throughout much of the San Jacinto Valley, the Casa Loma has had the most recent displacements and is younger. This is based on the conspicuous scarp developed along that strand in the southern part of the Valley and the absence of primary tectonic geomorphology for much of the Claremont strand.

3. In the El Casco quadrangle, slip on the San Jacinto zone appears to step right (east) from the Casa Loma strand to the Claremont strand, which then continues northwest and forms conspicuous (but discontinuous) scarps in young Holocene alluvial deposits. 
4. The Casa Loma and Claremont strands together have about $15-17 \mathrm{~km}$ of combined right slip, based on total displacement of $\sim 25 \mathrm{~km}$ for the entire San Jacinto zone and $\sim 8-10 \mathrm{~km}$ on the Moreno Valley strand.

5. All three strands of the San Jacinto Fault merge northwest of the El Casco quadrangle in the Sunnymead quadrangle (Morton and Miller, 2006).

\section{Faults Associated with the Mt. Eden Massif}

The crystalline Mt. Eden massif is associated with a series of faults that have up-on-the-northeast displacements (figs. 32, 33, 34, 35) and appear to have contributed to the massif's uplift. The faults have been recognized by previous workers (English, 1953; Shuler, 1953; Beyer, 1959; MacLeod, 1961), but poor exposures and ambiguous geologic relations have led to various structural interpretations. We apply the names "Eden Hot Springs Fault" and "Mt. Eden Fault" to these structures (sheet 1), and we discuss them as separate entities. However, the faults appear to be related geometrically and kinematically, and we discuss their structural roles in a single concluding section.

\section{Eden Hot Springs Fault Zone}

The Eden Hot Springs Fault is a zone of northwest-trending faults best observed in the Eden Hot Springs area at the northwest end of the Mt. Eden massif (figs. 32, 33, 34, 35). Previous studies and our own mapping lead to the following observations:

1. Faults of the Eden Hot Springs complex juxtapose crystalline rocks of the Mt. Eden massif against the Mt. Eden formation, especially along the massif's southwest margin.

2. Some of the faults can be mapped eastward into the crystalline massif, but largely are concealed there by heavy brush.

3. The faults appear to be northeast-dipping high-angle reverse faults.

4. In general, poor exposures make it difficult to map the faults through the Mt. Eden formation; however, in the vicinity of Eden Hot Springs we map one strand of the fault zone through the formation for a short distance northwestward away from the crystalline massif (sheet 1, lightgreen fault in fig. 33).

5. Faults of the Eden Hot Springs complex do not obviously break units of the San Timoteo formation.

6. Faults of the zone are associated with water wells having elevated water temperature (Waring, 1919, p. 11).

Age of faulting - We suspect that the Eden Hot Springs Fault zone is Quaternary in age, although this interpretation is speculative. Clearly, faulting postdates deposition of the late Miocene Mt. Eden formation and - because the faults do not obviously break the overlying San Timoteo formation-could have occurred in latest Miocene time before the latter was deposited. Such an event would have created structural and topographic relief in the Mt. Eden area, which in turn could have led (1) to unconformable relations between the two formations (see English, 1953) and (2) to the presence of the heterogeneous member of the Mt. Eden formation (unit Tmeh) in the Mt. Eden area but its absence in Laborde Canyon to the east. However, we did not observe evidence for either possibility: (1) Although English (1953, p. 55) interpreted stratal convergence north of Eden Hot Springs as evidence for an unconformity, like Shuler (1953, his figs. 11-12) we interpret angular stratal convergence here to faulting; (2) we attribute the spatial distribution of unit Tmeh as the result of facies changes rather than depositional variability on an unconformable landscape. Finally, we doubt that the Eden Hot Springs Fault zone is as old as late Miocene because not only is there no compelling evidence for this age in the map area but no other 
instance of reverse or thrust faulting of late Miocene age has been documented in the Inland Empire region.

We use relations between faults of the Eden Hot Springs zone and beds of the San Timoteo formation in the hanging wall of the Laborde Canyon Fault as evidence for a Quaternary age for the Eden Hot Springs zone. As noted above, we have not observed faults of the Eden Hot Springs zone to cut the San Timoteo formation, a relation that could be interpreted to mean that faulting occurred prior to deposition of San Timoteo beds. However, we note that faults of the Eden Hot Springs zone also do not appear to cut the Laborde Canyon Fault. As discussed below, the latter is a moderately north-dipping normal fault that extends from Laborde Canyon on the southeast to Jackrabbit Trail on the northwest, and places San Timoteo formation in its hanging wall against Mt. Eden formation in its footwall. We propose that faults of the Eden Hot Springs zone are younger than the San Timoteo formation but older than the Laborde Canyon Fault: the Eden Hot Springs structures would have been observed to cut the San Timoteo beds was this structural relation not concealed by down-to-the-north displacements on the Laborde Canyon Fault that emplaced a hanging wall block of San Timoteo formation over a footwall block that includes San Timoteo beds faulted by the Eden Hot Springs complex. This relation is represented in figures 33 and 35 by dotted green lines (concealed faults) extending from the Mt. Eden massif beneath the Laborde Canyon hanging wall. By this interpretation, reverse faults of the Eden Hot Springs complex are probably middle Quaternary in age - that is, younger than the San Timoteo formation (younger than $\sim 1.4 \mathrm{Ma}$; discussed above) and older than youngest movements on the Laborde Canyon normal fault (probably $\sim 1.2 \mathrm{Ma}$, discussed below).

\section{Mt. Eden Fault}

Distribution - We apply the name "Mt. Eden Fault" to a moderately north- and northeast-dipping fault that has elevated the Mt. Eden massif and strongly deformed adjacent rocks of the Mt. Eden and San Timoteo formations (figs. 32, 33, 34). At the southeast margin of the quadrangle (fig. 34), the Mt. Eden Fault dips from $40^{\circ}$ to $60^{\circ} \mathrm{N}$. and juxtaposes crystalline rocks of Mt. Eden against vertical to overturned strata of the Mt. Eden formation (sheet 1; note the fault-dip arrows in fig. 34). Traced northwestward, the fault converges toward the Moreno Valley strand of the San Jacinto Fault (figs. 32, 33). Where the two faults intersect in the NE $1 / 4$ Sec. 26 (T. 3 S., R. 2 W.) exposures are poor and geologic relations are ambiguous, but the Mt. Eden Fault appears to truncate and overlap the Moreno Valley strand (but see English, 1953, Beyer, 1959, and MacLeod, 1961 for alternative structural interpretations here). Northwest of this complicated intersection an east-dipping reverse fault can be mapped toward the Eden Hot Springs area (figs. 32, 33); the fault juxtaposes older parts of the Mt. Eden formation in the hanging wall against younger Mt. Eden beds in the footwall, and reverse displacements have produced an up-on-the-east scarp (fig. 32). The fault along this reach has the same reverse-slip sense as that along the southwestern base of the Mt. Eden massif, hence we correlate the two structures and assign them both to the Mt. Eden Fault.

Northwest of Eden Hot Springs, all workers project what we call the Mt. Eden Fault northwestward beneath alluvial deposits in the unnamed canyon directly east of Jackrabbit Trail (center of Sec. 23, T. 3 S., R. 2 W.; figs. 32, 35; English, 1953; Beyer, 1959; MacLeod, 1961). Beyond here there is no clear solution for what happens to the fault, mainly because exposures are poor and because the San Timoteo sedimentary sequence to the northwest lacks distinctive marker beds that facilitate recognition of fault offsets. We extend the Mt. Eden Fault at least as far north as the center of Sec. 23 (English, 1953, concurs, but for different reasons) because there the fault displaces the Laborde Canyon Fault and associated hanging wall and footwall stratigraphy. The displacement sense is similar to that for the Mt. Eden Fault to the southeast (reverse-slip, east side up), and appears to be about the same amount as where it displaces the Mt. Eden formation southwest of Eden Hot Springs. We have not traced the Mt. Eden Fault farther to the northwest; it could splay into a distributive zone of faults observable in 
roadcuts of Jackrabbit Trail (sheet 1) or it could project beneath the Laborde Canyon Fault — or both. The latter case would apply only to older displacements on the Mt. Eden Fault, because its most recent displacements clearly break the Laborde Canyon structure.

Interpretation - We are not completely satisfied with our mapping and interpretation of the Mt. Eden Fault and related structures. For example: At the southeast edge of the El Casco quadrangle the fault hugs the base of the Mt. Eden massif, and clearly has a reverse component of slip that has juxtaposed basement rocks of the massif against (and locally over) steeply dipping to overturned rocks of the Mt. Eden formation (figs. 32, 33, 34; sheet 1). Here, reverse displacement has been great enough to separate Mt. Eden beds at the base of the massif from offset counterparts several hundred meters higher atop the massif (fig. 33). Traced to the northwest, the Mt. Eden Fault diverges away from the crystalline massif and trends more northerly across a lowland underlain by the Mt. Eden formation and capped by alluviated erosional surfaces (fig. 32, fig. 33, red-dot pattern). Puzzling aspects of this distribution pattern include:

1. As it trends toward Eden Hot Springs, the Mt. Eden Fault not only diverges from the Mt. Eden massif but it also appears to have considerably less vertical separation: (a) to the southeast, the contrast between high-standing massif and low-standing Mt. Eden beds is dramatic; (b) to the northwest, this dramatic relief is replaced by a low scarp that represents no more than a few tens of $\mathrm{m}$ of vertical displacement (fig 32).

2. Despite this apparent slip discrepancy, in the vicinity of the scarp the Mt. Eden formation is separated from counterparts atop the Mt. Eden massif to approximately the same degree as further to the southeast, where this relation can be attributed convincingly to faulting along the base of the Mt. Eden massif (figs. 32 and 33).

3. Moreover, in the lowland traversed by the fault scarp, the axial trace of the San Timoteo Anticline (red lines in fig. 33) that warps beds of the Mt. Eden formation is disconnected from its continuation atop the massif, where the fold recurs in the Mt. Eden formation. Clearly, the anticlinal fold and the Eden beds have been broken and displaced by uplift of the massif (figs. $32,33,34)$ - uplift that we cannot explain solely by the documented distribution of reverse-slip faults (Eden Hot Springs and Mt. Eden faults) along the massif's southern and western margins).

Structural interpretation of the Mt. Eden Fault may be even more complex if it played not only a reverse-slip role in uplifting the Mt. Eden massif but also a right-slip role as part of the San Jacinto Fault zone - at least along the southwestern base of the Mt. Eden massif (indicated by strike-slip arrows in figs. 32, 33, 34). This is suggested by relations just southeast of the El Casco quadrangle, where the Mt. Eden Fault occupies a linear valley between the Mt. Eden massif (to the north) and a slice of complexly deformed Mt. Eden and San Timoteo formations (to the south) (figs. 32, 33, 34). Shuler (1953, fig. 20) suggested that this linear valley is occupied by a strike-slip fault (he thought it was the Claremont Fault); Morton and Matti (2001a) also mapped a fault here, but they did not name it or indicate its slip style. Note: In the El Casco quadrangle any fault that occupies this valley occurs at the base of the Mt. Eden massif (figs. 33, 34) whereas, to the southeast, this fault diverges from the massif and forms a conspicuous northern boundary for the slice of complexly deformed Mt. Eden and San Timoteo formations. This slice is transected by linear stream valleys (fig. 34, red and light-blue dashed lines) that to the north are beheaded by the Mt. Eden Fault. The beheaded stream valleys strongly indicate dextral slip on the Mt. Eden Fault, with the valleys displaced dextrally from incised streams heading into the Mt. Eden massif. Thus, the Mt. Eden Fault appears to have both a right-slip component and a reverseslip component, with the latter most obvious in the El Casco quadrangle (sheet 1).

Age of faulting - We suspect that the Mt. Eden Fault is Quaternary in age, although this interpretation is speculative. Clearly, faulting postdates deposition of the upper Miocene Mt. Eden formation. Moreover, the Mt. Eden Fault clearly disrupts not only beds of the San Timoteo formation 
but also the Laborde Canyon Fault (the latter relation can be observed northwest of Eden Hot Springs). Truncation of the Laborde Canyon Fault indicates that at least youngest displacements on the Mt. Eden Fault postdate down-to-the-north normal slip on the former-an event that we interpret to be no older than mid-Quaternary in age (discussed below). Thus, we suspect that - like the Eden Hot Springs Fault — the Mt. Eden Fault generated reverse-slip during the middle and late Quaternary $(<1.5 \mathrm{Ma})$. Geologic summary - We have not definitively worked out the distribution, sequencing, geometry, and kinematics of the Mt. Eden Fault. For sure, the fault along the base of the Mt. Eden massif has produced up-on-the-northeast reverse slip, and this structural style appears to represent the fault's most recent tectonic role. However, the sedimentary slice (Mt. Eden and San Timoteo formations) between the Mt. Eden massif and the San Jacinto Valley displays geomorphic features indicative of right-slip on this reach of the Mt. Eden Fault. Our mapping supports the following interpretations:

1. The Mt. Eden Fault clearly is identifiable along the southwestern base of the Mt. Eden massif, where there is good evidence for both reverse-slip and right-slip.

2. A fault that traverses the low surface along the western base of the massif (figs. 32, 33, yellow line) appears to be a continuation of the Mt. Eden Fault because, like it, the fault has reverse slip and can be mapped southeastward into the reverse fault along the massif's steep south margin. The lowland fault forms a scarp in the arkosic and lithic member of the Mt. Eden formation (unit Tmea), but the modest amount of reverse separation required to form the scarp does not compare with that required to separate occurrences of the Mt. Eden formation atop the Mt. Eden massif and along its western and southwestern base (figs. 33, 34).

3. The lowland scarp can be traced north-northwest to the Eden Hot Springs area, and beyond there the fault displaces the low-angle Laborde Canyon Fault by an amount compatible with slip required to form the scarp. These relations indicate that the Mt. Eden Fault west of the Mt. Eden massif is young enough to have produced a recognizable scarp landform and to have displaced the Laborde Canyon Fault and the axial surface of the San Timoteo Anticline-structures that both evolved during and after inception of the San Jacinto Fault zone at about 1.2-1.5 Ma.

4. The discrepancy between large reverse-slip on the Mt. Eden Fault along the south margin of the Mt. Eden massif and smaller slip on the scarp traversing the lowland west of the massif continues to trouble us. Without doubt, the Mt. Eden formation atop the massif has been displaced from stratigraphic counterparts along both the south and west margins of the massif, and the prominent fault we map as the Mt. Eden Fault along the south margin clearly is responsible for this structural and topographic relief. Given that reverse-slip on the lowland fault scarp alone could not have generated similar relief along the massif's west margin, we suspect that undocumented up-to-the-northeast reverse faults along this margin have contributed to the massif's uplift and thereby account for anomalous structural, stratigraphic, and geomorphic relations here. We associate these speculative structures (green dashed and queried lines in figs. 32, 33, and 34) with both the Mt. Eden and Eden Hot Springs faults.

5. We conclude that reverse-slip offset on the Mt. Eden Fault-in conjunction with simultaneous reverse-slip offset on the Eden Hot Springs Fault and speculative extensions of the two faultsled to uplift of the Mt. Eden massif in relation to flanking units of the Mt. Eden and San Timoteo formations. The scarp-forming segment of the Mt. Eden Fault (yellow line in figs. 32, 33) is the youngest player in this structural sequence. Given that the Mt. Eden massif cores the San Timoteo Anticline, it seems reasonable that the Mt. Eden and Eden Hot Springs reverse faults not only are responsible for massif uplift but also are a symptom of the same contractional events that led to the fold's development. 
6. In our discussion of the Laborde Canyon Fault zone we reason that it is a down-to-the-north normal fault that developed on the north limb of the San Timoteo Anticline as the fold grew. Our proposal that the Eden Hot Springs Fault projects beneath the Laborde Canyon Fault and is associated with reverse-slip uplift of the Mt. Eden massif suggests that strands of the Eden Hot Springs Fault may have been involved in uplifting the massif in the core of the San Timoteo Anticline (fig. 33). The three structural features-Eden Hot Springs Fault, Laborde Canyon Fault, San Timoteo Anticline - thus appear to be related kinematically and chronologically, a relation that would allow the Eden Hot Springs Fault to be younger than the San Timoteo formation but older than the Laborde Canyon Fault. This would allow down-to-the-north displacement on the latter to conceal evidence for the Eden Hot Springs Fault, except where the latter is exposed in the footwall of the former, as on the Mt. Eden massif.

7. This leaves unresolved what happens to right-slip observed on the Mt. Eden Fault farther to the southeast along the margin of the Mt. Eden massif (figs. 32, 33, 34). We suspect, but have not documented, that right-slip on the Mt. Eden Fault feeds northwest onto the Moreno Valley strand of the San Jacinto Fault between Mt. Eden and Jackrabbit Trail, thereby reactivating that structure and leaving behind the sinuous trace of the Moreno Valley strand that we map west of the Mt. Eden Fault (figs. 32, 33, 34).

Thus, the Mt. Eden Fault in the vicinity of Mt. Eden has a complex and hybrid geologic history. Clearly, reverse slip on the fault played a role in uplifting Mt. Eden basement rocks. Prior to or synchronous with that reverse history, the Mt. Eden Fault also had a right-slip history that postdates right-slip on the Moreno Valley strand of the San Jacinto Fault and disrupted its sinuous trace. In addition, the scarp-forming segment of the Mt. Eden Fault that trends toward Eden Hot Springs displaces the Laborde Canyon Fault, which in turn displaces the axial surface of the fold (discussed below). Thus, latest displacements on the Mt. Eden Fault postdate normal slip on the Laborde Canyon Fault zone, and both faults are related to growth of the fold and uplift of the Mt. Eden massif. This suggests that reverse-slip (and right-slip?) on the Mt. Eden Fault was coeval with several events: (1) uplift of the Mt. Eden massif, (2) growth of the San Timoteo Anticline, and (3) normal-slip on the Laborde Canyon Fault zone - all of these being coeval with inception and development of the San Jacinto Fault zone 1.2 to 1.5 million years ago. The Mt. Eden Fault thus is Quaternary in age, and appears to have contributed to landscape evolution in this part of the San Timoteo Badlands.

\section{Laborde Canyon Fault Zone}

We apply the name "Laborde Canyon Fault zone" to a belt of sinuous north-dipping normal faults developed in the vicinity of the Mt. Eden basement massif (figs. 35, 36, 37).

Distribution - We map the faults from the Laborde Canyon area west to the Jackrabbit Trail area. At the southeast edge of the El Casco quadrangle, the Laborde Canyon Fault zone forms a single strand that juxtaposes the arkosic member of the Mt. Eden formation (unit Tmea) against the boulderconglomerate member (unit Tmeb). Morton and Matti (2001a) project this fault (unnamed) southeast into Section 32 (T. 3 S., R. 1 W.) of the Lakeview quadrangle, although they were not able to extend the structure farther. The fault zone in fact can be mapped into lower Lamb Canyon where its structures curve east and east-northeast and continue to displace the boulder-conglomerate member (unit Tmeb; J.C. Matti, unpub. mapping, 1973-1974). Shuler (1953, p. 61-62) also mapped northeast-trending faults in lower Lamb Canyon that he interpreted as "horsts" uplifting bedrock that we map as boulder conglomerate; Shuler speculated that these structures are related to the Lawrence Fault in the San Gorgonio Pass region, as mapped by Hill (1928) and by Henderson (1939). We did not see any reference to this idea in Henderson (1939). 
We map a single Laborde Canyon Fault northwestward across Laborde Canyon, where the fault splays into several structures that curve west and then northwest toward the Mt. Eden basement inselberg (fig. 13). Along this reach, faults of the Laborde Canyon zone dip moderately northward and juxtapose various Tertiary sedimentary units, including several members of the San Timoteo formation (units Tstlf, Tstlr, and Tstls) dropped down to the north against the arkosic member of the Mt. Eden formation (unit Tmea). The downfaulted beds are warped into a west-plunging anticline that is repeated in various fault slices; these appear to be segments of the San Timoteo Anticline that have been displaced down and northeast from the main fold crest that occurs just to the south in upthrown rocks of the Laborde Canyon footwall. If correct, the displaced fragments of the axial surface constrain dip-slip displacement on the Laborde Canyon Fault zone in this vicinity to less than a few hundred meters.

West toward Mt. Eden, multiple strands of the Laborde Canyon Fault zone converge into a single fault that passes sinuously through a conspicuous saddle northeast of Mt. Eden (figs. 36, 37) and continues west toward the Eden Hot Springs area. Along this reach the Laborde Canyon Fault dips $\sim 50^{\circ}$ northward and juxtaposes the lower member of the San Timoteo formation (unit Tstls) against the Mt. Eden formation (unit Tmeh); San Timoteo units such as the ripple-laminated and fine-grained units (units Tstlr and Tstlf) are cut out along the base of the fault. This tectonic relation was recognized earlier by Shuler (1953), Beyer (1959, p. 19-20), and MacLeod (1960). Along this reach, angular stratal relations across the fault zone suggest an angular unconformity (Shuler, 1953, p. 33, figs. 11, 12; MacLeod, 1961, p. 13-14); in fact, English (1953, p. 55) proposed an unconformity along this boundary, although he cited thickness variations among various map units rather than angular stratal relations. We agree with Shuler $(1953$, figs. 11, 12) that in this vicinity drag and deformation associated with our Laborde Canyon Fault are responsible for converging strata along the boundary between the Mt. Eden and San Timoteo formations.

Between Eden Hot Springs and Jackrabbit Trail, the Laborde Canyon Fault is a low- to moderate-angle structure that "v's" northward into the three canyons in the NE1/4 Sec. 23 (T. 3 S., R. 2 W.) northwest of Eden Hot Springs (fig. 35). Along this reach the lower member of the San Timoteo formation (unit Tstls) forms the hanging wall while, beneath the fault, uppermost strata in the footwall generally consist of the heterogeneous member of the Mt. Eden formation (unit Tmeh). As these relations are traced westward, however, the fine-grained and ripple-laminated units of the San Timoteo formation (units Tstlf and Tstlr) appear in the footwall as progressively younger beds emerge beneath the hanging wall (sheet 1); in fact, isolated slices of the ripple-laminated unit not mappable at 1:24,000 scale occur farther to the east in the Eden Hot Springs area. Westward toward Jackrabbit Trail relations are partially obscured by poor exposures, but the Laborde Canyon Fault appears to slice obliquely even higher into the San Timoteo formation, with the result that the fault here separates the lower member (unit Tstls) in the hanging wall from the ripple-laminated unit (Tstlr) and fine-grained unit (Tstlf) in the footwall. These two units thicken westward to their full measure at Jackrabbit Trail.

This interpretation explains a major anomaly in the structure and stratigraphy of the greater Mt. Eden-Laborde Canyon area: the Laborde Canyon stratal succession seems to be structurally too low relative to where it should be on the north limb of the northwest-plunging San Timoteo Anticline (sheet 1). This anomaly becomes apparent when the Laborde Canyon succession is compared with the Jackrabbit Trail succession, also on the north limb of the fold. Despite stratigraphic differences, both successions span the boundary between the San Timoteo and Mt. Eden formations, and both contain the ripple-laminated and fine-grained units of the San Timoteo formation. But given the northwest plunge of the San Timoteo Anticline, the Jackrabbit Trail sequence should have wrapped into the Laborde Canyon area at a position farther north than its actual position near the south margin of the El Casco quadrangle.

Displacement on the Laborde Canyon Fault zone explains this anomalous geometry. Down-tothe-north slip on normal faults of the zone has dropped the Laborde Canyon stratal succession to a position on the north limb of the San Timoteo Anticline that is structurally lower than it should be, thus 
effectively placing the Laborde Canyon succession in the "wrong" place relative to the Jackrabbit Trail succession. This geometry is possible because the Laborde Canyon Fault west of Mt. Eden (sec 23, T. 3 S., R. 2 W.) slices diagonally through the boundary zone between the Mt. Eden and San Timoteo formations: as a result, the Jackrabbit Trail succession west of the center of Section 23 is in the footwall of the Laborde Canyon Fault, whereas the Laborde Canyon succession is in the hanging wall. This allows the boundary zone between the Mt. Eden and San Timoteo formations to be structurally lower than it should be in the Laborde Canyon area.

At the major canyon directly west of Jackrabbit Trail, we face alternative possibilities for the Laborde Canyon Fault:

1. A singular fault surface does not continue much farther west, and normal-slip displacement on the Laborde Canyon Fault to the east is dispersed as distributed strain among unmapped fractures, minor faults, and subtle warps that characterize the lower member of the San Timoteo formation throughout much of the central part of the quadrangle.

2. One or more discrete mappable faults trend northwest up canyons that head northnorthwestward into the center of the San Timoteo Badlands. These faults would be concealed beneath alluvial fill of the canyons, and like option (1) would serve to dissipate normal-slip on the main Laborde Canyon Fault zone farther east.

3. The fault wraps westward and southward around the plunging nose of the San Timoteo Anticline and occupies the south limb of the fold, continuing to separate the lower member of the formation (unit Tstls) in the hanging wall from the ripple-laminated unit (Tstlr) and the fine-grained unit (Tstlf) in the footwall.

Our mapping suggests that option (3) is the best solution. This is depicted on the geologic map (sheet 1).

Structural role-The Laborde Canyon Fault appears to be kinematically related to development of the San Timoteo Anticline. We base this interpretation on spatial and geometric relations between the two structures. To begin with, the Laborde Canyon Fault footwall consists mainly of the Mt. Eden formation and underlying basement rocks of Mt. Eden itself; in general, the hanging wall consists of the San Timoteo formation (fig. 35). Next, in the Eden Hot Springs/Jackrabbit Trail area, the axis of the San Timoteo Anticline lies southwest of the Laborde Canyon Fault, and affects strata in the fault's footwall. Note, however, that in the Laborde Canyon area, the axial surface of the anticline locally has been truncated by strands of the Laborde Canyon Fault and displaced northeast in the fault's hanging wall. These relations suggest that, as the San Timoteo Anticline grew and as the Laborde footwall rose within its axial zone, part of the cover sequence detached from the uplifting mass along the Laborde Canyon Fault zone. Mudrock of the fine-grained and ripple-laminated units of the San Timoteo formation may have formed a weak zone where detachment could localize, given that the Laborde Canyon Fault generally occurs in that stratigraphic interval. This is seen best north and northeast of Eden Hot Springs on the northeast slope of the Mt. Eden massif.

Left unanswered by this detachment model is what happens to the Laborde Canyon Fault west of Jackrabbit Trail. Options (1) and (2) above are compatible with a detachment model, and would require that faulting everywhere occurred on the northeast limb of the evolving San Timoteo Anticline. Option (3) could support this model, but raises the possibility that the fault wrapping around the nose of the San Timoteo Anticline is an early strand of the normal-slip Laborde Canyon detachment zone that was abandoned and subsequently folded as the anticline continued to grow; to the north, detachment along the Laborde Canyon zone would have continued on the north limb as the fold continued to grow (options 1 and 2). This would require that displacements within the Laborde Canyon Fault zone occurred episodically. 
A much different kinematic interpretation would apply if the Laborde Canyon Fault wraps around the nose of the plunging anticline (option 3, above) but - instead of being an abandoned and folded normal-slip fault - it represents a reverse-slip fault that interacted kinematically with normal-slip on the Jackrabbit Trail-Laborde Canyon section of the Laborde Canyon structure. This would require faulting simultaneously on both limbs of the evolving San Timoteo Anticline: down-to-the-north normal slip on the fold's north limb accompanied concurrently by reverse-slip on the fold's south limb. As discussed above, the San Timoteo Anticline is strongly asymmetric, having a shallow northeast limb and a steep southwest limb. In the vicinity of the Mt. Eden massif the steep limb locally is overturned to the southwest, and interacts with and is truncated locally by the Mt. Eden reverse fault that has uplifted the massif along its southwest margin. These geometric relations would require that, as the Laborde Canyon Fault wraps around the northwest-plunging nose of the San Timoteo Anticline, normal slip typical of the fault transforms into reverse-slip along the steep southwestern limb of the Anticline.

This raises a further possibility that a reverse-slip segment of the Laborde Canyon Fault might transition southeastward into the Mt. Eden reverse fault along the southwest side of the Mt. Eden massif, with both faults playing a contractional role in response to regional development of the San Timoteo Anticline. This could explain puzzling spatial patterns in slip distribution for the Mt. Eden Fault: as discussed above, that structure appears to have large reverse-slip displacement along the southwest margin of the Mt. Eden massif, but considerably less slip where we map the fault southeast of Eden Hot Springs. These slip discrepancies could be accounted for if reverse-slip on the Mt. Eden Fault feeds west-northwest onto the Laborde Canyon Fault on the south limb of the San Timoteo Anticline.

Whatever its geometry and kinematics, the Laborde Canyon Fault zone apparently is an accommodation structure that developed as the basement core of the San Timoteo Anticline rose and the fold formed.

\section{San Gorgonio Pass Fault Zone, Cherry Valley Strand}

First named by Smith (1979), the San Gorgonio Pass Fault zone was mapped westward by Matti and others $(1985,1992 \mathrm{a})$ who recognized it as a series of Quaternary reverse, thrust, and tear faults that extends from the Whitewater area westward to the Calimesa area (fig. 2). This system is associated spatially with the Banning Fault, but the kinematic evolution of the San Gorgonio Pass Fault zone has no temporal relation to that structure.

Regionally (fig. 2) the San Gorgonio Pass Fault zone has a distinctive zigzag character caused by repetition of a distinctive fault geometry - an L-shaped pattern in which the elongate staff of the " $L$ " is oriented northwestward and the shorter base of the "L" eastward to northeastward. The east-oriented segments are thrust and reverse faults, whereas the northwest-oriented segments appear to be high-angle tear faults having oblique right-lateral displacement. These northwest-oriented segments have approximately the same orientation as right-lateral fault strands of the San Andreas system.

Distribution - In the El Casco quadrangle, the San Gorgonio Pass Fault zone is represented by the Cherry Valley Fault of Bloyd (1971, pl. 1); faults associated with the trace first appear to have been recognized by Shuler (1953) (J. Treiman, written commun. to Matti, 4/8/08). Traced from the east edge of the quadrangle, the Cherry Valley Fault separates gently sloping alluvial deposits of the Beaumont Plain from low foothills to the north. Along this reach the fault is a north-dipping thrust that carries folded strata of the middle member of the San Timoteo formation in the hanging wall south over younger sedimentary materials of the footwall. The fault breaks alluvium we map as unit Qof , but upper Pleistocene and Holocene units appear to be unbroken; the fault zone is poorly exposed along this reach, however, and upper Pleistocene deposits could be faulted. Trench exposures at one location along this stretch show the fault dipping north about $15^{\circ}$ (CHJ Consultants, 2004). 
Traced westward across Interstate Highway 10, the Cherry Valley Fault forms a scarp in the sedimentary deposits of Live Oak Canyon (figs. 38-41; Matti and others, 1985, 1992a). Where trenched by consultants (CHJ Consultants, 1986, cited by Rasmussen and Associates, 1988a,b; Petra Consultants, 2004) the Cherry Valley Fault dips north between $11^{\circ}$ and $45^{\circ}$ (figs. 38, 39, 40, 41). Several features characterize the fault in these trench exposures:

1. Although depicted as a single feature on the geologic map, the fault actually forms a narrow zone having two or more individual fault surfaces associated with the scarp that marks the zone (fig. 38).

2. Hanging-wall strata of the Live Oak Canyon unit are warped into one or more southwestplunging anticlinal folds like the Singleton Anticline (sheet 1); the south limbs of these folds dip moderately to steeply, and locally are vertical to overturned (figs. 39, 40, 41). These features are consistent with drag along the fault plane and south vergence of the fault zone as a whole.

3. In some trench excavations, the hanging wall has overridden colluvial detritus that appears to be derived from the fault scarp. Some of these colluvial wedges appear to have only weak pedogenic-soil development, leading to considerable discussion among trench observers as to whether faulting was recent enough to have carried the hanging wall over Holocene deposits (unlikely).

4. In many trench exposures, the hanging wall can be seen to project southward atop an old landscape surface developed on both older alluvial deposits and the sedimentary deposits of Live Oak Canyon, depending on location; in such instances, the fault surface is nearly flat, leading to the inference that, as the hanging wall moved up the north-dipping fault zone, it moved out over existing landscape surfaces and acquired whatever dip the surfaces had. This observation, together with well preserved scarp-derived colluvium, testifies not only to the youthful age of faulting associated with Quaternary landscapes but to deeper rooted earthquake ruptures that were able to propagate to the land surface and form clearly recognizable tectonic geomorphology.

The scarp associated with the Cherry Valley Fault can be mapped westward to about the boundary between Sections 15 and 16 (T. 2 S., R. 2 W.). There, the scarp morphology diminishes, and we have not been able to recognize the fault in poor exposures at the northwest edge of the El Casco quadrangle. We suspect that the Cherry Valley Fault does not extend beyond the quadrangle.

Structural role-Throughout the San Gorgonio Pass region, the San Gorgonio Pass Fault zone represents a zone of crustal convergence associated with complexities in the San Andreas Fault zone (fig. 2). In the El Casco quadrangle, the Cherry Valley Fault appears to be the westernmost part of this convergence zone. The age and duration of faulting are not completely documented, but contraction probably developed early in the Pleistocene and influenced the evolution of landscapes and depositional sequences for much of Quaternary time. Faults with confirmed Holocene displacements have been identified only in the eastern part of the San Gorgonio Pass zone between Beaumont and Whitewater (Matti and others, 1985, 1992a; fig. 2), but Holocene deposits in the greater Beaumont Plain areaincluding the El Casco quadrangle - appear to be unfaulted (but see preceding discussion of fault-scarp colluvium in trench exposures). In the El Casco quadrangle, the Cherry Valley strand of the zone breaks upper Pleistocene alluvial deposits we assign to unit Qof 2 . If the Cherry Valley Fault actually terminates in the El Casco quadrangle, as we suspect, then contraction associated with the San Gorgonio Pass zone may extend no farther west than the Calimesa region, which suggests that the west end of the Cherry Valley Fault may be a pivot point east of which the hanging wall of the San Gorgonio Pass Fault zone rotated clockwise and southward over the footwall. If correct, then convergence across the San Gorgonio 
Pass zone increases eastward, with progressively more footwall thrust beneath the hanging wall in the San Gorgonio Pass region (low-density material modeled by Langenheim and others, 2005).

We have not determined whether the Cherry Valley Fault in the El Casco quadrangle (a) steepens northward and roots into the Banning Fault, or (b) retains its shallow north dip for a considerable distance beyond the Banning Fault and therefore truncates that structure (see Rewis and others, 2006). The latter geometry raises the possibility that the June 16, $2005 \mathrm{M}_{\mathrm{L}} 4.9$ Yucaipa earthquake (Carena and Yue, 2005) was associated with the down-dip continuation of the Cherry Valley Fault.

\section{Beaumont Plain Fault Zone}

Matti and others $(1985,1992 \mathrm{a})$ applied the name "Beaumont Plain Fault Zone" to a series of northwest-trending en echelon faults that break upper Pleistocene alluvium underlying the gentle terrace surface beneath Beaumont. Although topographic maps of the area do not apply a name to this geomorphic surface, other workers (Young and others, 1941) have referred to it informally as the "Beaumont Plain" - a name that Matti and others (1985) applied to the fault complex. Faults of the Beaumont Plain zone trend more northerly than right-lateral strike-slip faults of the San Andreas family.

In the El Casco quadrangle, faults of the Beaumont Plain zone occur along the east-central margin of the quadrangle and trend north-northwest toward the Cherry Valley Fault. Two of the faults form west-facing scarps in alluvium we assign to units Qvof $_{3}$ and Qof ${ }_{1}$; to the northeast, a third fault strand forms an east-facing scarp in alluvial unit Qof 2 (Treiman [1994] maps a fourth scarp that we overlooked). In the El Casco quadrangle none of these faults appears to break Holocene deposits, although evidence for Holocene fault ruptures in the zone has been documented to the east in the Beaumont quadrangle (Rasmussen and Associates, 1988a,b; CHJ Consultants, 2004). The northwestward extent of the faults is not known, but they appear to die out south of the Cherry Valley Fault. To the southeast, faults of the Beaumont Plain zone probably enter the San Timoteo Badlands, and we associate an east-facing scarp in the SE $1 / 4$ Section 8 (T. 3 S., R. 1 W.) with the zone. However, careful geologic mapping and photo interpretation would be required to document the association between faulting in the Badlands and that in the Beaumont Plain Fault zone.

Structural role-Matti and others $(1985,1992$ a) interpreted the Beaumont Plain Fault zone as a late Quaternary belt of normal dip-slip faults possibly having an oblique right-slip component. The faults are oriented subparallel with the San Andreas Fault (San Bernardino strand), although they have a more northerly trend. They actually have trends similar to those of northwest-oriented right-lateral tear faults of the San Gorgonio Pass Fault zone (see fig. 2). That said, we do not have a kinematic model for how faults of the Beaumont Plain complex fit into a regional strain paradigm.

\section{San Timoteo Fault}

We herein apply the name "San Timoteo Fault" to a concealed structure whose location we infer in the subsurface north of San Timoteo Canyon; on the geologic map (sheet 1) the fault is tagged with question marks to indicate that its existence (not its identity) is questionable. Based on indirect evidence, we project the fault from the east margin of the El Casco quadrangle northwest to the Calimesa area. There, the structure may continue northwest beneath the hanging wall of the Cherry Valley Fault. We terminate the San Timoteo Fault at the concealed trace of the Banning Fault, but we have no information about geometric and kinematic relations between the two structures. Southeast of the El Casco quadrangle, the fault probably enters the San Timoteo Badlands where it appears to splay into multiple structures that break the San Timoteo sedimentary sequence (J.C. Matti and others, unpub. geologic mapping). We interpret the San Timoteo Fault as a northeast-dipping down-to-the-east normal fault. 
In the El Casco quadrangle, evidence for the existence and location of the San Timoteo Fault is indirect:

1. Hydrologic investigations by the U.S. Geological Survey (Bloyd, 1971; Rewis and others, 2006) indicate that groundwater in the Beaumont-Cherry Valley storage area (as used by Bloyd, 1971) flows southwest toward the center of the El Casco quadrangle; there, it rises to the surface in the large unnamed canyon downstream from the intersection of Singleton Road and Interstate Highway 10 (fig. 1). There, marshy ground and artesian springs reported by Bloyd (1971; also see Mendenhall, 1905) indicate a groundwater barrier that requires a geologic explanation. A fault in this vicinity would provide such a barrier, and although no fault has been identified or mapped there on the basis of surface exposures, the inferred San Timoteo Fault may play a role in ponding groundwater.

2. North of San Timoteo Canyon, low hills southwest of the inferred trace of the San Timoteo Fault are capped by a reddish residual soil (unit Qvors); this pedogenic soil marks an old Quaternary landscape surface developed on top of the sedimentary deposits of Live Oak Canyon (unit Qlo). The residual soil can be recognized from the central northeast part of the El Casco quadrangle northwest to the Calimesa area, but nowhere east of this line of hills (Sec. 36, north of the junction of San Timoteo Creek and Little San Gorgonio Creek in Sec. 1, T. 3 S., R. 2 W.). There, the topography is abruptly lower, and younger alluvial deposits buttress depositionally against the highground of units Qlo and Qvors. This relation can be explained by a northwest-trending concealed fault that drops the Live Oak Canyon unit (Qlo) and its capping residual soil (Qvors) into the subsurface northeast of the fault.

Our recognition of the San Timoteo Fault is based on these hydrologic and geomorphic relations. The fault is entirely concealed by younger Quaternary alluvial deposits on the order of a few hundred thousand years old, but is young enough to have displaced deposits of unit Qlo (here probably about 700,000 years old) and the paleosol of unit Qvors (here on the order of 500,000 years old). This inferred structure accounts for stratigraphic and landscape features in the area, and also provides a barrier to groundwater flow in the canyon southwest of Singleton Road.

The structural role and age of the San Timoteo Fault are not clear. Down-to-the-east displacements suggest a normal dip-slip origin, provided the fault is east dipping (which it likely is). The San Timoteo Fault thus is similar to strands of the Beaumont Plain Fault Zone. However, it has a more westerly orientation than those structures and clearly is older than late Quaternary in age. Its lower age limit is not known, but we suspect that the San Timoteo Fault originated after the paleolandscape and residual soil (unit Qvors) began to develop on top of the sedimentary deposits of Live Oak Canyonthat is, less than $500 \mathrm{ka}$. The fault thus probably is an early component of the Beaumont Plain Fault zone.

Reviewer Treiman (written commun. to Matti, 4/8/2008) questioned whether the San Timoteo Fault zone continues as far to the southeast as we show it on the geologic map (sheet 1), or whether in the El Casco quadrangle it is coextensive with other faults of the Beaumont Plain complex. We respond to this legitimate question by noting that numerous northwest-trending down-to-the-northeast faults occur in the northern San Timoteo Badlands southeast of our inferred trace of the San Timoteo Fault. These faults may be random instances that have no relation to other faults. However, we suspect that they are part of the Beaumont Plain complex, and thus we associate them with the San Timoteo Fault.

\section{Geomorphic Features}

A variety of geomorphic features occur in the El Casco quadrangle, some related to ground deformation and others related to landscape evolution. 


\section{Ground Fissures}

On the level valley floor of the San Jacinto Valley in the southwest part of the El Casco quadrangle, an extensive set of ground fissures deforms fine-grained sediment of lacustrine unit Qvylm. These were investigated by Morton (1977), who concluded that they were related to sediment compaction and subsidence within the San Jacinto graben. Various kinds of surface deformation in the San Jacinto graben have been investigated by Fett and others (1967) and Lofgren (1976).

\section{Slope-Movement Scarps}

A series of irregularly curving to broadly arcuate topographic scarps occurs in the southwest part of the El Casco quadrangle, along and adjacent to Gilman Hot Springs Road (fig. 32). Many of these are parallel to inferred traces of the San Jacinto Fault zone, and conceivably could be scarps related to faulting (see Sharp, 1972, map strip C, his "SW-facing eroded scarp associated with the adjacent concealed fault trace"). However, we interpret these features to be crown scarps and subsidiary scarps of blocks that are sliding valleyward above low-angle subsurface slide planes. Many of the scarps are associated with open ground fissures and cracks that appear to be tensional in geometry and origin. All of this evidence suggests that the scarps are not tectonic, but rather are the result of shallow-angle slopemovement processes.

We do not map slope-movement deposits associated with the scarps, for two reasons: mainly because downslope from the scarps we cannot identify boundaries (toes and margins) for discrete slide masses, but also because the alluvial-fan stratigraphy and geomorphology of the affected deposits is not disrupted significantly by the slope-movement processes, either because translational and rotational displacements of the slide masses have not been significant, or because the sliding process is so slow and incremental that dislocations and deformations other than the scarps themselves are difficult to identify.

\section{Geomorphic Surfaces}

Geomorphic surfaces (erosional and aggradational) are developed here-and-there throughout the El Casco quadrangle. Some of these have limited areal extent, and reflect local conditions only. Others are spatially more extensive, and record landscape response to geomorphic and structural events that affected the entire San Timoteo Badlands.

\section{Mt. Eden Surface}

We apply the name "Mt. Eden surface" to an erosional landscape developed atop gently dipping sedimentary rocks of the San Timoteo formation north of Mt. Eden. English (1953, p. 85-89, figs. 28, 29) originally applied the name "San Timoteo surface" to this landform, but we use the name "Mt. Eden surface" in order to differentiate it from landforms farther north in the vicinity of San Timoteo Canyon. Once widespread, the Mt. Eden surface now is represented mainly by two large remnants: one directly north of Mt. Eden (figs. 13, 35), the other in the vicinity of Mt. Davis (fig. 35). English proposed that his "San Timoteo surface" north of Mt. Eden correlates with a relatively level surface capping the summit of the massif itself (figs. 13, 35); the two surfaces have been separated by about 45 to $61 \mathrm{~m}$ (150 to 200 $\mathrm{ft}$ ) as the result of faulting (English, 1953, p. 86). This separation is about the same as that we infer (based on geologic evidence) for down-to-the-north displacement on the Laborde Canyon Fault zone, suggesting that this fault is responsible for disrupting the Mt. Eden surface (fig. 13).

Table 3 summarizes possible scenarios for the origin and age of the Mt. Eden surface. Among these, it is most likely that the surface formed after folding associated with the San Timoteo Anticline had terminated (Table 3, Option 3). Only then would landscapes in the Mt. Eden area have been stable 
enough for beveling processes to sculpt a surface on top of tilted San Timoteo beds. We associate initiation of the San Timoteo Anticline with initiation of right-slip on the San Jacinto Fault zone - an event that probably occurred between about 1.2 and 1.5 Ma (discussed above; Matti and Morton, 1993; Morton and Matti, 1993). Thus, we envision a series of sequential events that include initiation of the San Jacinto Fault, warping of the San Timoteo Anticline, development of the Mt. Eden surface, and subsequent down-to-the-north displacement by the Laborde Canyon Fault zone-all occurring since $\sim 1.2 \mathrm{Ma}$.

Table 3. Possible scenarios for evolution of Mt. Eden surface in El Casco quadrangle.

\begin{tabular}{|c|c|c|c|}
\hline & Surface-forming period & Rationale & Supporting or contradictory evidence \\
\hline Option 1 & $\begin{array}{l}\text { Surface forms prior to } \\
\text { inception of the San Timoteo } \\
\text { Anticline and San Jacinto } \\
\text { Fault-in other words, prior } \\
\text { to fault inception at } \sim 1.2 \text { to } \\
1.5 \mathrm{Ma}\end{array}$ & $\begin{array}{l}\text { Prior to faulting, landscape } \\
\text { would have been stable } \\
\text { enough to promote surface } \\
\text { erosion }\end{array}$ & $\begin{array}{l}\text { Contradictory: Inclined strata of San } \\
\text { Timoteo formation on north limb are } \\
\text { beveled by erosional surface, hence } \\
\text { the surface did not form until after } \\
\text { the San Timoteo beds had been tilted }\end{array}$ \\
\hline Option 2 & $\begin{array}{l}\text { Surface forms intermittently } \\
\text { throughout the genesis of the } \\
\text { San Timoteo Anticline, } \\
\text { during periods of low } \\
\text { tectonic rates (assumes } \\
\text { secular variations in regional } \\
\text { strain budget within the San } \\
\text { Andreas Fault system in the } \\
\text { Inland Empire region; for } \\
\text { example, Bennett and others, } \\
\text { 2004) }\end{array}$ & $\begin{array}{l}\text { Right-slip on the San } \\
\text { Jacinto Fault and attendant } \\
\text { growth of the San Timoteo } \\
\text { Anticline might have been } \\
\text { episodic over last } 1.2 \text { to } 1.5 \\
\text { Ma, thus episodes of } \\
\text { surface development could } \\
\text { occur in the San Timoteo } \\
\text { Badlands region during } \\
\text { periods of low strain }\end{array}$ & $\begin{array}{l}\text { Contradictory: No evidence that } \\
\text { surfaces developed at different times } \\
\text { in different places throughout San } \\
\text { Timoteo Badlands, and no variation } \\
\text { of dips in San Timoteo beds beneath } \\
\text { the Mt. Eden surface; surfaces are } \\
\text { not tilted northward, as they would } \\
\text { have to be if they formed before or } \\
\text { during folding }\end{array}$ \\
\hline Option 3 & $\begin{array}{l}\text { Surface forms after growth } \\
\text { of San Timoteo Anticline } \\
\text { ceases }\end{array}$ & $\begin{array}{l}\text { After folding and uplift } \\
\text { terminated, landscape } \\
\text { would have been stable } \\
\text { enough to promote beveling } \\
\text { and surface development }\end{array}$ & $\begin{array}{l}\text { Supportive: (1) Inclined strata of San } \\
\text { Timoteo formation on north limb are } \\
\text { beveled by erosional surface, hence } \\
\text { surface developed after tilting had } \\
\text { occurred }\end{array}$ \\
\hline
\end{tabular}

A puzzling question lies in the attitude of the Mt. Eden surface vis-à-vis (a) the San Timoteo Anticline and (b) other landscape elements in the vicinity of the San Timoteo Badlands:

- First, the Mt. Eden surface slopes gently toward the anticlinal crest (fig. 13), rather than away from it. This is counterintuitive: whether the surface is coeval with fold development or postdates it, we would have expected the surface to slope gently away from any crestal highground. Instead, the Mt. Eden surface climbs gently toward the northeast.

- Second, a drainage divide (fig. 13, white dashed line) separates the Mt. Eden surface from San Timoteo Canyon landscapes just to the north, suggesting that there is no connection between them. It is not obvious how this highground developed, or what its role is with regard to the origin of the Mt. Eden surface.

- Third, the Mt. Eden surface predates canyons and arroyos incised by streams that head into the Badlands from the San Jacinto Valley and that are aggressively eroding sedimentary rocks that underlie the Badlands. These streams themselves raise questions, 
as their drainage basins have expanded northeastward beyond the anticlinal fold crest and are cannibalizing the fold's north limb. To do so, they first had to breach any highground associated with the anticline crest.

All of this landscape evolution postdates the Mt. Eden surface and thus places an upper limit on its age.

These events need to be integrated with proposals by Morton and others (1990) and Kendrick (1999; Kendrick and others, 2002) that the San Timoteo Anticline and its associated landscapes record a time-transgressive response to structural and geomorphic events accompanying the evolution of the San Jacinto Fault. These workers suggest that the San Timoteo Anticline evolved as sedimentary materials in the San Timoteo Badlands slipped past a restraining bend in the San Jacinto Fault located northwest of the El Casco quadrangle in the vicinity of Reche Canyon (fig. 1). The fold thus is time-transgressive: it is older to the southeast and younger to the northwest, close to the restraining bend. Simultaneously, high-standing basement terrains on the southwest side of the San Jacinto Fault were displaced northwestward away from the Badlands, leaving in their wake its unshielded southwest flank of soft sedimentary rocks that then could be attacked by streams flowing into the subsiding San Jacinto Valley (Kendrick, 1999). The modern landscape reflects this history: drainages along the southwest margin of the Badlands increase in size southeastward toward Mt. Eden and beyond (Morton and others, 1990; Kendrick, 1999; Kendrick and others, 2002). This spatial pattern presumably reflects the longer time that drainages in the southeastern Badlands had to evolve and enlarge compared to those to the northwest that have evolved more recently. When and how the Mt. Eden surface developed in the context of this time-transgressive landscape evolution needs to be evaluated.

If Option 3 in table 3 is correct, then the age of the Mt. Eden surface is constrained to after growth of the San Timoteo Anticline ceased, but before the surface began to be cannibalized by headward-eroding streams flowing toward the San Jacinto Valley. Timing for these events depends on (1) the amount of right slip required on the San Jacinto Fault to get basement rocks out of the way and to expose the soft southwestern margin of the Badlands, (2) the rate at which the basement rocks were displaced (probably $>20 \mathrm{~mm} / \mathrm{yr}$ ), and (3) erosion rates for streams eroding headward into sedimentary rocks like those of the San Timoteo succession. Development of the Mt. Eden surface would fit somewhere into this structural and geomorphic scenario, and probably occupied only a brief segment of the last 1.2 Ma—-probably not more than a few hundred thousand years.

\section{Relations Between Mt. Eden Surface and Other Landscapes}

Left unaddressed by the preceding discussion is the age of the Mt. Eden surface relative to (a) inception of San Timoteo Canyon (fig. 1), (b) origin of the Badlands skyline profile (fig. 13, dashed white line), and (c) evolution of landscape surfaces (Calimesa surface) that cap the sedimentary deposits of Live Oak Canyon (unit Qlo). Origin of the Mt. Eden surface needs to be compatible with how and when these landforms evolved.

Key geologic and geomorphic events include:

1. Inception of the San Timoteo Anticline and associated landscapes ( 1.2 Ma).

2. Initial deposition of unit Qlo in a synformal trough northeast of the San Timoteo Anticline $(\sim 1.1 \mathrm{Ma})$.

3. Cessation of unit Qlo deposition (post-Bruhnes-Matuyama reversal, 700 ka?).

4. Stabilization of a landscape surface on top of unit Qlo, accompanied by development of a residual soil (unit Qvors). Unit Qvors probably is correlative with the oldest of three pedons described by Kendrick (1996, 1999, her unit Q3; Kendrick and others, 1994, 2002), which suggests that when unit Qlo ceased accumulating, its depositional upper surface was 
continuous between the mouth of San Timoteo Canyon and the east boundary of the El Casco $7.5^{\prime}$ quadrangle.

5. Incision of ancestral San Timoteo Creek tributaries into units Qlo and Qvors ( $\sim 700$ ka to $\sim 650 \mathrm{ka}$ ).

6. Accumulation of units $\mathrm{Qvof}_{3}$ and $\mathrm{Qof}_{2}$ in ancestral San Timoteo Creek paleovalleys, with

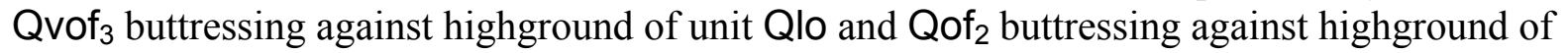
both units Qlo and Qvof 3 ( $\sim 600 \mathrm{ka}$ to $\sim 100 \mathrm{ka})$.

All this landscape evolution occurred in the north part of the El Casco quadrangle - that is, north of the skyline profile indicated by the white dashed line in Figure 13. Meanwhile, the Mt. Eden surface was developing south of this profile. We suspect it formed during episodes (4) and (5), especially as San Timoteo Creek was incising its modern drainage net. This seems to be born out by vestiges of the Mt. Eden surface in the headwaters of Laborde Canyon (discussed in the next section): there, remnant surfaces perched well above the modern valley floors pass transitionally northward across the Badlands skyline (dashed white line in fig. 13) to merge with surfaces that are part of the San Timoteo Canyon drainage net. This is one of only a few places where landscapes south and north of the skyline drainage divide can be observed to meet, again suggesting temporal linkage between the Mt. Eden surface and the San Timoteo Canyon paleodrainage.

Finally, the relatively flat Badlands skyline itself needs to be explained in the context of events (1)-(6) above. Clearly, the skyline highground does not coincide with the axial crest of the San Timoteo Anticline; rather, it occurs on the fold's gently inclined north limb (see Relation between fold form and landscape). We build on the work of Morton and others (1990) and Kendrick (1999; Kendrick and others, 2002) by proposing that headward growth and enlargement of drainages flowing into San Jacinto Valley along the southwest margin of the Badlands not only has breached the San Timoteo Anticline but has reached a common point on the north limb of the San Timoteo Anticline - a point whose elevation is approximately the same in each drainage. This common elevation coincides with the anomalously flat skyline profile of the San Timoteo Badlands (fig. 13). Thus, the intersection between structural processes and geomorphic processes yields the current landscape of the San Timoteo Badlands as displayed in the El Casco 7.5' quadrangle.

\section{Canyon-Margin Surfaces}

Here and there throughout the El Casco quadrangle, canyons are bordered by surfaces perched between canyon bottom and ridge crest (sheet 1). These are especially prominent along tributaries of upper Laborde Canyon, but also are conspicuous along headward parts of tributaries draining north into San Timoteo Canyon; the latter are beheaded southward by streams flowing into San Jacinto Valley. The canyon-margin surfaces probably are remnant floors of former stream valleys that have been incised by late Quaternary erosion. Many of these occur at elevations comparable to the Mt. Eden surface north of Mt. Eden, suggesting that they are part of the same landscape system. This landscape had a NWtrending drainage divide separating south-flowing streams graded to San Jacinto Valley and northwardflowing streams graded to San Timoteo Canyon; this divide is preserved in the headwaters of Laborde Canyon, but no longer is present farther to the northwest where it has been cannibalized by headwarderoding streams draining into San Jacinto Valley. This landscape pattern needs to be factored into scenarios for drainage-basin evolution proposed by Morton and others (1990) and by Kendrick (1999).

\section{Eden Hot Springs Surfaces}

A localized set of geomorphic surfaces occurs on the south and southwest side of the Mt. Eden massif (fig. 32). These are aggradational surfaces developed atop upper Quaternary alluvial sediments of 
unit Qofu (fig. 33, red-dot pattern), but that unit accumulated on an underlying degradational landscape developed atop unit Tmeh. It is not clear how this erosion surface relates to the Mt. Eden surface to the north, but if it is the same age then its lower elevation relative to the Mt. Eden surface may constrain the amount and timing of reverse-slip on the Mt. Eden and Eden Hot Springs Faults and normal-slip on the Laborde Canyon Fault.

\section{Calimesa Surface}

Calimesa surface - North of San Timoteo Canyon, an erosional surface is developed atop gently dipping beds of the sedimentary deposits of Live Oak Canyon (unit Qlo); we apply the name "Calimesa surface" to this landform. Although once extensive north of the San Timoteo Badlands, the surface has been reduced spatially owing to (1) north-heading incision by tributaries of San Timoteo Creek and (2) southward depositional onlap by middle and upper Pleistocene surficial deposits (units Qvof and $_{3}$ of $_{2}$ ). For these reasons, in the El Casco quadrangle the Calimesa surface is represented mainly by reddened and rounded remnants locally capping ridge crests (fig. 11). Traced northward into the Yucaipa quadrangle the ridgecrest remnants coalesce to form a surface that is more extensive. The surface commonly is marked by a reddened carapace laced with white to light-gray calcic stringers, lenses, and fracture fillings, and locally is littered with pebbles and cobbles of white aplite derived from underlying unit Qlo (fig. 11). We interpret this carapace as a weathering profile and pedogenic soil developed atop the Calimesa surface; where scale permits, we map this material as unit Qvors (sheet 1). The surface appears to correlate with surface Q3 of Kendrick (1999; Kendrick and others, 2002), which probably is older than $500 \mathrm{ka}$.

\section{Cherry Valley Surface}

In the east-central part of the El Casco quadrangle, an aggradational surface caps widespread deposits of unit Qof 2 ; we apply the name "Cherry Valley surface" to this aggradational landform. This surface is part of a gently inclined lowland between Beaumont and Banning to which Young and others (1941) applied the name "Beaumont Plain". This footprint includes landforms not associated with the aggradational surface capping unit Qof $_{2}$, so to avoid confusion we refer to the latter as the "Cherry Valley surface". The surface is deeply incised by tributaries of San Timoteo Creek but — counter intuitively_northern parts of the surface are being overlapped by southward-prograding alluvial deposits of the Qvy, Qy, and uppermost Qo series. Thus, the Cherry Valley surface is being cannibalized from the south while simultaneously being buried by sediment derived from the north. The El Casco quadrangle affords glimpses of these relations, but they are best observed in the Beaumont quadrangle just to the east.

\section{Geophysical Investigations}

Gravity and aeromagnetic investigations have been conducted in the El Casco quadrangle in support of groundwater investigations, seismic-hazard assessments, and geologic studies to better characterize the 3-dimensional structure of the region. On sheet 3 we show gravity contours created from a 300-m grid based on 244 gravity measurements within the quadrangle, edited slightly from the compilation of Langenheim and others (2006). These data include 128 gravity measurements collected by the USGS since 2000; 54 measurements collected by the University of California, Riverside; and 22 National Geodetic Survey stations - the remaining data are derived from Langenheim and others (1991). Gravity stations are nonuniformly distributed in the region.

The datum of observed gravity for this map is the International Gravity Standardization Net of 1971 (IGSN 71) that was described by Morelli (1974); the reference ellipsoid is the Geodetic Reference System of 1967 (GRS67; International Association of Geodesy and Geophysics, 1971). The observed 
gravity data were reduced to free-air anomalies using standard formulas (for example, Telford and others, 1976). Bouguer, curvature, and terrain corrections to a radial distance of $166.7 \mathrm{~km}$ were applied to the free-air anomaly at each station to determine the complete Bouguer anomalies at a standard reduction density of $2,670 \mathrm{~kg} / \mathrm{m}^{3}$ (Plouff, 1977). An isostatic correction was then applied to remove the long-wavelength effect of deep crustal and (or) upper mantle masses that isostatically support regional topography. The isostatic correction assumes an Airy-HeisKanen model of isostatic compensation (HeisKanen and Vening-Meinesz, 1958). An isostatic correction using a sea-level crustal thickness of 25 $\mathrm{km}$, a crustal density of $2,670 \mathrm{~kg} / \mathrm{m}^{3}$, and a mantle-crust density contrast of $400 \mathrm{~kg} / \mathrm{m}^{3}$ was applied to the gravity data to remove long-wavelength crustal gravity effects of topographic loading (Jachens and Griscom, 1985). The resulting isostatic residual gravity values should reflect lateral variations of density within the mid- to upper crust (Simpson and others, 1986); this statement is supported by the favorable comparison of the observed isostatic gravity field with that predicted from seismic velocities in southern California (Langenheim and Hauksson, 2001). A color-contour representation of the isostatic gravity field is shown in figure 42.

Accuracy of the data is estimated to be about \pm 0.2 to $\pm 0.5 \mathrm{mGal}$ based on comparison of observed gravity values at duplicate stations from different data sources and expected error resulting from the total terrain correction. Total terrain corrections for the stations collected for this study ranged from 1.3 to $6.1 \mathrm{mGal}$, with an average of $2.1 \mathrm{mGal}$. If the error from the terrain correction is considered to be 5 to 10 percent of the terrain correction, the largest error expected for the data is $0.6 \mathrm{mGal}$. However, the possible error caused by the terrain correction is small (less than $0.2 \mathrm{mGal}$ ) for most of the stations.

To help delineate structural trends and gradients expressed in the gravity field, a computer algorithm was used to locate the maximum horizontal gravity gradient (Cordell and Grauch, 1985; Blakely and Simpson, 1986). Concealed basin faults beneath the valley areas on the El Casco quadrangle were mapped using horizontal gradients in the gravity field. Gradient maxima occur approximately over steeply dipping contacts that separate rocks of contrasting densities. For moderate to steep dips $\left(45^{0}\right.$ to vertical), the horizontal displacement of a gradient maximum from the top edge of an offset horizontal layer is always less than, or equal to, the depth to the top of the source (Grauch and Cordell, 1987). 


\section{Outline of Geologic History}

Table 4. Outline of geologic events affecting map units in El Casco quadrangle.

\begin{tabular}{|c|c|c|}
\hline Geologic cycle & Structural or genetic event & Age \\
\hline \multirow[t]{5}{*}{$\begin{array}{l}\text { Evolution of San } \\
\text { Timoteo Creek } \\
\text { drainage system }\end{array}$} & $\begin{array}{l}\text { Late Quaternary dissection and sediment aggradation lead to } \\
\text { modern landscape of San Timoteo Canyon drainage (Kendrick, } \\
\text { 1999; Kendrick and others, 2002) }\end{array}$ & $\sim 10$ ka to present \\
\hline & $\begin{array}{l}\text { Thrust- and tear-fault displacements within San Gorgonio Pass } \\
\text { Fault zone (Cherry Valley Fault and associated structures) collapse } \\
\text { Qvof and Qof depositional system, leading to erosional dissection } \\
\text { of present San Timoteo Canyon }\end{array}$ & $\sim 250 \mathrm{ka}$ \\
\hline & $\begin{array}{l}\text { Middle Pleistocene alluvial-fan system (units Qvof and Qof and } \\
\text { their axial-valley equivalents) initiated on landscape overlying the } \\
\text { sedimentary deposits of Live Oak Canyon; deposition occurs in } \\
\text { subsiding basin formed in hanging wall of San Timoteo Fault zone } \\
\text { (NE part of El Casco quadrangle) and in valleys eroded into } \\
\text { footwall (central part of quadrangle) }\end{array}$ & $\sim 600 \mathrm{ka}$ \\
\hline & $\begin{array}{l}\text { Down-to-the-NE displacements on San Timoteo Fault zone lead to } \\
\text { basinal subsidence to NE and dissection of former Live Oak } \\
\text { Canyon depositional system }\end{array}$ & $\sim 700 \mathrm{ka}$ \\
\hline & $\begin{array}{l}\text { Live Oak Canyon depositional system terminated by NE-tilting } \\
\text { related to San Timoteo Anticline; unconformity and residual soil } \\
\text { (unit Qvors) develop on top of the sedimentary deposits of Live } \\
\text { Oak Canyon }\end{array}$ & $\sim 700 \mathrm{ka}$ \\
\hline \multirow{5}{*}{$\begin{array}{l}\text { Evolution of San } \\
\text { Jacinto Fault zone, } \\
\text { with attendant } \\
\text { structural and } \\
\text { depositional events }\end{array}$} & $\begin{array}{l}\text { Claremont and Casa Loma strands of San Jacinto Fault zone } \\
\text { succeed Moreno Valley strand, producing } \sim 16 \mathrm{~km} \text { of right slip }\end{array}$ & $\sim 700$ to $\sim 900 \mathrm{ka}$ \\
\hline & $\begin{array}{l}\text { Inception of early Pleistocene alluvial-fan system (the sedimentary } \\
\text { deposits of Live Oak Canyon) north of ridgeline formed on north } \\
\text { limb of San Timoteo Anticline; this event marks initiation of San } \\
\text { Timoteo Creek drainage basin, including NE-heading tributaries } \\
\text { that extended well into the San Bernardino Mountains. The } \\
\text { sedimentary deposits of Live Oak Canyon unit buttresses } \\
\text { unconformably against highground of San Timoteo Badlands }\end{array}$ & $\sim 1.2 \mathrm{Ma}$ \\
\hline & $\begin{array}{l}\text { Low-angle down-to-the-north displacements on Laborde Canyon } \\
\text { Fault zone juxtapose San Timoteo formation (hanging wall) } \\
\text { against Mt. Eden formation (footwall); faulting accompanies } \\
\text { growth of San Timoteo Anticline }\end{array}$ & $\sim 1.2 \mathrm{Ma}$ \\
\hline & $\begin{array}{l}\text { Inception of San Jacinto Fault zone, Moreno Valley strand, } \\
\text { producing } \sim 10 \mathrm{~km} \text { of right slip that displaces lower member San } \\
\text { Timoteo formation }\end{array}$ & $\sim 1.2$ to $\sim 1.5 \mathrm{Ma}$ \\
\hline & $\begin{array}{l}\text { Initiation of San Timoteo Anticline; folding continues throughout } \\
\text { duration of slip on San Jacinto Fault zone, and leads to a } \\
\text { topographic uplift that separates the deforming San Timoteo } \\
\text { sequence from alluviating terrane to the NE. }\end{array}$ & $\sim 1.2$ to $\sim 1.5 \mathrm{Ma}$ \\
\hline
\end{tabular}


Table 4. Outline of geologic events affecting map units in El Casco quadrangle.-Continued

\begin{tabular}{|c|c|c|}
\hline Geologic cycle & Structural or genetic event & Age \\
\hline & $\begin{array}{l}\text { Reverse slip on Mt. Eden and Eden Hot Springs Fault zones } \\
\text { synchronous with or slightly preceding inception of San Jacinto } \\
\text { Fault zone and development of San Timoteo Anticline. Reverse } \\
\text { faulting continues as fold grows, and results in uplift of Mt. Eden } \\
\text { crystalline inselberg. Reverse faults probably break San Timoteo } \\
\text { formation, but are concealed beneath low-angle normal slip faults } \\
\text { of Laborde Canyon Fault zone }\end{array}$ & $\sim 1.2$ to $\sim 1.5 \mathrm{Ma}$ \\
\hline \multirow[t]{3}{*}{$\begin{array}{l}\text { San Timoteo } \\
\text { formation } \\
\text { depositional system } \\
\text { established as a } \\
\text { major southeast- } \\
\text { directed braidplain } \\
\text { complex }\end{array}$} & $\begin{array}{l}\text { Proximal braidplain deposition replaced by distal braidplain } \\
\text { deposition (San Timoteo formation, upper member). Former SE- } \\
\text { oriented braidplain gradually replaced by SW-oriented braidplain } \\
\text { where sediment is derived from Santa Ana River drainage in San } \\
\text { Bernardino Mountains (Morton and others, 1986; Morton and } \\
\text { Matti, 1993; Matti and Morton, 1993) }\end{array}$ & $\begin{array}{l}\text { latest Pliocene to } \\
\text { early Pleistocene } \\
(\sim 1.6 \mathrm{Ma})\end{array}$ \\
\hline & $\begin{array}{l}\text { Progradation of proximal braidplain setting southeastward yields } \\
\text { sheeted conglomerate deposits of middle member, San Timoteo } \\
\text { formation; tectonic or climatic basis for progradation not known; } \\
\text { event is time-transgressive, older to the NW and younger to the SE } \\
\text { (Albright, 1999) }\end{array}$ & $\begin{array}{l}\text { middle Pliocene } \\
(\sim 3 \text { Ma to } \sim 1.7 \\
\text { Ma) }\end{array}$ \\
\hline & $\begin{array}{l}\text { Inception of braidplain system (lower member, unit Tstls). } \\
\text { Braidplain drains into playa-lake system (fine-grained unit, unit } \\
\text { Tstlf) that intervenes between braidplain and San Jacinto } \\
\text { Mountain massif to the southeast; Gulf of California is ultimate } \\
\text { base level for this depositional system (Matti and Morton, 1993). } \\
\text { Braidplain complex includes "vanished-fan" deposits of Morton } \\
\text { and Matti (1989), a western lobe of the San Timoteo system that } \\
\text { probably drained into the Pacific Ocean }\end{array}$ & $\begin{array}{l}\text { earliest Pliocene } \\
(\sim 4.9 \mathrm{Ma})\end{array}$ \\
\hline $\begin{array}{l}\text { Evolution of Mt. } \\
\text { Eden formation } \\
\text { depositional system }\end{array}$ & $\begin{array}{l}\text { Deposition of Mt. Eden formation on Peninsular Ranges } \\
\text { landscape, including fluvial, colluvial, mass-wasting, and } \\
\text { lacustrine processes. Sediment derived both locally and from } \\
\text { bedrock sources south of future trace of San Jacinto Fault zone }\end{array}$ & $\begin{array}{l}\text { late Miocene }(<10 \\
\text { Ma?) to latest } \\
\text { Miocene } \sim 5 \mathrm{Ma})\end{array}$ \\
\hline \multirow{3}{*}{$\begin{array}{l}\text { Geologic events } \\
\text { prior to late } \\
\text { Neogene }\end{array}$} & $\begin{array}{l}\text { Intrusion of granitoid magma to yield plutonic map units Ktlc, } \\
\text { Mzme, and Khg }\end{array}$ & late Cretaceous \\
\hline & $\begin{array}{l}\text { Metamorphism of marine sedimentary rock to form units } \mathrm{m} \text { and } \\
\mathrm{ms}\end{array}$ & Cretaceous \\
\hline & Deposition of marine sediment as protolith for units $\mathrm{m}$ and $\mathrm{ms}$ & Paleozoic \\
\hline
\end{tabular}

\section{Subsurface Borings and Geotechnical Investigations}

Subsurface investigations have been conducted locally in the El Casco quadrangle and in the surrounding area; the location of some of these are shown on the geologic map. Waring (1919) describes water wells in the San Jacinto Valley; Shuler (1953, p. 76-79) discusses oil-exploration wells drilled in the 1920's. Table 5 lists these borings and their approximate locations, and their position on sheet 1 are from Shuler's geologic map. One of these borings (Beaumont Midway Oil Company) reportedly penetrated $5358^{\prime}$ of sedimentary section without encountering basement, and at 2250' subsurface encountered hydrocarbon-bearing sandy and muddy rock thought to be marine in origin. Caltrans 
conducted boring investigations for over- and under-crossings of Interstate Highway 10. Geotechnical investigations conducted by private-sector consultants are on file with the Riverside County Geologist (for example, Rasmussen and Associates, 1988a,b; CHJ Inc., 1988, 2004; Petra Consultants, 2004).

Rewis and others (2006) describe geophysical and lithologic logs from water wells in the San Timoteo Creek drainage basin and from the Beaumont Plain area.

Table 5. Listing of deep exploratory subsurface borings drilled in greater San Timoteo Badlands area (derived from Shuler, 1953, p. 78).

\begin{tabular}{|l|l|l|l|l|}
\hline \multicolumn{1}{|c|}{ Company name } & \multicolumn{1}{c|}{ Quadrangle } & \multicolumn{1}{c|}{ Approximate Location } & \multicolumn{1}{c|}{ Date Drilled } & \multicolumn{1}{c|}{ Depth } \\
\hline $\begin{array}{l}\text { Beaumont Midway } \\
\text { Oil Company }\end{array}$ & El Casco 7.5' & Section 16, T2S/R2W & 1922 & $5358^{\prime}$ \\
\hline $\begin{array}{l}\text { Alberta Oil } \\
\text { Company }\end{array}$ & El Casco 7.5' & Section 35, T2S/R2W & $?$ & $3180^{\prime}$ \\
\hline $\begin{array}{l}\text { S.V. Smith } \\
\text { "Haskell” }\end{array}$ & El Casco 7.5' & Section 35, T2S/R2W & 1953 & $1330^{\prime}$ \\
\hline $\begin{array}{l}\text { Moreno Mutual } \\
\text { Irrigation Company }\end{array}$ & El Casco 7.5' & $\begin{array}{l}\text { Section 31, T2S/R2W (see } \\
\text { fig. 41 of Shuler, 1953 }\end{array}$ & 1948 & $\begin{array}{l}745^{\prime}(\text { basement at } \\
\left.500^{\prime}\right)\end{array}$ \\
\hline $\begin{array}{l}\text { Moreno Oil } \\
\text { Company }\end{array}$ & El Casco 7.5' & Section 15, T3S/R2W & 1920 & $1700^{\prime}$ \\
\hline $\begin{array}{l}\text { Riverside County } \\
\text { Oil Company }\end{array}$ & Beaumont 7.5' & Section 12, T2S/R1W & 1920 & $2235^{\prime}$ \\
\hline Nuevo Oil Company & Lakeview 7.5' & Section 26, T3S/R2W & 1920 & $2225^{\prime}$ \\
\hline $\begin{array}{l}\text { Cheney Oil Lease } \\
\text { Syndicate }\end{array}$ & Sunnymead 7.5' & Section 14, T2S/R3W & 1923 & $?$ \\
\hline
\end{tabular}




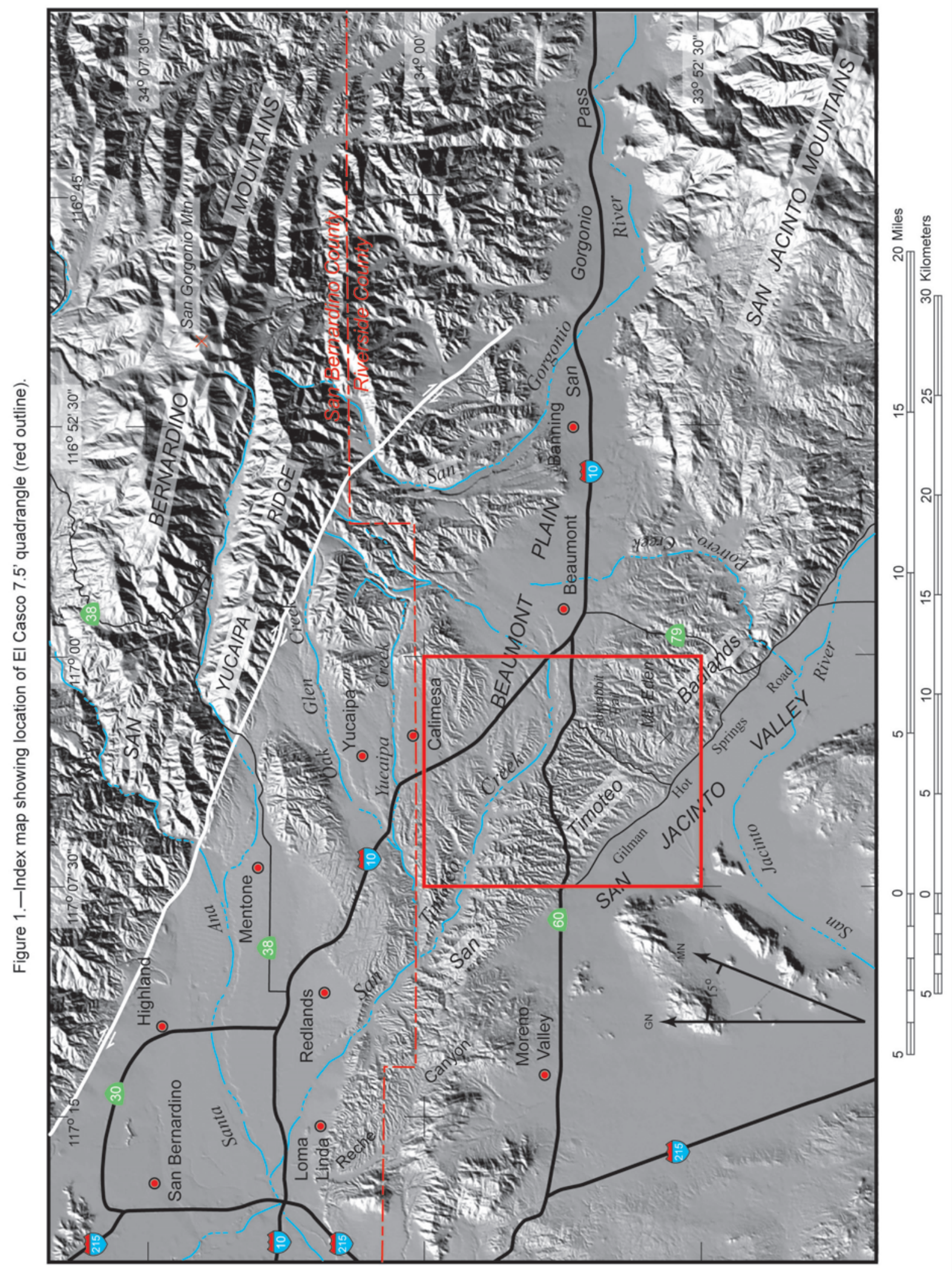

Figure 1. Index map showing location of El Casco quadrangle (rectangle). 


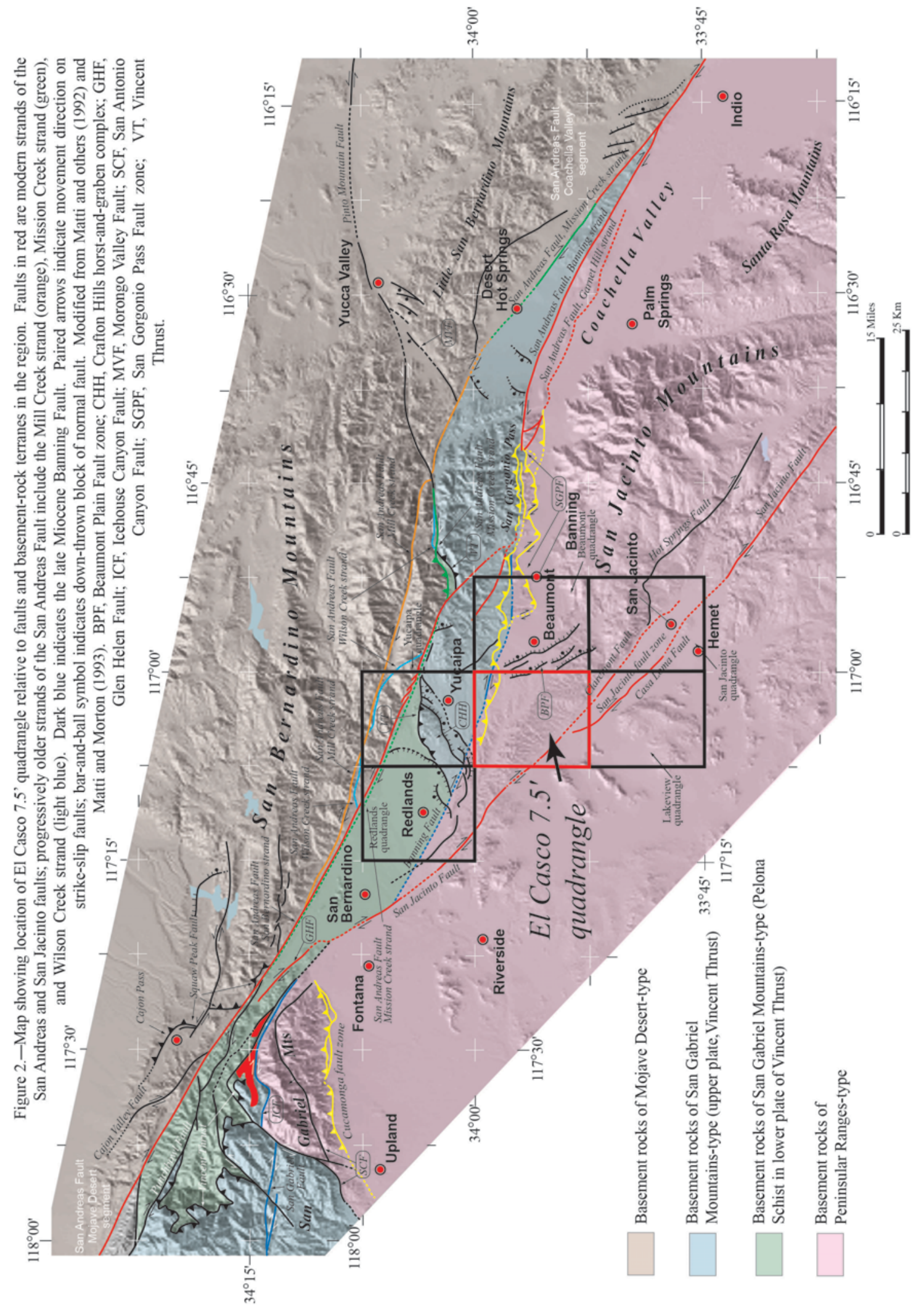

Figure 2. Map showing location of El Casco quadrangle relative to faults and basement-rock terranes in region. 


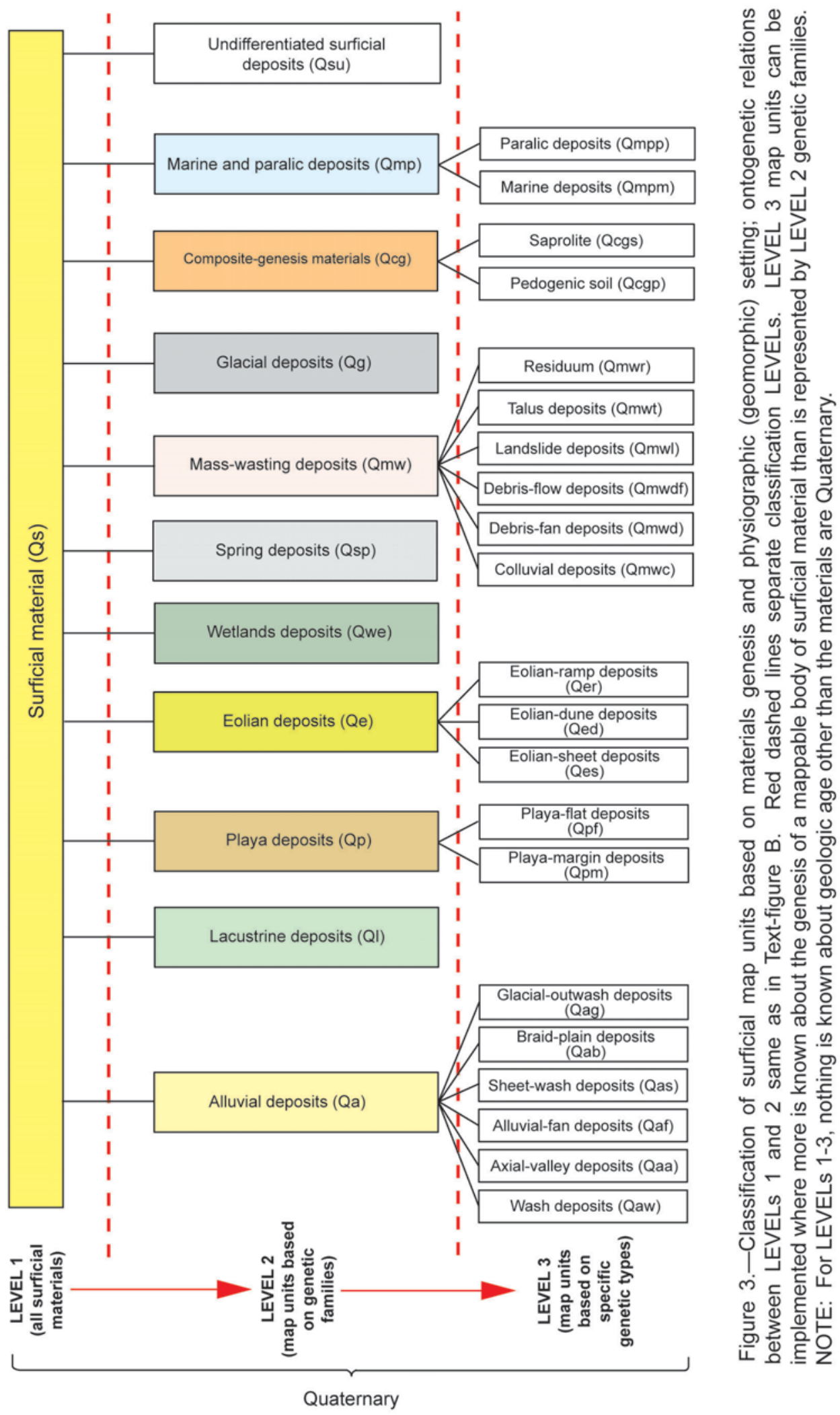

Figure 3. Hierarchical classification of surficial materials for El Casco quadrangle and Inland Empire region based on integration of materials genesis and geologic age. 


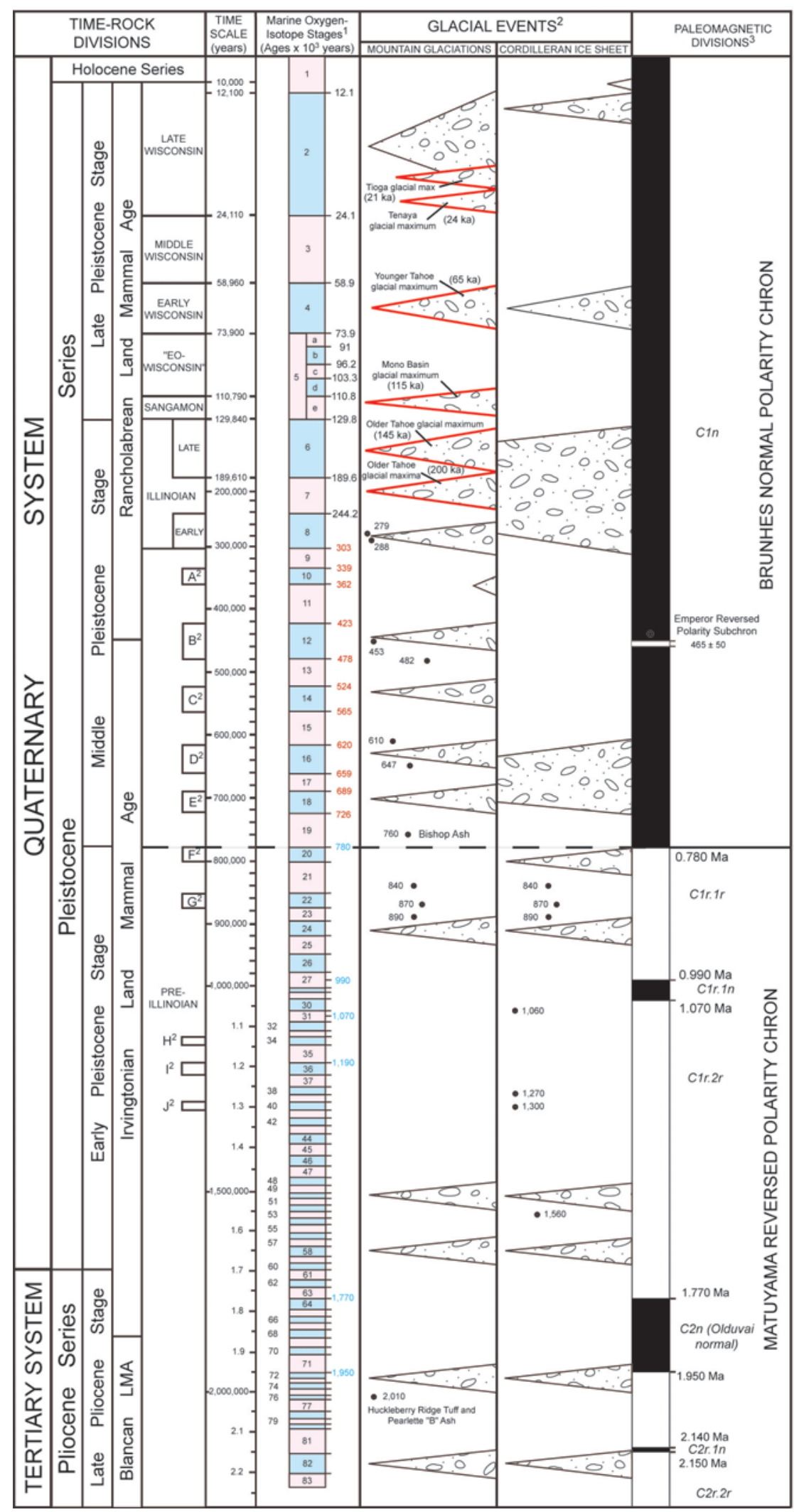

Figure 4.-Chart showing relations among Quaternary time-rock divisions, marine oxygen-isotope stages, glacial events, and paleomagnetic chronology. Figures 5 and 6 show how surficial materials in the El Casco quadrangle are correlated with the chronologies in this figure.

North American Land Mammal Ages adapted from Repenning (1987) and Lundelius and others (1987). North American glacial stages adapted from Bowen and others (1986). Time-rock divisions for Pleistocene Series from Berggren and others (1995a,b). Timescale is not linear: (a) for the interval dating from the present to 200,000 years before present (ybp), the span of time increments is adjusted to accommodate other information on the chart; (b) for the interval between $200,000 \mathrm{ybp}$ to $1,000,000 \mathrm{ybp}$, the time increments are equal; (c) for the interval between 1,000,000 ybp and 2,300,000 ybp the time increments are equal, but not the same as (b).

${ }^{1}$ Marine oxygen-isotope stages adapted from several sources. (a) Stages 1 through base of 7, from Martinson and others, 1987 (black age annotations) based on orbital-tuning of results by Pisias and others (1984); (b) base of Stage 8 through base of Stage 18 from Imbrie and others, 1984 (red age annotations); (c) base of Stage 19 through base of Stage 83 interpolated by us from Figure 2 and Tables 3 and 4 of Shackleton and others, 1990 (blue age annotations from their Table 4).

${ }^{2}$ Sequencing of glacial events (gravel pattern) adapted from two sources. (a) Cordilleran Ice Sheet events and most mountain glaciations (including selected geochronologic age determinations) adapted and modified from Bowen and others (1986, Figure 1); (b) glaciations in the eastern Sierra Nevada Mountains along the southeast boundary of Yosemite National Park adapted from Phillips and others (1990; red outlines and geochronologic dates in parentheses).

3Paleomagnetic divisions adapted from Cande and Kent (1995), with age of Bruhnes-Matuyama boundary and selected Matuyama events determined by Shackleton and others (1990). Age of Emperor Reversed-polarity Subchron from Bowen and others (1986, Figure 1).

Figure 4. Chart showing relations among Quaternary time-rock divisions, marine oxygen-isotope stages, glacial events, and paleomagnetic chronology. 


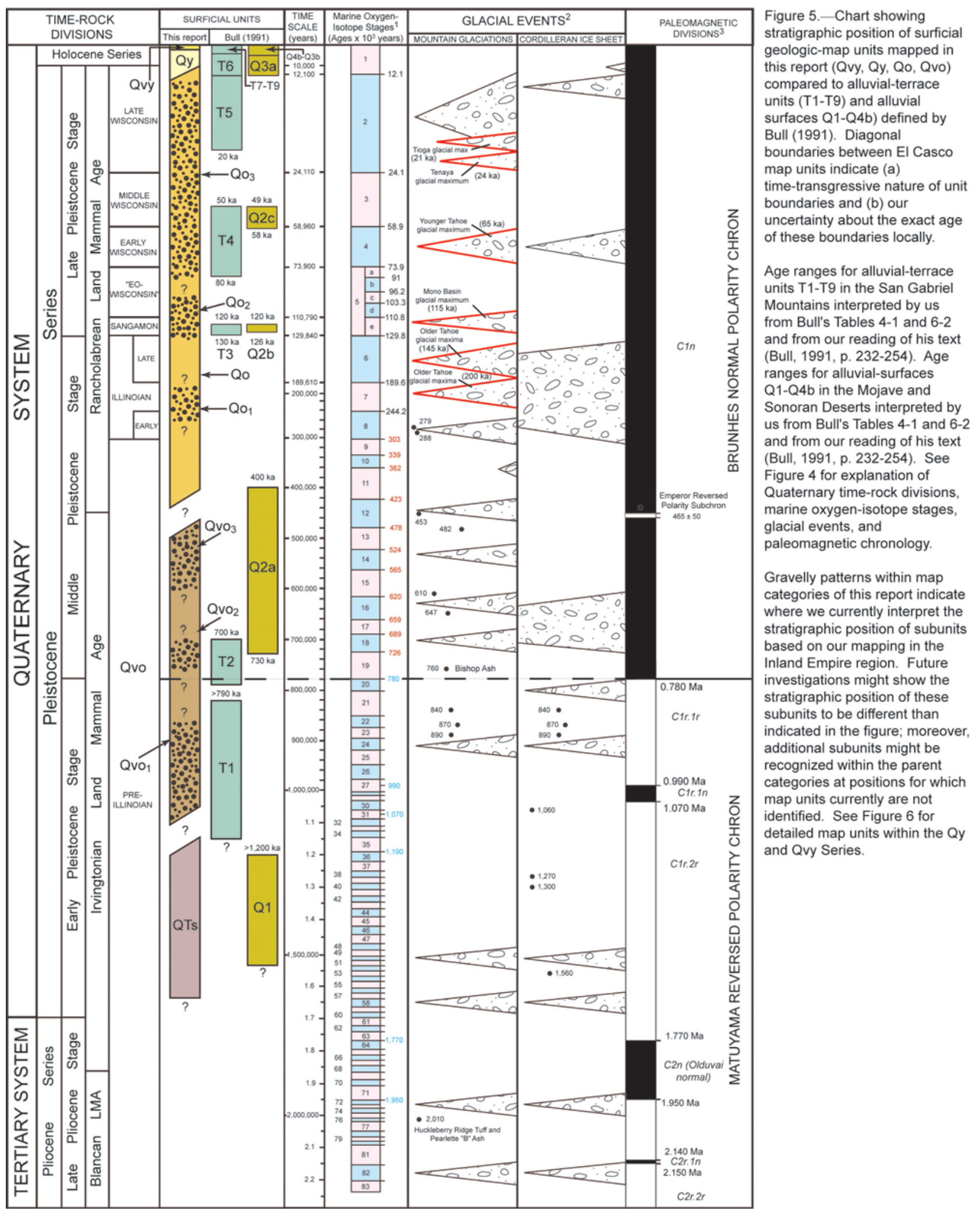

Figure 5. Chart showing stratigraphic position of surficial geologic-map units mapped in this report (Qvy, Qy, Qo, Qvo) compared to alluvial-terrace units (T1-T9) and alluvial surfaces Q1-Q4b) defined by Bull (1991). 


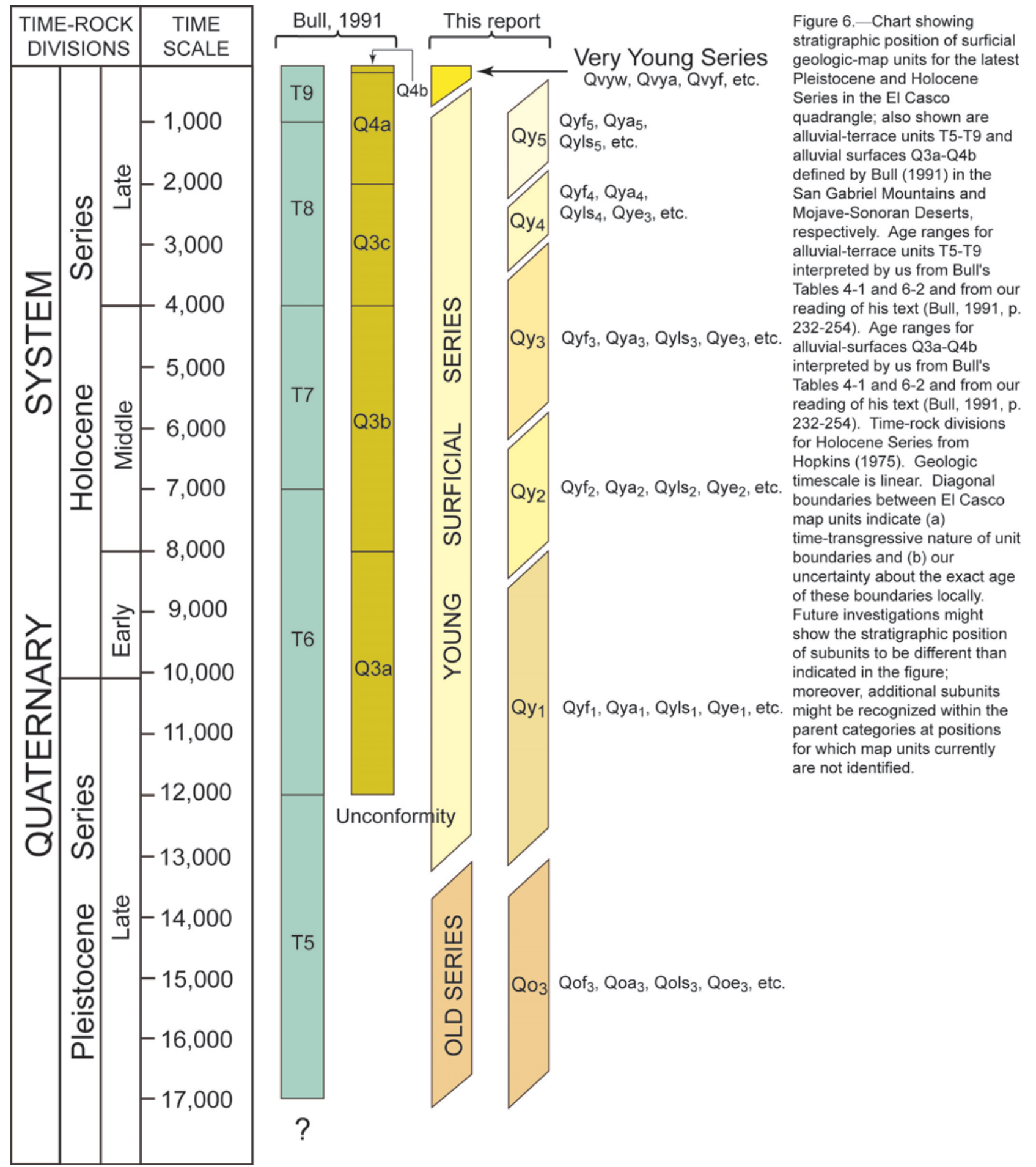

Figure 6. Chart showing stratigraphic position of surficial geologic-map units for uppermost Pleistocene and Holocene Series in El Casco quadrangle. 


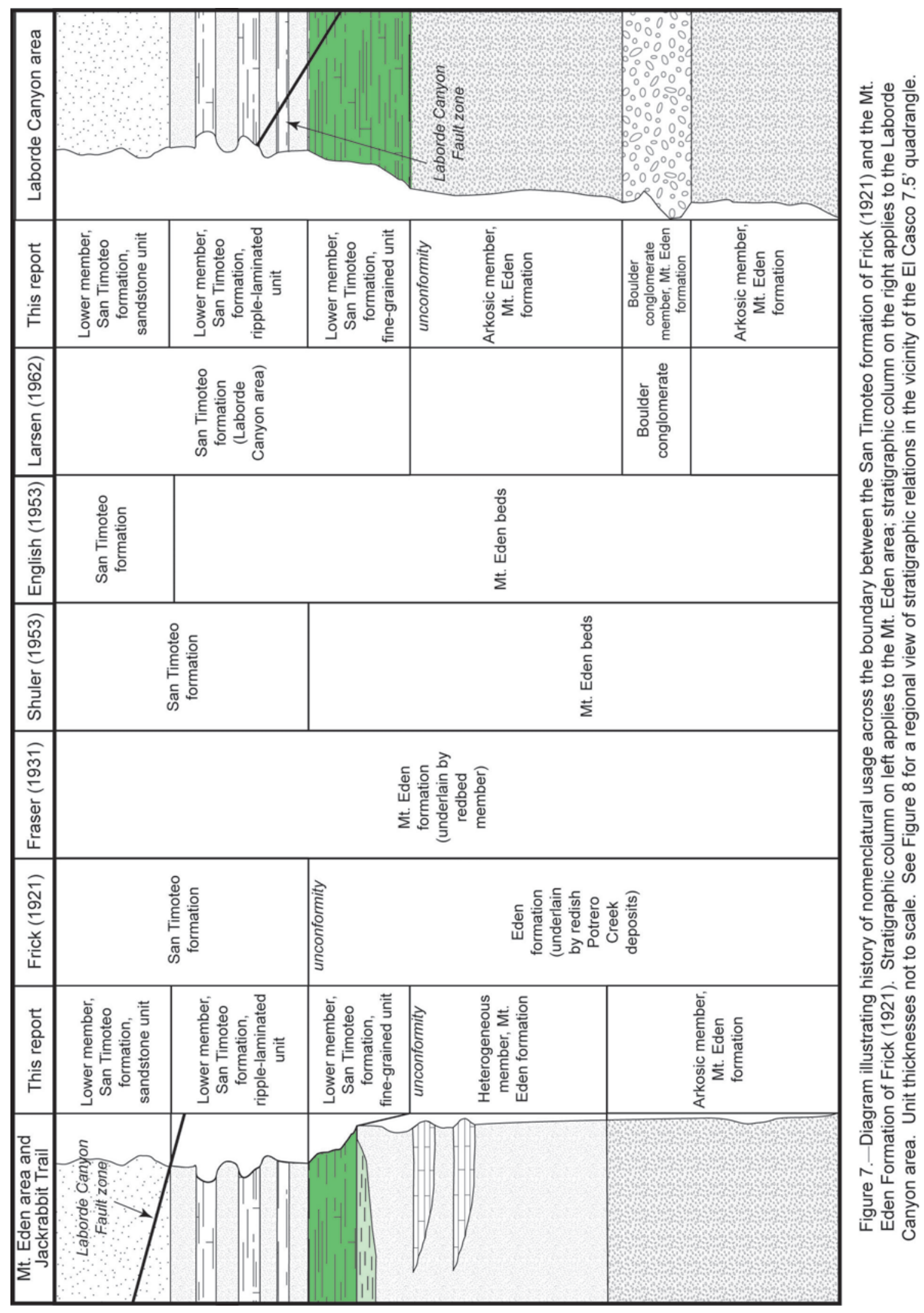

Figure 7. Diagram illustrating history of nomenclatural usage across boundary between the San Timoteo formation of Frick (1921) and the Mt. Eden Formation of Frick (1921). 


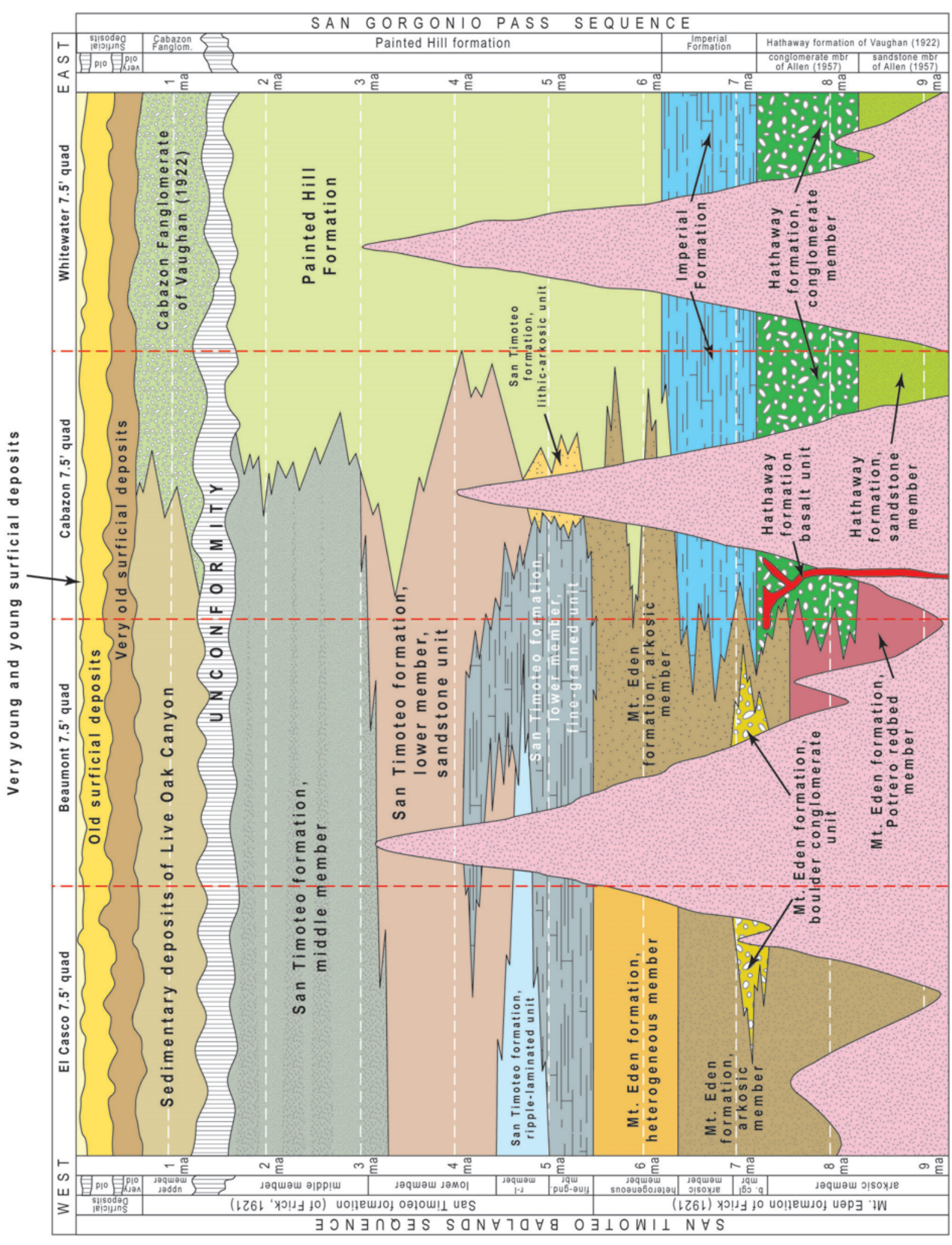

卷 을 음 응 잉 음 ஸू ฆิ 든 हิํํㅇ 흄응 눈 믄 t5

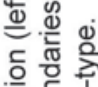

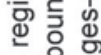
을 뜸 雴 $\frac{5}{\pi}$ ๓ 하 잉 흔 o i 눈 ๗็ 든 응 훙 Ф 这. 产 $\infty$ 응. 은 음듬 贾 30 品 응 屯 훙 흥 离 음 잉 인 ป 엉 혼 है 它 퉁 잉 뭉 1 등 $\infty$ 은 흔든 ن한

Figure 8. Diagram showing late Cenozoic stratigraphic relations between San Timoteo Badlands region (left side of diagram) and San Gorgonio Pass region (right side of diagram). 


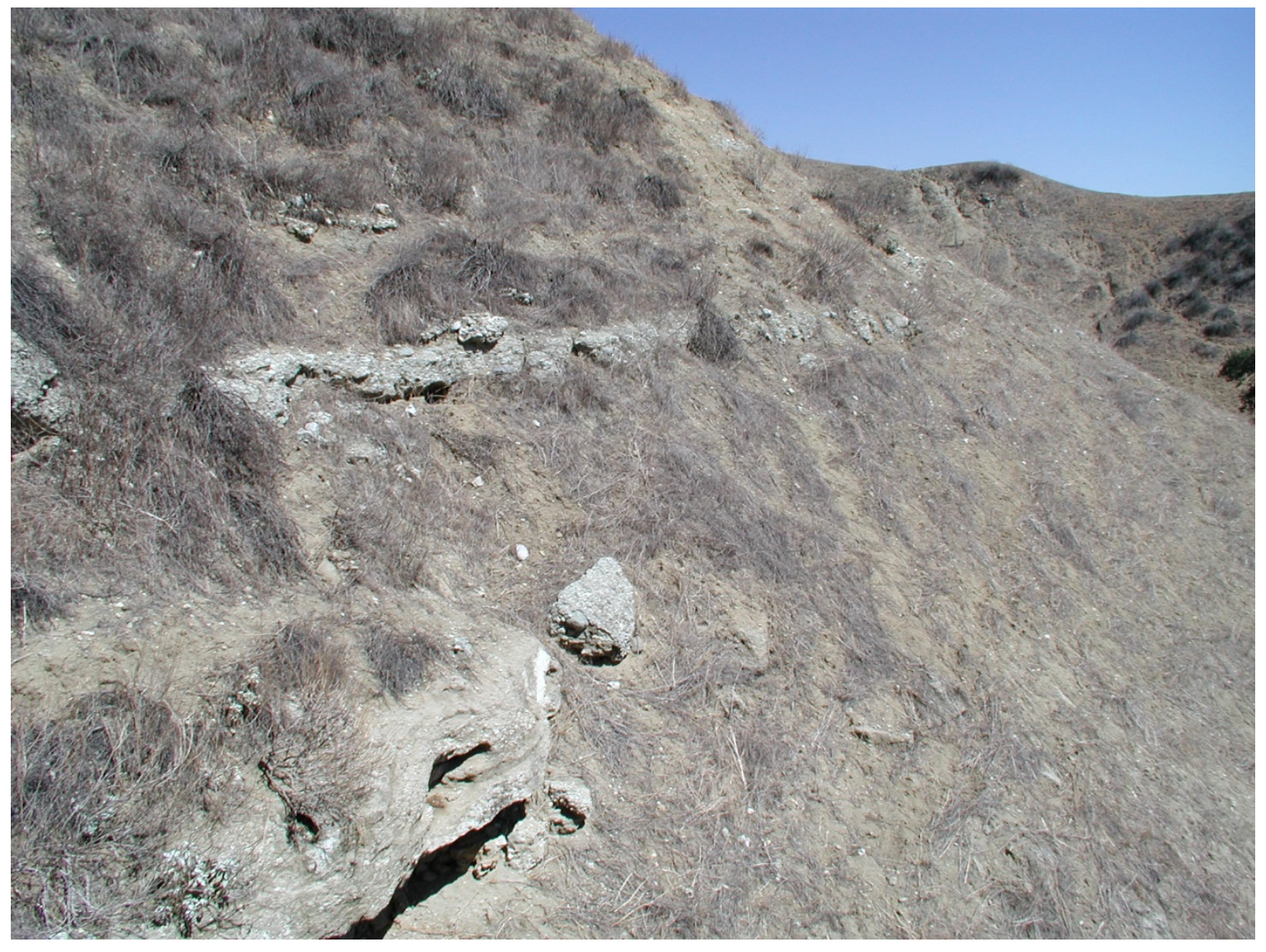

Figure 9. Photograph of the sedimentary deposits of Live Oak Canyon. Note prominent ledge-forming, cemented conglomeratic beds interstratified with finer grained sedimentary materials that form smooth, recessive slopes covered with colluvial material (photograph by J.C. Matti, 11/2007). Location is in El Casco quadrangle, NW1/4 Sec. 22 (T.2 S., R.2 W.), looking east-northeast. 

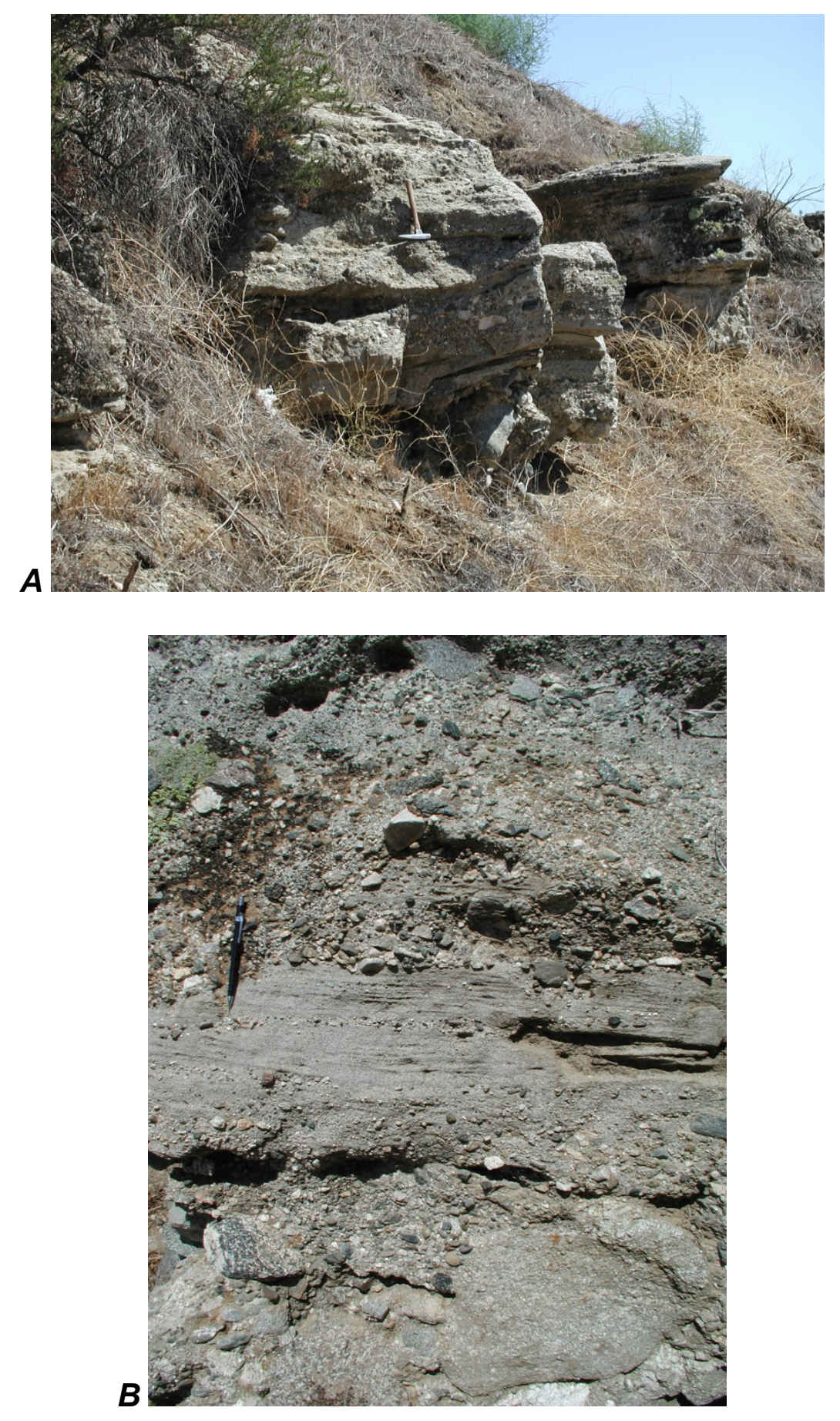

Figure 10. Typical bedding and fabric characteristics of ledge-forming conglomeratic beds in the sedimentary deposits of Live Oak Canyon. A, Typical appearance of cemented, thin- to thick-bedded strata, including sandy layers (hammer head) and conglomeratic layers (shadowed layer beneath hammer head); latter contains pebbleand cobble-size clasts that are matrix-supported (see fig. 10B). B, Close-up view of strata in figure 10A. Pencil straddles boundary between pebble-cobble conglomerate (above) and flat-laminated sandstone and slightly conglomeratic sandstone (below). Conglomeratic layers have imbricated clasts, indicating fluvial origin. Note channelate base (pencil point), indicating scour into underlying sandy rock. In lower part of photograph, cobblepebble conglomerate is matrix-supported layer depicted in figure $10 \mathrm{~A}$. 


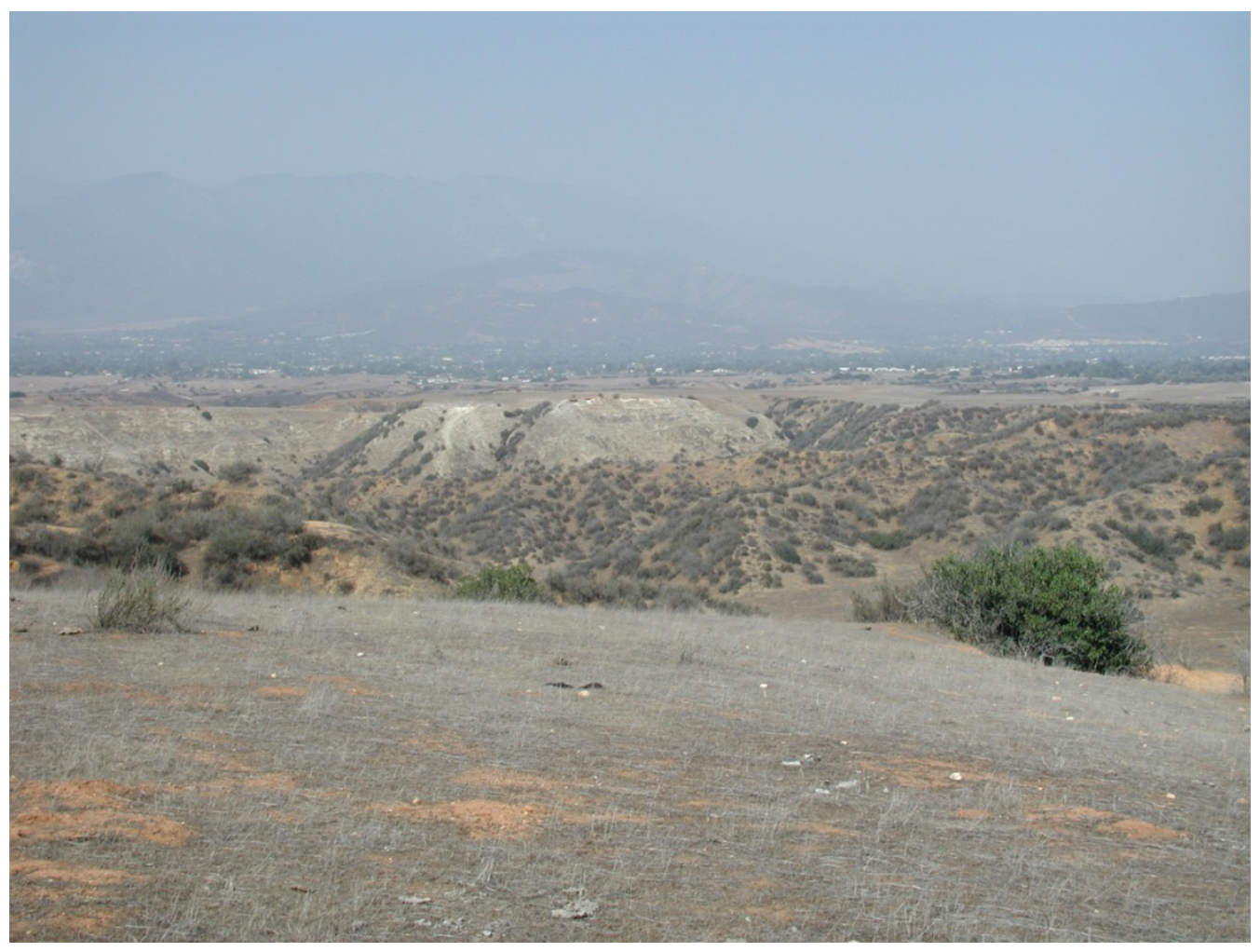

Figure 11. View looking north at white-colored rocks of San Timoteo formation (center middle ground) surrounded by brownish-colored beds of the sedimentary deposits of Live Oak Canyon (unit Qlo) (photograph by J.C. Matti, 6/2002). Photo taken in Sec. 17 (T. 2 S., R. 2 W.) of El Casco 7.5' quadrangle looking north into Yucaipa 7.5' quadrangle. In foreground, reddish-colored ground surface represents residual soil (unit Qvors) that caps erosional landscape developed atop gently north-tilted unit Qlo. Note white aplitic clasts on ground surface. In this view, Live Oak Canyon beds buttress unconformably against-and locally overtop-white-colored highground of the San Timoteo formation, here assigned to the upper member of that unit. Shutt Ranch vertebrate local fauna dated at about 780 to 990 ka (Albright, 1999) occurs in this general location, presumably in Live Oak Canyon beds. 

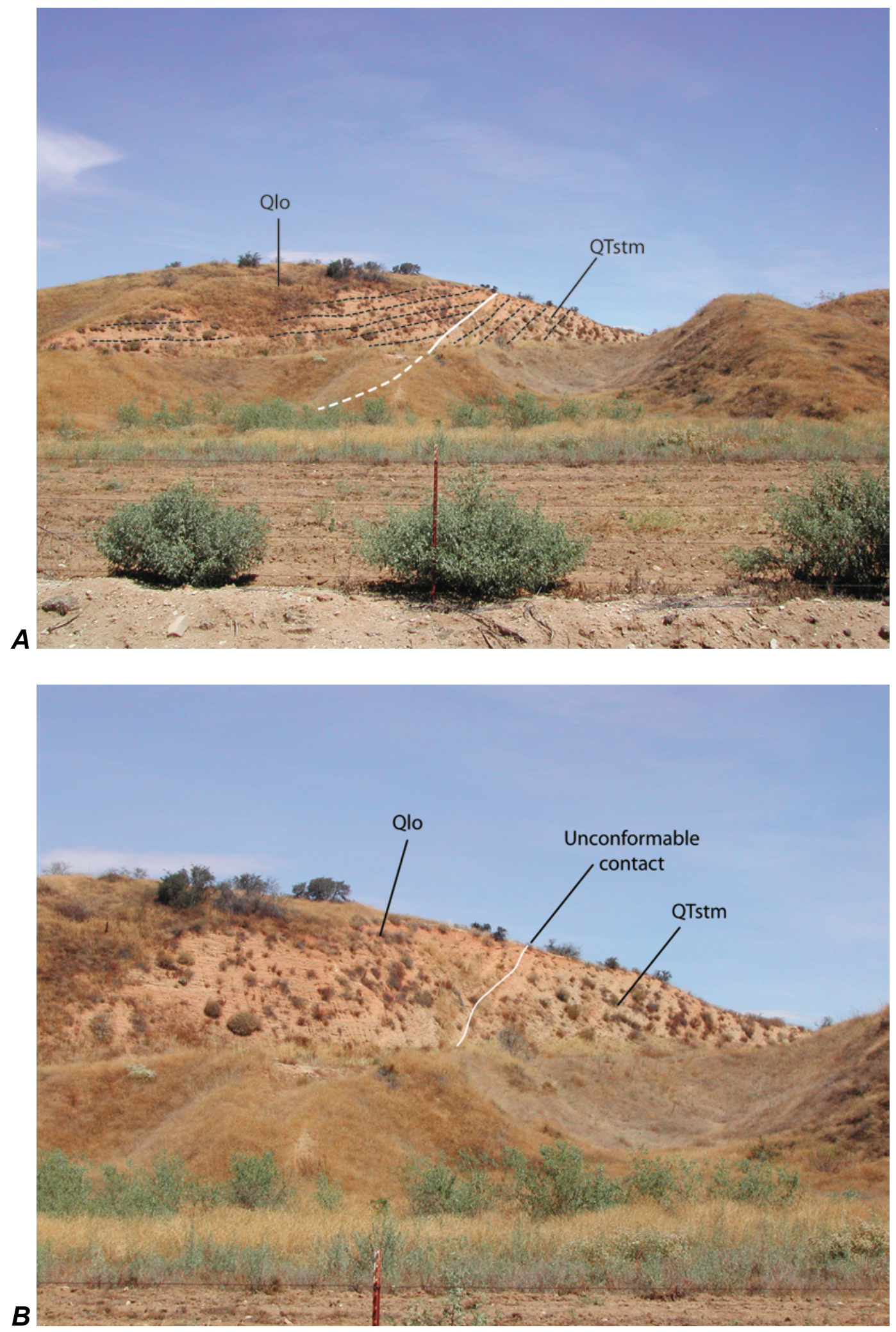

Figure 12. Stratigraphic relations between the sedimentary deposits of Live Oak Canyon (Qlo) and middle member of the San Timoteo formation of Frick (1921) (QTstm); views looking north-northwest in El Casco 7.5' quadrangle (NE $1 / 4$ Sec. 24, T. 2 S., R. 2 W.) a few hundred meters north of Interstate Highway 10 in vicinity of rightangle bends in Singleton Canyon Road. Photographs taken in 2004 by Jay Martin, CHJ, Inc., consultants. A, The 
Figure 12.-Continued

sedimentary deposits of Live Oak Canyon (unit Qlo) on left side of photograph dip gently to moderately northwest (left) away from beds of San Timoteo formation, middle member (unit QTstm) exposed in quarry face and in low hills on right side of photograph; white solid line denotes unconformable contact between two formations; black dashed lines denote approximate orientation of bedding. Unfortunately, this quarry and adjacent hillslopes have been destroyed by grading activities related to new road construction. This photograph by Jay Martin (and that in figure 12B) are only documentary evidence of unconformity once exposed so clearly in quarry face. B, Closer view of quarry face that exposes angular unconformity between Live Oak Canyon beds (Qlo) and underlying strata we assign to middle member of the San Timoteo formation (unit QTstm). See figure 12A for orientation of layering.

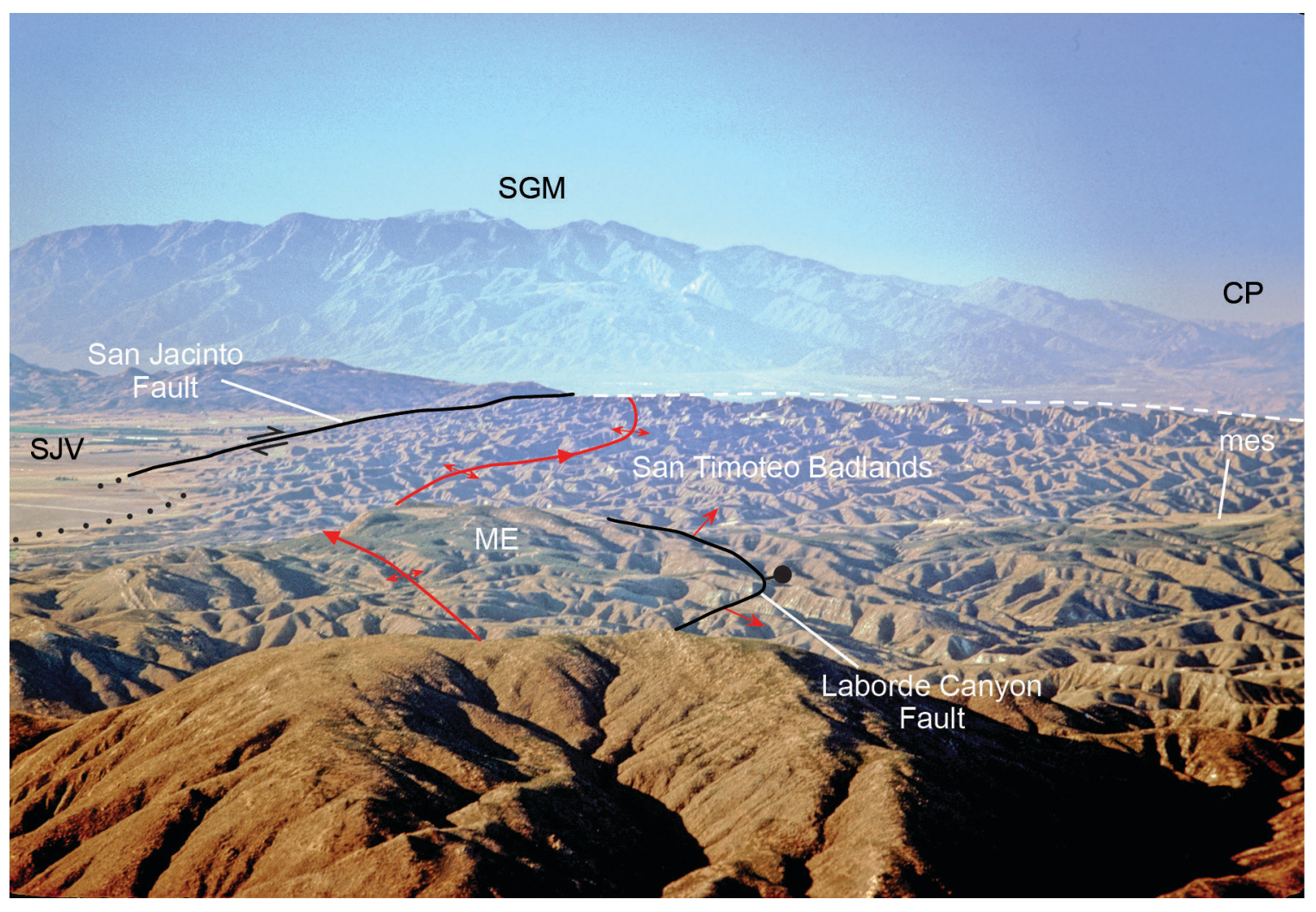

Figure 13. View looking northwest from San Jacinto $7.5^{\prime}$ quadrangle toward San Timoteo Badlands. Mt. Eden (ME) in left middle ground, San Jacinto Valley (SJV) and San Jacinto Fault on left, and San Gabriel Mountains (SGM) and Cajon Pass (CP) on far skyline (photograph by J.C. Matti, 4/1974). El Casco 7.5' quadrangle occupies much of middle ground, which displays badland geomorphology eroded into the San Timoteo formation of Frick (1921). San Timoteo Anticline (red line) warps sedimentary rocks in Badlands, and plunges gently northwest for most of its extent; fold's hinge is cored by crystalline rock of Peninsular Ranges-type in foreground and at Mt. Eden. Barely distinguishable in this view is erosion surface developed on the San Timoteo formation north of Mt. Eden (Mt. Eden surface, mes). This surface is developed on north limb of San Timoteo Anticline, and occurs at lower elevation than crest of San Timoteo Badlands (white dashed line; see text for details and discussion). Northdipping Laborde Canyon Fault not only disrupts sedimentary succession but has dropped Mt. Eden surface down relative to comparable surface capping Mt. Eden massif; red arrows on fault indicate north dip. 


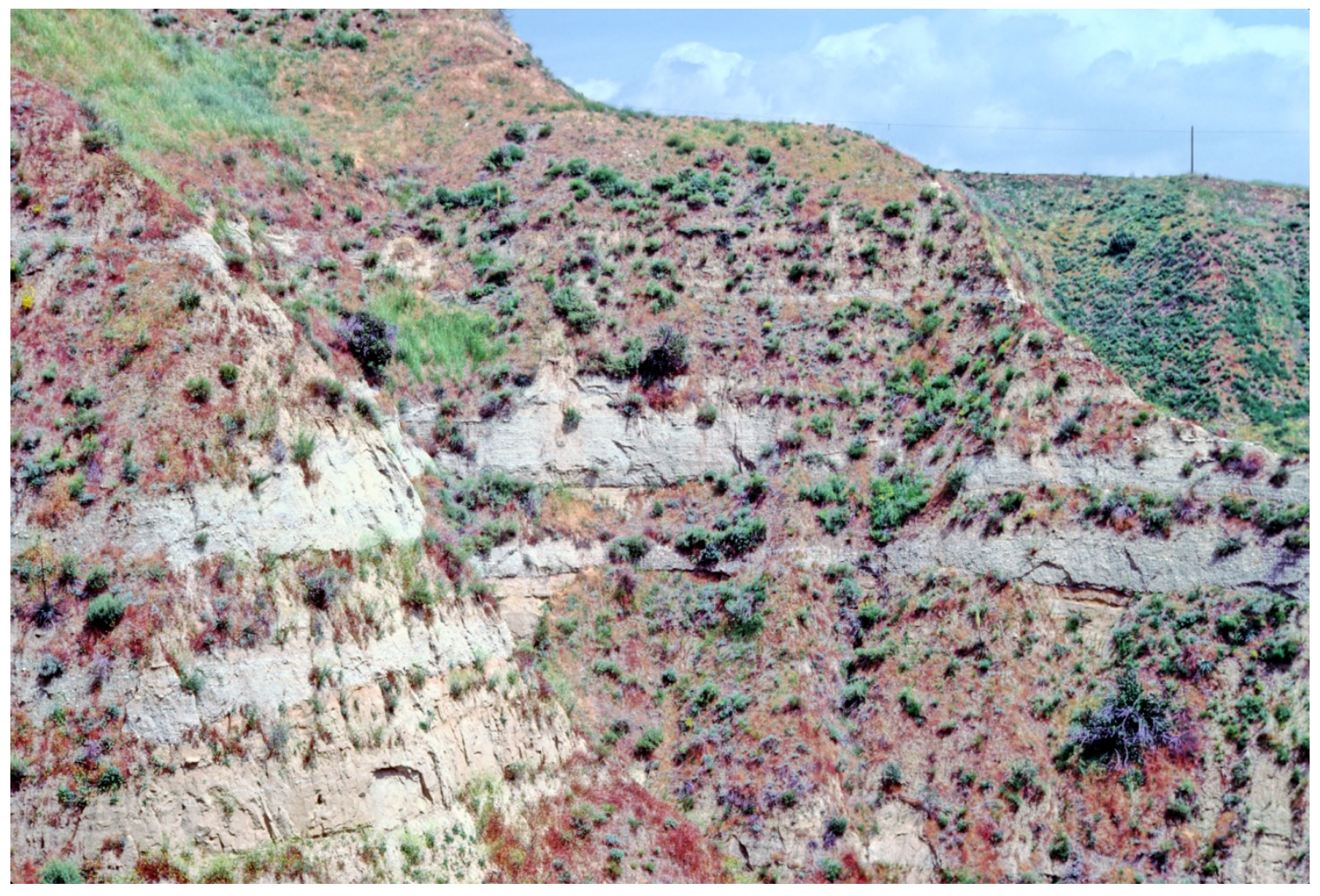

Figure 14. Middle member of San Timoteo formation (unit QTstm). View looking east from Jackrabbit Trail in El Casco 7.5' quadrangle, central part of Sec. 12 , T. 3 S., R. 2 W. (photo by J.C. Matti, 1974). Thick, white, sheet-like layers of conglomerate interbedded with very pale-brown sandy rock (sandstone, slightly conglomeratic sandstone) are typical of middle member (contrast with fig. 16). Downsection, stratigraphic transition into lower member of the San Timoteo formation ( $0.5 \mathrm{~km}$ or so south [to right] of this photo) is gradational and difficult to map. 


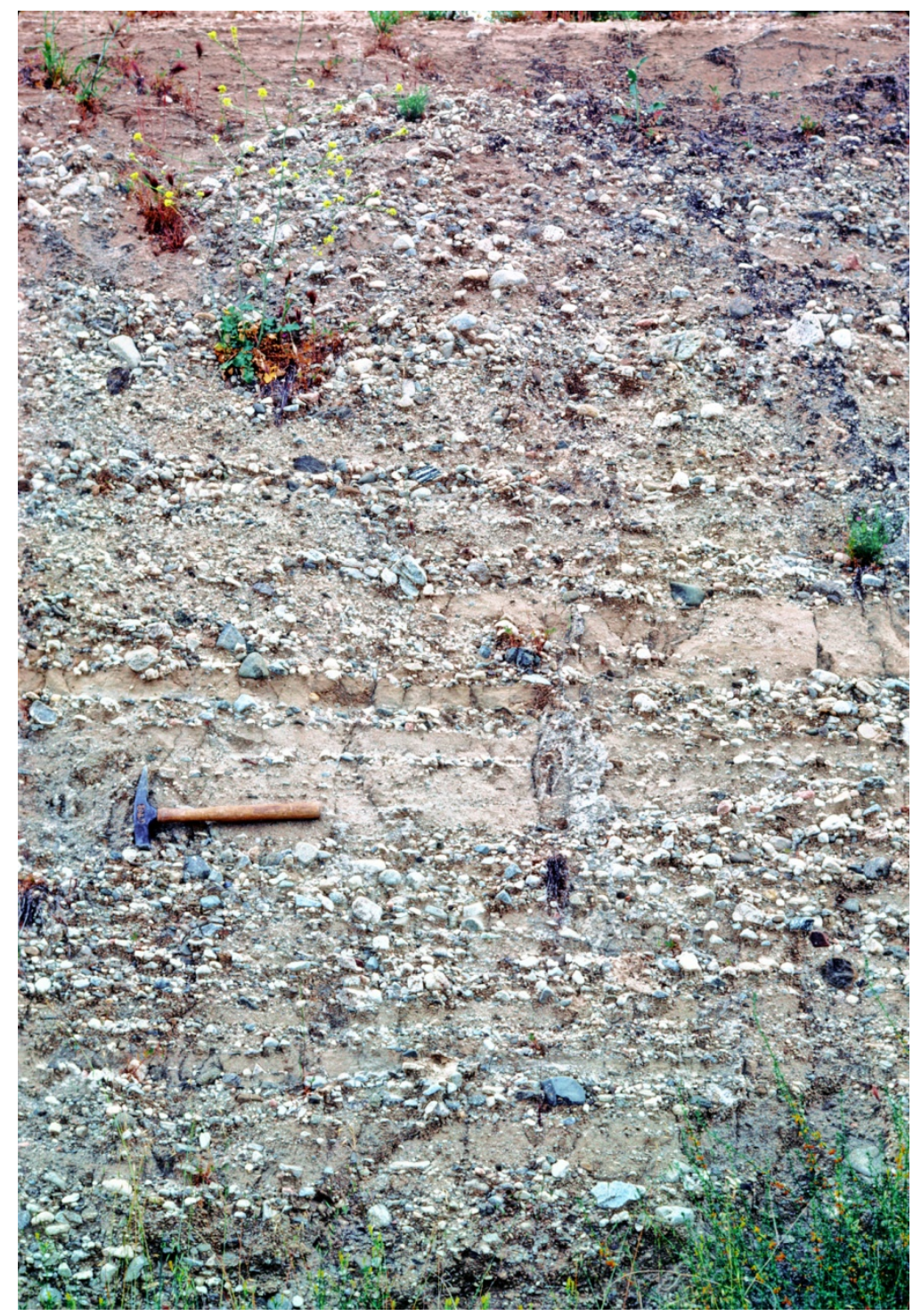

Figure 15. Details of conglomeratic rock in middle member of San Timoteo formation (unit QTstm) in roadcut of Jackrabbit Trail in El Casco 7.5' quadrangle, SW1/4 Sec. 12, T. 3 S., R. 2 W. (photo by J.C. Matti, 1974). Rock mainly is conglomerate and sandy conglomerate, but note very pale-brown sandy rock (sandstone, slightly conglomeratic sandstone) interstratified with coarser rock. Clasts are imbricated, range from pebbles to small cobbles, are subrounded to subangular, and exclusively are San Gabriel Mountains-type crystalline rocks (but no Pelona Schist at this stratigraphic level). 


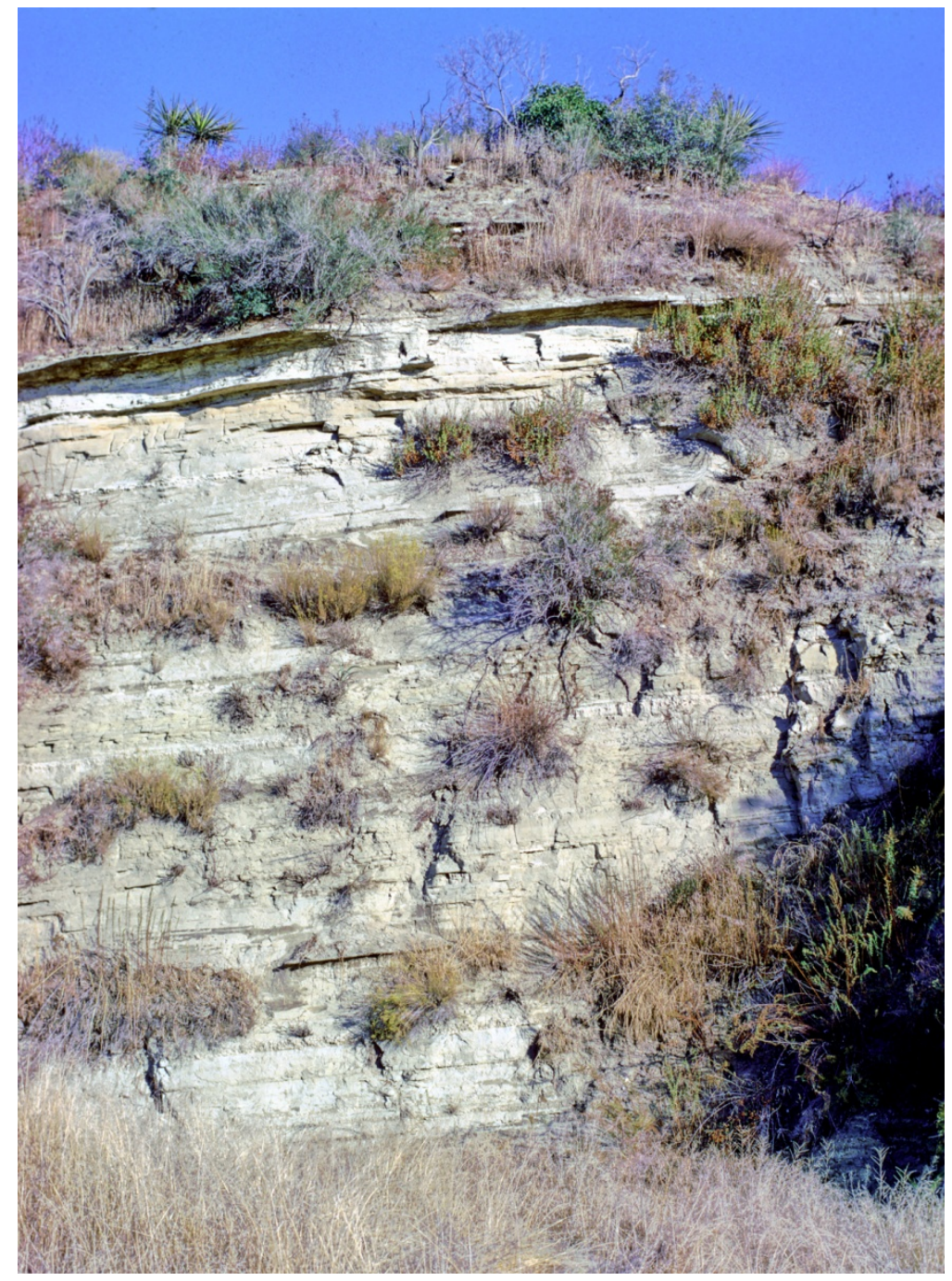

Figure 16. Lower member of San Timoteo formation, sandstone unit (Tstls). View looking north-northeast in vicinity of dirt road, El Casco 7.5' quadrangle, southeast corner of Sec. 13, T. 3 S., R. 2 W. (photo by J.C. Matti, 1974). Sequence is about $6 \mathrm{~m}$ thick, and is typical of this part of lower member. Consists of white to very palebrown fine sandy rock (very fine to medium sandstone), with no conglomeratic layers other than very slightly conglomeratic sandstone; ledge-forming bed is well cemented. Contrast with figs. 14 and 15. 


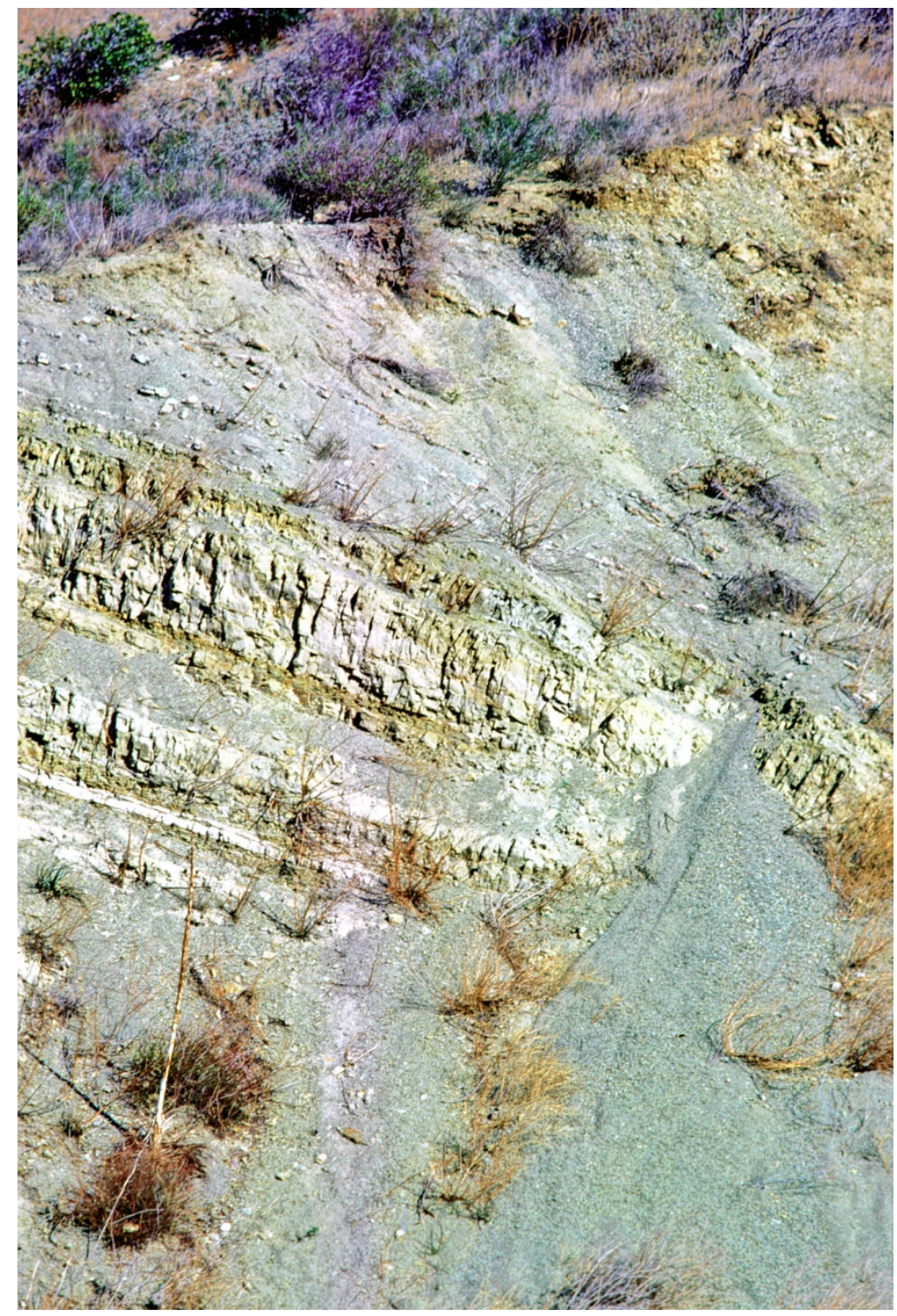

Figure 17. Lower member of San Timoteo formation, sandstone unit (Tstls). El Casco 7.5' quadrangle; view looking northwest in central part of Sec. 29, T. 3 S., R. 1 W. (photo by J.C. Matti, 1974). Sequence is about $6 \mathrm{~m}$ thick, and consists of ledge-forming white to very pale-brown fine sandy rock (very fine to medium sandstone) interlayered with recessive intervals of greenish-gray mudrock (tongues of unit Tstlf). Note absence of conglomeratic rock. 


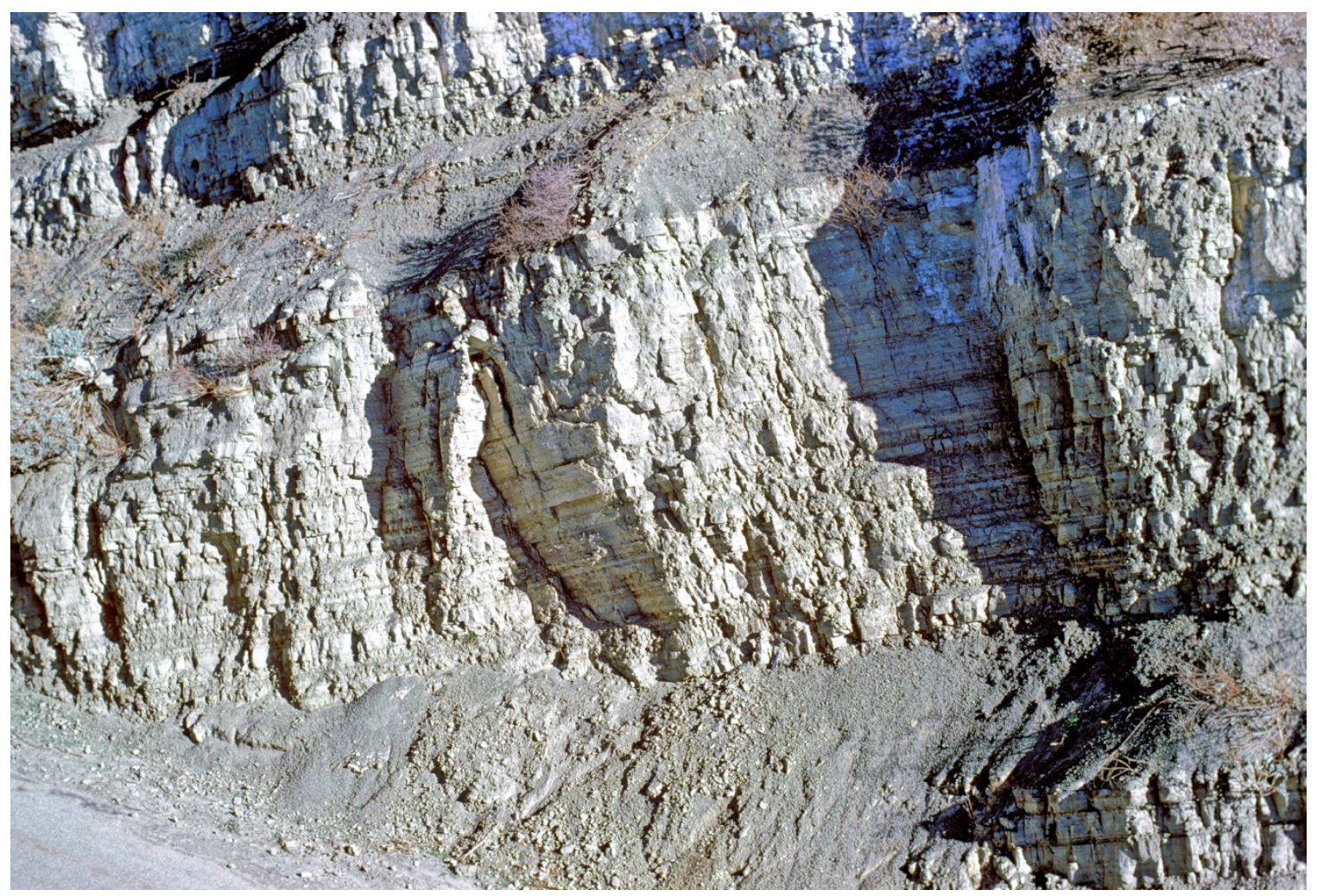

Figure 18. Ripple-laminated unit (Tstlr) of lower member, San Timoteo formation in roadcut of Jackrabbit Trail. View looking northeast in El Casco 7.5' quadrangle, NW11/4 Sec. 23, T. 3 S., R. 2 W. (photo by J.C. Matti, 1974). Compare with PI. 44, figure 3, of Frick (1921). Ledge-forming layers consist of very fine to fine and medium sandstone; recessive layers consist of greenish-gray mudrock (mudstone, claystone, siltstone). Figures 19 and 20 show details from this outcrop series. 


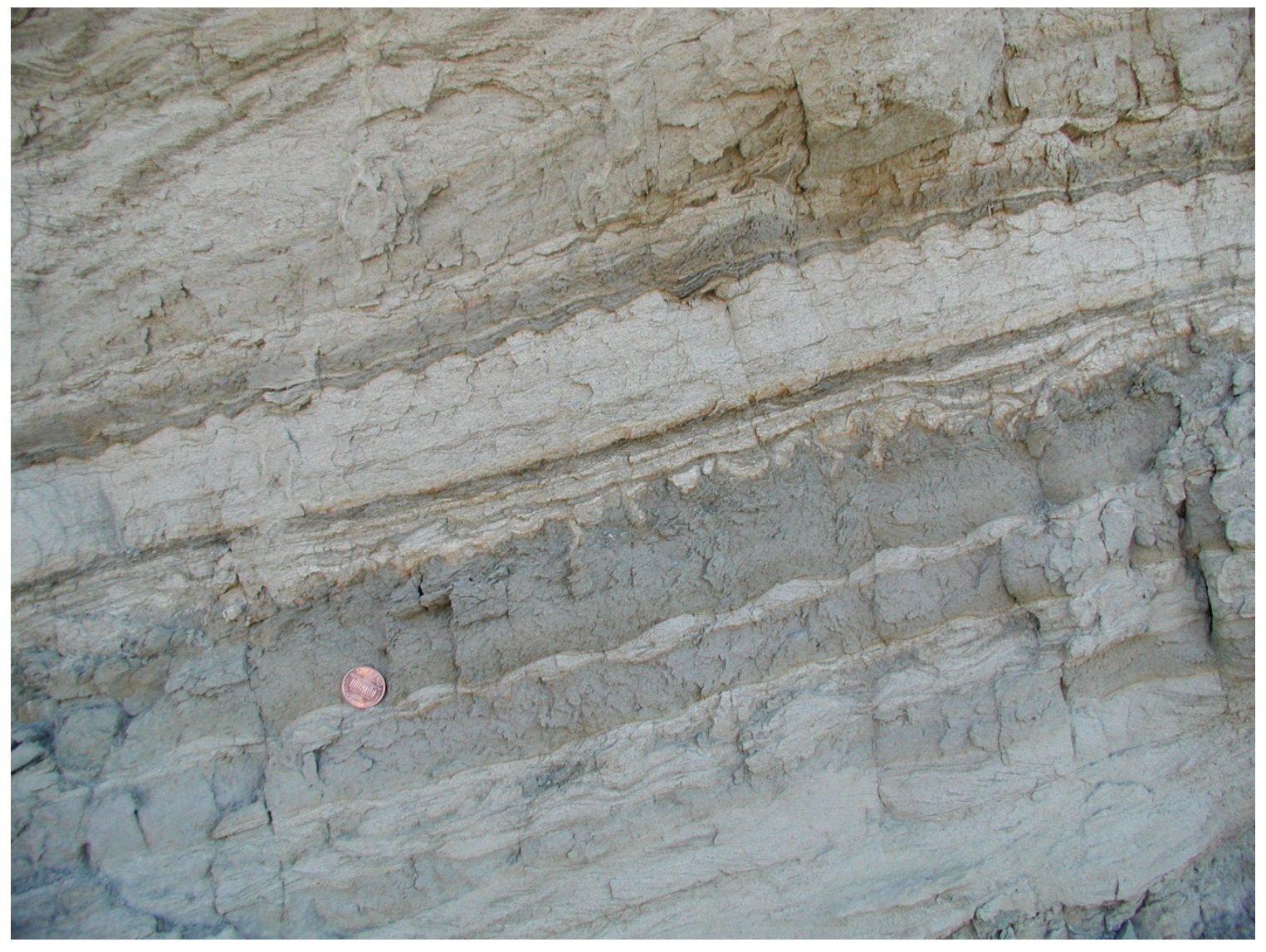

Figure 19. Lithologic details and sedimentary structures, ripple-laminated unit (Tstlr) of San Timoteo formation lower member in roadcut of Jackrabbit Trail. Location: El Casco 7.5' quadrangle, NW11/4 Sec. 23, T. 3 S., R. 2 W. (photo by D.M. Morton, 1999). Greenish-gray intervals are mudrock, white to very pale-brown intervals are fine sandy rock. Note (1) fine cross lamination and delicate ripples preserved in sandy beds (for example, layer beneath coin), and (2) load-and-founder structures beneath sandy layer about $2-3 \mathrm{~cm}$ above coin. 


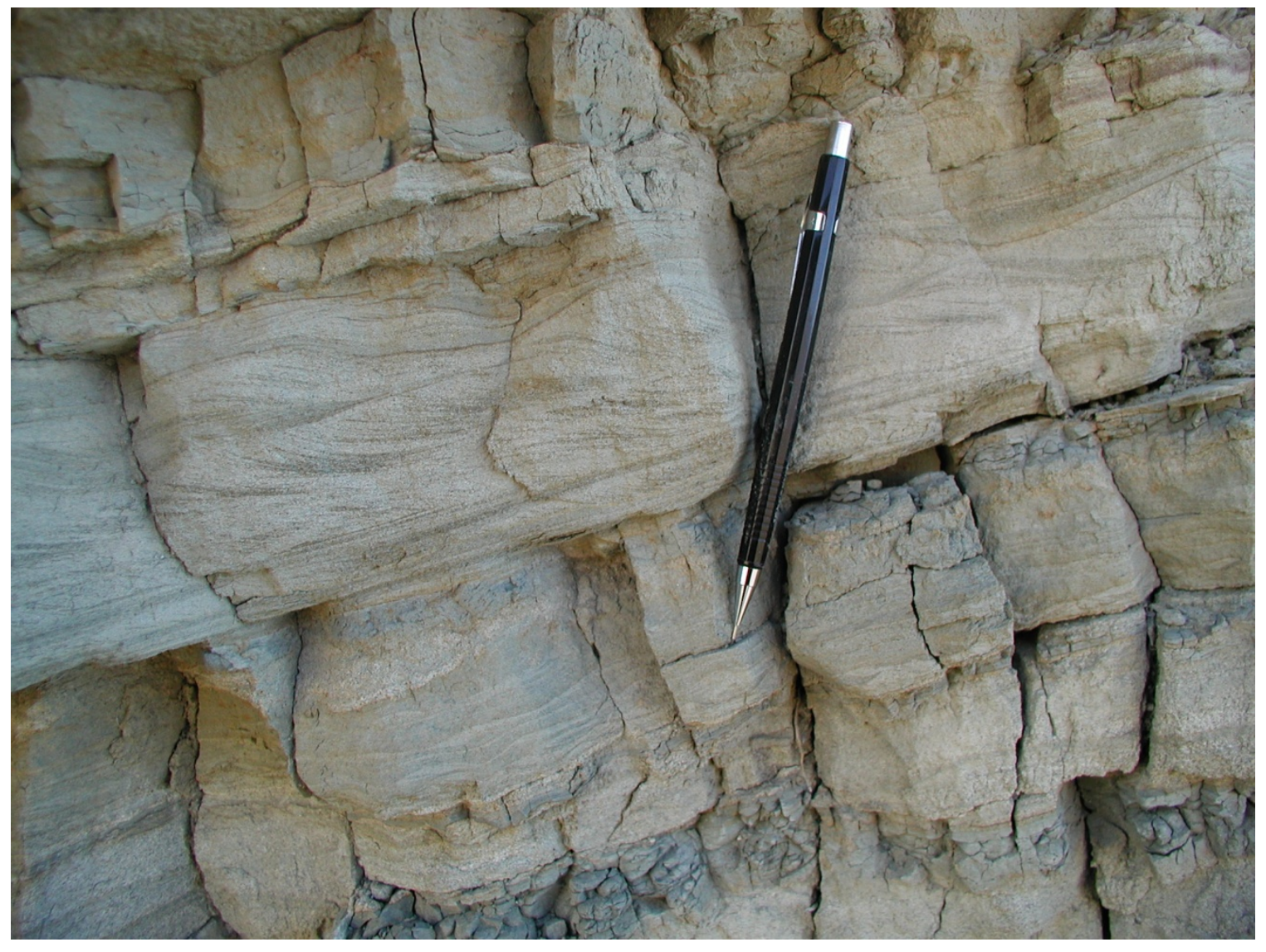

Figure 20. Lithologic details and sedimentary structures, ripple-laminated unit (Tstlr) of San Timoteo formation lower member; roadcut of Jackrabbit Trail. Location: El Casco 7.5' quadrangle, NW1/4 Sec. 23, T. 3 S., R. 2 W. (photo by D.M. Morton, 1999). Note (1) thin interbeds of chippy weathering greenish-gray mudrock and (2) climbingripple lamination in layer behind pencil. 


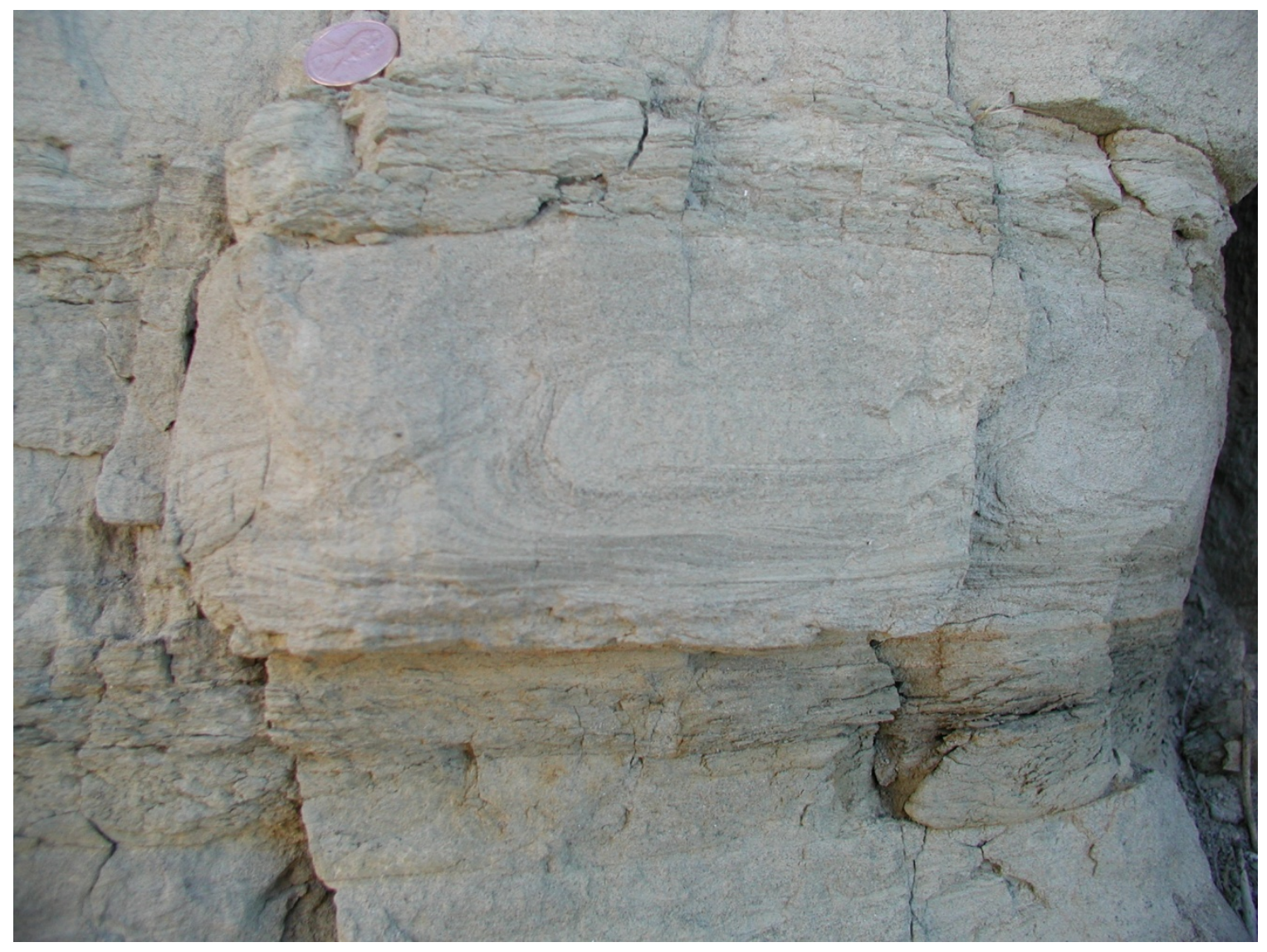

Figure 21. Lithologic and structural details, ripple-laminated member of the San Timoteo formation (unit Tstlr) in roadcut of Jackrabbit Trail. Location: El Casco 7.5' quadrangle, NW1/4 Sec. 23, T. 3 S., R. 2 W. (photo by D.M. Morton, 1999). Note (1) thin interbed of chippy weathering, flat-laminated, greenish-gray mudrock in lower part of photo and (2) pillow-and-ball structures with attendant flame structures in sandy layer above mudrock interbed; coin for scale at top of photograph. 


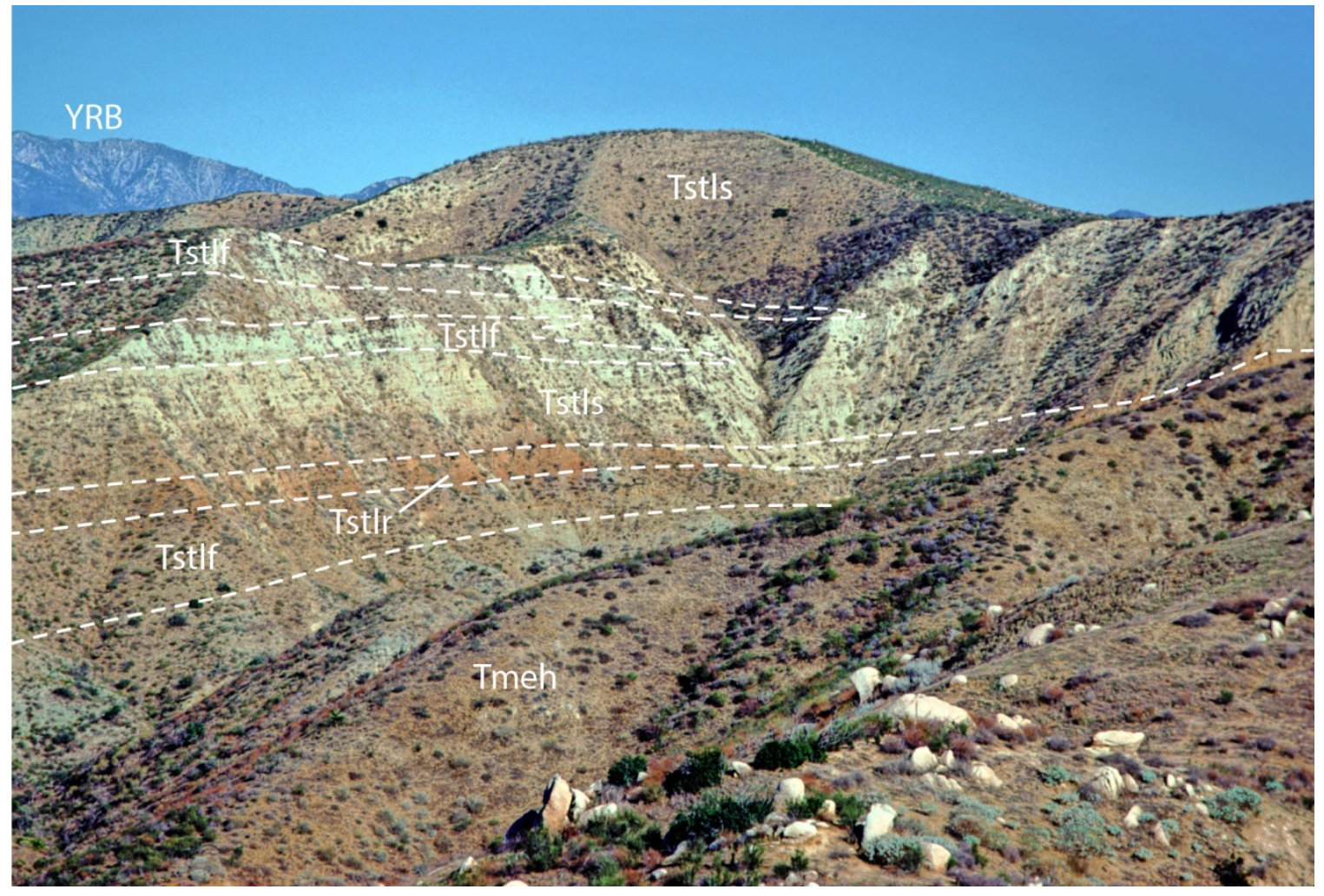

Figure 22. Boundary interval between the Mt. Eden formation of Frick (1921) (slope-forming unit in foreground) and the San Timoteo formation of Frick (1921) (more ledgy unit in middle ground) in vicinity of lower Lamb Canyon. Photograph looking east-northeast in Beaumont 7.5' quadrangle, south-central part of Sec. 28, T. 3 S., R. 1 W. (photo by J.C. Matti, 1974). Yucaipa Ridge block (YRB) of San Bernardino Mountains in left background. Boundary interval here includes fine-grained sandy and muddy rocks of heterogeneous member, Mt. Eden formation (unit Tmeh) overlain by fine-grained, ripple-laminated, and sandstone units (Tstlf, Tstlr, and Tstls) of San Timoteo formation, lower member. Here, greenish mudrock beneath ripple-laminated unit belongs to fine-grained unit (Tstlf) of the San Timoteo formation; these mudrocks are difficult to distinguish from those in underlying heterogeneous member of the Mt. Eden formation, and probably would be included in that unit were it not for stratigraphic relations in Laborde Canyon area a few miles to west (behind viewer); there, a mudrock unit directly beneath ripplelaminated unit clearly is part of the San Timoteo formation (see text). In Laborde Canyon, Mt. Eden interval consists exclusively of coarse-grained rock of arkosic and lithic member of the Mt. Eden formation, rather than greenish-gray mudrock and sandstone as in this photograph, so stratigraphic assignments there are more straightforward. Our sense is that boundary interval between the Mt. Eden and San Timoteo formations here in southeast part of San Timoteo Badlands is more transitional than in Mt. Eden area to west, with greenish mudrock of lacustrine origin occurring in both units as result of depositional conditions locally being similar across boundary interval. Note (1) tongues of fine-grained unit of lower San Timoteo member (Tstlf) pinching in and out of the sandy unit of member (Tstlf), (2) reddish-orange sandstone beds of ripple-laminated unit (Tstlr) (contrast with fig. 18), and (3) granitic boulders in foreground that are float from boulder conglomerate member of the Mt. Eden formation (unit Tmeb). In this vicinity, beds of the San Timoteo formation buttress nonconformably against and completely bury granitic Pliocene-Miocene inselberg (not visible) just behind rounded hill in middle ground. 


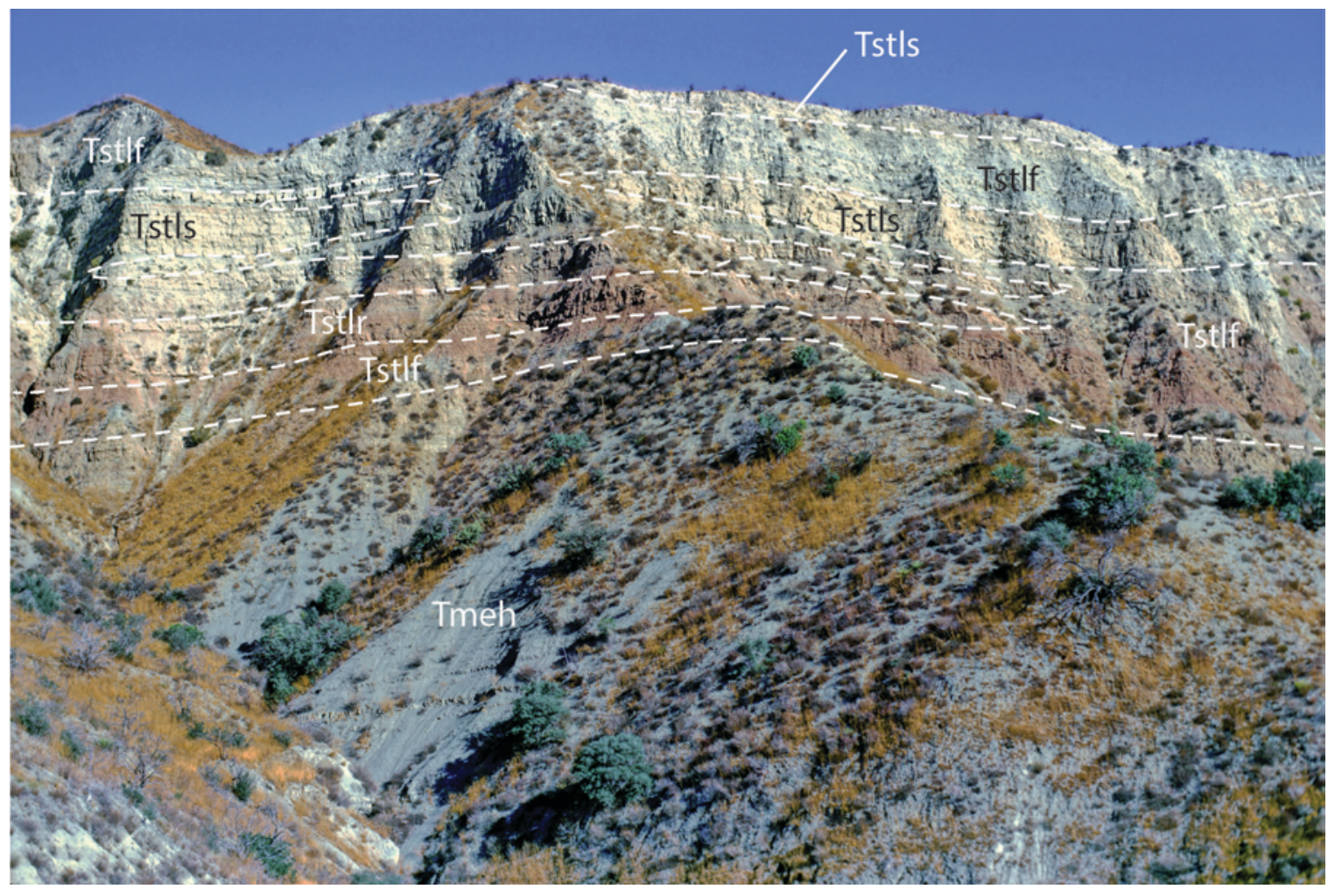

Figure 23. Boundary interval between the Mt. Eden formation of Frick (1921) (greenish-gray slopes in foreground) and the San Timoteo formation of Frick (1921) (ledgy rocks in upper part of outcrop) in vicinity of lower Lamb Canyon. Photograph looking northeast in San Jacinto 7.5' quadrangle, south-central part of Sec. 33, T. 3 S., R. 1 W. (photo by J.C. Matti, 1974). Boundary interval here is generally similar to that in figure 22 a few hundred meters north-northwest of this view, except here greenish mudrock is more abundant in heterogeneous member of the Mt. Eden formation (unit Tmeh), making it even more difficult to separate that unit from overlying fine-grained member of the San Timoteo formation (unit Tstlf); Tstlr and Tstls indicate ripple-laminated and sandstone units of lower member of the San Timoteo formation. This outcrop sequence reinforces our sense that, in southeast part of San Timoteo Badlands, boundary interval between the Mt. Eden and San Timoteo formations is more transitional than in Mt. Eden area to west, with greenish mudrock of lacustrine origin occurring in both units as result of depositional conditions locally being similar across boundary interval. Note (a) southeastward pinchout of ripple-laminated unit (unit Tstlr), (b) intertongueing of units TstIr, Tstlf, and Tstls, and (c) reddish color of sandstone beds of ripplelaminated unit (Tstlr) (contrast with fig. 18). 


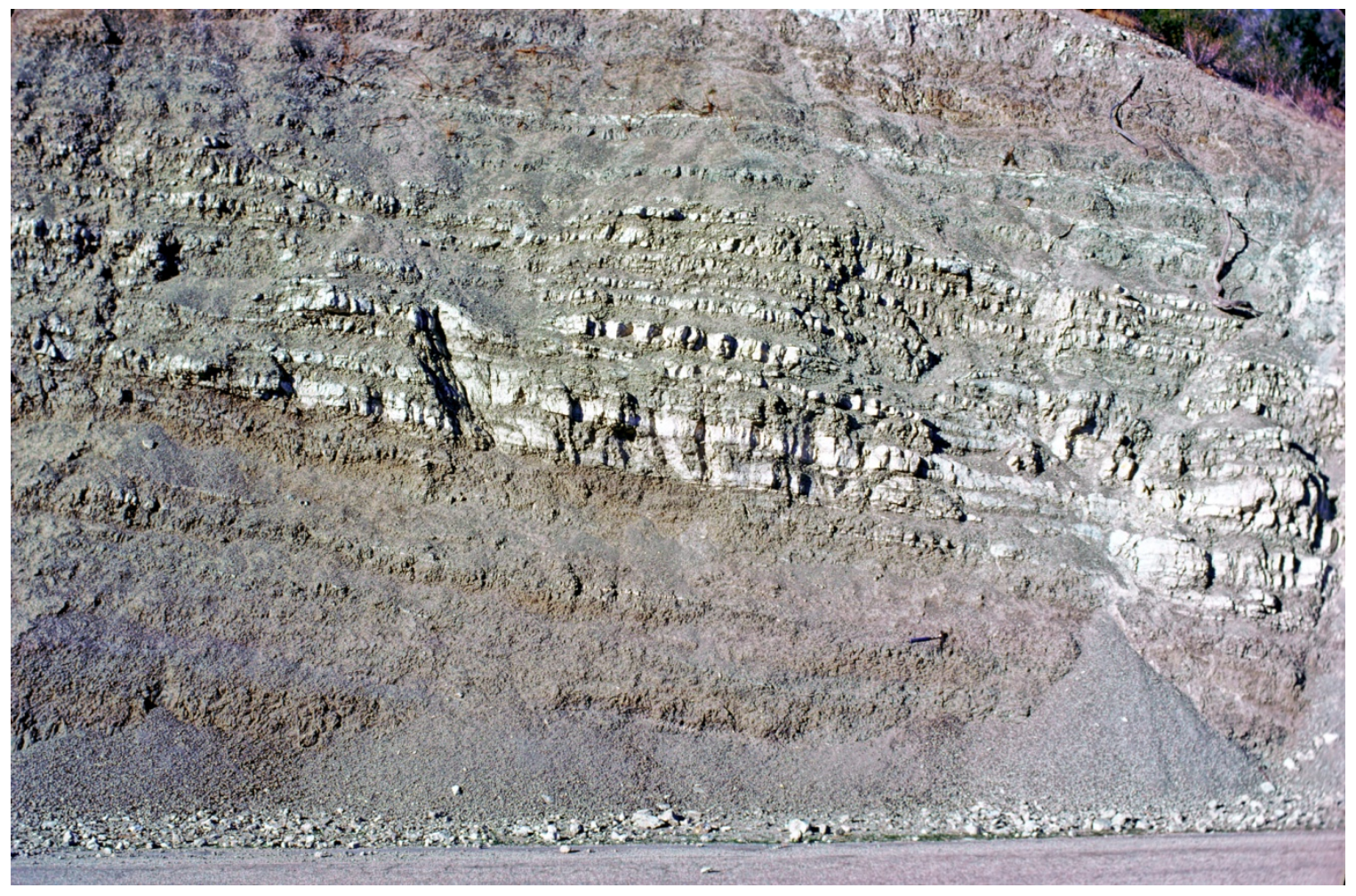

Figure 24. Heterogeneous member of the Mt. Eden formation (unit Tmeh) in roadcut of Jackrabbit Trail. View looking northwest in El Casco 7.5' quadrangle, NW11/4 Sec. 23, T. 3 S., R. 2 W. (photo J.C. Matti, 1974). Ledgeforming layers are white limestone ("limestone breccia" of Frick, 1921) and subordinate very fine sandstone; recessive layers are greenish-gray mudrock (mudstone, claystone, siltstone) and brownish fine sandy rock. 


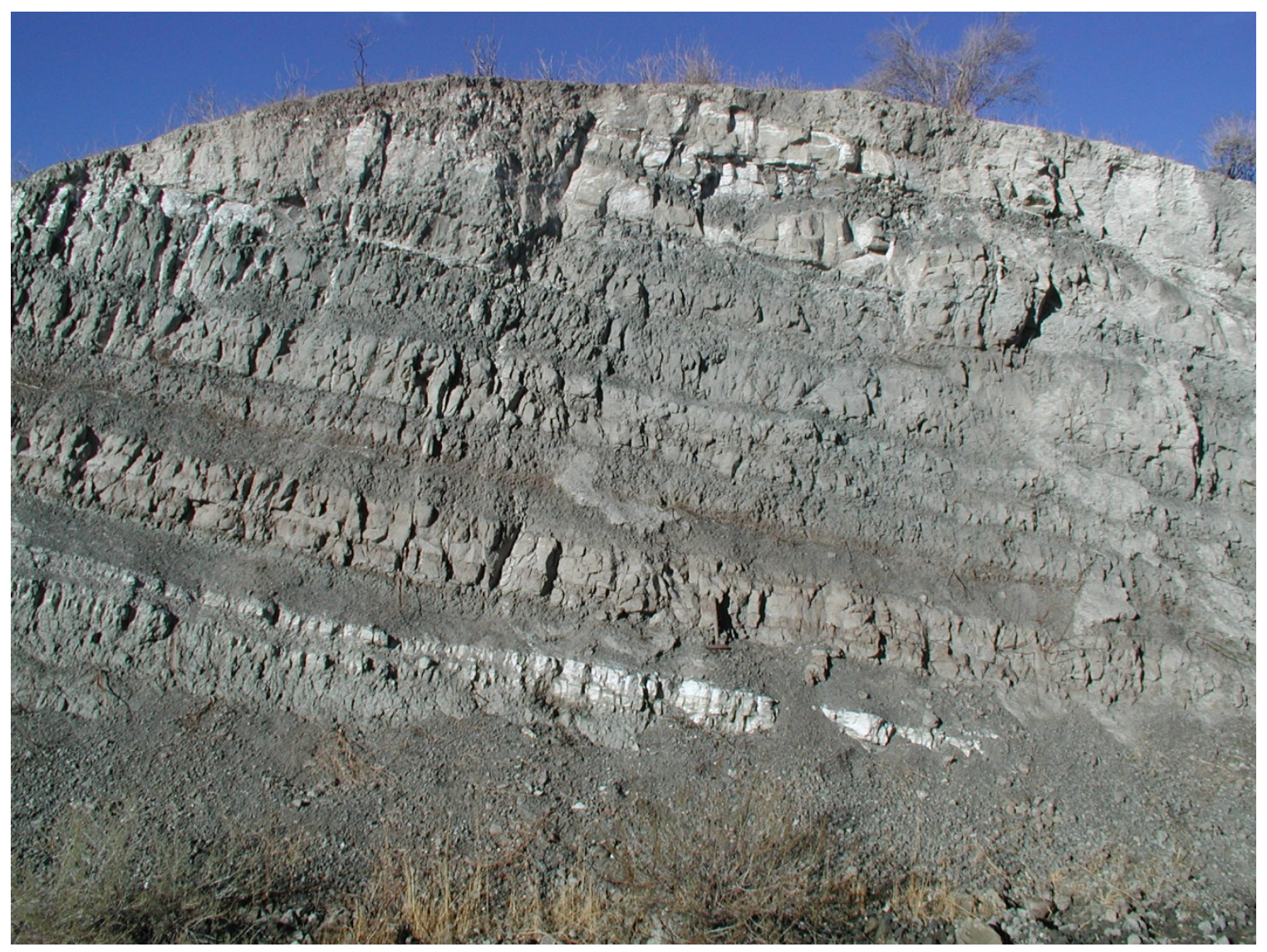

Figure 25. Heterogeneous member of the Mt. Eden formation (unit Tmeh) in roadcut of Jackrabbit Trail. View looking northwest in El Casco 7.5' quadrangle, NW1⁄1/4 Sec. 23, T. 3 S., R. 2 W. (photo by D.M. Morton, 1999). Heterogeneous lithologies include (1) ledge-forming thin and medium layers of greenish-gray to gray fine sandy rock, (2) subordinate recessive layers of chippy-weathering greenish-gray mudrock (mudstone, claystone, siltstone), and (3) single layer of white limestone. As heterogeneous unit here and in figure 24 is traced eastward to Eden Hot Springs area, amount of greenish-gray mudrock increases so that unit Tmeh is difficult to distinguish from overlying fine-grained member of the San Timoteo formation (unit Tstlf). See text for discussion of this problem. 

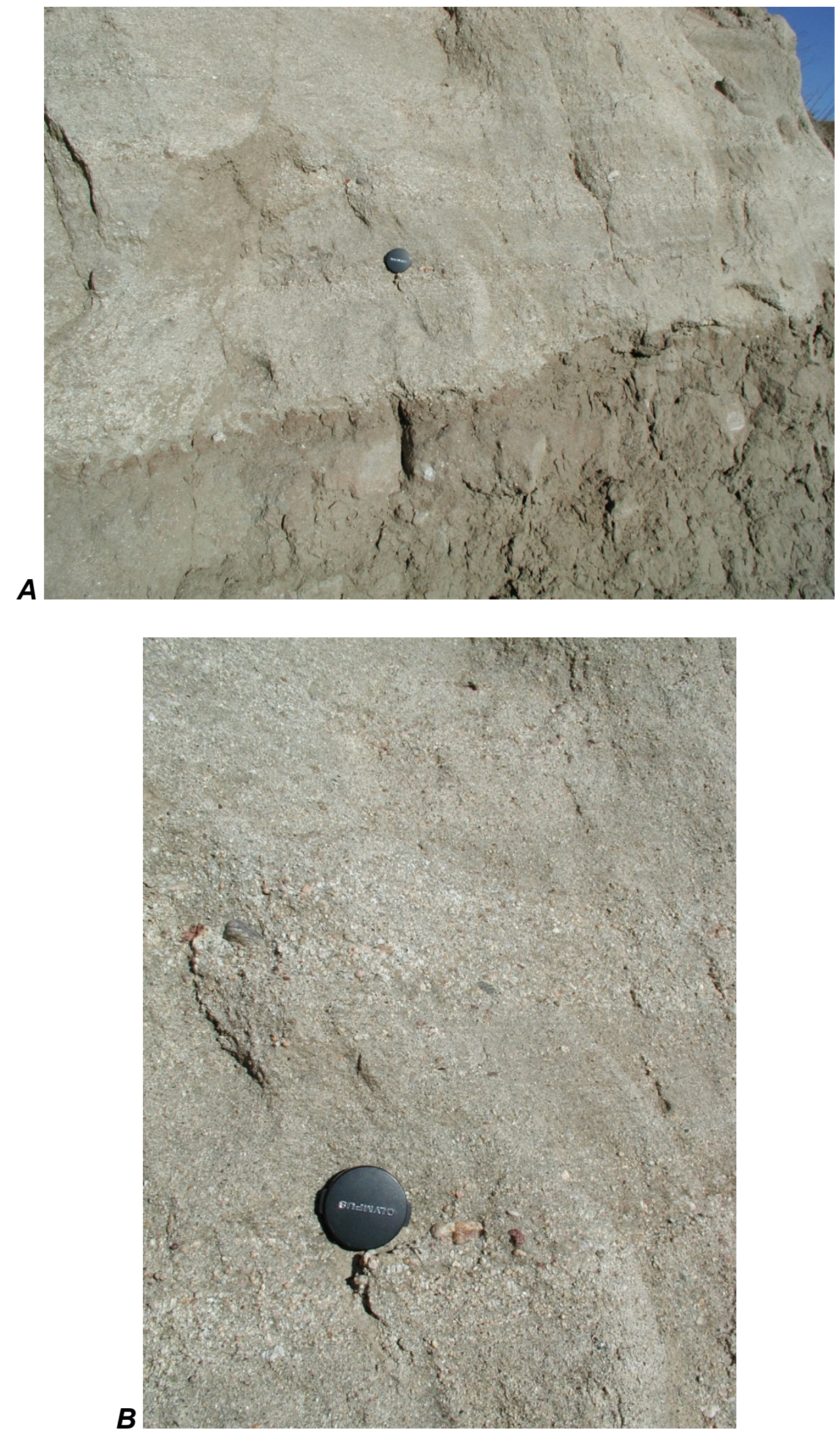

Figure 26. Heterogeneous member of the Mt. Eden formation (unit Tmeh) in roadcut of Jackrabbit Trail, close to boundary with underlying lithic and arkosic unit (Tmea); view looking north in El Casco 7.5' quadrangle, NW1/4 Sec. 23, T. 3 S., R. 2 W. (photos by D.M. Morton, 1999). A, Very pale-brown, crudely laminated to texturally massive 
Figure 26.-Continued

sandy conglomerate and conglomeratic sandstone containing granules and small pebbles of Peninsular Rangestype rock overly layer of brownish-gray mudrock; lens cap for scale. See close-up view in figure $26 \mathrm{~B}$. B, Close up of coarse sandy and conglomeratic layer shown in figure 26A. Note poor sorting, pinkish and white feldspathic and quartzofeldspathic grains and clasts, and dark-gray clasts of metasedimentary gneiss.

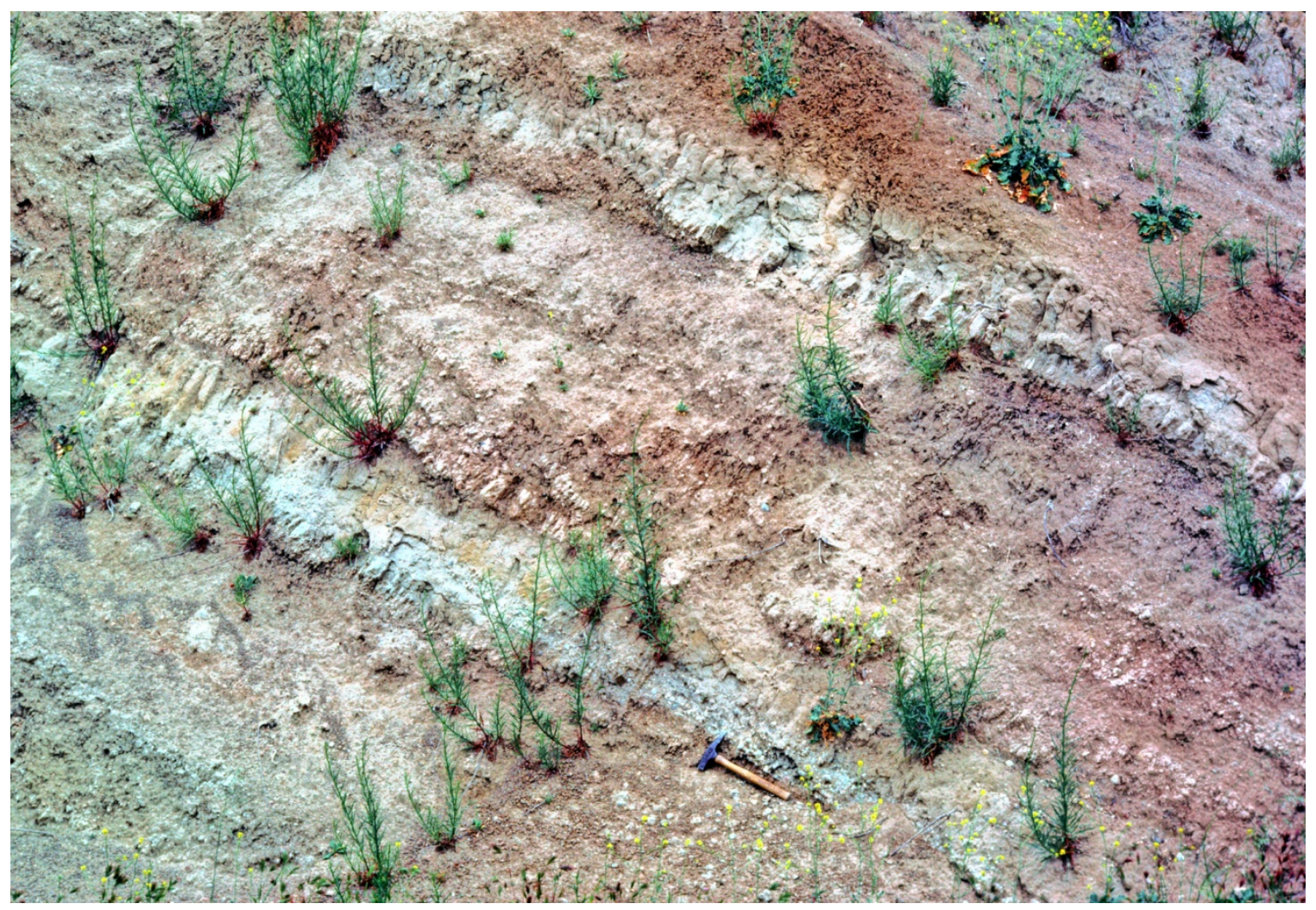

Figure 27. Arkosic and lithic member of the Mt. Eden formation (unit Tmea) along access road to Eden Hot Springs; view looking west in El Casco 7.5' quadrangle, south-central part of Sec. 23, T. 3 S., R. 2 W. (photo by J.C. Matti, 1974). Layers consist mainly of texturally massive to faintly laminated, feldspar-rich (arkosic) and lithic sandy rock; note greenish-gray mudrock interval above hammer head. 


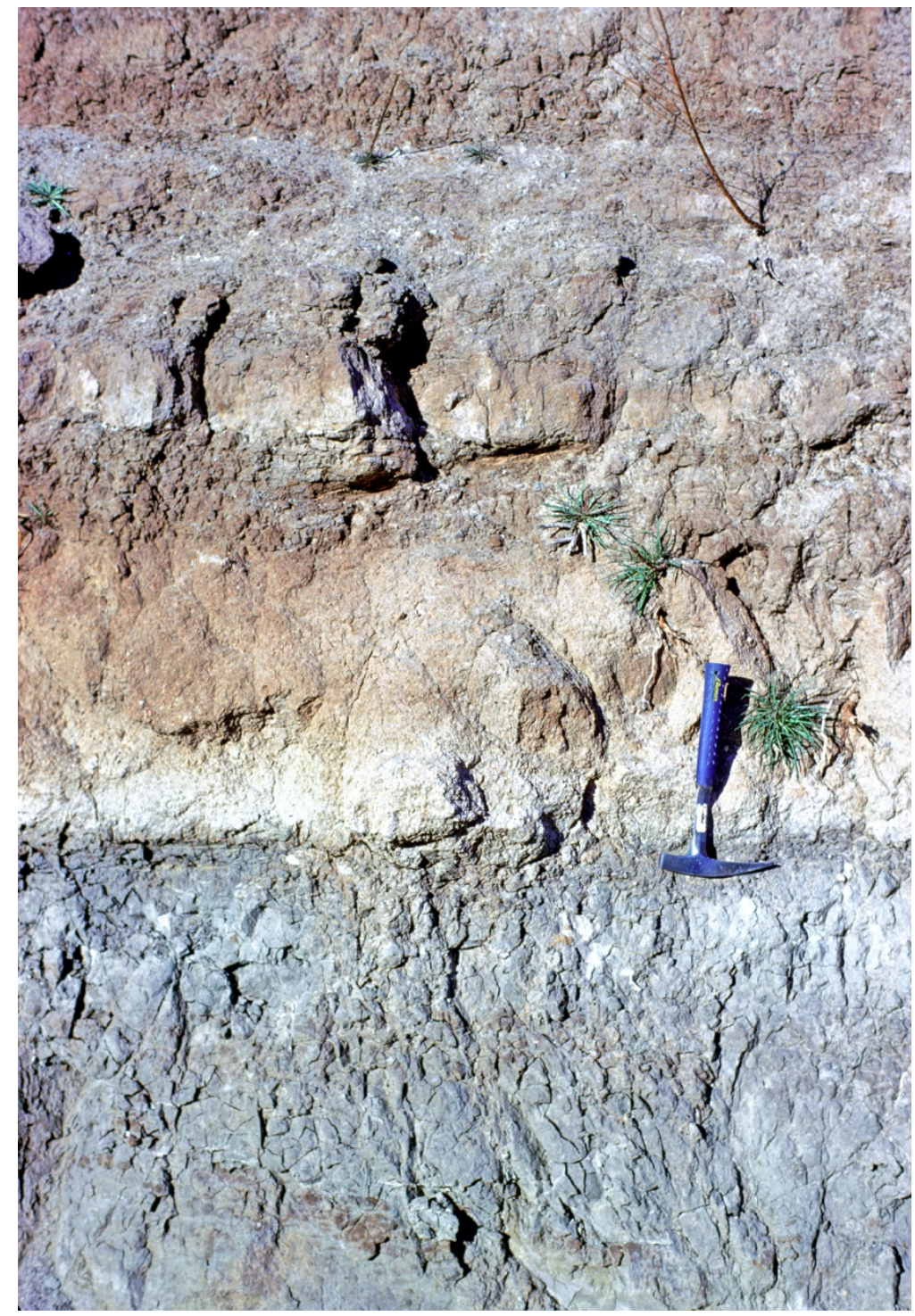

Figure 28. Arkosic and lithic member of the Mt. Eden formation (unit Tmea) along access road to Eden Hot Springs; view looking west in El Casco 7.5' quadrangle, south-central part of Sec. 23, T. 3 S., R. 2 W. (photo by J.C. Matti, 1974). Hammer head marks base of texturally massive to faintly laminated, feldspar-rich (arkosic) and lithic sandy rock underlain by gray to greenish-gray texturally massive mudrock and very fine sandstone. 


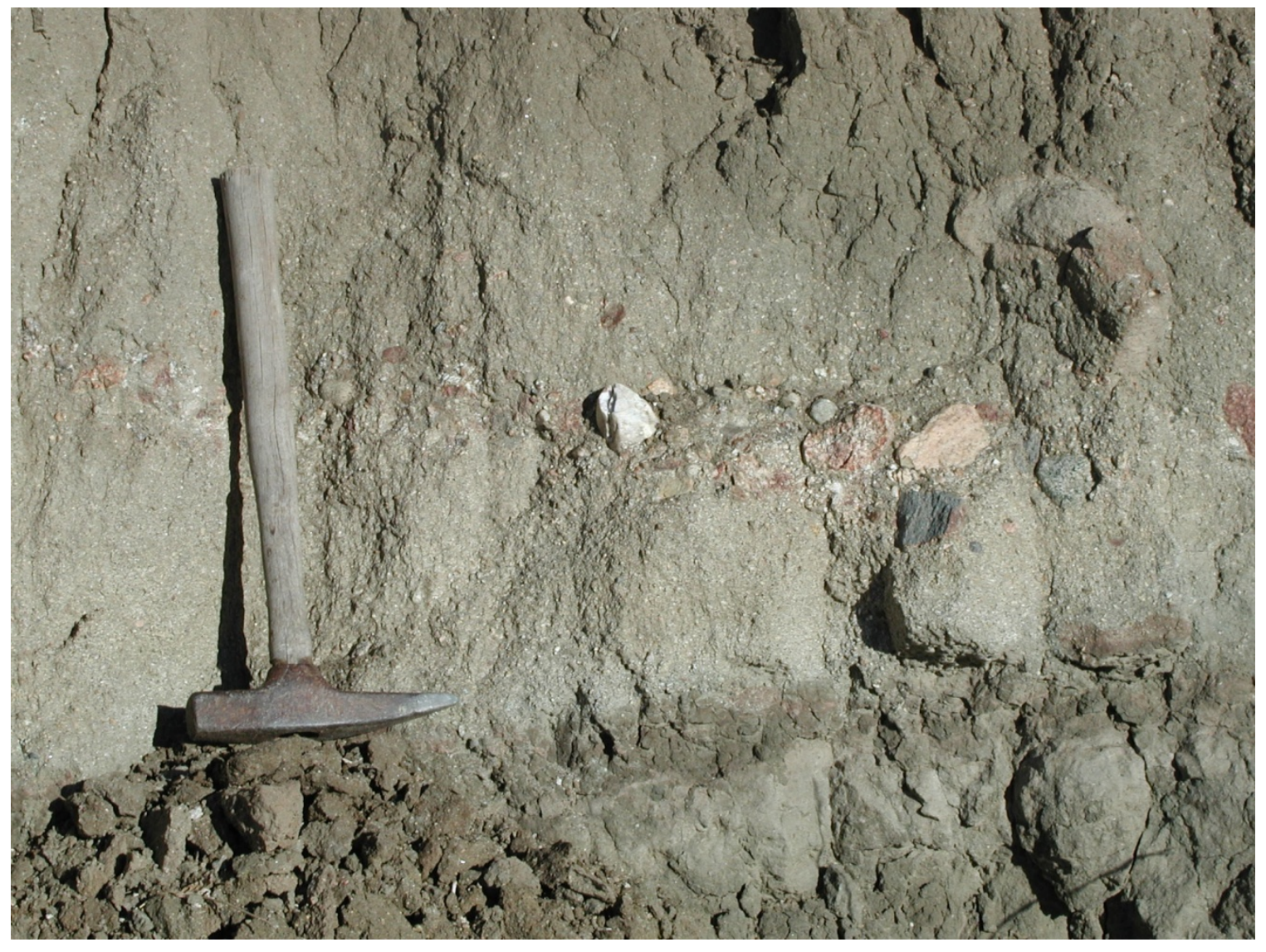

Figure 29. Details of arkosic and lithic member of the Mt. Eden formation (unit Tmea) in roadcut of Jackrabbit Trail; El Casco 7.5' quadrangle, south-central part of NW11/4 Sec. 23, T. 3 S., R. 2 W. (photo by D.M. Morton, 1999). Very pale-brown conglomeratic sandy rock and sandy conglomerate (behind hammer) abruptly overlies chippy weathering mudrock and sandy mudrock; note texturally massive fabric of coarse rock and mottled aspect of mudrock. Clasts in thin conglomeratic layer are pebble to small-cobble size, are angular to subangular, and exclusively are crystalline-rock fragments of Peninsular Ranges-type, including granitoids, marble, schist, and gneiss. 


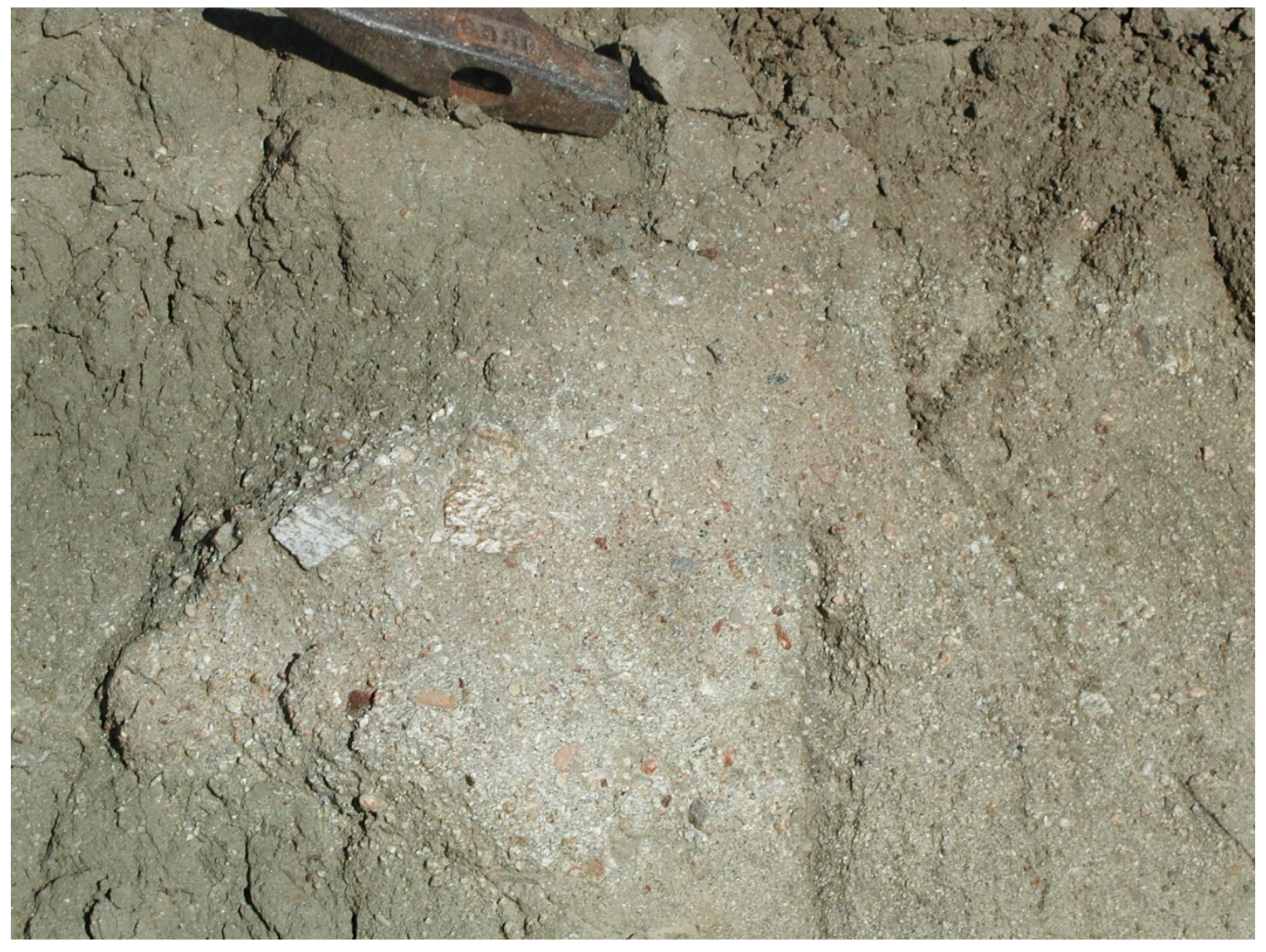

Figure 30. Details of arkosic and lithic member of the Mt. Eden formation (unit Tmea) in roadcut of Jackrabbit Trail; El Casco 7.5' quadrangle, south-central part of NW11/4 Sec. 23, T. 3 S., R. 2 W. (photo by D.M. Morton, 1999). Very pale-brown conglomeratic sandy rock and sandy conglomerate is crudely stratified and texturally massive, and is very poorly sorted. Clasts are pebble to small-cobble size, are angular to subrounded, and consist exclusively of Peninsular Ranges-type crystalline rock, here dominated by heterogeneous granitoids. Sediment probably fluvial in origin, although more massive textures could reflect colluvial deposition. 


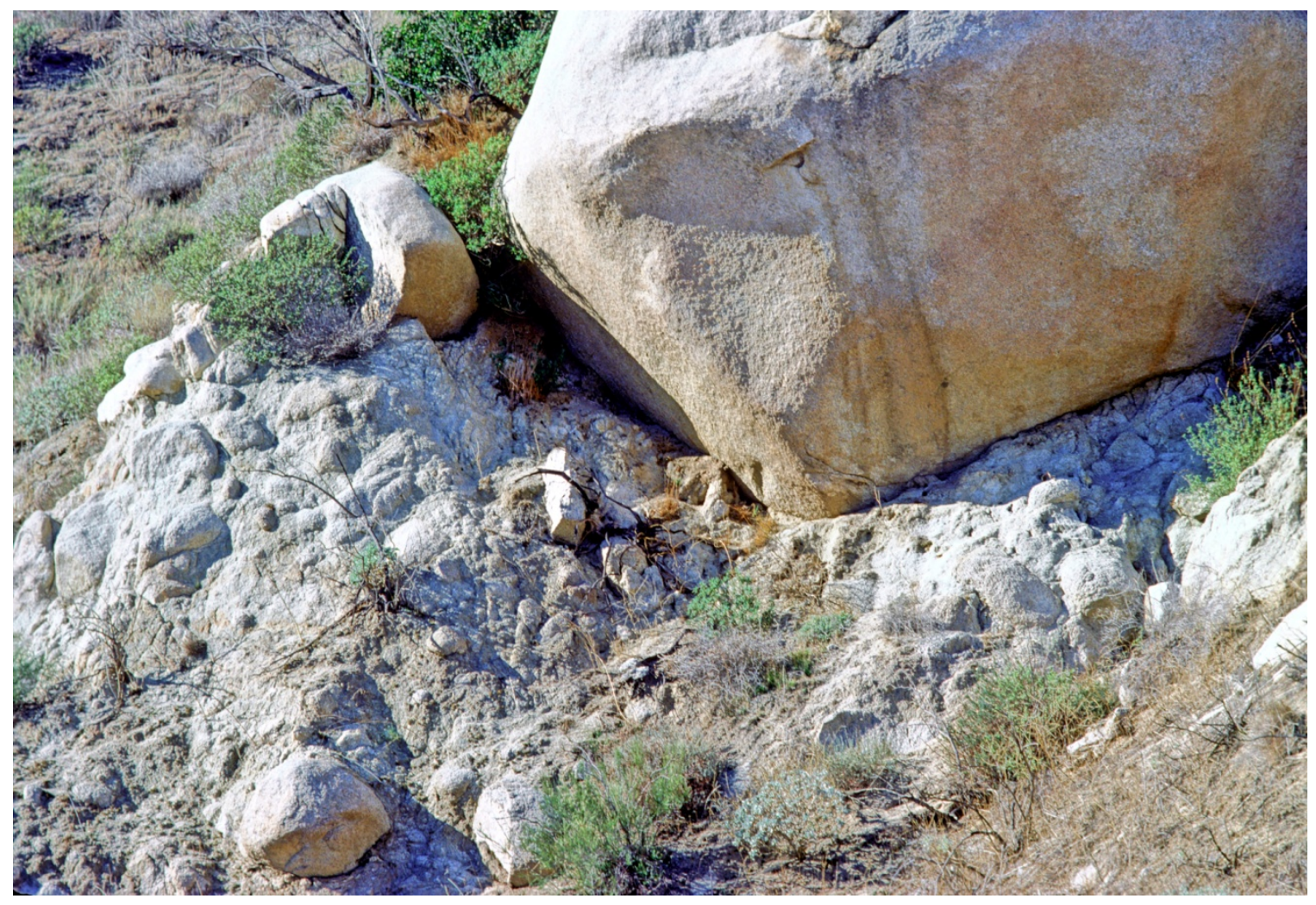

Figure 31. Boulder conglomerate member of the Mt. Eden formation (unit Tmeb) in lower Lamb Canyon; view looking northeast in Lakeview 7.5' quadrangle, south-central part of Sec. 32, T. 3 S., R. 1 W. (photo by J.C. Matti, 1974). Note texturally massive fabric and extremely poor sorting, with particles ranging from sand- to boulder-size; large boulder is about $6 \mathrm{~m}$ in dimension; clasts exclusively are tonalite similar to tonalite of Lamb Canyon (unit Ktlc). Materials in unit Tmeb originated as mass-wasting deposit (debris flow and [or] rock avalanche) shed southward from Ktlc when that unit was exposed as inselberg a few miles north (to right) of this location. 


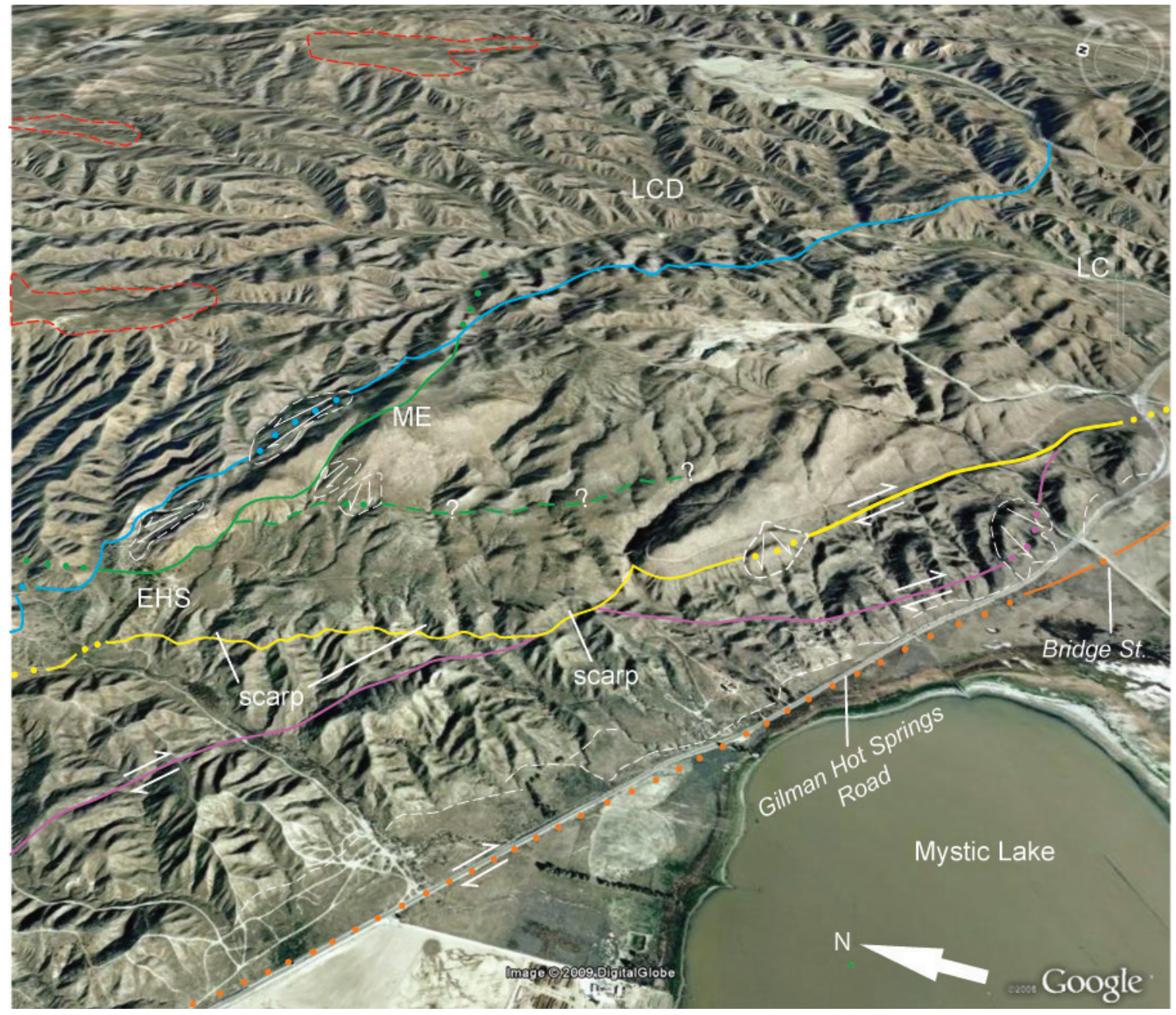

Figure 32. Google Earth ${ }^{\odot}$ image looking east-northeast toward Mt. Eden massif (ME), showing various faults we map in Mt. Eden area; San Jacinto Valley and Gilman Hot Springs Road in foreground along with Mystic Lakeephemeral lake that forms periodically in subsiding part of valley due to ponding of San Jacinto River (see Morton, 1977). EHS, Eden Hot Springs (ruins); LC, Laborde Canyon; LCD, Laborde Canyon drainage basin. Faults include: orange, San Jacinto Fault, Claremont strand; magenta, San Jacinto Fault, Moreno Valley strand; yellow, Mt. Eden Fault; green, Eden Hot Springs Fault; blue, Laborde Canyon Fault. White dashed lines encircle landslides bodies; arrows indicate downslope movement. White dashed lines along Gilman Hot Springs Road designate crown scarps of low-angle slope-movements (lateral spreads); red dashed lines, margins of San Timoteo erosion surface. Note scarp formed by Mt. Eden Fault, and gentle alluviated surfaces between scarp and Mt. Eden massif. Image used with permission. 


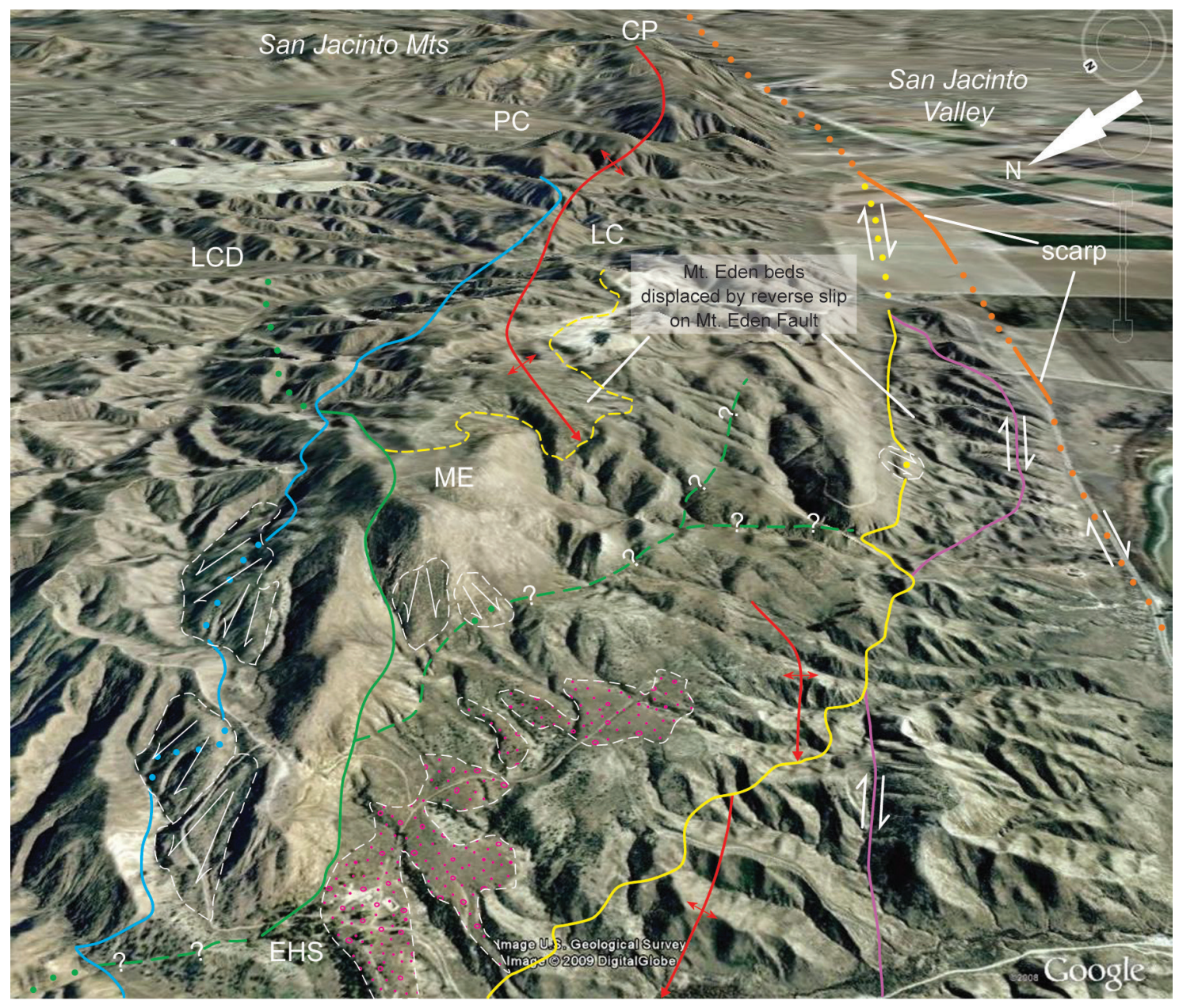

Figure 33. Google Earth ${ }^{\odot}$ image looking southeast toward Mt. Eden massif (ME), showing various faults we map in Mt. Eden area; San Jacinto Valley in right background. CP, Claremont Peak; EHS, Eden Hot Springs; LC, Laborde Canyon; LCD, Laborde Canyon drainage basin; PC, Potrero Canyon. Faults include: orange, San Jacinto Fault, Claremont strand; magenta, San Jacinto Fault, Moreno Valley strand; yellow, Mt. Eden Fault; green, Eden Hot Springs Fault; blue, Laborde Canyon Fault. White dashed lines denote landslides bodies (arrows indicate downslope movement). Yellow short-dashed line atop Mt. Eden massif denotes basal contact of Mt. Eden formation (arkosic and lithic member, Tmea) displaced from equivalent beds at southwest base of massif on opposite side of Mt. Eden Fault. Red solid line identifies position of crest of San Timoteo Anticline, plunging toward viewer; note how hinge line is displaced by Eden Hot Springs and Mt. Eden Faults. Also note scarp formed by Mt. Eden Fault, and alluviated gentle surfaces (red-dot pattern) between scarp and Mt. Eden massif. Image used with permission. 


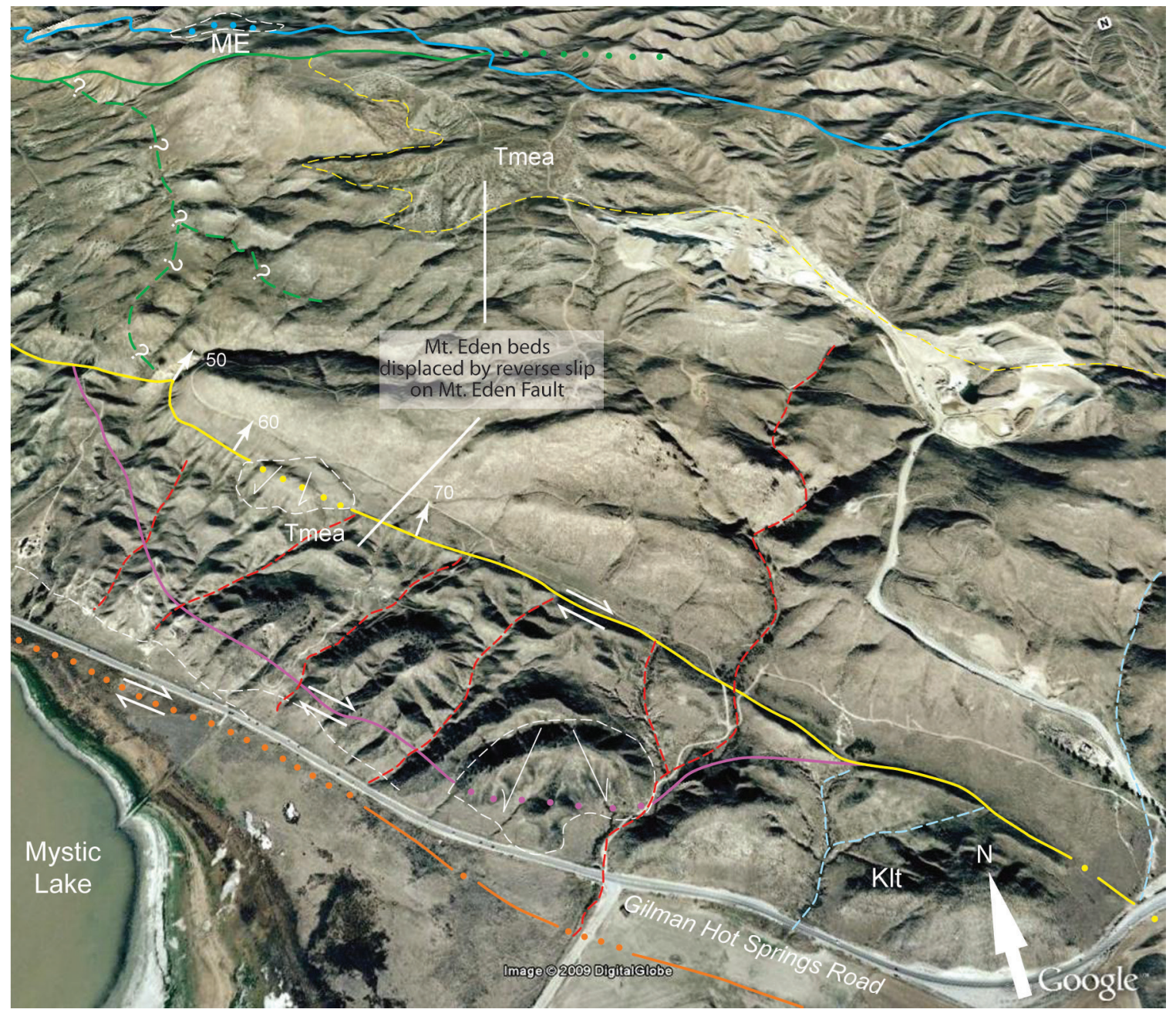

Figure 34. Google Earth ${ }^{\odot}$ image looking north toward Mt. Eden massif (ME), showing faults we map in Mt. Eden area; Mystic Lake is in left foreground. KIt, tonalite of Lakeview Mountains as mapped by Morton and Matti (2001a). Faults include: orange, San Jacinto Fault, Claremont strand; magenta, San Jacinto Fault, Moreno Valley strand; yellow, Mt. Eden Fault; green, Eden Hot Springs Fault; blue, Laborde Canyon Fault. White dashed lines delineate landslides bodies (arrows indicate movement direction). Yellow short-dashed line atop Mt. Eden massif denotes basal contact of Mt. Eden formation (arkosic and lithic member, Tmea) displaced from equivalent beds at southwest base of massif on opposite side of Mt. Eden Fault. Note drainages (short-dashed red lines) incised into block between Claremont strand and Mt. Eden Fault; these were eroded by streamflows down canyon left of road and displaced lateral by right-slip on Mt. Eden Fault. Image used with permission. 


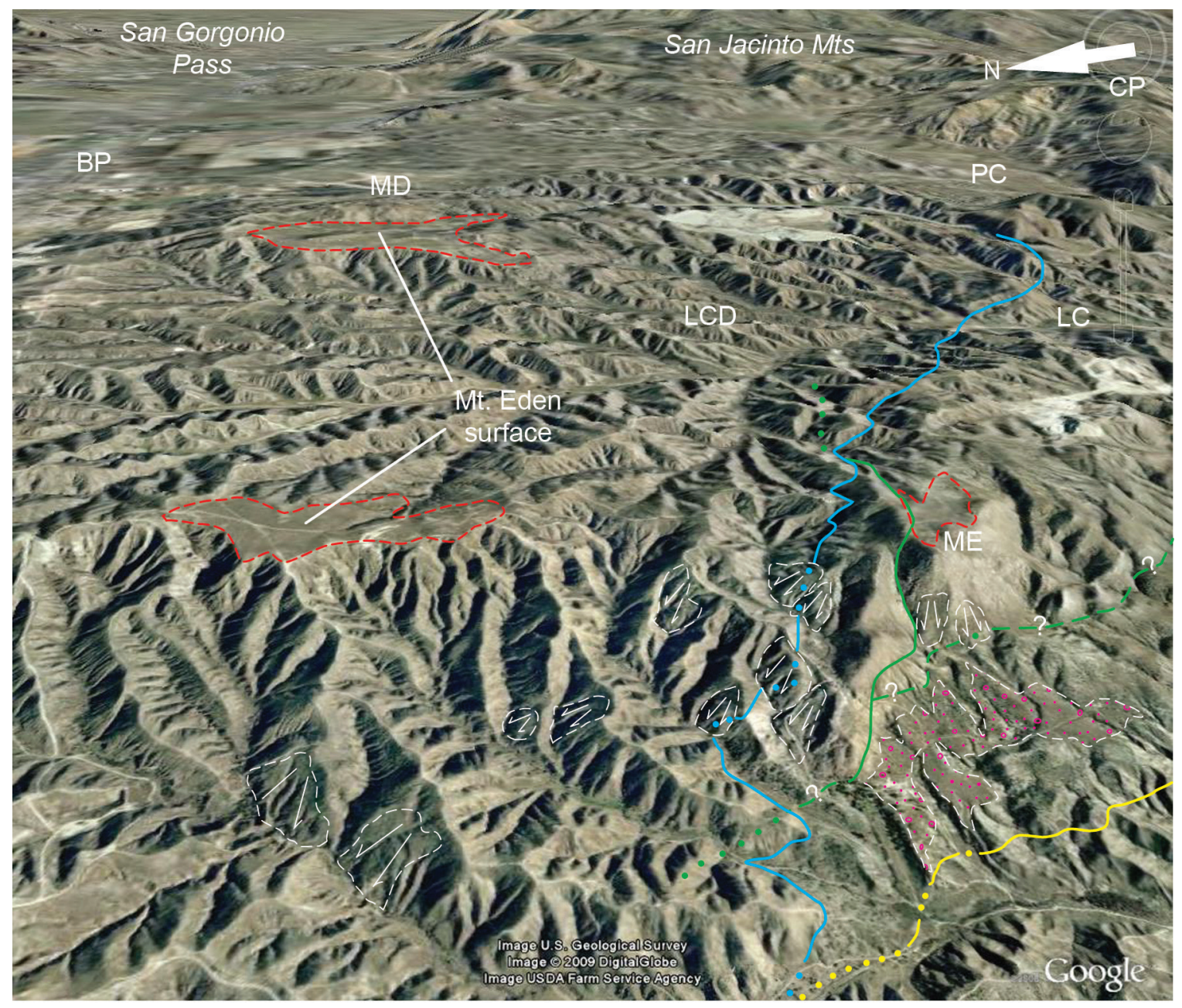

Figure 35. Google Earth ${ }^{\odot}$ image looking east-southeast toward Mt. Eden massif (ME), showing Mt. Eden surface (red short-dashed line) and faults we map in Mt. Eden area; San Gorgonio Pass in left background, San Jacinto Mountains in right background. BP, Beaumont Plain as used by Young and others (1941); LC, Laborde Canyon; LCD, Laborde Canyon drainage basin; MD, Mt. Davis in Beaumont 7.5' quadrangle; PC, Potrero Canyon. Faults include: yellow, Mt. Eden Fault; green, Eden Hot Springs Fault; blue, Laborde Canyon Fault. White dashed lines encircle landslide bodies (arrows indicate movement direction). We agree with English (1953) that Mt. Eden surface developed on sedimentary rocks north of Mt. Eden has been dropped down from correlative surface atop Mt. Eden massif, in this case by down-to-north normal-slip on Laborde Canyon Fault. Note scarp formed by Mt. Eden Fault (yellow), and alluviated gentle surfaces (red-dot pattern) between scarp and Mt. Eden massif. Image used with permission. 


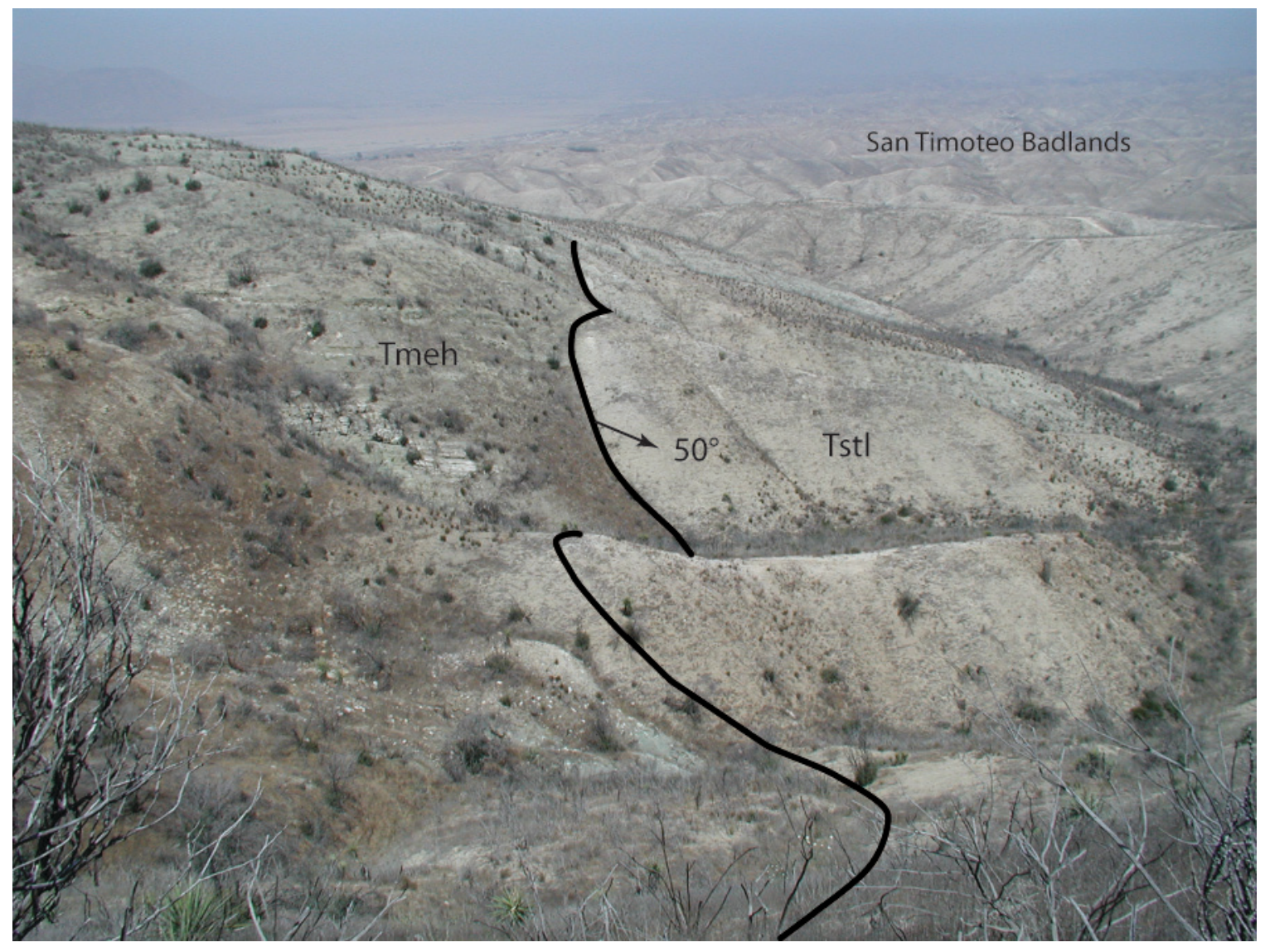

Figure 36. View looking northwest at Laborde Canyon Fault on north slope of Mt. Eden (photo by J.C. Matti, 6/2002); view looking northwest from near elevation 2254 in El Casco quadrangle, south-central part of Sec. 24, T. 3 S., R. 2.W.). Fault (black line) dips north about $50^{\circ}$, and separates light-colored strata of San Timoteo formation (lower member, sandstone unit Tstls) from dark-colored beds of Mt. Eden formation (heterogeneous member, unit Tmeh). Many of latest Miocene vertebrate fossils collected by Frick (1921) are from pits in smooth grayish-green slopes that form upper part of heterogeneous member of the Mt. Eden formation. See figure 37 for closer view of faulted stratigraphy. 


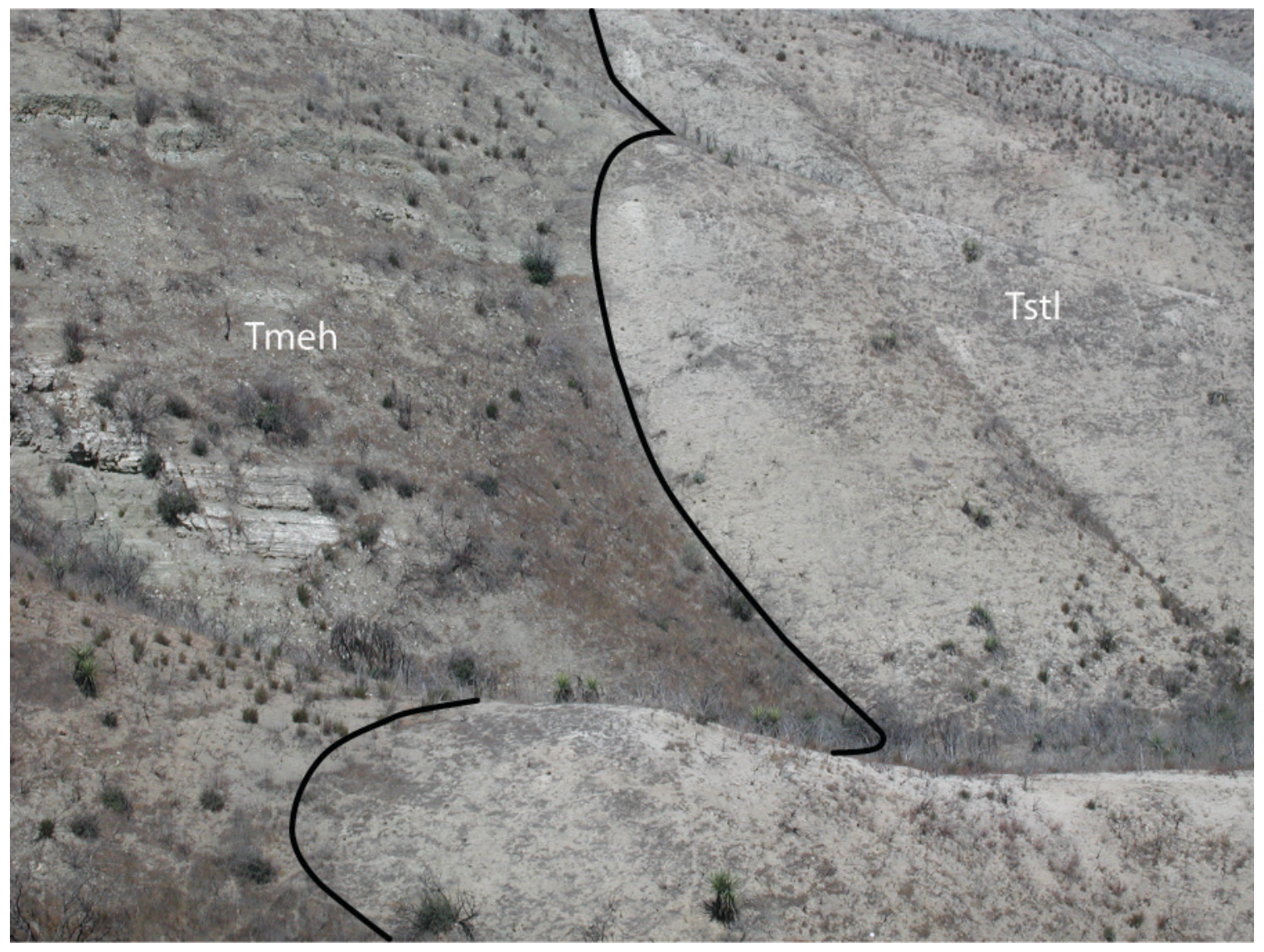

Figure 37. Close-up view of Laborde Canyon Fault shown in figure 36 (photo by J.C. Matti, 6/2002). Prominent beds above and below Tmeh label are very hard ledge-forming lithic and arkosic sandy rock that we have not observed anywhere else in heterogeneous member, thus testifying to its lithologic variability spatially. 


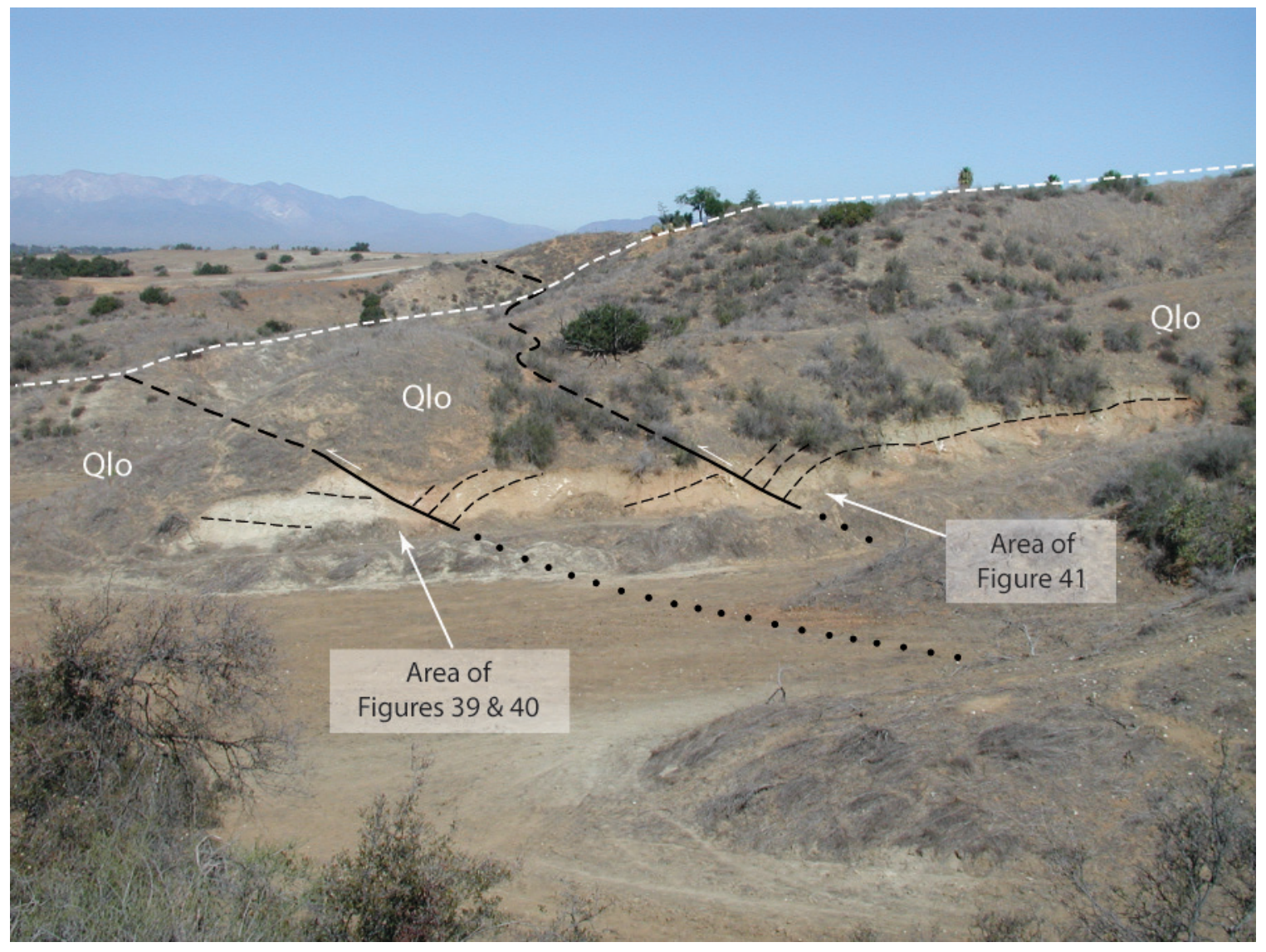

Figure 38. View of Cherry Valley Fault, showing topographic scarp and trench excavated by Petra Consultants (2004) (photograph by J.C. Matti, 11/2007); El Casco quadrangle, SW1/4 Sec. 14, T. 2 S., R. 2.W., view looking NW at SE-facing trench wall about $200 \mathrm{~m}$ from photo location on unpaved road; San Gabriel Mountains in far distance. Dashed white line delineates topographic profile of fault scarp, which is not well developed on ridge that has been excavated. Footwall consists mainly of the sedimentary deposits of Live Oak Canyon (Qlo) and older alluvial units. Hanging wall consists of Live Oak Canyon beds, here capped by residual pedogenic soil of unit Qvors. Some trench exposures in this area display local unconformities within Live Oak Canyon interval, which may record episodic tectonic activity on faults. Heavy black lines indicate two discrete fault traces; black thin-dashed lines depict folded layering in sedimentary deposits. See figures 39,40 , and 41 for closer views. 


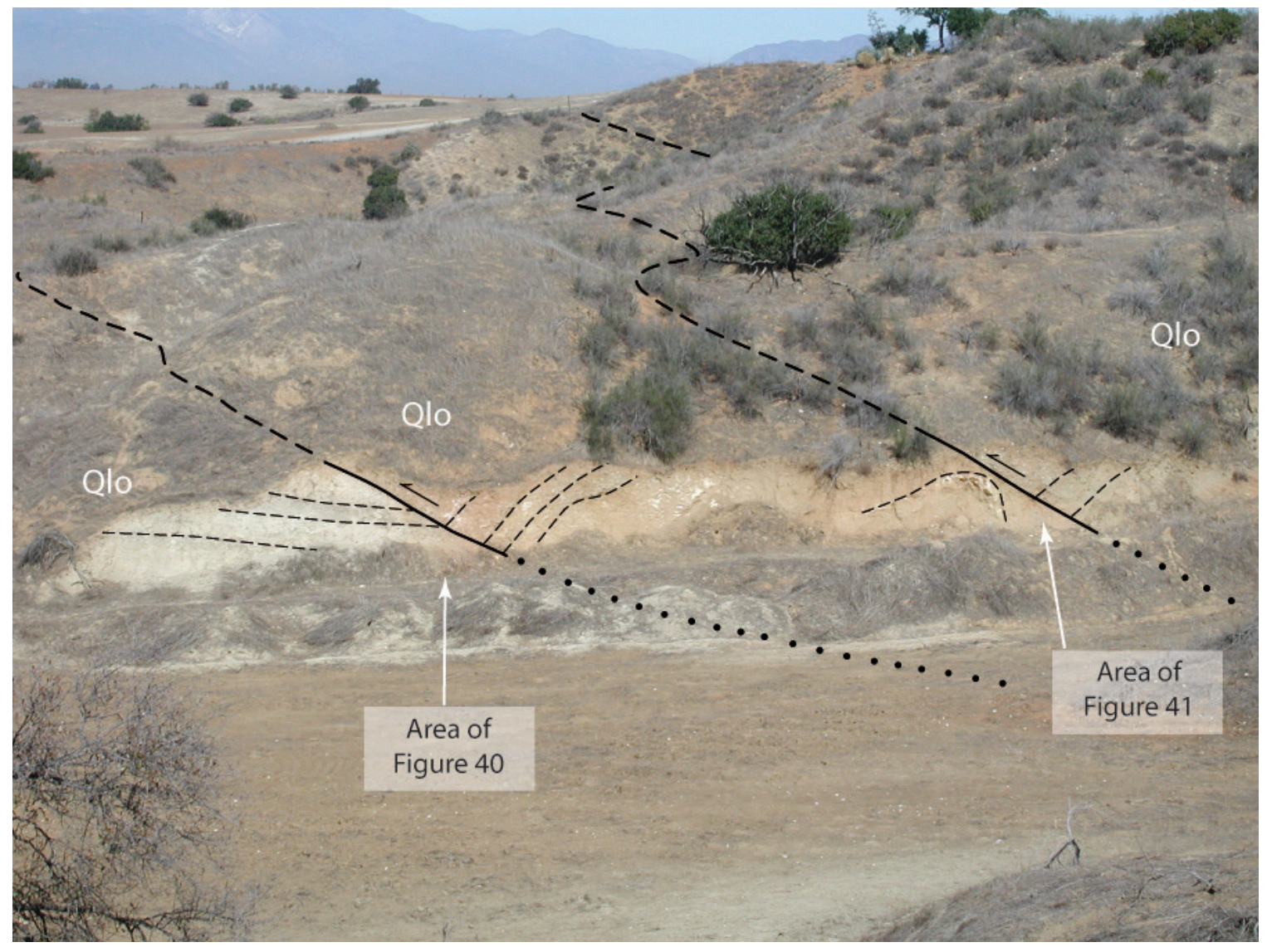

Figure 39. Closer view of trench exposures of figure 38 (see fig. 38 caption for location information; photograph by J.C. Matti, 11/2007). Note two north-dipping fault surfaces (heavy black lines and dots). Thin black short-dashed lines depict sedimentary layering. 


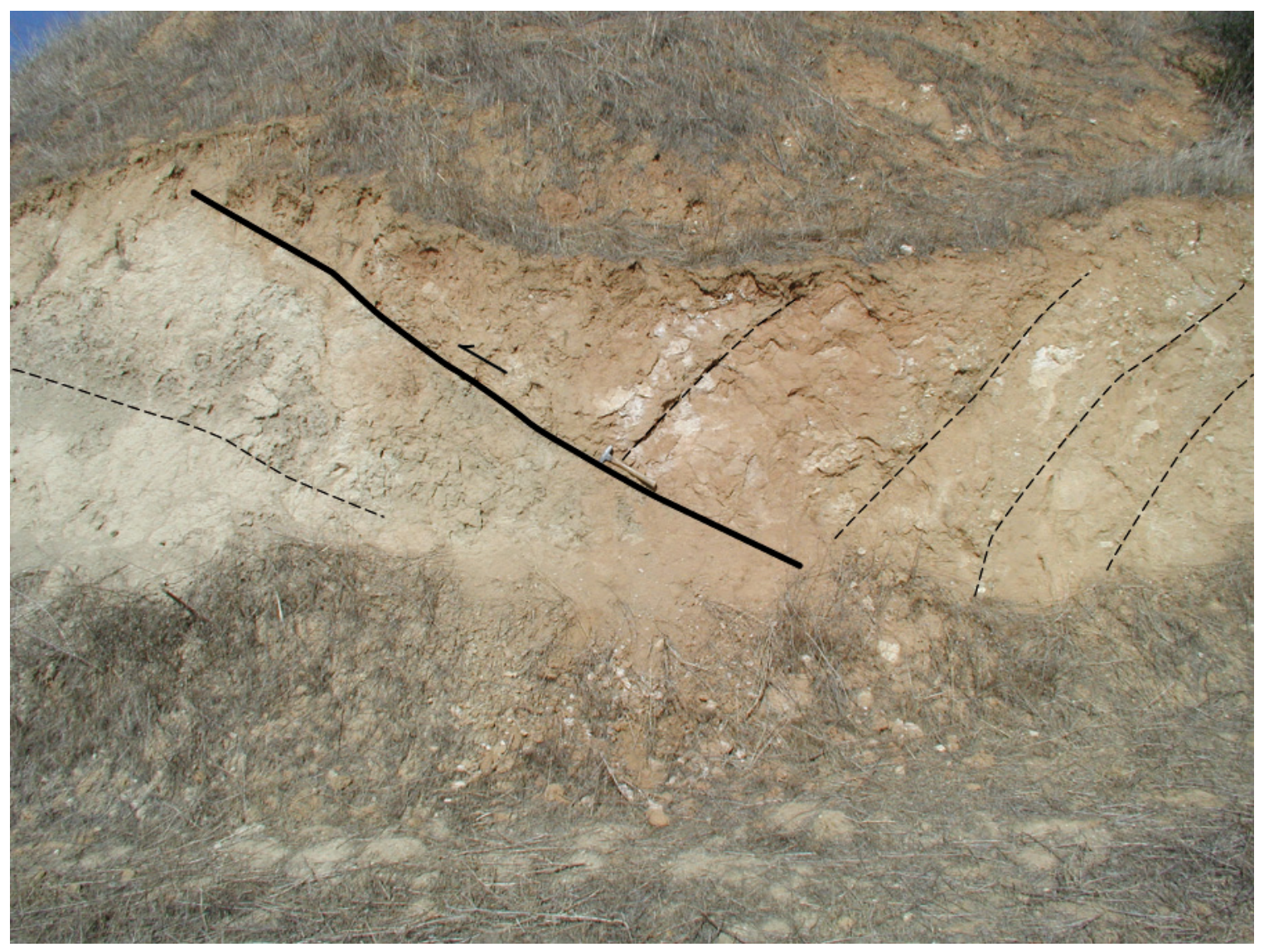

Figure 40. Closer view of trench exposures in figures 38 and 39 (see fig. 38 caption for location information; photograph by J.C. Matti, 11/2007). Discrete fault surface (heavy black line) is southern of two faults in figures 38 and 39. Sedimentary layering (black short-dashed lines) in brownish-colored hanging wall strata (right) has been tilted moderately south (left) into fault plane; they represent south limb of local anticlinal fold developed due to drag along fault surface as hanging wall moved over footwall. Footwall consists of light-colored fine-grained rock of the sedimentary deposits of Live Oak Canyon (Qlo). 


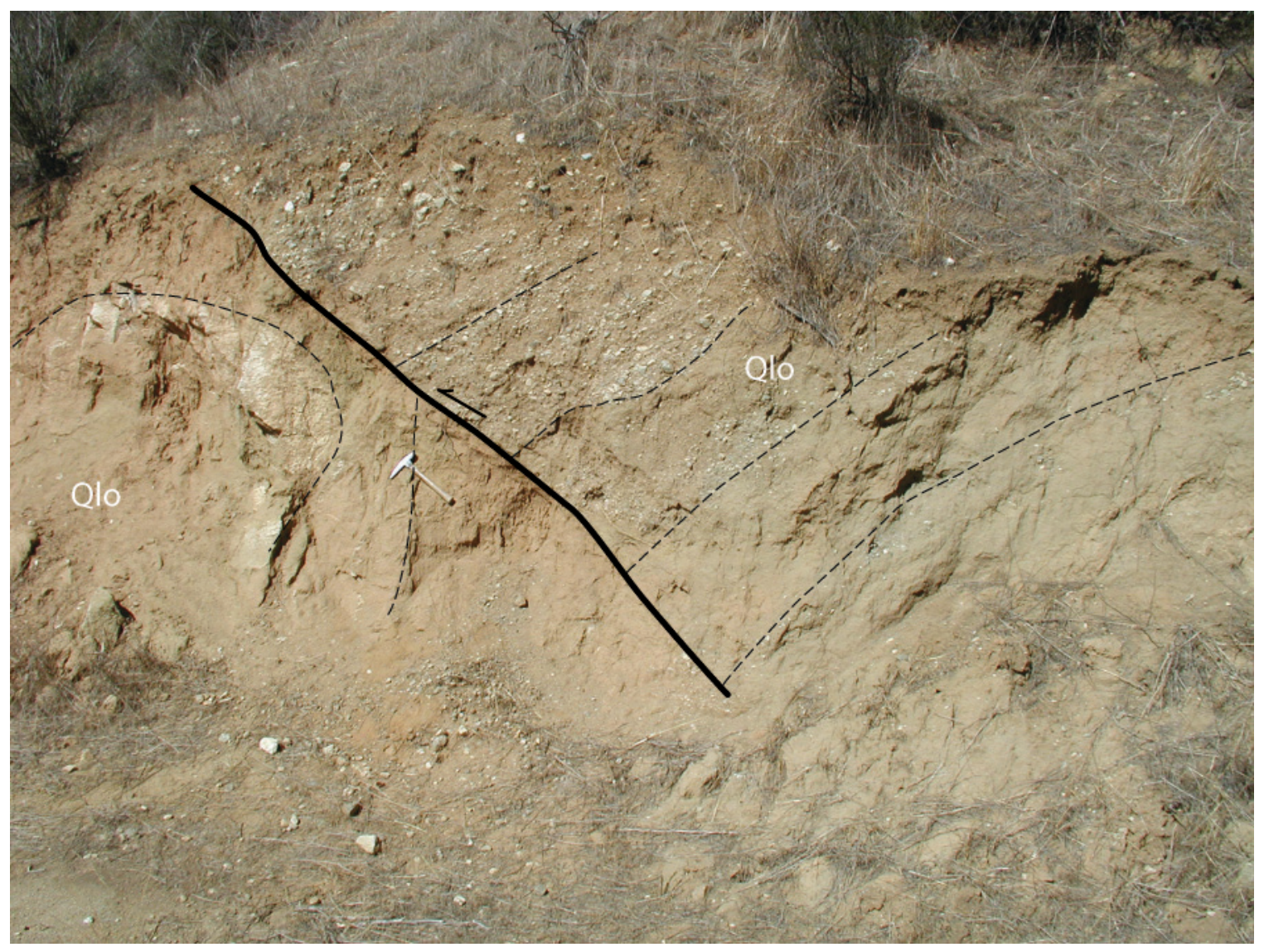

Figure 41. Closer view of trench exposures of figures 38 and 39 (see fig. 38 caption for location information; photograph by J.C. Matti, 11/2007). Discrete fault surface (heavy black line) is northern of two faults in figures 38 and 39. Strata in both footwall (left of fault) and hanging wall (right of fault) show effects of drag along fault surface: reddish-brown and white strata in footwall have been warped into anticlinal fold, light-brown strata in hanging wall have been warped downward to fault plane dip moderately south (left); on both blocks, black short-dashed lines depict bedding surfaces. 


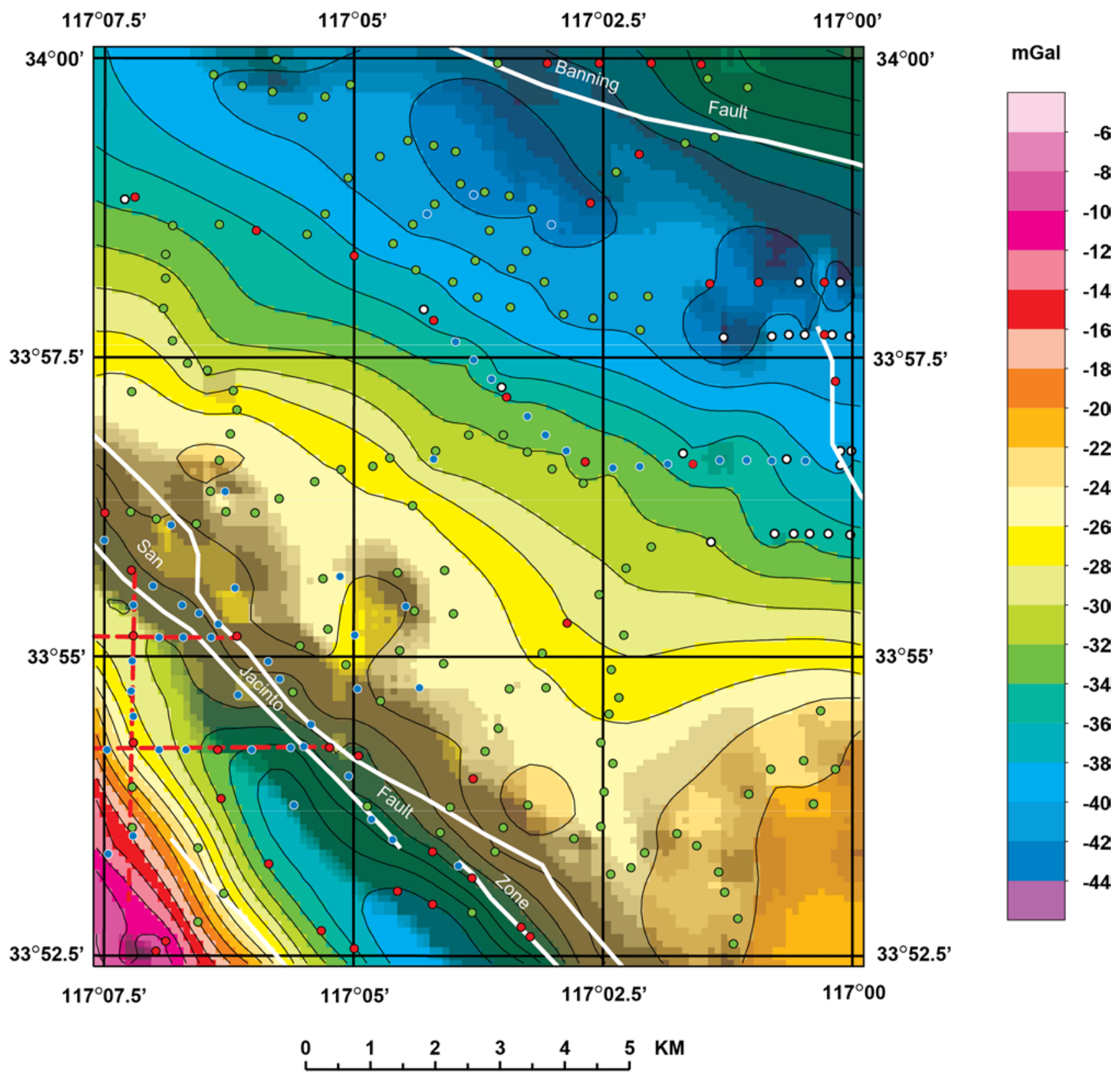

Gravity stations

- U.S.Geological Survey

- U.S. Geological Survey (older data)

- U.C. Riverside

- Defense Mapping Agency

Seismic lines (Park and others, 1995)

Figure 42. Map of isostatic gravity for El Casco 7.5' quadrangle (derived from map sheet 3 of 3 ). White lines are faults. 


\title{
DESCRIPTION OF MAP UNITS
}

\author{
[By J.C. Matti ${ }^{1}$ and D.M. Morton ${ }^{2}$ ]
}

\section{QUATERNARY SURFICIAL DEPOSITS}

Very young surficial deposits - Sediment recently transported and deposited in channels and washes, on surfaces of alluvial fans and alluvial plains, in ephemeral lakes, and on hillslopes. Soil-profile development nonexistent to weak. Includes the following:

Very young wash deposits (uppermost Holocene) — Sandy and gravelly sediment associated with stream channels and arroyos that are sites of very recent sediment transport and deposition. Includes the following: Very young wash deposits, modern (uppermost Holocene) - Very slightly consolidated sandy and gravelly sediment in active washes of axial-valley streams and alluvial fans. Occurs mainly as sediment in channels and arroyos incised into older map units; has fresh flood scours, bar-and-channel morphology, and ephemeral sandy and gravelly bedforms. Most extensive in San Timoteo Creek and its tributary drainages and in north-heading canyons incised into San Timoteo Badlands. Sandy sediment typically is white (10YR $8 / 1$ and $8 / 2$ to $2.5 \mathrm{Y} 8 / 2$ ), and ranges from fine to coarse sand to slightly gravelly sand and gravelly sand; gravelly sediment includes sandy gravel and muddy sandy gravel, with gravel minor. Grain size and sorting vary from place to place, with sandy sediment predominating in western parts of San Timoteo Creek drainage and gravel-sized constituents increasing upstream to east and northeast; sediment in canyons of San Timoteo Badlands strongly influenced by sandy or conglomeratic character of underlying San Timoteo formation of Frick (1921). Gravel-size clasts range from pebbles to small cobbles. Pedogenic-soil development generally nonexistent because of frequent flooding

Very young wash deposits, Unit 2 (modern) - Very slightly to slightly consolidated sandy and gravelly sediment that locally forms slightly elevated terraces along margins of San Timoteo Creek. Appears to be intermittently active based on fresh channel scouring, probably active during 1938 flood events. No significant pedogenic-soil development, although organic horizon may be present locally

Qvyw1 $_{1} \quad$ Very young wash deposits, Unit 1 (modern) - Very slightly to slightly consolidated sandy and gravelly sediment that locally forms slightly elevated terraces along margins of San Timoteo Creek; probably abandoned by modern stream flows, although may include intermittently active deposits. Surface supports mature trees and thin A horizons

Qvyf

Very young alluvial-fan deposits (uppermost Holocene) - Very slightly to slightly consolidated, undissected deposits of sandy and gravelly sediment that form actively sedimented parts of alluvial fans; occurs only locally in quadrangle. Lacks pedogenic-soil development

Qvylm Very young lacustrine deposits, modern (uppermost Holocene) - Very slightly to slightly consolidated, undissected muddy and sandy sediment that occurs in San Jacinto Valley in south part of quadrangle; interpreted by 
Morton and Matti (2000, their unit QIv) as interlayered lacustrine and alluvial deposits. Consists of gray, interbedded clay, silt, and fine sand; upper surface marked by numerous ground fissures (Morton, 1977). Muddy sediment deposited by suspension deposition in ephemeral lake that forms in highrainfall years by overbank flooding of San Jacinto River ("Mystic Lake" of local usage); sandy sediment deposited by streamflows of San Jacinto River and by streamflows sourced from San Timoteo Badlands

Young surficial deposits - Sedimentary units that are very slightly to moderately consolidated and slightly to moderately dissected. Alluvial-fan deposits (Qyf series) typically are sandy, but include subordinate gravelly sediment; axialvalley deposits (Qya series) are dominated by sandy sediment, with minor gravelly sediment and uncommon muddy sediment. Upper surfaces capped by slight to moderately developed pedogenic-soil profiles $\left(\mathrm{A} / \mathrm{AC}\right.$ to $\mathrm{A} / \mathrm{AC} / \mathrm{B}_{\text {cambic }}$ profiles having oxidized upper $\mathrm{C}$ horizon). Soil groups mapped by Knecht (1971) mainly are Hanford and San Emigdio series, but include Metz, Tujunga, and Grangeville series

Young axial-valley deposits (Holocene and uppermost Pleistocene) - Sandy, muddy, and gravelly sediment deposited by throughgoing streams of axial valleys; subunits distinguished on the basis of soil-profile development, relative position in local terrace-riser succession, and degree of erosional dissection. Includes one of five subunits recognized regionally: gravelly sediment that occurs in drainages of San Timoteo Creek and in canyons of San Timoteo Badlands. Throughout quadrangle, unit appears to represent latest Holocene depositional event that backfilled canyons in San Timoteo drainage and San Timoteo Badlands. Occurs in two major areas:

San Timoteo drainage - Unit Qya ${ }_{5}$ forms much of uppermost sedimentary fill of San Timoteo Canyon and its northern tributaries, where unit consists of sandy and silty sediment and subordinate slightly gravelly sediment that underlies main geomorphic surface of axial valley and its major tributaries. Exposed only in arroyo walls. Unit typically is white to light-gray ( $2.5 \mathrm{Y} 8 / 2$ and $7 / 2$ to $10 \mathrm{YR} 8 / 1$ and $8 / 2$ ), but ranges to pale yellow $(2.5 \mathrm{Y} 7 / 4)$ and rarely light yellowish brown $(2.5 \mathrm{Y} 6 / 4)$; finer grained sediment tends to be darker. Clasts range from pebbles to small cobbles, are rounded to subangular, and consist of granitic and gneissic rocks of San Bernardino Mountains type and foliated to mylonitic granitoid and gneissic rocks of San Gabriel Mountains-type; these both probably are first-cycle clasts derived from local basement outcrops north of Banning Fault and second-cycle clasts derived from the sedimentary deposits of Live Oak Canyon. Where penetrated by Caltrans bridge borings along Interstate Highway 10, consists of poorly sorted fine to coarse sand with pebble gravel.

San Timoteo Badlands-Unit Qya ${ }_{5}$ forms much of uppermost sedimentary fill of canyons that head north into San Timoteo Badlands from San Jacinto Valley; fills typically debouch into San Jacinto Valley as alluvialfan deposits that are difficult to distinguish lithologically from upstream axialvalley deposits of canyons. Unit typically is white to light-gray $(2.5 \mathrm{Y} 8 / 2$ and $7 / 2$ to 10 YR $8 / 1$ and $8 / 2$ ). Clasts range from pebbles to small cobbles, are 
rounded to subangular, and consist of foliated to mylonitic granitoid and gneissic rocks of San Gabriel Mountains-type (second-cycle clasts derived from the San Timoteo formation of Frick, 1921)

Young alluvial-fan deposits (Holocene and uppermost Pleistocene) - Sandy, gravelly, and muddy sediment deposited by streams flowing on alluvial-fan landforms; subunits distinguished from each other on the basis of soil-profile development, relative position in local terrace-riser succession, and degree of erosional dissection. Includes three of five subunits recognized regionally:

Young alluvial-fan deposits, Unit 5 (upper Holocene)-Sandy and gravelly sediment that occurs in two main areas:

Alluvial-fan fills of San Timoteo Creek-In central part of quadrangle, unit Qyf $_{5}$ along San Timoteo Creek and its tributaries. Along both south and north margins of San Timoteo Creek unit forms undissected to slightly dissected, cone-shaped surfaces that extend from side canyons downslope toward throughgoing axial stream of San Timoteo Creek; locally fan cones constrict axial-valley deposits to a narrow incised channel. Unit typically is white to light-gray $(2.5 \mathrm{Y} 8 / 2$ and $7 / 2$ to $10 \mathrm{YR} 8 / 1$ and $8 / 2)$, but ranges to pale yellow (2.5Y 7/4) and rarely light yellowish-brown (2.5Y 6/4). Clasts range from pebbles to small cobbles, are rounded to subangular, and have compositions that vary according to geographic location: on north side of San Timoteo Canyon consist of granitic and gneissic rocks of San Bernardino Mountains type and foliated to mylonitic granitoid and gneissic rocks of San Gabriel Mountains-type; on south side of San Timoteo Canyon consist of foliated to mylonitic granitoid and gneissic rocks and porphyritic dike rocks of San Gabriel Mountains-type (second-cycle clasts derived from the San Timoteo formation). In west part of quadrangle, unit Qyf $f_{5}$ is well developed on both north and south margins of San Timoteo Creek; in east part of quadrangle, unit $\mathrm{Qyf}_{5}$ is well developed on south margin all way to east edge of quadrangle, but on north margin fan deposits diminish eastward and are replaced by throughgoing axial-valley deposits of north-heading tributary streams. Alluvial-fan deposits of unit $\mathrm{Qyf}_{5}$ appear to be in equilibrium geomorphically and hydraulically with axial-valley deposits of unit Qya. Fans on north side of San Timoteo Canyon have widths commensurate with their longitudinal extent; however, some fans on south side of Canyon appear to be too short relative to their width, suggesting that alluvial-fan deposits have occupied valleys truncated at their south ends.

Alluvial fan fills along southwest margin of San Timoteo Badlands-In southwest part of quadrangle, localized and poorly developed fan-shaped lobes of unit Qyf ${ }_{5}$ debouch from northeast- and north-heading canyons of San Timoteo Badlands, and form thin bodies on top of underlying unit $\mathrm{Qyf}_{3}$. Boundaries of bodies are difficult to recognize and map due to agricultural modification. One exception is fan-shaped sediment body radiating from mouth of unnamed canyon directly west of Jackrabbit Trail: developed from sediment of units $\mathrm{Qyf}_{5}$ and $\mathrm{Qyf}_{3}$, this fan is sufficiently long-lived that it has maintained itself as a discrete landscape element despite forming within rightlateral San Jacinto Fault zone, suggesting lack of Holocene activity on Claremont strand of fault that traverses fan. Unit Qyf $f_{5}$ typically is white to light-gray (2.5Y 8/2 and 7/2 to $10 \mathrm{YR} 8 / 1$ and 8/2). Clasts range from pebbles 
to small cobbles, are rounded to subangular, and consist of foliated to mylonitic granitoid and gneissic rocks and porphyritic volcanic-dike rocks of San Gabriel Mountains-type (second-cycle clasts derived from the San Timoteo formation of Frick, 1921). Unit Qyf $_{5}$ does not appear to be faulted by strands of San Jacinto Fault anywhere along south margin of San Timoteo Badlands

Qyf $_{4}$

Qyf $_{3}$

Qyf $_{1}$

Qyl5

Qyls

Young alluvial-fan deposits, Unit 4 (upper Holocene) - Occurs locally in southwest part of quadrangle, where unit forms isolated alluvial-fan surfaces underlain by very slightly to slightly consolidated sandy and gravelly sediment. Identified mainly on the basis of photogeologic criteria Young alluvial-fan deposits, Unit 3 (middle Holocene)—Sandy and gravelly sediment occurring mainly in two areas:

Fan deposits radiating from San Timoteo Badlands-In southwest part of quadrangle, coalesced alluvial fans emanating from canyons incised into San Timoteo Badlands form an extensive surface that originates northwestward in Sunnymead quadrangle (Morton and Matti, 2001) and slopes gently southeastward to San Jacinto Valley; sandy and slightly gravelly deposits have weakly developed A/C and A/AC soils mapped by Knecht (1971) as San Emigdio loam and fine sandy loam (units $\mathrm{SgC}$ and $\mathrm{SeC} 2$ ); soil profiles generally are less than $1 \mathrm{~m}$ thick, and their $\mathrm{C}$ horizons are not oxidized. Although we have no solid age control for these deposits, we suspect they are part of a middle to upper Holocene fill series that is developed elsewhere in Inland Empire region; hence we assign them to unit Qyf $_{3}$. Claremont strand of San Jacinto Fault locally forms conspicuous but discontinuous scarps in coalesced-fan surface. Unit also forms conspicuous alluvial-fan cone radiating from mouth of unnamed canyon directly west of Jackrabbit Trail (discussed above under unit $\mathrm{Qyf}_{5}$ ).

San Timoteo Creek drainage basin-In northwest part of quadrangle we map a small remnant body of unit $\mathrm{Qyf}_{3}$ preserved beneath unit $\mathrm{Qyf}_{5}$. This body is recognized based on aerial photographic interpretation, and its stratigraphic position is based on its slight incision by unit $\mathrm{Qyf}_{5}$ and by throughgoing streamflows of San Timoteo Creek

Young alluvial-fan deposits, Unit 1 (lower Holocene and uppermost Pleistocene) - Sandy and gravelly sediment occurring locally along south margin of San Timoteo Badlands; identified on basis of aerial photographic interpretation. Underlies and is older than sediment we map as unit Qyf

Young lacustrine deposits, Unit 5 (uppermost Holocene) - Very slightly to slightly consolidated, undissected muddy and sandy sediment that occurs in San Jacinto Valley in south part of quadrangle; interpreted by Morton and Matti (2001, their unit Qv) as very young alluvial valley deposits, although in El Casco quadrangle probably mainly lacustrine in origin representing late Holocene equivalent of "Mystic Lake" (local usage for ephemeral lake that forms in high-rainfall years by overbank flooding of San Jacinto River)

Young landslide deposits (Holocene and uppermost Pleistocene) Undissected to slightly dissected slope-movement deposits that consist of chaotically mixed soil and rubble and (or) displaced bedrock blocks; most emplaced as debris slides and rock slumps or earth slumps (terminology 
follows Varnes, 1978, fig. 2.1). Locally may include older inactive landslide material. Especially abundant on south flank of San Timoteo Canyon, where numerous slope-movement masses have been shed from north-dipping sequence of middle member of the San Timoteo formation of Frick (1921). Some of these masses consist of discrete blocks (rock slides and rock slumps of Varnes, 1978) displaced downslope to north

Old surficial deposits - Sedimentary units that are moderately consolidated and slightly to moderately dissected. Alluvial-fan deposits (Qof series) typically are gravelly, but include sandy and silty sediment. Axial-valley deposits (Qoa series) are dominated by sandy sediment with minor gravelly sediment. Upper surfaces capped by moderately to well-developed pedogenic soils $\left(\mathrm{A} / \mathrm{AB} / \mathrm{B} / \mathrm{C}_{\text {ox }}\right.$ profiles and $\mathrm{Bt}$ horizons as much as 1 to $2 \mathrm{~m}$ thick and maximum hues typically in range of $10 \mathrm{YR} 5 / 4$ and 6/4 [yellowish brown and light yellowish brown] through 7.5YR 6/4 to 4/4 [light brown to dark brown] but reaching 5YR 5/6 [yellowish red]). Soil groups mapped by Knecht (1971) include Greenfield series and weaker soils of Monserate and Ramona series

Qosu

Qoau

$\mathrm{Qof}_{3}$

Qof $_{2}$

Old surficial deposits, undifferentiated (upper to middle Pleistocene) - Sandy and gravelly sediment of unspecified genesis

Old axial-valley deposits (upper to middle Pleistocene) - Moderately consolidated sandy and silty sediment and subordinate gravelly sediment deposited by throughgoing streams of axial valleys; subunits distinguished from each other on the basis of soil-profile development, relative position in local terrace-riser succession, and degree of erosional dissection

Old axial-valley deposits, undifferentiated (upper to middle Pleistocene)

-Brownish, sandy and gravelly sediment occurring locally along south margin of San Timoteo Badlands

Old alluvial-fan deposits (upper to middle Pleistocene)-Moderately consolidated sandy, gravelly, and silty sediment deposited by streams that formed alluvial-fan landforms; subunits distinguished from each other on the basis of soil-profile development, relative position in local terrace-riser succession, and degree of erosional dissection. Two of three old alluvial-fan units recognized regionally $\left(\right.$ Qof $_{2}$, Qof $_{1}$ ) occur in quadrangle:

Old alluvial-fan deposits, Unit 3 (upper to middle Pleistocene) - Occurs mainly in southwest part of quadrangle, where unit identified on the basis of aerial photography; consists of brownish sandy and gravelly sediment

Old alluvial-fan deposits, Unit 2 (upper to middle Pleistocene)-Occurs mainly in north part of quadrangle underlying widespread alluvial-terrace surface (Beaumont Plain of Young and others, 1941); originally formed extensive alluvial-fan complex that buttressed unconformably against highstanding landscape of the sedimentary deposits of Live Oak Canyon and middle member of the San Timoteo formation. Consists of moderately consolidated, brownish sandy and gravelly sediment capped by pedogenic soil having well-developed argillic horizon; sandy sediment mainly sand, slightly gravelly sand, and gravelly sand; gravelly sediment mainly sandy gravel and pebble-cobble gravel. Clasts rounded to angular, consisting of granitic and gneissic rocks of San Bernardino Mountains type (first-cycle) and foliated to mylonitic granitoid and gneissic rocks of San Gabriel Mountains-type (first- 
cycle clasts derived from basement outcrops north of Banning Fault). Soil profiles mapped by Knecht (1971) as Ramona series (units RaB2, ReC2, $\mathrm{RaC} 3$ ). Where penetrated by Caltrans bridge borings 56-483 and 56-481 consists of reddish brown to brown, poorly sorted, micaceous, fine to coarse sand and clayey and silty sand interbedded with minor poorly sorted granulebearing sand and granule-pebble gravel; penetration resistance $\mathrm{N}$ commonly $>50$

Qof $_{1}$

Qofu

Qols

Qvors

Qvoau

Old alluvial-fan deposits, Unit 1 (upper to middle Pleistocene)-Brownish sandy and gravelly sediment occurring along east-central edge of map area. Unit deposited as thin veneers on erosional strath surfaces incised into unit Qvof $_{3}$

Old alluvial-fan deposits, undifferentiated (upper to middle Pleistocene)

-Brownish sandy and gravelly sediment occurring locally along south margin of San Timoteo Badlands. Along southwest margin of Mt. Eden basement inselberg, unit forms thin veneers on erosional strath surfaces incised into members of Mt. Eden formation of Frick (1921); contains clasts of Mt. Eden beds, as well as clasts of various crystalline rocks derived from Mt. Eden

Old landslide deposits (upper to middle Pleistocene) - Occurs in south part of quadrangle, west of mouth of large unnamed canyon directly west of Jackrabbit Trail. Consists of well-dissected, chaotically mixed soil and rubble emplaced as debris slides and earth slumps; not clear whether mass contains intact blocks that have been displaced by rotational slumping or translational sliding (terminology follows Varnes, 1978, fig. 2.1). Derived from lower member of San Timoteo formation that crops out directly to north

Very old surficial deposits - Sedimentary units (Qvo series) that are moderately consolidated and moderately to well dissected. In quadrangle, consists mainly of alluvial-fan deposits (Qvof units) that typically are sandy and gravelly, but locally includes muddy sediment; axial-valley deposits (Qvoa units) not well represented in quadrangle. Upper surfaces capped by moderate to welldeveloped pedogenic soils $\left(\mathrm{A} / \mathrm{AB} / \mathrm{B} / \mathrm{C}_{\text {ox }}\right.$ profiles having $\mathrm{Bt}$ horizons as much as 2 to $3 \mathrm{~m}$ thick and maximum hues in range of 7.5YR 6/4 to 4/4 [light brown to dark brown] to 2.5YR 5/6 [red]). Soil groups mapped by Knecht (1971) include stronger soils of Ramona and Placentia series

Very old residuum and (or) pedogenic soil (middle to lower Pleistocene) Consists of residuum and (or) pedogenic-soil profile developed on the sedimentary deposits of Live Oak Canyon; has mature A/AB/B soil profile having $\mathrm{Bt}$ horizon as much as $2 \mathrm{~m}$ thick, and commonly laced with stringers, nodules, and irregular seams of $\mathrm{CaCO}_{3}$ (caliche)

Very old axial-valley deposits (middle to lower Pleistocene)-Moderately to well consolidated deposits having subunits distinguished from each other on the basis of soil-profile development and relative position in local terrace-riser succession. Includes the following:

Very old axial-valley deposits, undifferentiated (middle to lower Pleistocene) - Brownish sandy and gravelly sediment perched on low ridge crests along Laborde Canyon 
Very old alluvial-fan deposits (middle to lower Pleistocene)-Sandy and gravelly deposits having subunits distinguished from each other on the basis of soil-profile development and relative position in local terrace-riser succession

Qvof $_{3} \quad$ Very old alluvial-fan deposits, Unit 3 (middle Pleistocene) - Occurs in eastcentral part of quadrangle in Beaumont Plain area, where unit consists of brownish sandy sediment capped by well-developed soils having argillic $\mathrm{Bt}$ horizons as much as $2 \mathrm{~m}$ thick

\section{CENOZOIC SEDIMENTARY DEPOSITS}

Qlo Sedimentary deposits of Live Oak Canyon (new) (Pleistocene) —Consists of nonmarine sandy and gravelly sediment; lithified equivalents (sandy and conglomeratic rock) are subordinate. Age Pleistocene based on correlation with dated deposits in nearby quadrangles: (1) in Redlands quadrangle, magnetostratigraphic data (Albright, 1997, 1999) indicate that uppermost beds of unit Qlo postdate Brunhes-Matuyama magnetic reversal, and thus are younger than about $780 \mathrm{ka}$ (see Matti and others, 2003a, for location of magnetostratigraphic profile); (2) in Yucaipa quadrangle (Matti and others, 2003a), upper part of unit Qlo contains middle Pleistocene (Irvingtonian-II) Shutt Ranch vertebrate local fauna dated as about 780 to $990 \mathrm{ka}$ (Reynolds and Reeder, 1986; Albright, 1999); (3) in Redlands quadrangle, beds of underlying San Timoteo Formation (upper member) contain early Pleistocene (Irvingtonian-I) Olive Dell local fauna dated at about 1.3-1.5 Ma (Morton and others, 1986; Repenning, 1987; Morton and Matti, 1993, p. 221; Albright, 1997, 1999). North of San Timoteo Canyon the sedimentary deposits of Live Oak Canyon overlies these deposits, indicating that Live Oak Canyon strata are younger than 1.3-1.5 Ma.

Unit consists of both unconsolidated and consolidated sedimentary material. Sediment typically is moderately consolidated; rock is well consolidated to lithified. Mainly consists of sandy sediment and sandy rock interbedded with subequal to subordinate gravelly sediment and conglomeratic rock; muddy sediment and mudrock are minor. Where exposed in northeast part of quadrangle, lower contact of member is angular unconformity; upper contact is erosional, or unconformable with overlying surficial materials.

Sandy sedimentary material: Typically subdued and slope forming. Medium to thick bedded on average, but includes thin-bedded intervals; parallel-bedded to lenticular, locally with channelate lower surfaces. Stratification defined by variations in grain size, color, and (or) depositional fabric. Typically yellowish, including light yellowish-brown to olive yellow (2.5Y 6/4 to 6/6) and light olive brown (2.5Y 5/6); locally, beds are browner, including brownish-yellow to yellowish-brown (10YR 6/6 to 5/6) and strong brown (7.5YR 6/6 to 5/6) to pale brown (10YR 6/3). Typical unconsolidated lithologies include muddy sand, sand, slightly gravelly sand, and gravelly sand; typical consolidated lithologies include muddy sandstone, sandstone, slightly gravelly sandstone, and gravelly sandstone. Sorting ranges from moderate to very poor, with sand size grains typically ranging from very fine to very coarse and gravel-size clasts ranging from granules to small cobbles. 
Depositional textures range from massive to flat-laminated and cross-

laminated. Framework grains mainly lithic and quartzose, subordinate feldspar and biotite; where present, cement is calcite and (or) silica.

Gravelly and conglomeratic sedimentary material: Typically slope forming, although better consolidated sediment and cemented rock locally form hard prominent ledges. Medium- to thick-bedded on average, with stratification defined by variations in grain size; typically lenticular with channelate lower surfaces, although locally strata are parallel bedded. Sandy matrix of gravel beds is lighter colored than sandy sediment and rock, and ranges from light gray to pale yellow and light yellowish brown $(2.5 \mathrm{Y} 7 / 2$ to $6 / 4$ ) and white to light gray (10YR 8/1 to 7/1). Typical unconsolidated lithologies include gravel and sandy gravel; typical consolidated lithologies include conglomerate and sandy conglomerate. Sorting typically is poor, with clast size ranging from pebbles to small boulders (maximum size about 0.5 $\mathrm{m})$; small cobble-size is typical. Depositional textures range from massive to flat-laminated and rarely cross bedded; clast imbrication common, with paleocurrent indicators pointing to southwest and south. Clasts are subrounded to angular, and include basement rocks of both San Gabriel Mountains-type (dominantly mylonitic and nonmylonitic granitoids from upper plate of Vincent Thrust; also includes porphyritic volcanic-dike rocks, distinctive clasts of white aplite and pegmatite, and sparse grayschist and greenstone varieties of Pelona Schist) and San Bernardino Mountains-type (granitoid and gneissic rocks)

San Timoteo formation of Frick (1921) (Quaternary and Tertiary) - Nonmarine sedimentary rock referred to by Frick (1921, p. 283, 317) as his "San Timoteo formation" or "Upper San Timoteo Deposition". Sandy and conglomeratic rocks contain clasts derived from crystalline rocks of Transverse Rangestype; clasts of Peninsular Ranges-type do not occur. Throughout its regional extent, formation ranges in age from Pliocene to early Pleistocene (Albright, 1997, 1999). Until a type section is designated and described, map unit is classified informally. Subdivided into lower, middle, and upper members (Matti and Morton, 1975; Morton, 1999), with only lower and middle members occurring in El Casco quadrangle:

QTstm Middle member (Pliocene) - Forms middle part of San Timoteo formation of Frick (1921). Unit consists of four principal lithotypes that recur throughout sequence: (1) thick sheetlike layers of conglomeratic rock; (2) light-gray to white sandstone and slightly conglomeratic sandstone; (3) reddish mudstone and sandstone; and (4) locally significant but minor grayish-green mudrock. Lithologies (1) and (3) distinguish middle member from other members of formation. Lower contact is transitional across intervals as thick as $50 \mathrm{~m}$, and appears to interfinger southeastward and eastward with underlying sandstone unit of lower member (unit Tstls); upper contact is not exposed in quadrangle, but in adjacent Sunnymead quadrangle middle member is transitional with overlying upper member (Morton and Matti, 2001). Age is Pliocene (Blancan) based on magnetostratigraphic correlation (Hehn and others, 1996; Albright, 1997, 1999) and stratigraphic relations with underlying and overlying units that contain vertebrate fossils (Albright, 1997, 1999). 
Sheetlike conglomerate-Most characteristic lithotype in middle member. Consists of well consolidated to lithified beds and amalgamated layers of white to light-gray pebble-cobble conglomerate as much as $10 \mathrm{~m}$ thick that typically forms resistant cliffs and bluffs of prominent ledgeforming outcrops. Beds exclusively contain clasts of San Gabriel Mountainstype basement rock, including massive and foliated granitoid rocks; mylonitic, gneissic, and foliated rock of upper plate of Vincent Thrust; hypabyssal granitoid rock; porphyritic volcanic-dike rock; and Pelona Schist greenstone that occurs in stratigraphically higher parts of middle member). We have not observed basement clasts of either San Bernardino Mountains-type basement or "black-belt" mylonite or charnockitic and granulitic rock that form southeastern bedrock front of San Gabriel Mountains (Morton and Matti, 1987).

Rock typically ranges from conglomerate to sandy conglomerate that is medium to very thick bedded; layers typically parallel bedded, but grossly lenticular across distances of several hundred meters; basal surfaces locally channelate. Stratification defined by variations in grain size and by flat lamination that is crude but pervasive. Clast size typically small cobbles (7-8 $\mathrm{cm}$ ), but ranges from pebbles to small boulders (maximum size about $25 \mathrm{~cm}$ ). Clasts rounded to subrounded typically, but subangular and angular clasts occur in some beds. Clast imbrication common; paleocurrent indicators point to southeast and south. Fluvial in origin, and probably represent braidplain gravel-bed deposits. Only in northeast part of quadrangle adjacent to Banning Fault does unit locally contains coarser grained bouldery beds that are matrixsupported and probably are debris-flow deposits; these beds have clasts very similar to crystalline rocks directly north of Banning Fault, indicating very local derivation.

White to light-gray sandy rock-Interbedded with sheetlike conglomeratic layers are light-colored sandy beds similar to those at other levels in the San Timoteo formation. Well consolidated to lithified, locally well cemented. Bedding thickness variable, medium to very thick typically; stratification defined by color, by variations in gravel-size clasts, and by changes in depositional fabric. Generally light colors range from white to very pale brown and light gray (10YR 8/1,8/2 typically, also 10YR 7/1, 7/2 and $2.5 \mathrm{Y} 8 / 2$ to $7 / 2$ ). Fabric texturally massive to pervasively flat-laminated; locally cross-stratified (tabular to trough cross stratification). Sorting very good to poor; grain size very fine sand to coarse sand containing variable gravel-size particles; particles subrounded to subangular. Typical lithotypes include (1) fine to coarse sandstone, (2) muddy fine to medium sandstone, (3) and poorly sorted slightly gravelly and gravelly sandstone and muddy sandstone. Grain composition is lithic and quartzose, with subordinate biotite and feldspar. Fluvial in origin, probably distal braidplain sand-bed deposits.

Reddish-colored sandy rock and mudrock-Conspicuous in middle and upper parts of middle member are intervals of fine-grained rock that appear reddish-colored in contrast to lighter colored conglomeratic and sandy intervals. Consists of medium to very thick recessive intervals of slopeforming fine-grained sandy rock and mudrock that are texturally massive to faintly laminated and contain floating grains of very coarse sand and granules. 
Sandy lithologies include silty very fine to fine sandstone and clayey sandstone; mudrock lithologies include mudstone, siltstone, clayey siltstone, and sandy siltstone. "Reddish" colors actually are brownish to yellowish, and range from light yellowish brown and brownish yellow (10YR 6/4 and 6/6) to light brown and reddish yellow (7.5YR 6/4 to 7/4 and rarely 6/6). Texturally massive fabric and floating coarse grains suggest that most of these intervals are eolian in origin. Their reddish color and local clay content suggest a pedogenic origin for some of these intervals, but soil structure is not present in layers we examined.

Greenish-gray colored mudrock-Although not common in middle member, locally sequence has recessive slope-forming intervals of greenish and grayish mudrock that consists of texturally massive to faintly laminated mudstone and very fine sandstone. Typical colors include white to light gray $(2.5 \mathrm{Y} 8 / 1,8 / 2,7 / 1,7 / 2 ; 10 \mathrm{YR} 7 / 2)$ and light olive gray $(2.5 \mathrm{Y} 6 / 2)$. These materials probably accumulated as overbank deposits or as deposits in standing bodies of water (ponds, ephemeral lakes)

Lower member (Pliocene) - Forms lower part of San Timoteo formation of Frick (1921). Consists of three distinctive intervals that we map as informal units, including a sandstone unit (Tstls), a ripple-laminated unit (Tstlr), and a fine-grained unit (Tstlf). Three units interfinger with each other regionally, although in El Casco quadrangle they generally have superpositional stratigraphic relations

Tstls Sandstone unit (Pliocene) - Forms principal map unit within lower member. Consists mainly of sandy rock interbedded with sparse conglomeratic rock; mudrock minor, except in stratigraphic sequence west of Moreno Valley strand of San Jacinto Fault at west edge of quadrangle. Rock is well consolidated to lithified, with some intervals cemented by calcareous and (or) siliceous cement. Contact with overlying middle member (unit QTstm) is transitional over a stratigraphic interval as much as $50 \mathrm{~m}$ thick across which frequency and thickness of conglomeratic beds increases significantly; appears to interfinger northwestward with middle member. Boundary with underlying ripple-laminated unit (unit Tstlr) typically is not well exposed and varies throughout quadrangle: (1) in Laborde Canyon area, sandstone unit overlies ripple-laminated unit; (2) in Mt. Eden-Jackrabbit Trail area a lowangle normal fault of Laborde Canyon Fault zone appears to juxtapose sandstone unit against underlying units. Age is Pliocene (Blancan) based on vertebrate fossils collected by Frick (1921) and reexamined by Albright (1997, 1999), and based on magnetostratigraphic data (Hehn and others, 1996; Albright, 1999).

Sandy rock - Constitutes as much as $90 \%$ of unit. Consists mainly of very fine to medium sandstone, but ranges from mudstone to muddy sandstone to slightly gravelly sandstone. Less consolidated materials are poorly exposed and form slopes; cemented beds form prominent ledges. Rock is thin- to thick-bedded, commonly medium bedded, with stratification defined by changes in color, grain size, and sedimentary structures; stratification parallel bedded to grossly lenticular, locally channelate. Weathered outcrops are white to light-gray to very pale-brown (10YR 8/1, $8 / 2,7 / 1,7 / 2 ; 7 / 3)$; fresh surfaces are white to very pale brown (10YR $8 / 1$ to 
$8 / 3$ ). Sedimentary structures typically massive to flat laminated; cross lamination includes tabular cross lamination and small-scale trough lamination. Sorting very good to moderate, less commonly poor. Grains dominated by quartz, lithic fragments, and biotite, with feldspar typically less than $15 \%$; at east of edge of quadrangle where member buttresses against unit $\mathrm{Ktlc}$, rock is more feldspathic and reflects grusy sediment input from local Peninsular Ranges-type basement source. Particles subrounded to subangular, rarely rounded and angular. Fluvial in origin, probably distal braidplain sandbed deposits.

Conglomeratic rock - Constitutes less than 10\% of unit, except within transitional zone with overlying middle member; ranges from sandy conglomerate to conglomerate. Less consolidated materials are poorly exposed and slope forming; cemented beds form ledges. Thin- to mediumbedded, rarely thick bedded, with stratification defined by grain-size contrasts with enclosing sandy rock. Layers typically are lenticular and pinch out over short distances. Both weathered and fresh outcrops are white to light-gray (10YR 8/1, 8/2,7/1). Sedimentary structures are massive to crudely flat laminated; cross stratification less common; clasts commonly imbricated. Clasts range from pebbles to small cobbles, and are rounded to subangular, rarely angular. All clasts are of San Gabriel Mountains-type: in order of decreasing abundance these consist of resistant types like massive and foliated leucocratic granitoid rocks, aplite, texturally massive porphyritic hypabyssal granitoid rocks, biotite-quartz gneiss, and porphyritic volcanic rock. Fluvial in origin, probably low-energy distal braidplain gravel-bed deposits; paleocurrent indicators (imbrications) point to southeast and south.

Mudrock-Sandstone unit sequence locally includes recessive slopeforming intervals of greenish and grayish mudrock that consists of texturally massive to faintly laminated mudstone and very fine sandstone. Typical colors include white to light gray $(2.5 \mathrm{Y} 8 / 1,8 / 2,7 / 1,7 / 2 ; 10 \mathrm{YR} 7 / 2)$ and light olive gray $(2.5 \mathrm{Y} 6 / 2)$. These materials probably accumulated as overbank floodplain deposits or as deposits in standing bodies of water (ponds, ephemeral lakes)

Ripple-laminated unit (Pliocene) - Occurs in lower part of San Timoteo formation of Frick (1921). Consists of two distinctive interbedded lithologies: ledge-forming ripple-laminated sandstone and recessive greenish-gray mudstone. Upper and lower boundaries vary throughout quadrangle. In Laborde Canyon area, unit is overlain abruptly by sandstone unit of lower member (unit Tstls); in Mt. Eden area, two units are juxtaposed by Laborde Canyon Fault. Lower contact is transitional with underlying fine-grained unit of lower member (unit Tstlf). East of Laborde Canyon, ripple-laminated unit has a distinctive orange-red color that probably reflects oxidation or staining by iron-charged groundwater percolating through unit during or after its deposition. Age Pliocene (Blancan) based on magnetostratigraphic correlation (Hehn and others, 1996; Albright, 1997, 1999) and stratigraphic relations with underlying and overlying units that contain vertebrate fossils (Albright, 1997, 1999). 
Sandy rock - Consists of hard, well-consolidated to cemented, ledgeforming, thin and medium beds of sandstone and minor silty sandstone. Color ranges from light gray to very pale brown (10YR $7 / 2$ to $7 / 3 ; 2.5 \mathrm{Y} 7 / 2)$ to light brownish gray (2.5Y 6/2). Very even layering with parallel-sided beds; stratification defined by contrasts with enclosing mudrock and by variations in sedimentary structures. Sandstone beds are flat-laminated and ripplelaminated (climbing ripples, small-scale tabular-ripple co-sets, trough-ripple co-sets); bed bases commonly have load-and-founder structures (ball-andpillow structures, detached pillows, flame structures); convolute lamination occurs locally. Particle sorting excellent to good, with particle size typically ranging from very fine to medium sand; coarse-sand size less common. Grain composition quartzose and lithic, with variable biotite; some beds contain mudrock intraclasts. Small-scale tabular, trough, and climbing-ripple laminations suggest low-energy fluvial conditions on a distal sand-bed floodplain proximal to standing water bodies (represented by mudrock interbeds).

Greenish-gray mudrock-Recessive, slope-forming, thin to medium intervals of greenish and grayish mudrock that is texturally massive to faintly laminated; weathers into small chips and platelets, and locally is fissile. Lithotypes include mudstone, silty claystone, and clayey siltstone. Color ranges from light gray to light olive gray and pale olive $(2.5 \mathrm{Y} 7 / 2,6 / 2,6 / 3)$ to light brownish gray (10YR 6/2). Locally has mudcracks, raindrop impressions, and lenticular calcareous concretions; locally gypsiferous. Contains small gastropods and ostracods. Accumulated as low-energy deposits in standing body of water (pond, ephemeral lake); gypsum suggests evaporation on a playa flat

Fine-grained unit (Pliocene) - Unit forms two intervals in lower part of San Timoteo formation: (1) an interval beneath ripple-laminated unit (Tstlr) that thickens eastward toward Beaumont and San Jacinto quadrangles, and (2) a stratigraphically higher tongue that pinches out westward into lower part of sandstone unit (Tstls). Age is Pliocene (Blancan) based on magnetostratigraphic correlation (Hehn and others, 1996; Albright, 1997, 1999) and stratigraphic relations with strata that contain vertebrate fossils (Albright, 1997, 1999).

Consists mainly of light-gray to grayish-brown $(2.5 \mathrm{Y} 7 / 2,6 / 2$, and $5 / 2)$ mudstone and calcareous mudstone that are fissil-weathering and chippyweathering, and that form recessive slopes prone to downslope movement. Specific lithologies include claystone, silty claystone, siltstone, and very fine biotitic sandstone. Rock is texturally massive to faintly laminated, locally has mudcracks and raindrop impressions, and locally contains thin gypsum nodules, needles, and seams. Accumulated under low-energy conditions, and most likely is lacustrine in origin; probably formed in a playa setting that periodically was flooded with shallow water that persisted long enough to yield fine-grained suspension deposits

Mt. Eden formation of Frick (1921) (revised) (Tertiary) - Nonmarine sedimentary rock referred to by Frick (1921, p. 283, 317) as his "Eden formation" or "Lower San Timoteo Deposition". Upper part of formation is late Miocene in age (late Hemphillian) on the basis of vertebrate fossils collected from Mt. 
Eden area (Frick, 1921; May and Repenning, 1982; Albright, 1997, 1999). Until a type section is designated, unit is classified informally. Subdivided into the following:

Tmeh Heterogeneous member (upper Miocene)-In Mt. Eden area, forms upper part of "Eden formation" of Frick (1921). Includes several lithotypes, two of which Frick (1921) emphasized in his original characterization: (1) slopeforming, greenish-gray mudstone, and (2) white nodular and lenticular limestone. Also includes (3) lithic arkosic sandstone and conglomeratic sandstone, and (4) greenish-gray siltstone and fine biotitic sandstone. These lithotypes occur in variable proportions throughout member, although finer grained rocks occur mainly in upper part of unit. Sandy and conglomeratic rocks contain clasts derived exclusively from crystalline rocks of Peninsular Ranges-type. Most of vertebrate fossils collected by Frick (1921) are from this member where it crops out on north slope of Mt. Eden.

Greenish-gray mudrock: "Calcareous bluish and greenish shales" of Frick (1921, p. 335) are most distinctive rock type of heterogeneous member. Consists of light-gray and light brownish gray (2.5Y 7/2 to 6/2) texturally massive to faintly laminated mudstone that weathers into chips and thin wafers; locally concretionary. Typically slope forming, although locally forms hard prominent ledges. Resembles greenish mudrock in overlying fine-grained unit (unit Tstlf), but relations in Laborde Canyon area indicate that mudrock we assign to San Timoteo interval there is a different fine-grained interval than one we assign to heterogeneous member in Mt. Eden area. Lacustrine in origin.

White limestone: "Limestone breccia" of Frick (1921, p. 335) consists of white (5Y 8/1,8/2 to 10YR 8/1), indurated, nodular and lenticular thin and medium layers of limestone and calcareous mudrock, some containing floating sand- and granule-size quartz or lithic grains; commonly interlayered with greenish-gray mudrock lithotype. Some nodular and concretionary limestone may be diagenetic and (or) hydrothermal in origin, but most is probably freshwater limestone formed in ponds or lakes.

Lithic-arkosic sandstone and conglomeratic sandstone: Consists of well consolidated to lithified sandstone, slightly conglomeratic and conglomeratic sandstone, and sandy conglomerate that occur variably throughout unit but are more common lower in unit suprajacent to arkosic and lithic member (unit Tmea). On north slope of Mt. Eden forms lens of distinctive, very hard, ledge-forming sandstone to slightly conglomeratic sandstone interval stratigraphically beneath finer grained beds from which Frick (1921) collected many of his vertebrate fossils. Color and bedding variable: most beds light-brownish (very pale brown to pale brown and light brownish gray, 10YR $7 / 3,6 / 3$, and $6 / 2$ ), but are more greenish-brown or grayish-brown $(2.5 \mathrm{Y} 7 / 2,6 / 2$, and 6/4) where associated with mudrock; stratification ranges from thin- to very-thick bedded, with layers parallelbedded to lenticular and channelate across distances of a few tens of meters. Fabric ranges from massive to faintly flat-laminated; cross lamination less common. Clasts range from pebbles to small cobbles (maximum $15 \mathrm{~cm}$; average $5 \mathrm{~cm}$ ), and are subrounded to angular; clasts locally imbricated, with paleocurrent indicators pointing radially toward southwest all way around to 
Tmes

Tmea

northeast. Fluvial in origin.

Greenish-gray siltstone and fine biotitic sandstone: Typically

interlayered with greenish-gray mudrock lithology; consists of light-gray and light brownish gray ( $2.5 \mathrm{Y} 7 / 2$ to $6 / 2$ ), slope-forming to ledge-forming, thin and medium beds that typically are texturally massive to flat laminated

Sandstone member (upper Miocene) - Occurs on south side of Mt. Eden, at top of arkosic member. Unit forms thin lenticular interval of lithified, ledgeforming, light-gray, laminated to cross-laminated and crossbedded, moderately sorted to well sorted sandstone and slightly conglomeratic sandstone with minor granule conglomerate

Arkosic and lithic member (upper Miocene)-Forms most of Mt. Eden formation in both Mt. Eden area and Laborde Canyon. At any specified location unit is fairly homogeneous in lithology; however, areally unit in Mt. Eden area tends to be more brownish than in Laborde Canyon area, where rock tends to be more grayish. In all instances, rock is well consolidated to lithified, is recessive and slope-forming rather than ledge-forming, is thinbedded to very thick bedded to crudely stratified, and contains angular to subrounded particles derived exclusively from crystalline rocks of Peninsular Ranges-type (aplite, gneiss, metaquartzite, marble, schist, and granitoids). Sandy rock predominates over conglomeratic rock.

Brownish sandy and conglomeratic rock: West, south, and north of Mt. Eden, sandy and conglomeratic rocks of arkosic and lithic member generally are light brownish-gray to light brownish-green, probably reflecting their mixture of metamorphic and granitoid grains and clasts. Representative rock colors include very pale brown to pale brown (10YR 7/3, 6/3) and light gray, light brownish gray, and light yellowish brown $(2.5 \mathrm{Y} 7 / 2,7 / 4,6 / 2$, and $6 / 4)$. Depositional fabrics range from texturally massive to flat laminated and cross laminated (shallow trough laminations, small-scale tabular laminations); clasts in conglomeratic beds commonly imbricated. Stratification defined by color changes, changes in depositional fabric, and changes in grain size. Sorting moderate to poor; grains and clasts angular to subrounded.

Light-gray sandy and conglomeratic rock: In Laborde Canyon area, sandy rock predominates over minor conglomeratic rock, and generally is light-gray to light greenish-gray, probably reflecting quartz-feldspar-biotite granitoid composition of grains and clasts. Representative rock colors include white to light gray $(10 \mathrm{YR} 8 / 2,7 / 1,7 / 2)$, white and light gray $(2.5 \mathrm{Y} 8 / 2$, and $7 / 2$ ), and light gray, pale yellow, and pale olive (5Y 7/2, 7/3, and 6/3).

Depositional fabrics commonly are texturally massive, less commonly crudely flat laminated; cross laminations (shallow trough laminations, small-scale tabular laminations) present but not common; sedimentary structures better developed in finer grained rocks than coarser grained rocks. Stratification commonly crude, but where well developed is defined by color changes, changes in depositional fabric, and changes in grain size. Sorting moderate to poor; grains and clasts angular to subrounded. Clast composition dominated by fragments of granitoid rock; metamorphic types minor; many intervals with sand- and granule-size grains have a grusy appearance due to abundance of granitoid detritus. Traced from Laborde Canyon to summit massif of Mt. Eden, predominantly grayish beds progressively are interstratified with light- 
Tmeb Boulder conglomerate member (upper Miocene) - Consists of lenticular bodies of monolithologic conglomerate interstratified with unit Tmea. Particle size ranges from pebbles to boulders as much as $6 \mathrm{~m}$ in dimension, larger particles surrounded by grusy sand- and granule-size matrix; particles angular to rounded (Larsen, 1962, figs. 14-16). Particles consist exclusively of biotitehornblende tonalite identical to tonalite of Lamb Canyon (unit Ktlc), and were derived from that bedrock unit (Larsen, 1962; Morton and Matti, 2000). Deposited by debris flows and (or) by long-runout rock avalanches (sturzstroms)

\section{CRYSTALLINE ROCK OF SAN GABRIEL MOUNTAINS-TYPE}

fcr Foliated crystalline rock (Mesozoic) - Fine- to coarse-grained foliated to gneissose granodiorite, tonalite, and quartz diorite that have a variety of nonpenetrative and penetrative fabrics, including fractured, sheared, and crushed rock, brittle cataclastic fabrics (grain crushing and fracturing), and ductile mylonitic fabrics (milling, fluxion structure). Rock mainly biotitic and chloritic; hornblende subordinate to rare. Forms upper plate of regionwide Vincent Thrust of eastern San Gabriel Mountains (Ehlig, 1981)

\}d Diorite (Mesozoic) - Medium- to coarse-grained, texturally massive to slightly foliated hornblende-biotite diorite and quartz diorite. Age and intrusive relations with unit fcr uncertain

\section{CRYSTALLINE ROCK OF PENINSULAR RANGES-TYPE}

Kmeg Granite of Mt. Eden (Cretaceous) - Very pale-brown, texturally massive to foliated, inequigranular to coarse-grained muscovite-garnet monzogranite; locally forms dikelike masses. Mapped by Beyer (1959) and MacLeod (1961) as alaskite. Age relations with tonalite of Lamb Canyon (unit Ktlc) not known, but unit Kmeg probably is older based on sequencing relations elsewhere in San Jacinto Mountains. Fresh rock is white, and has bright-pink garnets that impart distinctive appearance. Grain size ranges from fine to coarse, with grain size varying on a small scale. Forms unmapped dikes and sills in adjacent metasedimentary rock (unit $\mathrm{ms}$ )

Ktlc Tonalite of Lamb Canyon (late Cretaceous) - Unit forms outcrops covered by rounded boulders, and consists of homogeneous white to light-gray, mediumto coarse-grained tonalite that is massive to slightly foliated and in most places contains large euhedral sphene crystals; some outcrops are biotitebearing, others contain both biotite and hornblende. Rock originally was described by Fraser (1931), and is part of Cretaceous San Jacinto intrusive complex described by Hill (1984, 1988; Hill and Silver, 1988; Hill and others, 1988). Zircon from rock at head of Lamb Canyon in adjacent Beaumont quadrangle has $\mathrm{Pb} / \mathrm{U}$ age of $94 \mathrm{Ma}$; sphene yields $\mathrm{Pb} / \mathrm{U}$ age of $92.8 \mathrm{Ma}$ (W. Premo, personal commun. to D.M. Morton, 2002)

Khg Heterogeneous granitic rocks (Cretaceous) - Heterogeneous mixture of granitic 
rocks containing abundant gneiss and schist. Granitic rocks range in composition from hornblende-rich tonalite to leucocratic tonalite and from potassium-feldspar free rocks to granodiorite. Most are medium grained, and have textures ranging from hypidiomorphic-granular to xenomorphicgranular. Some rocks are inequigranular, having mafic minerals slightly but distinctly finer grained than quartz and feldspar. Plagioclase is zoned, sodic to intermediate andesine ranging from 1 to $4 \mathrm{~mm}$ in length. Potassium feldspar is untwinned and microcline-twinned, anhedral and interstitial grains mostly under $2 \mathrm{~mm}$ in size. Quartz content generally less than $10 \%$ in most rocks; occurs as anhedral, strained, interstitial grains. Hornblende generally less abundant than biotite; subhedral to anhedral, irregular-shaped grains ranging in size from 0.3 to $2.5 \mathrm{~mm}$. Biotite occurs as plates and irregular poikilitic grains, some partly altered to chlorite. In leucocratic rocks, muscovite is sparse constituent $0.5 \mathrm{~mm}$ long, mostly intergrown with biotite. Accessory minerals include apatite, sphene, zircon, and magnetite-ilmenite. Most abundant nongranitic fraction of this unit is mesocratic, fine- to mediumgrained, massive to foliated mafic rock composed of about $50 \%$ hornblende and biotite. Rock is even grained, although locally contains porphyroblasts of plagioclase; white feldspar layers are widespread. Some of these leucocratic layers are oriented parallel to foliation in granitic rocks, some cut foliation at high angles, and some are ptygmatically folded

ms Metasedimentary rock (pre-Mesozoic) - Layered and foliated biotite-quartz gneiss associated with thin unmapped zones of white marble and quartzite; locally intermingled with unmapped dikes and sills of Granite of Mt. Eden (Kmeg)

Marble (pre-Mesozoic) - White to light gray, coarse-grained marble with minor pods of calc-silicate rock 


\section{References Cited}

Albright, L.B., 1997, Geochronology and vertebrate paleontology of the San Timoteo Badlands, southern California: Riverside, University of California, unpub. Ph.D. thesis, 328 p.

Albright, L.B., 1999, Magnetostratigraphy and biochronology of the San Timoteo Badlands, southern California, with implications for local Pliocene-Pleistocene tectonic and depositional patterns: Geological Society of America Bulletin, v. 111, p. 1265-1293.

Allen, C.R., 1957, San Andreas fault zone in San Gorgonio Pass, southern California: Geological Society of America Bulletin, v. 68, p. 319-350.

Arnold, R., 1918, Topography and fault system of the region of the San Jacinto earthquake: Seismological Society of America Bulletin, v. 8, p. 68-73.

Axelrod, D.I., 1937, A Pliocene flora from the Mt. Eden beds, southern California: Carnegie Institution of Washington, Publication 576, p. 125-184.

Bennett, R.A., Friedrich, A.M., and Furlong, K.P., 2004, Codependent histories of the San Andreas and San Jacinto fault zones from the inversion of fault displacement rates: Geology, v. 32, p. 961-964.

Berggren, W.A., Hilgen, F.J., Langereis, C.J., and others, 1995a, Late Neogene chronology: new perspectives in high-resolution stratigraphy: Geological Society of America Bulletin, v. 107, p. 12721287.

Berggren, W.A., Kent, D.V., Swisher, C.C., III, and Aubry, M-P., 1995b, A revised Cenozoic geochronology and chronostratigraphy, in Berggren, W.A., Kent, D.V., Aubry, M-P., and Hardenbol, J., eds., Geochronology, time scales and global stratigraphic correlation: Tulsa, Okla., Society of Economic Paleontologists and Mineralogists, Special Publication 54, p. 129-212.

Beyer, L.A., 1959, Geology of the vicinity of Mt. Eden, El Casco quadrangle, California: Riverside, University of California, unpub. B.S. thesis, scale 1:24,000, $23 \mathrm{p}$.

Blacet, P.M., 1960, Geology of the Lamb Canyon area, north of San Jacinto, California: Riverside, University of California, unpub. B.S. thesis, scale 1:12,000, $41 \mathrm{p}$.

Blakely, R.J., and Simpson, R.W., 1986, Approximating edges of source bodies from magnetic or gravity anomalies: Geophysics, v. 51, p. 1494-1498.

Bloyd, R.M., Jr., 1971, Underground storage of imported water in the San Gorgonio Pass area, southern California: Geological Survey Water Supply Paper 1999D, 37 p.

Bowen, D.Q., Richmond, G.M., Fullerton, D.S., Sibrava, V., Fulton, R.J., and Velichko, A.A., 1986, Correlation of Quaternary glaciations in the northern hemisphere, in Sibrava, V., Bowen, D.Q., and Richmond, G.M., eds., Quaternary glaciations in the northern hemisphere: Quaternary Science Reviews, v. 5, p. 509-510 (plus chart).

Bowles, J.E., 1984, Physical and geotechnical properties of soils (2d ed.): New York, McGraw-Hill Book Company, 578 p.

Bull, W.B., 1991, Geomorphic responses to climatic change: New York, Oxford University Press, 326 p.

Burnham, W.L., and Dutcher, L.C., 1960, Geology and ground-water hydrology of the RedlandsBeaumont area, California, with special reference to ground-water outflow: United States Department of the Interior Geological Survey_Ground Water Branch, Open-File Report, 352 p. [This important report is very difficult to obtain. A good-quality copy is archived with the San Bernardino Valley Municipal Water District, from whom copies can be obtained].

California Department of Water Resources, 1959, Appendix B-Geology of San Jacinto and Elsinore units, in Santa Ana River investigation: California Department of Water Resources Bulletin 15, Appendix B, p. 99-126.

California Geological Survey, 1995, Earthquake fault zones, El Casco quadrangle: State of California earthquake fault zones delineated in compliance with the Alquist-Priolo Earthquake Fault Zoning Act, scale 1:24,000. 
Cande, S.C., and Kent, D.V., 1995, Revised calibration of the geomagnetic polarity timescale for the Late Cretaceous and Cenozoic: Journal of Geophysical Research, v. 100, no. B4, p. 6093-6095.

Carena, S., and Yue, L., 2005, 3D Images of faults within the Crafton Hills Fault Zone from the June 16th, 2005, Yucaipa, California, Earthquake-Implications for the geometry of the San Andreas Fault: Eos, Transactions of the American Geophysical Union, 86 (52), Fall Meet. Suppl., Abstract T51D1366 (http://adsabs.harvard.edu/abs/2005AGUFM.T51D1366C).

CHJ Inc., 1988, Geotechnical evaluation of younger alluvium (Qal), Oak Valley Project, Riverside County, California, Job No. 88585-3: unpublished consulting report on file with Riverside County Planning Department.

CHJ Inc., 2004, Subsurface investigation of faulting, tentative Tract No. 30545 east of Singleton Road and Calimesa Boulevard, Calimesa, California: unpublished consulting report on file with Riverside County Planning Department, 29 p.

Cordell, Lindrith, and Grauch, V.J.S., 1985, Mapping basement magnetization zones from aeromagnetic data in the San Juan Basin, New Mexico, in Hinze, W.J., ed., The utility of regional gravity and magnetic anomaly maps: Tulsa, Okla., Society of Exploration Geophysicists, p. 181-192.

Crowell, J.C., 1981, An outline of the tectonic history of southeastern California, in Ernst, W.G., ed., The geotectonic development of California (Rubey Volume I): Englewood Cliffs, N.J., Prentice-Hall, Inc., p. 583-600.

Dorsey, R.J., 2002, Stratigraphic record of Pleistocene initiation and slip on the Coyote Creek Fault, lower Coyote Creek, southern California, in Barth, A., ed., Contributions to crustal evolution of the southwestern United States: Boulder, Colo., Geological Society of America Special Paper 365, p. 251-269.

Dudley, P.H., 1936, Physiographic history of a portion of the Perris block, southern California: Journal of Geology, v. 44, p. 358-378.

Eckis, R., 1934, South Coastal basin investigation-Geology and ground-water storage capacity of valley fill: California Department of Water Resources Bulletin 45, 273 p.

Ehlig, P.L., 1968, Causes of distribution of Pelona, Rand, and Orocopia Schist along the San Andreas and Garlock faults, in Dickinson, W.R., and Grantz, Arthur, eds., Proceedings of conference on geologic problems of San Andreas Fault system: Stanford University Publications in Geological Sciences, v. XI, p. 294-305.

Ehlig, P.L., 1981, Origin and tectonic history of the basement terrane of the San Gabriel Mountains, central Transverse Ranges, in Ernst, W.G., ed., The geotectonic development of California (Rubey Volume I): Englewood Cliffs, N.J., Prentice-Hall, Inc., p. 253-283.

Ehlig, P.L., 1982, The Vincent Thrust: its nature, paleogeographic reconstruction across the San Andreas Fault, and bearing on the evolution of the Transverse Ranges, in Fife, D.L., and Minch, J.A., eds., Geology and mineral wealth of the California Transverse Ranges: South Coast Geological Society Guidebook no. 10 (Mason Hill volume), p. 370-379.

English, H.D., 1953, The geology of the San Timoteo Badlands: Claremont, Calif., Pomona College, unpub. M.S. thesis, 159 p., scale 1:24,000.

Fett, J.D., 1968, Geophysical investigations of the San Jacinto Valley, Riverside County, California: Riverside, University of California, unpub. M.A. thesis, 75 p.

Fett, J.D., Hamilton, D.H., and Fleming, F.A., 1967, Continuing surface displacement along the Casa Loma and San Jacinto faults in San Jacinto Valley, Riverside County, California: Engineering Geology, v. 4, p. 22-32.

Fraser, D.M., 1931, Geology of San Jacinto Quadrangle south of San Gorgonio Pass: California Journal of Mines and Geology, v. 27, no. 4, p. 494-540. 
Frick, C., 1921, Extinct vertebrate faunas of the Badlands of Bautista Creek and San Timoteo Canon, southern California: Berkeley, University of California Publications in Geology, v. 12, no. 5, p. 277424.

Gradstein, Felix, Ogg, James, and Smith, Alan, eds., 2004, A geologic time scale 2004: Cambridge, U.K., Cambridge University Press, 589 p., 1 pl.

Grauch, V.J.S., and Cordell, Lindrith, 1987, Limitations of determining density or magnetic boundaries from the horizontal gradient of gravity or pseudogravity data: Geophysics, v. 52, no. 1, p. 118-121.

Hamlin, H., 1918, Earthquakes in southern California: Seismological Society of America Bulletin, v. 8, p. $20-24$.

Hauksson, E., 2000, Crustal structure and seismicity distribution adjacent to the Pacific and North America plate boundary in southern California: Journal of Geophysical Research, v. 105, p. 13,875$13,903$.

Hehn, V.N., MacFadden, B.J., Albright, L.B., and Woodburne, M.O., 1996, Magnetic polarity stratigraphy and possible differential tectonic rotation of the Miocene-Pliocene mammal-bearing San Timoteo Badlands, southern California: Earth and Planetary Science Letters, v. 141, p. 35-49.

HeisKanen, W.A., and Vening-Meinesz, F.A., 1958, The Earth and its gravity field: New York, McGraw-Hill Book Company, Inc., 470 p.

Henderson, L.H., 1939, Detailed geological mapping and fault studies of the San Jacinto tunnel line and vicinity: Journal of Geology, v. 47, no. 3, p. 314-324.

Hill, R.I., 1984, Petrology and petrogenesis of batholithic rocks, San Jacinto Mountains, southern California: Pasadena, California Institute of Technology, unpub. Ph.D. dissertation, 660 p.

Hill, R.I., 1988, San Jacinto intrusive complex: 1. Geology and mineral chemistry, and a model for intermittent recharge of tonalitic magma chambers: Journal of Geophysical Research, v. 93, no. B9, p. $10,325-10,348$.

Hill, R.I., and Silver, L.T., 1988, San Jacinto intrusive complex: 3. Constraints on crustal magma chamber processes from strontium isotope heterogeneity: Journal of Geophysical Research, v. 93, no. B9, p. 10,373-10,388.

Hill, R.I., Chappell, B.W., and Silver, L.T., 1988, San Jacinto intrusive complex: 2. Geochemistry: Journal of Geophysical Research, v. 93, no. B9, p. 10,349-10,372.

Hill, R.T., 1920, The rifts of southern California: Seismological Society of America Bulletin, v. 10 , no. 3, p. 146-149.

Hill, R.T., 1928, Southern California geology and Los Angeles earthquakes: Los Angeles, Southern California Academy of Sciences, $232 \mathrm{p}$.

Hopkins, D.M., 1975, Time-stratigraphic nomenclature for the Holocene Epoch: Geology, v. 3, p. 10.

Humphreys, E.D., and Hager, B.H., 1990, A kinematic model for the late Cenozoic development of southern California crust and upper mantle: Journal of Geophysical Research, v. 95, no. B12, p. 19,747-19,762.

Humphreys, E.D., and Weldon, R.J., II, 1994, Deformation across the western United States-A local estimate of Pacific-North American transform deformation: Journal of Geophysical Research, v. 99, p. 19,975-20,010.

Imbrie, J., Hays, J.D., Martinson, D.G., McIntyre, A., Mix, A.C., Morley, J.J., Pisias, N.G., Prell, W.L., and Shackleton, N.J., 1984, The orbital theory of Pleistocene climate-support from a revised chronology of the marine 180 record, in Berger, A., Imbrie, J., Hays, J., Kukla, G., and Saltzman, B., eds., Milankovitch and Climate, Part I: Dordrecht, Reidel Publishing Co., p. 269-305.

International Union of Geodesy and Geophysics, 1971, Geodetic Reference System 1967: International Association of Geodesy Special Publication no. 3, 116 p. 
Jachens, R.C., and Griscom, Andrew, 1985, An isostatic residual gravity map of California-A residual map for interpretation of anomalies from intracrustal sources, in Hinze, W.J., ed., The utility of regional gravity and magnetic maps: Tulsa, Okla., Society of Exploration Geophysicists, p. 347-360. Jahns, R.H., 1954, Geology of the Peninsular Range province, southern California and Baja California, in Jahns, R.H., ed., Geology of southern California: California Division of Mines Bulletin 170, of Chapter II, Geology of the natural provinces, p. 29-52

Kahle, J.E., 1987, The San Jacinto Fault Zone (the Claremont, Casa Loma, and related faults) in the Lakeview and El Casco quadrangles, Riverside County, California: California Division of Mines and Geology, Fault Evaluation Report FER-179, 9 p.

Kendrick, K.J., 1996, Descriptions and laboratory analysis for soils in the northern San Timoteo

Badlands, California: U.S. Geological Survey Open-File Report 96-93, 6 p.

Kendrick, K.J., 1999, Quaternary geologic evolution of the northern San Jacinto fault zone; Understanding evolving strike-slip faults through geomorphic and soil stratigraphic analysis: Riverside, University of California, unpub. Ph.D. dissertation, $301 \mathrm{p}$.

Kendrick, K.J., McFadden, L.D., and Morton, D.M., 1994, Soils and slip rates along the northern San Jacinto fault, in McGill, S.F., and Ross, T.M., eds., Geological investigations of an active margin: Geological Society of America Cordilleran Section Guidebook, Trip No. 8, p. 146-151.

Kendrick, K.J., Morton, D.M., Wells, S.G., and Simpson, R.W., 2002, Spatial and temporal deformation along the northern San Jacinto fault, southern California; implications for slip rates: Seismological Society of America Bulletin, v. 92, no. 7, p. 2782-2802.

Knecht, A.A., 1971, Soil survey of western Riverside County area, California: U.S. Department of Agriculture, Soil Conservation Service, 157 p., 214 pl., scale 1:24,000.

Langenheim, V.E., Chapman, R.H., Sikora, R.F., Ponce, D.A., and Dixon, E.T., 1991, Isostatic residual gravity map of the Santa Ana 1:100,000-scale quadrangle, California: U.S. Geological Survey OpenFile Report 91-555, scale 1:100,000.

Langenheim, V.E., and Hauksson, Egill, 2001, Comparison of crustal density and velocity variations in southern California: Geophysical Research Letters, v. 28, p. 3087-3090.

Langenheim, V.E., Jachens, R.C., Matti, J.C., Morton, D.M., Hauksson, E., and Christensen, A., 2005, Geophysical evidence for wedging in the San Gorgonio Pass structural knot, southern San Andreas Fault zone, southern California: Geological Society of America Bulletin, v. 117, p. 1554-1572; doi: 10.1130/B25760.1.

Langenheim, V.E., Jachens, R.C., Morton, D.M., Kistler, R.W., and Matti, J.C., 2004, Geophysical and isotopic mapping of preexisting structures that influenced the location and development of the San Jacinto fault zone, southern California: Geological Society of America Bulletin, v. 116, p. 1143-1157. Langenheim, V.E., Lee, T.C., Biehler, Shawn, Jachens, R.C., and Morton, D.M., 2006, Isostatic gravity map with geology of the Santa Ana 30' by 60' quadrangle, southern California: U.S. Geological Survey Scientific Investigations Map 2951, scale 1:100,000, 25 p., accessed at http://pubs.usgs.gov/sim/2006/2951/.

Larsen, N.R., 1962, Geology of the Lamb Canyon area, Beaumont, California: Claremont, California, Pomona College, unpub. M.S. thesis, 93 p., scale 1:12,000.

Lawson, A.C., and others, 1908, The California earthquake of April 18, 1906; Report of the State Earthquake Investigation Commission: Carnegie Institute of Washington Publication 87, 2 volumes, $452 \mathrm{p}$.

Lee, T-C., Biehler, S., Park, S.K., and Stephenson, W.J., 1996, A seismic refraction and reflection study across the central San Jacinto Basin, Southern California: Geophysics, v. 61, no. 5, p. 1258-1268.

Lofgren, B.E., 1976, Land subsidence and aquifer-system compaction in the San Jacinto Valley, Riverside County, California-A progress report: U.S. Geological Survey Journal of Research, v. 4, no. 1, p. 9-18. 
Lofgren, B.E., and Meyer, Rubin, 1975, Radiocarbon dates indicate rates of graben downfaulting, San Jacinto Valley, California: U.S. Geological Survey Journal of Research, v. 3, no. 1, p. 45-46.

Lundelius, E.L., Jr., Downs, T., Lindsay, E.H., Semken, H.A., Zakrewski, R.J., Churcher, C.S., Harington, C.R., Schultz, G.E., and Webb, S.D., 1987, The North American Quaternary sequence, in Woodburne, M.O., ed., Cenozoic mammals of North America-Geochronology and biostratigraphy: Berkeley and Los Angeles, University of California Press, p. 211-235.

MacLeod, N.S., 1961, Geology of the Mt. Eden area, California: Riverside, University of California, unpub. B.S. thesis., scale 1:12,000, 27 p.

Magistrale, H., Day, S., Clayton, R., and Graves, R., 2000, The SCEC southern California reference three-dimensional seismic velocity model version 2: Seismological Society of America Bulletin, v. 90, no. 6B, p. S65-S76.

Manson, M.W., Davenport, C.W., Brown, K.D., Wills, C.J., and Domrose, C.J., 2002, Landslides in the Highway 60 corridor, San Timoteo Badlands, Riverside County, California: California Geological Survey Special Report 186, 21 p.

Martinson, D.G., Pisias, N.G., Hays, J.D., Moore, T.C., and Shackleton, N.J., 1987, Age dating and the orbital theory of the ice ages-high resolution 0 to 300,000-year chronostratigraphy: Quaternary Research, v. 27, p. 1-29.

Matti, J.C., and Morton, D.M., 1975, Geologic history of the San Timoteo Badlands, southern California: Geological Society of America Abstracts with Programs, v. 7, no. 3, p. 344.

Matti, J.C., and Morton, D.M., 1993, Paleogeographic evolution of the San Andreas fault in southern California-a reconstruction based on a new cross-fault correlation, in Powell, R.E., Weldon, R.J., and Matti, J.C., eds., The San Andreas Fault system-displacement, palinspastic reconstruction, and geologic evolution: Geological Society of America Memoir 178, p. 107-159.

Matti, J.C., Morton, D.M., and Cox, B.F., 1985, Distribution and geologic relations of fault systems in the vicinity of the central Transverse Ranges, southern California: U.S. Geological Survey Open-File Report 85-365, 27 p., scale 1:250,000.

Matti, J.C., Morton, D.M., and Cox, B.F., 1992a, The San Andreas Fault system in the vicinity of the central Transverse Ranges province, southern California: U.S. Geological Survey Open-File Report 92-354, 40 p., scale 1:250,000.

Matti, J.C., Morton, D.M., Cox, B.F., Carson, S.E., and Yetter, T.J., 1992b, Geologic map of the Yucaipa 7.5' quadrangle, California: U.S. Geological Survey Open-File Report 92-446, 14 p., scale $1: 24,000$.

Matti, J.C., Morton, D.M., Cox, B.F., Carson, S.E., and Yetter, T.J., 2003a, Geologic map and digital database of the Yucaipa 7.5' quadrangle, San Bernardino and Riverside Counties, California, version 1.0: U.S. Geological Survey Open-File Report 03-301, scale 1:24,000.

Matti, J.C., Morton, D.M., Cox, B.F., and Kendrick, K.J., 2003b, Geologic map and digital database of the Redlands 7.5' quadrangle, San Bernardino and Riverside Counties, California, version 1.0: U.S. Geological Survey Open-File Report 03-302, scale 1:24,000.

May, S.R., and Repenning, C.A., 1982, New evidence for the age of the Mount Eden fauna, southern California: Journal of Vertebrate Paleontology, v. 2, no. 1, p. 109-113.

McFadden, L.D., 1982, The impacts of temporal and spatial climatic changes on alluvial soils genesis in southern California: Tucson, University of Arizona, unpub. Ph.D. thesis, 430 p.

Mendenhall, W.C., 1905, The hydrology of San Bernardino Valley, California: U.S. Geological Survey Water-Supply Paper 142, 124 p.

Michael, R.H., 1956, Geology of a portion of the San Timoteo Badlands, western Riverside County, California: Riverside, University of California, unpub. B.S. thesis, scale 1:12,000, $27 \mathrm{p}$.

Morelli, C., ed., 1974, The International Gravity Standardization Net, 1971: International Association of Geodesy Special Publication no. 4, 194 p. 
Morton, D.M., 1972, Geology of the Lakeview-Perris quadrangles, Riverside County, California: California Division of Mines and Geology Map Sheet 19, scale 1:24,000.

Morton, D.M., 1975, Synopsis of the geology of the eastern San Gabriel Mountains, southern California, in Crowell, J.C., ed., San Andreas fault in southern California: California Division of Mines and Geology Special Report 118, p. 170-176.

Morton, D.M., 1977, Surface deformation in part of the San Jacinto Valley, southern California: U.S. Geological Survey Journal of Research, v. 5, no. 1, p. 117-124.

Morton, D.M., 1978a, Geologic map of the San Bernardino South 7.5' quadrangle, California: U.S. Geological Survey Open-File Report 78-20, scale 1:24,000.

Morton, D.M., 1978b, Geologic map of the Redlands 7.5' quadrangle, California: U.S. Geological Survey Open-File Report 78-21, scale 1:24,000.

Morton, D.M., 1978c, Geologic map of the Sunnymead 7.5' quadrangle, California: U.S. Geological Survey Open-File Report 78-22, scale 1:24,000.

Morton, D.M., 1999, compiler, Preliminary digital geologic map of the Santa Ana 30' x 60' quadrangle, Southern California, version 1.0: U.S. Geological Survey Open-File Report 99-172, scale 1:100,000, accessed at http://pubs.usgs.gov/of/1999/of99-172/.

Morton, D.M., and Matti, J.C., 1987, The Cucamonga fault zone-Geologic setting and Quaternary history, in Morton, D.M., and Yerkes R.F., eds., Recent reverse faulting in the Transverse Ranges, California: U.S. Geological Survey Professional Paper 1339, p. 179-203, scale 1:24,000.

Morton, D.M., and Matti, J.C., 1989, A vanished late Pliocene to early Pleistocene alluvial-fan complex in the northern Perris block, southern California, in Colburn, I.P., Abbott, P.L., and Minch, John, eds., Conglomerates in basin analysis-a symposium dedicated to A.O. Woodford: Pacific Section, Society of Economic Paleontologists and Mineralogists, v. 62, p. 73-80.

Morton, D.M., and Matti, J.C., 1993, Extension and contraction within an evolving divergent strike-slip fault complex-the San Andreas and San Jacinto fault zones at their convergence in southern California, in Powell, R.E., Weldon, R.J., and Matti, J.C., eds., The San Andreas Fault systemdisplacement, palinspastic reconstruction, and geologic evolution: Geological Society of America Memoir 178, p. 217-230.

Morton, D.M., and Matti, J.C., 2001a, Geologic map of the Lakeview 7.5' quadrangle, Riverside County, California, Version 1.0: U.S. Geological Survey Open-File Report 01-174, scale 1:24,000. Morton, D.M., and Matti, J.C., 2001b, Geologic map of the Sunnymead 7.5' quadrangle, Riverside County, California: U.S. Geological Survey Open-File Report 01-450, scale 1:24,000, Version 1.0. Morton, D.M., and Miller, F.K., 2006, Geologic map of the Santa Ana and San Bernardino 30' x 60' quadrangles, California: U.S. Geological Survey Open-File Report 2006-1217, four map sheets, scale 1:100,000, accessed at http://pubs.usgs.gov/of/2006/1217/.

Morton, D.M., Matti, J.C., Miller, F.K., and Repenning, C.A., 1986, Pleistocene conglomerate from the San Timoteo Badlands, southern California; constraints on strike-slip displacements on the San Andreas fault: Geological Society of America Abstracts with Programs, v. 18, no. 2, p. 161.

Morton, D.M., Sadler, P.M., and Matti, J.C., 1990, Constant watershed growth and fault offset in the San Timoteo Badlands, southern California: Geological Society of America Abstracts with Programs, v. 22, no. 3, p. 70 .

Noble, L.F., 1926, The San Andreas rift and some other active faults in the desert region of southeastern California: Carnegie Institute of Washington Yearbook No. 25 (1925-1926), p. 415-435.

Noble, L.F., 1927, The San Andreas rift and some other active faults in the desert region of southeastern California: Seismological Society of America Bulletin, v. 17, p. 25-39.

Noble, L.F., 1932, The San Andreas rift in the desert region of southeastern California: Carnegie Institute of Washington Year Book 31, p. 355-363. 
North American Commission on Stratigraphic Nomenclature, 1983, North American stratigraphic code: American Association of Petroleum Geologists Bulletin, v. 67, no. 5, p. 841-875.

North American Geologic-map Data Model Science Language Technical Team, 2004, Report on progress to develop a North American science-language standard for digital geologic-map databases; Appendix C - Sedimentary materials: science language for their classification, description, and interpretation in digital geologic-map databases, Version 1.0 (12/18/2004), in Soller, D.R., ed., Digital Mapping Techniques '04-Workshop Proceedings: U.S. Geological Survey Open-File Report 20041451, 595 p. Appendix C accessed at http://pubs.usgs.gov/of/2004/1451/sltt/appendixC/.

Ogg, J.G., Ogg, Gabi, and Gradstein, F.M., 2008, The concise geologic time scale: Cambridge, U.K., Cambridge University Press, 177 p.

Park, S.K., Pendergraft, D., Stephenson, W.J., Shedlock, K.M., and Lee, T-C., 1995, Delineation of intrabasin structure in a dilational jog of the San Jacinto fault zone, southern California: Journal of Geophysical Research, v. 100, no. B1, p. 691-702.

Petra Consultants, 2004, Fault investigation, Oak Valley at Calimesa, Riverside County, California: unpublished consulting report on file with Riverside County Planning Department, 16 p., many appendices and map plates.

Phillips, F.M., Zreda, M.G., Smith, S.S., Elmore, D., Kubick, P.W., and Sharma, P., 1990, Cosmogenic chlorine-36 chronology for glacial deposits at Bloody Canyon, eastern Sierra Nevada: Science, v. 248, p. 1529-1532.

Pisias, N.G., Martinson, D.G., Moore, T.C., Jr., Shackleton, N.J., Prell, W., Hays, J., and Boden, G., 1984, High resolution stratigraphic correlation of benthic oxygen isotopic records spanning the last 300,000 years: Marine Geology, v. 56, p. 119-136.

Plouff, Donald, 1977, Preliminary documentation for a FORTRAN program to compute gravity terrain corrections based on topography digitized on a geographic grid: U.S. Geological Survey Open-File Report 77-535, $45 \mathrm{p}$.

Proctor, R.J., 1962, Geologic features of a section across the Casa Loma fault, exposed in an aqueduct trench near San Jacinto, California: Geological Society of America Bulletin, v. 73, p. 1293-1296.

Rasmussen, G.S., and Associates, 1988a, Engineering geology investigation tentative Tract 9209, Lots 1-337, San Bernardino County, California: unpublished consulting report on file with Riverside County Planning Department, $29 \mathrm{p}$.

Rasmussen, G.S., and Associates, 1988b, Preliminary engineering geology investigation, Oak Valley Project, 6725 acres southwest of Interstate 10, northern Riverside County, California; Project No. 2529.1, August 9, 1988: unpublished consulting report on file with Riverside County Planning Department, 36 p., with many figures.

Repenning, C.A., 1987, Biochronology of the microtine rodents of the United States, in Woodburne, M.O., ed., Cenozoic mammals of North America: Berkeley, University of California Press, p. 236268.

Rewis, D.L., Christensen, A.H., Matti, J.C., Hevesi, J.A., Nishikawa, T., and Martin, P.M., 2006, Geology, ground-water hydrology, geochemistry, and ground-water simulation of the Beaumont and Banning storage units, San Gorgonio Pass area, Riverside County, California: U.S. Geological Survey Scientific Investigations Report 2006-5026, 173 p.

Reynolds, R.E., and Reeder, W.A., 1986, Age and fossil assemblages of San Timoteo Formation, Riverside County, California, in Kooser, M.A., and Reynolds, R.E., eds., Geology around the margins of the eastern San Bernardino Mountains: Redlands, Calif., Publications of the Inland Geological Society, v. 1, p. 51-56.

Reynolds, R.E., and Reeder, W.A., 1991, The San Timoteo Formation, Riverside County, California: Redlands, Calif., San Bernardino County Museum Quarterly, v. 39, p. 44-48. 
Reynolds, R.E., Sample, Lloyd, and Conkling, Steven, 2013, The El Casco Substation Fauna and Flora, new records from the late Blancan North American land Mammal Age San Timoteo Formation, Riverside County, California: Society of Vertebrate Paleontology, Abstracts with Programs, 2013 annual meeting, p. 197.

Rogers, T.H., compiler, 1965, Santa Ana sheet of Geologic map of California: California Division of Mines and Geology, scale 1:250,000.

Rolfe, F., and Strong, A.M., 1918, The earthquake of April 21, 1918, in the San Jacinto Mountains: Seismological Society of America Bulletin, v. 8, p. 63.

Sanders, C.O., 1993, Interaction of the San Jacinto and San Andreas fault zones, southern Californiatriggered earthquake migration and coupled recurrence intervals: Science, v. 260, p. 973-976.

Sanders, C.O., and Kanamori, H., 1984, A seismotectonic analysis of the Anza seismic gap, San Jacinto fault zone, southern California: Journal of Geophysical Research, v. 89, no. B7, p. 5873-5890.

Sanders, C., and Magistrale, H., 1997, Segmentation of the northern San Jacinto fault zone, southern California: Journal of Geophysical Research, v. 102, no. B12, p. 27,453-27,467.

Savage, J.C., and Prescott, W.H., 1976, Strain accumulation on the San Jacinto fault near Riverside, California: Seismological Society of America Bulletin, v. 66, no. 5, p. 1749-1754.

Shackleton, N.J., Berger, A., and Peltier, W.R., 1990, An alternative astronomical calibration of the lower Pleistocene timescale based on ODP site 677: Transactions of the Royal Society of Edinburgh, Earth Science, v. 81, p. 251-261.

Sharp, R.V., 1967, San Jacinto fault zone in the Peninsular Ranges of southern California: Geological Society of America Bulletin, v. 78, p. 705-730.

Sharp, R.V., 1972, Map showing recently active breaks along the San Jacinto fault zone between the San Bernardino area and Borrego Valley, California: U.S. Geological Survey Miscellaneous Geologic Investigations Map I-675, scale 1:24,000.

Sharp, R.V., 1981, Variable rates of late Quaternary strike slip on the San Jacinto fault zone, southern California: Journal of Geophysical Research, v. 86, no. B3, p. 1754-1762.

Shuler, E.H., 1953, Geology of a portion of the San Timoteo Badlands near Beaumont, California: Los Angeles, University of Southern California, unpub. M.S. thesis, 106 p., scale 1:48,000.

Simpson, R.W., Jachens, R.C., Blakely, R.J., and Saltus, R.W., 1986, A new isostatic residual gravity map of the conterminous United States with a discussion on the significance of isostatic residual anomalies: Journal of Geophysical Research, v. 91, p. 8348-8372.

Smith, D.P., 1979, The San Gorgonio Pass Fault: California Division of Mines and Geology, Fault Evaluation Report FER-87, 7 p.

Telford, W.M., Geldart, L.O., Sheriff, R.E., and Keyes, D.A., 1976, Applied geophysics: New York, Cambridge University Press, 960 p.

Townley, S.D., 1918, The San Jacinto earthquake of April 21, 1918: Seismological Society of America Bulletin, v. 8, p. 45-67.

Treiman, J.A., 1994, The San Gorgonio Pass, Banning and related faults, Riverside County, California: California Division of Mines and Geology, Fault Evaluation Report FER-235, 47 p.

U.S. Geological Survey Geologic Names Committee, 2010, Divisions of geologic time - major chronostratigraphic and geochronologic units: U.S. Geological Survey Fact Sheet 2010-3059, 2. p.

Varnes, D.J., 1978, Slope movement types and processes, in Schuster, R.L., and Krizek, R.J., eds., Landslides-analysis and control: Washington, D.C., Transportation Research Board, National Academy of Sciences, Special Report 176, p. 11-33.

Vaughan, F.E., 1922, Geology of the San Bernardino Mountains north of San Gorgonio Pass: California University Publications in Geological Sciences, v. 13, p. 319-411.

Waring, G.A., 1919, Ground water in the San Jacinto and Temecula basins, California: U.S. Geological Survey Water Supply Paper 429, 113 p. 
Webster's Encyclopedic Unabridged Dictionary of the English Language, 2001: San Diego, Thunder Bay Press, 2230 p.

Weldon, R., and Humphreys, E., 1986, A kinematic model of southern California: Tectonics, v. 5, no. 1, p. 33-48.

Weldon, R.J., II, and Sieh, K.E., 1985, Holocene rate of slip and tentative recurrence interval for large earthquakes on the San Andreas fault, Cajon Pass, southern California: Geological Society of America Bulletin, v. 96, p. 793-812.

Willingham, R.C., 1981, Gravity anomaly patterns and fault interpretations in the San Bernardino Valley and western San Gorgonio Pass area, southern California, in Brown, A.R., and Ruff, R.W., eds., Geology of the San Jacinto Mountains: Santa Ana, California, South Coast Geological Society, Annual Field trip guidebook, no. 9, p. 164-174.

Woodruff, G.A., and Brock, W.Z., 1980, Soil survey of San Bernardino County, southwestern part, California: U.S. Department of Agriculture, Soil Conservation Service, 64 p., scale 1:24,000.

Woodward-Clyde Consultants, 1993, Feasibility-level geologic/geotechnical investigations for Upper Singleton Canon Reservoir, Riverside County, California: unpub. consultants' report, April 1993.

Young, A.A., Ewing, P.A., and Blaney, H.F., 1941, Utilization of the waters of Beaumont Plain and San Jacinto Basin, California: U.S. Department of Agriculture, 336 p. 


\section{Appendix 1}

\section{Boundary Between the San Timoteo and Mt. Eden Formations}

The sedimentary sequence in the San Timoteo Badlands first was examined by Frick (1921), who separated it into his "upper San Timoteo deposition" and "lower San Timoteo deposition" (Frick, 1921, p. 317, 335). To the upper part of the sequence Frick (1921, p. 283) applied the name San Timoteo formation; to the lower part he applied the name "Eden Formation" (although elsewhere in his report he referred to these as the "Eden beds"; Frick, 1921, p. 335). Frick's main focus was the classification of fossil vertebrates from the San Timoteo Badlands sequence. Accordingly, he did not make a detailed geologic map, nor did he designate type sections for his formational units or document their internal and lateral stratigraphic relations. From the outset, then, no solid foundation was established for lithostratigraphic classification of sedimentary materials in the San Timoteo Badlands.

Subsequent to Frick's work, stratigraphic interpretations in the San Timoteo Badlands have varied from worker to worker. In a report on rocks directly southeast of the El Casco quadrangle, Fraser (1931) mapped sedimentary materials in the lower part of the San Timoteo succession that Frick (1921) referred to as the "Eden formation" (our fig. 7). Graduate theses by English (1953), Shuler (1953), and Larsen (1962) examined the San Timoteo Badlands sequence in various parts of its outcrop belt, and undergraduate reports by Beyer (1959), Blacet (1960), and MacLeod (1961) examined structural and stratigraphic relations in the Mt. Eden area. Matti and Morton (1975) discussed the general stratigraphy and depositional history of the San Timoteo sequence, and May and Repenning (1982) brought a modern perspective to vertebrate-fossil collections described by Frick (1921) from the lower part of the sequence in the Mt. Eden area. Reynolds and Reeder $(1986,1991)$ summarized paleontologic and stratigraphic aspects of the upper part of the sequence (northwest of the El Casco quadrangle). Matti and Morton (1993) evaluated regional paleogeographic relations of the San Timoteo sequence in the context of the San Andreas Fault system. Albright $(1997,1999)$ conducted a comprehensive analysis of the vertebrate paleontology of the Badlands succession, and placed the fossil assemblages within a magnetostratigraphic context (also see Hehn and others, 1996).

Despite these many investigations, a type section and formal stratigraphic names have not been documented for sedimentary units in the Badlands sequence. Moreover, previous workers have offered conflicting interpretations of stratigraphic relations among these units and internally within them. Although we have tried to clarify stratigraphic relations in the El Casco quadrangle, we still use all stratigraphic nomenclature informally.

Our mapping in the quadrangle and in the adjacent Beaumont, San Jacinto, and Lakeview quadrangles leads to nomenclature and stratigraphic relations indicated in figures 7 and 8 . This scheme recognizes two major stratigraphic packages - the San Timoteo formation [revised] and the Mt. Eden formation [revised], each having unique lithologic features, depositional histories, and sediment provenances. Our usage conforms to that of some previous workers but departs from that of others, especially with regard to the boundary between the Mt. Eden formation and overlying San Timoteo formation.

\section{General Statement}

Nearly every worker has interpreted stratigraphic relations between the San Timoteo and Mt. Eden formations differently (fig. 7; Frick, 1921; Fraser, 1931; English, 1953; Shuler, 1953; Beyer, 1959; Blacet, 1960; MacLeod, 1961; Larsen, 1962; Matti and Morton, 1975; Albright, 1997, 1999). Figures 22 and 23 of this report illustrate the boundary interval (although those outcrops are in the Beaumont 7.5' quadrangle, a few kilometers east of the Mt. Eden type area). Variable stratigraphic usage stems from several factors: (1) Frick's original lithologic and stratigraphic descriptions are generalized, and use 
early $20^{\text {th }}$ Century terminology and writing style that are archaic. Hence, his original stratigraphic interpretations are not always clear. (2) Geologic relations in the Mt. Eden area are complex due to faulting and facies changes. (3) Stratigraphic relations in the Mt. Eden area are obscured by landslides and, until recent wildfires, have been concealed by vegetation. (4) Prior to our work, no investigator had mapped the entire outcrop belt relevant to relations between the two formations.

Boundary relations between the San Timoteo and Mt. Eden formations are important for three reasons: (1) the two units are key lithostratigraphic components of the upper Cenozoic rock record in this part of southern California, and simply from a documentary perspective their mutual stratigraphic relations in their type area should be clarified. (2) The stratigraphic framework is important to the biostratigraphy of fossil vertebrates in the late Cenozoic land-mammal chronology (May and Repenning, 1982; Albright, 1997, 1999). (3) The two units record important paleogeographic changes in the late Cenozoic landscape of southern California. Because the contact between the two formations historically has been controversial, and because geologic relations are not explicitly revealing in the Mt. Eden type area, we discuss the boundary relations in some detail and provide support for our stratigraphic interpretations. Our conclusions are based on our mapping in the southeastern El Casco quadrangle and in the adjacent Beaumont and Lakeview quadrangles (Matti and others, unpub. geologic mapping; Morton and Matti, 2001).

\section{The Problem}

The boundary interval between the Mt. Eden and San Timoteo formations is not easy to interpret. Not only are stratigraphic relations in the Mt. Eden area complicated by faulting and by poor exposures, but relations here appear to be somewhat different from those in the Laborde Canyon area to the southeast. There, the stratigraphic succession is laid out a little more clearly, and led us to reevaluate how boundary relations traditionally have been interpreted in the Mt. Eden type area a few kilometers to the west.

Specifically at issue is the formational assignment of two stratigraphic intervals that occur in both the Laborde Canyon area and the Mt. Eden area, but with seemingly contradictory implications (fig. 7): (1) a homogeneous interval of greenish-gray slope-forming mudrock (dark-green unit in fig. 7), and (2) an interval of ripple-laminated sandstone and interlayered mudrock that is exposed best in roadcuts of Jackrabbit Trail (fig. 18).

\section{Laborde Canyon Succession}

In the southeast corner of the El Casco quadrangle, exposures in the Laborde Canyon area unambiguously span the boundary interval between the San Timoteo and Mt. Eden formations. Although traversed by strands of the Laborde Canyon Fault zone and affected by the San Timoteo Anticline, the stratal succession traced northward (upsection) from lower Laborde Canyon clearly displays the following stratigraphic elements (figs. 7, 8):

1. Oldest rocks are a thick sequence of white- and light-gray arkosic and lithic sandy rock and sandy conglomeratic rock that can be mapped northward from the Lakeview quadrangle (Morton and Matti, 2001, their unit "Tmea") into the El Casco quadrangle. Locally, the arkosic and lithic sequence contains mappable bodies of monolithologic conglomerate containing clasts of tonalitic rock (unit Tmeb). Without doubt, all of these lithologies in lower Laborde Canyon occur within a stratigraphic interval that Frick (1921) envisioned as his "Eden formation". In its type area, the arkosic and lithic materials are recognizable at various levels of the Mt. Eden formation, although mainly in its lower part. To the southeast and east they can be mapped into coeval reddish deposits that Frick (1921, p. 338-339) included within his "Potrero Creek deposits" and Frasier (1931, p. 511-512) included within 
his "Red Bed member of the Mt. Eden formation". Morton and Matti (2001) lumped these reddish lithologies within their conglomeratic sandstone member of the Mt. Eden formation (their unit "Tmec").

2. Abruptly overlying arkosic and lithic rocks of unit Tmea is a homogeneous mappable interval of greenish-gray, slope-forming mudrock (fig. 7, right side of figure).

3. The mudrock interval is succeeded by a mappable interval of ledge-forming beds of ripplelaminated and convolute-laminated sandstone interlayered with slope-forming mudrock like that of interval (2) (figs. 7, 8).

4. Upsection is a thick sequence of homogeneous sandy rock and minor conglomeratic rock indisputably assignable to the sandstone unit of the San Timoteo formation (unit Tstls).

5. Higher still in the section, a tongue of greenish-gray mudstone (unit Tstlf) projects westward and pinches out within sandy rock of the lower San Timoteo member (figs. 7, 8). This tongue thickens eastward into the Beaumont quadrangle, and there forms a thick body that clearly interfingers with the lower member (Matti and others, unpub. geologic mapping).

These stratigraphic relations can be mapped westward from Laborde Canyon toward the Mt. Eden area, where Frick (1921) originally defined his "San Timoteo formation" and "Eden formation". However, before they reach the Mt. Eden area, stratigraphic units in Laborde Canyon become enmeshed in north-dipping moderate-angle normal faults of the Laborde Canyon Fault zone (figs. 36, 37). Downto-the-north displacements within this zone sliver the stratigraphic section, juxtapose the lower member of the San Timoteo formation (unit Tstls) against arkosic and lithic rocks of the Mt. Eden formation (unit Tmea), and truncate some of the lithologic units laid out so clearly in Laborde Canyon-especially lithologic elements (2) and (3) above. West of Mt. Eden, in the vicinity of Jackrabbit Trail, elements (2) and (3) of Laborde Canyon reappear, but the directly underlying stratigraphic sequence contains some new lithologies not present in Laborde Canyon. As discussed below, these new lithologies in the Mt. Eden type area (our unit Tmeh, figs. 24 and 25) are those that create problems for lithostratigraphic correlation of the upper Cenozoic succession, and have led to inconsistent placement of the boundary between the San Timoteo and Mt Eden formations.

In Laborde Canyon, we adopt the following lithostratigraphic classification (fig. 7, right-hand side):

1. Below the mappable body of greenish-gray slope-forming mudstone (element 2, above), all arkosic and lithic sedimentary rocks and boulder conglomerate (element 1, above) clearly belong within the Mt. Eden formation of Frick (1921). We assign these to the arkosic and lithic member of the formation (unit Tmea) and to the boulder conglomerate member (unit Tmeb) (figs. 7, 8).

2. The mappable body of greenish-gray mudrock (element 5, above) that occurs high in the Laborde Canyon sequence indisputably interfingers with Frick's "San Timoteo beds" (element 4, above). We map this mudrock interval as a tongue of our fine-grained unit of the San Timoteo formation (unit Tstlf) that pinches out westward within the sandstone unit of the formation (unit Tstls) (fig. 8).

3. Mudrock that occurs lower in the section in Laborde Canyon-first as the mappable mudrock body (element 2, above) resting abruptly on arkosic and lithic rock of the Mt. Eden formation, and second as mudrock interbeds within the interval of ripple-laminated and convolute-laminated sandstone (element 3, above) - is identical in all respects to the mudrock tongue (element 5, above) that we map as the fine-grained unit of the San Timoteo formation (unit Tstlf). For this reason, we conclude that all greenish-gray mudstone in the Laborde Canyon sequence logically belongs within the San Timoteo depositional cycle, 
including mudrocks of element (2) and those that occur as interbeds in element (3). Accordingly, we classify elements 2 and 3 as mappable subunits of the San Timoteo formation - that is, our fine-grained unit (unit Tstlf) and our ripple-laminated unit (unit Tstlr), respectively. This conclusion independently was reached by Larsen (1962), who also included elements 2 and 3 at Laborde Canyon within the lower part of his San Timoteo formation (our fig. 7).

\section{Mt. Eden-Jackrabbit Trail Succession}

The stratigraphic succession in the Mt. Eden-Jackrabbit Trail area has elements in common with the Laborde Canyon area, but also has differences.

Similarities between the two areas include:

1. Adjacent to the Mt. Eden massif and in the core of the San Timoteo Anticline along Jackrabbit Trail, older stratigraphic levels consist of arkosic and lithic sandstone and conglomeratic sandstone (figs. 25, 26, 27, 28 29, 30) that, except for browner coloration, are similar to arkosic and lithic rock in lower Laborde Canyon that Frick (1921) and all other workers identify as Mt. Eden formation.

2. North and south of the Mt. Eden massif and along Jackrabbit Trail occur light-colored sandstone and conglomeratic sandstone that Frick (1921) and all workers indisputably identify as San Timoteo formation (fig. 16).

3. Intervening between these two map units are two distinctive lithologic sequences: an interval of greenish-gray mudrock (fig. 24, similar to element [2] at Laborde Canyon) overlain by ripple-laminated and convolute-laminated sandstone and interbedded greenish-gray mudrock (fig. 18, similar to element [3] at Laborde Canyon). Lithostratigraphic assignment of these two intervals has been equivocal.

Differences between the Mt. Eden and Laborde Canyon successions include the following:

1. In the Mt. Eden-Jackrabbit Trail area, the interval of greenish-gray mudrock contains coarser grained silty, sandy, and conglomeratic rock and (especially) layers of white limestone not present in the Laborde Canyon succession (figs. 24, 25, 26). These do not occur in the Laborde Canyon section.

2. The mudrock succession in the Mt. Eden-Jackrabbit Trail area appears to be thinner than in the Laborde Canyon area.

3. At Jackrabbit Trail, contact relations between the ripple-laminated unit and the overlying sandstone-dominated unit are not exposed clearly. Moreover, on the north side of Mt. Eden proper, the ripple-laminated unit is not present: instead, rocks typical of the San Timoteo formation (fig. 27) are juxtaposed directly against typical Mt. Eden formation (of Frick, 1921) by the Laborde Canyon Fault zone (discussed below). Frick (1921, p. 335) observed this relation where he states that his fossiliferous Eden ledges "to the immediate east [of his Mt. Eden fossil pits]*** disappear in the neighborhood of an overreaching arm of the San Timoteo formation". However, Frick attributed this convergence to stratigraphic overlap between the two units.

At issue in the Mt. Eden-Jackrabbit Trail area is the appropriate stratigraphic assignment for (a) the unit of ripple-laminated sandstone and greenish-gray mudstone interbeds (fig. 18) and (b) underlying intervals of greenish-gray mudrock (fig. 24). Although Frick (1921) did not indicate a specific contact between the San Timoteo and Mt. Eden formations, his stratigraphic intent can be determined from his 
text: he clearly included both lithologic sequences (mudrock interval and ripple-laminated interval) within his "Eden formation".

Ripple-laminated unit: Where he discusses lithologies within the formation, Frick (1921, p. 335336) states that, in the Eden Hot Spring area,

“*** a forty foot ledge of dark indurated sandstone in the 150 -foot cliff in the hillside opposite the northwest corner of Eden" occurs again "above the blue Eden shales in the Rabbit Cut grade [Jackrabbit Trail]".

We interpret this sentence to refer to our unit of ripple-laminated sandstone (for example, Frick, 1921, pl. 44, fig. 3). We have not been able to duplicate Frick's observation that this unit occurs as a "forty foot ledge of dark indurated sandstone in the 150-foot cliff in the hillside opposite the northwest corner of Eden". We suspect that he miscorrelated the two sequences. Like Frick, English (1953, p. 49, and figs. 17 and 18) included the ripple-laminated unit within the Mt. Eden interval; however, Shuler (1953, p. 35, 42, figs. 11, 13) included it within the San Timoteo formation.

At Jackrabbit Trail, the ripple-laminated interval clearly intervenes as a distinct unit between unambiguous San Timoteo formation (above) and unambiguous Mt. Eden formation (below). Many workers include the interval here within the Mt. Eden formation because of its greenish-gray mudrock interbeds that ostensibly are similar to mudrock in underlying intervals. However, there is no reason to support this interpretation, especially given the significant textural and fabric differences between the ripple-laminated sandstone beds here and the texturally and compositionally immature sandy and conglomeratic rocks typical of the Mt. Eden formation. We place the unit within the San Timoteo formation (our unit Tstlr) based on lithologic factors described above and based on correlation with the Laborde Canyon succession, where the ripple-laminated unit appears to fit better within the San Timoteo formation than it does the Mt. Eden formation (fig. 7).

Greenish-gray mudrock: Stratigraphic assignment of Frick's “blue Eden shales” is more problematic. Greenish-gray mudrock occurs on the north slopes of Mt. Eden, where Frick collected most of his vertebrate fossils (Frick, 1921, p. 282, locality 12; p. 339, University of California locality 3269). There, Frick describes the Mt. Eden sequence:

“*** faulted ledges of indurated Eden sands and shales intermixed in lower planes with limestone breccia rest against the metamorphic limestone of the basement complex. These ledges have yielded much of the best [fossil] material. They extend a fifth of a mile along the mountain face, and are capped by bluish shale slopes, thickly grown with brush (Frick, 1921, p. 335).

On the north slope of Mt. Eden, this interval clearly lies within the Mt. Eden formation. Despite jostling by landslides and by faults, the "bluish shale slopes" and associated white freshwater limestones can be extended intermittently west to the Jackrabbit Trail area, where the sequence is exposed in roadcuts (for example, near the $21^{\circ}$ northwest-dipping attitude about $150 \mathrm{~m}$ north of where the San Timoteo Anticline axis crosses Jackrabbit Trail). Previous workers in the Mt. Eden area usually follow Frick by including all "blue Eden shales" within the Mt. Eden formation-including those exposed along Jackrabbit Trail (fig. 24; English, 1953, p. 49; Shuler, 1953, p. 35, 42, figs. 11, 13; Albright, 1997 , 1999).

We favor a different stratigraphic interpretation. Like Frick (1921), English (1953), Shuler (1953), and Albright (1997, 1999), we concur that, on the north slopes of Mt. Eden (NE quarter of Sec. 23, (T. 3 S., R. 2 W.) and in low ground directly west of Eden Hot Springs, the Mt. Eden interval includes greenish-gray mudstone interbedded with arkosic sandstone and white limestone. We place these outcrops in our heterogeneous member of the Mt. Eden formation (unit Tmeh). However, at Jackrabbit Trail we depart from earlier workers and conclude that the interval of greenish-gray mudrock that superficially resembles Frick's "bluish Eden shales" can be separated into two map units - a lower 
one appropriately grouped within the Mt. Eden formation and an upper one more appropriately grouped within the San Timoteo formation (fig. 7, light-green and dark-green units, respectively). The upper unit can be mapped with difficulty eastward toward Eden Hot Springs, but it does not occur there or on the north slope of Mt. Eden because it is cut out by faults related to the Laborde Canyon Fault zone.

Distinction between two greenish-gray mudrock units is not easy, but we believe they can be defended and distinguished based on the following criteria:

1. Mudrock that occurs within our heterogeneous member of the Mt. Eden formation everywhere is associated with other nonmudrock lithologies. These include white limestones but also arkosic and lithic rocks that are sandy to conglomeratic and contain clasts of Peninsular Ranges-type basement rock. Although faulting observable in roadcuts of Jackrabbit Trail locally complicates this package, it clearly contains lithologies that occur on the north face of Mt. Eden, and it coincides with Frick's concept of his type Mt. Eden formation. All other workers reach this same conclusion. We include these beds (fig. 7, light-green unit) within our heterogeneous member of the formation, unit Tmeh.

2. Along Jackrabbit Trail directly beneath the ripple-laminated unit, a thin interval of monolithologic, light greenish-gray, slope-forming mudstone consists almost entirely of mudrock: it lacks limestone and coarser arkosic and lithic rock (dark-green interval in fig. 7). Thus, it differs from the heterogeneous member and more closely resembles the homogeneous mudrock interval at Laborde Canyon (where the heterogeneous interval is missing; see right-hand columnar section in fig. 7). Superficially, the homogeneous mudrock interval at Jackrabbit Trail resemble Frick's "Eden shales", and all previous workers correlate it with the "*** bluish shale slopes, thickly grown with brush***" that Frick (1921, p. 335) reports capping his fossiliferous "Eden ledges" on the north slope of Mt. Eden. We believe this correlation to be not valid.

When the Jackrabbit Trail succession is compared with the Laborde Canyon succession, the homogeneous greenish-gray mudrock interval at Jackrabbit Trail (fig. 7, dark-green interval) correlates well with the homogeneous mudrock interval at Laborde Canyon. Assuming they are the same lithostratigraphic unit, our treatment of the monolithologic mudstone sequence at Jackrabbit Trail and at Laborde Canyon needs to be consistent. Accordingly, in both areas we place the homogeneous mudrock interval in the San Timoteo formation (unit Tstlf).

Magnetostratigraphic evidence is consistent with a physical break in the mudrock succession at Jackrabbit Trail. Albright (1999, p. 1274) indicates that the magnetostratigraphic record from the homogeneous mudrock unit is missing an interval found elsewhere in the Eden Hot Springs composite magnetostratigraphy. The missing chronology includes Albright's reversed intervals R3 and R4 and an intervening normal interval N4 (Albright, 1999, fig. 8, samples 143 to 143a); this gap coincides approximately to intervals $\mathrm{C} 3 n .2 n-C 3 n .2 r$ and $\mathrm{C} 3 n .3 n-C 3 n .3 r$ in the lower part of the Gilbert Chron of the global magnetic polarity time scale (Albright, 1999, fig. 12). Although Albright (1999) considers elimination by faulting as the most likely explanation for the missing record, an unconformity within the homogeneous mudrock interval is equally likely. We favor this hypothesis. Throughout the Mt. Eden area the homogeneous mudrock interval appears to have a discontinuous, lenticular map pattern, as though the unit were pinching out locally on top of an irregular surface. This discontinuous geometry is consistent with sediment lapping over an irregular subaerial surface, with an unconformity at the position of the magnetostratigraphic gap recognized by Albright (1999). 


\section{Summary of Lithostratigraphic Revisions}

The boundary interval between the Mt. Eden and San Timoteo formations in the Laborde Canyon area is better exposed and more straightforward than in the traditionally cited reference sections in the Mt. Eden area that Frick (1921) used when he named the two formations and specified their mutual boundaries. In both areas, we map an interval of slope-forming greenish-gray mudstone directly beneath a ripple-laminated sandstone unit as a basal member of the San Timoteo formation, rather than as an uppermost member of the Mt. Eden formation. This decision is more easily defended in the Laborde Canyon area, because strata of the Mt. Eden formation directly beneath the mudstone are very different from any overlying lithologies; by contrast, in the Mt. Eden-Jackrabbit Trail area the uppermost Mt. Eden formation (our heterogeneous member) consists of greenish-gray lithologies that, in some respects, are similar to those we herein include within the San Timoteo formation. This superficial similarity is what has led to variable stratigraphic interpretation ever since Frick (1921) first named the two formations. 